\title{
CLOTH FILTER FOR DISASTER RELIEF WATER TREATMENT
}

\author{
A Thesis presented to \\ the Faculty of California Polytechnic State University \\ San Luis Obispo
}

In Partial Fulfillment
of the Requirements for the Degree of
Master of Science in Civil and Environmental Engineering

by

Shasta Le'ja Billings

March 2013 
(C) 2013

Shasta Le'ja Billings

ALL RIGHTS RESERVED 


\section{COMMITTEE MEMBERSHIP}

TITLE:

AUTHOR:

DATE SUBMITTED: $\quad$ March 2013

COMMITTEE CHAIR: Dr. Tryg Lundquist, Ph.D., Associate Professor Civil and Environmental Engineering Department Cal Poly, San Luis Obispo

COMMITTEE MEMBER: Dr. Yarrow Nelson, Ph.D., Professor Civil and Environmental Engineering Department Cal Poly, San Luis Obispo

COMMITTEE MEMBER: Dr. Shikha Rahman, Ph.D., Associate Professor Civil and Environmental Engineering Department Cal Poly, San Luis Obispo 


\section{ABSTRACT \\ Cloth Filter for Disaster Relief Water Treatment \\ Shasta Le'ja Billings}

Relief organizations and governments strive to provide safe drinking water to natural disaster survivors as quickly as possible. However, drinking water is typically provided either as bottled water or via mobile water treatment equipment, both of which can be difficult or expensive to transport rapidly into disaster zones. An alternative is the waterbag point-of-use treatment device developed at Cal Poly that allows survivors to produce safe drinking water from contaminated local sources. The waterbag is a $10-\mathrm{L}$ bladder designed for use with Procter \& Gamble Purifier of Water (PŪR $\left.{ }^{\circledR}\right)$ sachets, which contain coagulant and chlorine compounds. Following treatment with PŪR ${ }^{\circledR}$, treated water in the waterbag is flowed through an outlet port to a filter, primarily for parasitic cyst removal. Currently, the commercial version of the waterbag uses an effective but expensive hollow-fiber membrane microfilter ( $>\$ 10$ each). This cost will likely decrease the use of the waterbag by relief organizations responding to large disasters. The goal of the present thesis research was to develop a novel, low cost $(\sim 5)$, effective, low-profile filter to be used with the waterbag in large-scale disaster relief. This new filter is referred to as an envelope filter due to its geometry and size.

Various prototype envelope filters were constructed using layers of nonwoven polypropylene filter cloth. Two types of cloth were used: a nominally-rated $1-\mu \mathrm{m}$ pore size cloth and an absolute-rated 1- $\mu \mathrm{m}$ cloth. The filters tested were both internal and external to the waterbag and of various geometries. Filters were attached to the waterbag and used to filter defined test water after it had been treated with a PŪR ${ }^{\circledR}$ sachet. Test 
water for design experiments consisted of tap water with addition of standard dust (to increase turbidity) and seasalts (to increase salinity). In addition to this basic test water, mock U.S. EPA Challenge Water \#2 with added bacteria and cyst surrogates (fluorescent microspheres) was used to evaluate the filter prototype designs prior to testing according to U.S. EPA Guide Standard and Protocol for Testing Microbiological Water Purifiers in a commercial laboratory.

The filter design and mock challenge experiment results indicated that a 2-ply filter with one nominal and one absolute layer was the optimal filter design. In the mock U.S. EPA challenge tests, a flowrate of $20 \mathrm{~mL} / \mathrm{min}$ allowed this filter met the turbidity, bacteria, and microsphere removal requirements determined by the WHO and The Sphere Project for emergency drinking water treatment as well as the U.S. EPA Guide Standard and Protocol for Testing Microbiological Water Purifiers.. This filter design was further tested using the U.S. EPA Challenge Water \#2 with triplicate waterbags at the U.S. EPAcertified BioVir Laboratories in Benicia, Calif. All three waterbags with envelope filters met the recommendations for turbidity $(<5 \mathrm{NTU})$ and for virus removal ( $>4-\log$ removal). Two of the three waterbags met the bacteria and microsphere removal requirements $(>6-$ and $>3-\log$ removal, respectively). The failure of one of the prototypes to meet the requirements could have been due to improper setting of valve that throttled the flowrate through the filter or due to a slightly leaking hose pinch valve. Future work should include incorporating more reliable valves and improving the envelope filter design and materials to achieve higher allowable flowrates.

Keywords: cloth filter, disaster relief, water treatment 


\section{ACKNOWLEDGMENTS}

I would like to extend my sincere gratitude towards the following individuals for their knowledge and support:

Cal Poly Thesis Advisers: Dr. Tryg Lundquist, Dr. Yarrow Nelson, and Dr. Shikha

Rahman, for their encouragement and insight with this project and for the knowledge imparted from numerous classes together.

The two prior waterbag project graduate students who provided information and advice during my work: Tricia Compas-Markman and Margaret Dutton (Herzog)

Cal Poly Undergraduate Assistants: My official assistants, Chad Boggess and Sarah Kuehn, for all their dedicated help and for bearing with me through all the experiments, and my unofficial assistants, Kenzie Billings and Owen Beck, for coming to my aid in a moment's notice and for company during all those late nights in the lab.

Cal Poly Graduate Students: Brant Haflich, Kyle Fooks, Neal Adler, Sean Thomson, and Ankita Kashyap for their help with my experiments, teaching me about the secrets of the lab, as well as their encouragement and company during hours in the lab.

Colleagues at the Water Board: Thea Tryon, Diane Kukol, Kristina Seley, and John Rohrbough for their understanding and words of encouragement, and especially Howard Kolb, for his inspiring words and for never letting me lose sight of the light at the end of the tunnel.

Family: My Mom, Dad, and sister, Kenzie Billings, for their support, encouragement, advice, insight, and editing support.

Professional Advisers: Tricia Compas (DayOne Response, Inc.), Doug Gandy (Rosedale Products), and Dr. Richard E Danielson (BioVir Laboratories)

Cal Poly Professors and Staff: Lily Laiho, Jeff Reimer, and Alice Hamrick

Cal Poly Research and Graduate Programs: Jim Dunning and Susan Opava

This project was entirely funded by a grant from the U.S. Office of Naval Research through the Cal Poly C3RP program. I sincerely thank the Navy for their financial support of this project. 


\section{TABLE OF CONTENTS}

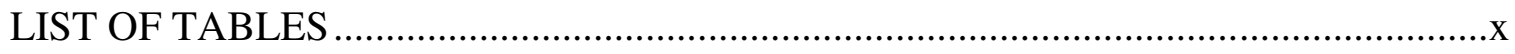

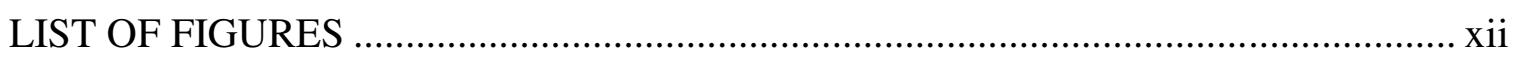

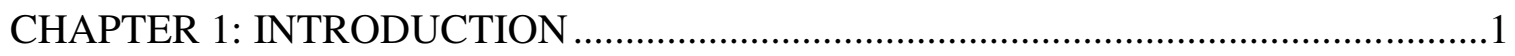

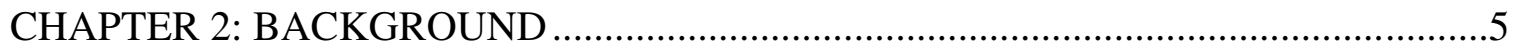

2.1 Drinking Water Contamination during Emergencies...........................................5

2.2 U.S. EPA Guide Standard and Protocol for Testing Microbiological Water

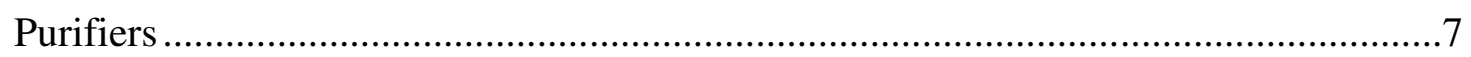

2.3 Filtration Mechanism and Technologies .........................................................

2.3.1 Hydraulic Loading ............................................................................ 10

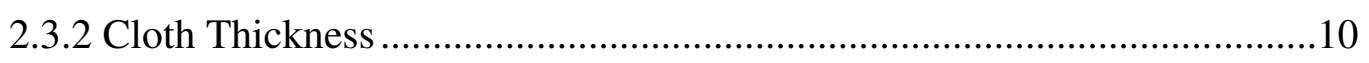

2.3.3 Cake Formation/Ripening/Dirt Breakthrough ...........................................10

2.3.4 Particle Characteristics ..............................................................................11

2.3.5 Nonwoven Filter Material ...................................................................12

2.3.6 Point-of-Use Filtration Technologies .........................................................13

CHAPTER 3: MATERIALS AND METHODS …………………….......................18

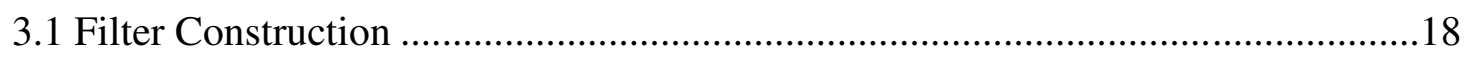

3.1.1 Materials Used for Filter Construction...................................................18

3.1.2 Construction of 2-ply Nominal-Absolute Filter (tested at BioVir

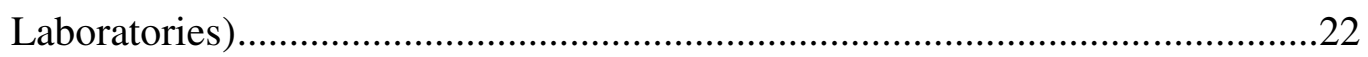

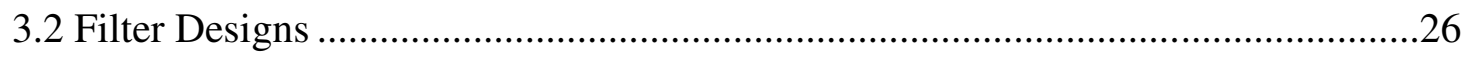

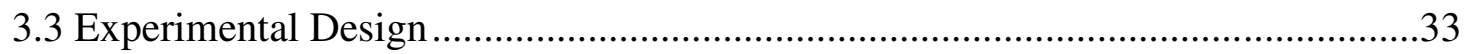

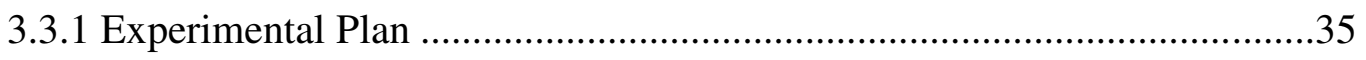

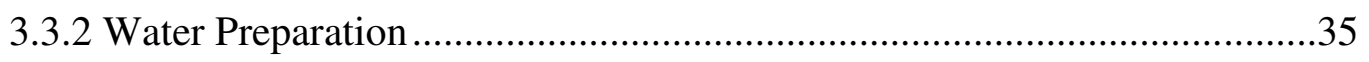

3.3.3 Experimental Testing Procedures ............................................................38

3.4 Water Quality Measurements.............................................................................40

3.4.1 Non-Microbiological Variables ................................................................40

3.4.2 Microbiological Variables ...........................................................................

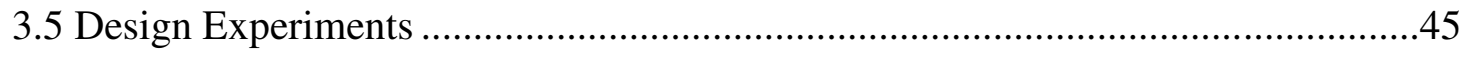

3.5.1 Water Preparation for Design Experiments ................................................46 
3.5.2 Experimental Procedures for Design Experiments......................................48

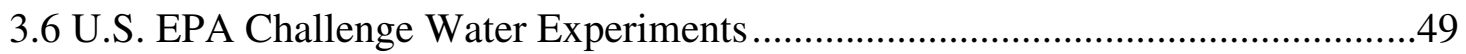

3.6.1 Water Preparation for Mock Challenge Water Experiments.......................50

3.6.2 Experimental Procedure for Mock Challenge Water Experiments ..............52

3.6.3 Water Preparation at BioVir for Official Challenge Water

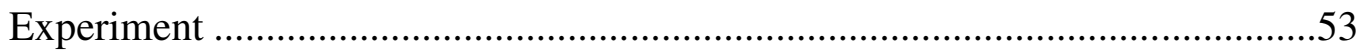

3.6.4 Experimental Procedure at BioVir for Official Challenge Water

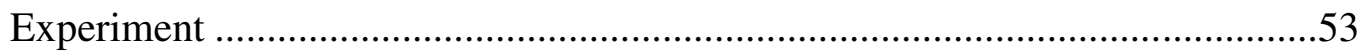

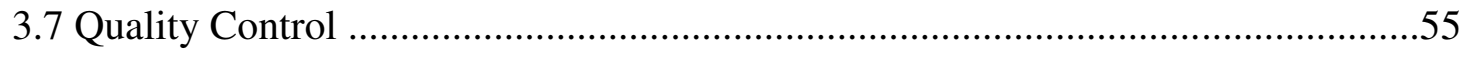

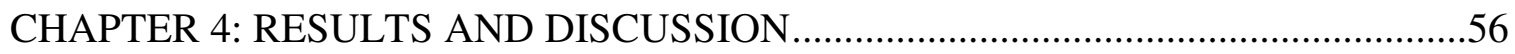

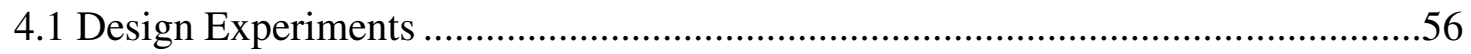

4.1.1 Configuration Experiments A-1 to A-3: Internal Filters ..............................56

4.1.2 Configuration Experiments B-1 to B-3: External Filters ………………....59

4.1.3 Configuration Experiments C-1 and C-2: Hardware..................................62

4.1.4 Configuration Experiments D-1 and D-2: Dye Studies..............................63

4.1.5 Microsphere Removal Experiments E-1 and E-2: Nominal Material

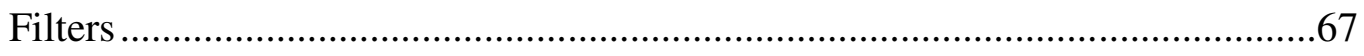

4.1.6 Microsphere Removal Experiments F-1 to F-3: Absolute Material

Filters.

4.1.7 Mixing Time Experiments G-1 to G-3: Mixing Time with 2-ply

Nominal Filters

4.2 U.S. EPA Challenge Water Experiments .........................................................

4.2.1 Experiments H-1 to H-3: Mock Challenge Water........................................74

4.2.2 Experiment I-1: Official EPA Challenge Water \#2 Attempt.......................81

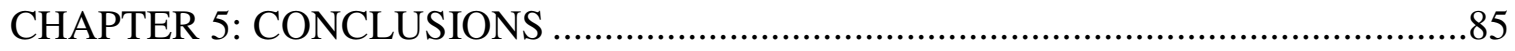

5.1 Optimization and U.S. EPA Challenge Water .........................................................

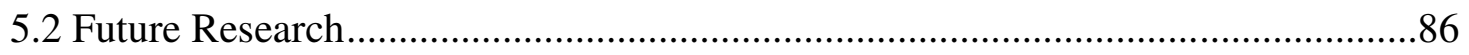

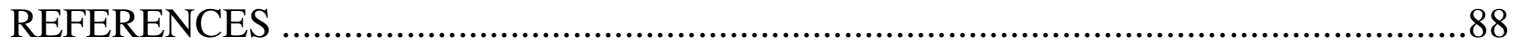

APPENDIX A: NOMINAL FILTER CLOTH PRODUCT SHEET ..................................91

APPENDIX B: ABSOLUTE FILTER CLOTH PRODUCT SHEET ……………….........97 
APPENDIX C: FLOW VS. HEAD DATA .

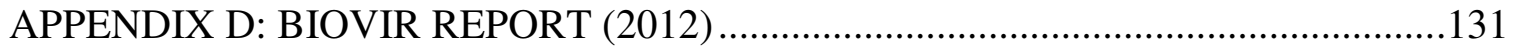




\section{LIST OF TABLES}

Table 2.1: Initial concentrations of organisms in Challenge Water \#2 and required log removals for microbiological water purifiers, as specified by U.S. EPA and NSF.

Table 2.2: U.S. EPA Challenge Water \#2 inorganic characteristics to be treated with microbiological water purifiers using halogen disinfection.

Table 3.1: Design experiment information (includes test water variables, ingredient amounts, and mixing time)

Table 3.2: Variables measured during the design experiments

Table 3.3: U.S. EPA Challenge Water experiment information including test water variables, source water types, ingredient amounts, mixing speeds, and mixing lengths.

Table 3.4: Variables measured during U.S. EPA Challenge Water experiments

Table 3.5: Characteristics of U.S. EPA Challenge Water \#2, prepared by BioVir staff (BioVir, 2012).

Table 4.1: Microsphere concentration and log removal at each step in the treatment process with 1-ply nominal filter during the Mock Challenge Water \#2 treatment attempt in experiment $\mathrm{H}-1$.

Table 4.2: Microsphere concentration and log removal at each step in the treatment process with 2-ply nominal filter during the Mock Challenge Water \#2 treatment attempt in experiment $\mathrm{H}-2$. .76

Table 4.3: Coliform and E. coli concentration and log removal at each step in the treatment process with 2-ply nominal filter during the Mock Challenge Water \#2 treatment attempt in experiment $\mathrm{H}-2$. .76

Table 4.4: Microsphere concentration and log removal at each step in the treatment process with 2-ply nominal-absolute filter during the Mock Challenge Water \#2 treatment attempt in experiment $\mathrm{H}-3$ at $50 \mathrm{~mL} / \mathrm{min}$ flowrate.

Table 4.5: Coliform and E. coli concentration and log removal at each step in the treatment process with 2-ply nominal-absolute filter during the Mock Challenge Water \#2 treatment attempt in experiment $\mathrm{H}-3$ at $50 \mathrm{~mL} / \mathrm{min}$ flowrate. 
Table 4.6: Microsphere concentration and log removal at each step in the treatment process with 2-ply nominal-absolute filter and a port screen during the Mock Challenge Water \#2 treatment attempt in experiment $\mathrm{H}-3$ at $20 \mathrm{~mL} / \mathrm{min}$ flowrate.

Table 4.7: Coliform and E. coli concentration and log removal at each step in the treatment process with 2-ply nominal-absolute filter and a port screen during the Mock Challenge Water \#2 treatment attempt in experiment $\mathrm{H}-3$ at 20 $\mathrm{mL} / \mathrm{min}$ flowrate. .80

Table 4.8: E. coli (CFU/100 mL) removal results (BioVir, 2012) ..................................82

Table 4.9: Coliphage (PFU/mL) removal results (BioVir, 2012) ..................................82

Table 4.10: Microsphere (Beads/L) removal results (BioVir, 2012) .............................82 


\section{LIST OF FIGURES}

Figure 2.1: Cryptosporidium parvum and Giardia lamblia cysts viewed with

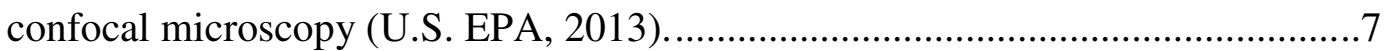

Figure 2.2: A child demonstrating how to properly use a LifeStraw ${ }^{\circledR}$.............................16

Figure 2.3: A family using the LifeStraw ${ }^{\circledR}$ Family product............................................17

Figure 3.1: Photo-micrograph of $1-\mu \mathrm{m}$ nominal filter cloth $(1000 \mathrm{X}$ total magnification)

Figure 3.2: Photo-micrograph of one layer of the absolute filter cloth (100X total magnification).

Figure 3.3: Schematic of four microfiber layers that comprise one ply of the absolute filter cloth. .20

Figure 3.4: Large diameter bulkhead fitting. ...................................................... 21

Figure 3.5: Small diameter bulkhead fittings are circled..........................................22

Figure 3.6: Filter internal spacer made of plastic mesh ...........................................23

Figure 3.7: A cross section of the 2-ply nominal-absolute filter used in experiments

$\mathrm{H}-3$ and $\mathrm{I}-1$, as constructed

Figure 3.8: Plan view of 2-ply nominal-absolute filter used in experiments $\mathrm{H}-3$ and

$\mathrm{I}-1$.

Figure 3.9: Circular internal filter made of nominal filter cloth tested in experiment

A-1

Figure 3.10: Square internal filter made of nominal filter cloth tested in experiments

A-2 and A-3.

Figure 3.11: Circular external filter made of nominal filter cloth tested in experiment B-1

Figure 3.12: Filter pouch of the square external filter made of nominal filter cloth with $500 \mu \mathrm{m}$ netting on the outside tested in experiment B-2

Figure 3.13: Filter pouch of the square external filter made of nominal filter cloth tested in experiment B-3 .28

Figure 3.14: 1-ply nominal filter tested in experiment E-1 .....................................29

Figure 3.15: 2-ply nominal filter tested in experiment E-2. .....................................29 
Figure 3.16: 1-ply Absolute filter with hot glue applied around sewn seams, tested

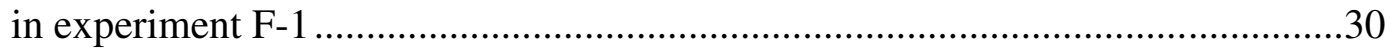

Figure 3.17: Bench-scale 2-ply nominal-absolute filter tested in experiment F-2 ..........30

Figure 3.18: 2-ply nominal-absolute filter with hot glue applied around sewn seams,

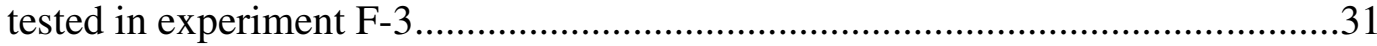

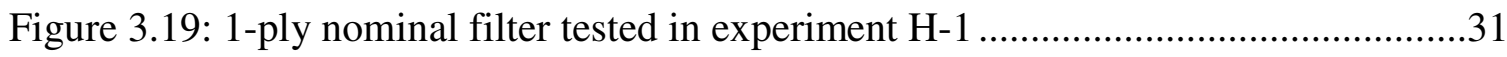

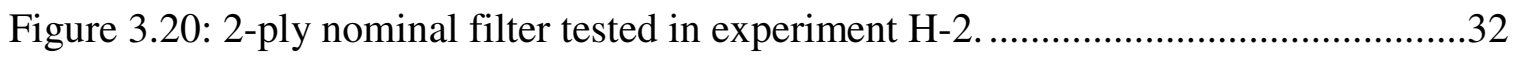

Figure 3.21: 2-ply nominal-absolute filter, sealed with Liquid Fusion, tested in experiment $\mathrm{H}-3$.

Figure 3.22: Testing in triplicate at BioVir Laboratories with composite effluent collected in cubitainers. .33

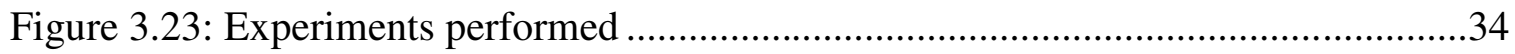

Figure 3.24: Large drum used to mix test water ..................................................... 37

Figure 3.25: Test water being mixed with a submersible sump pump. ..........................38

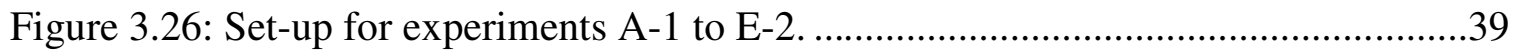

Figure 3.27: Hemacytometer used to determine the area of the FOV, observed at

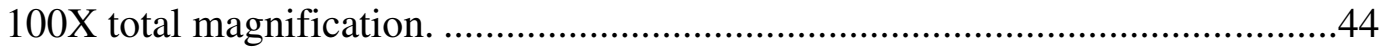

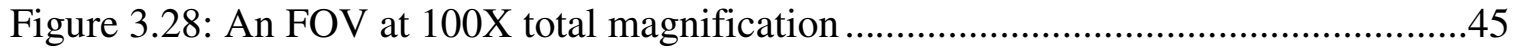

Figure 4.1: Circular filter after 12 uses, note the thick layer of floc on the filter

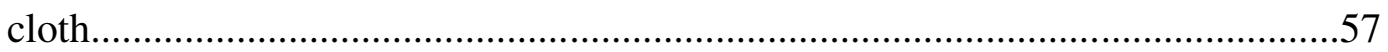

Figure 4.2: Floc caught in cone of waterbag after it had been cleaned. ..........................58

Figure 4.3: Square filter with $500-\mu \mathrm{m}$ netting after 12 uses ......................................60

Figure 4.4: Floc caught in the internal chamber of the square filter tested in

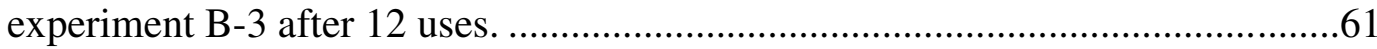

Figure 4.5: External appearance of square filter tested in experiment B-3 after 12

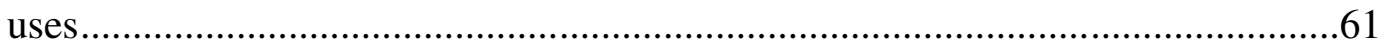

Figure 4.6: Side view of rhodamine dye and water mixture flowing through a clean, square filter in experiment D-1

Figure 4.7: Side view of rhodamine dye and water mixture flowing through a dirty, square filter in experiment D-1 
Figure 4.8: Plan view of plume of rhodamine dye and water mixture jetting out of the internal chamber of a square filter in experiment D-1

Figure 4.9: Side view of a clean, rectangular filter with a high bulkhead fitting used in experiment D-2

Figure 4.10: Side view of a dirty, rectangular filter with a middle bulkhead fitting used in experiment D-2

Figure 4.11: Side view of thin plume of rhodamine dye and water mixture observed along clean, rectangular filter tested in experiment D-2 .................................67

Figure 4.12: Experiment G-1 (5 min mix waterbag). .............................................. 70

Figure 4.13: Experiment G-1 (5 min mix waterbag) ............................................. 70

Figure 4.14: Experiment G-2 (10 min mix waterbag) .......................................... 71

Figure 4.15: Experiment G-2 (10 min mix waterbag). ........................................... 71

Figure 4.16: Experiment G-3 (15 min mix waterbag) ........................................... 72

Figure 4.17: Experiment G-3 (15 min mix waterbag) ............................................73

Figure 4.18: Turbidity of samples collected at various points from waterbags with a

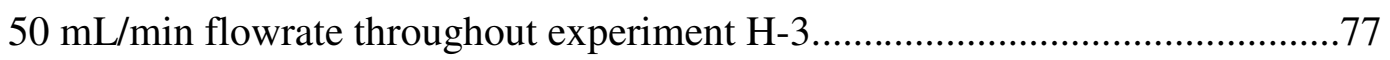

Figure 4.19: Turbidity of samples collected at various points from waterbags with a $20 \mathrm{~mL} / \mathrm{min}$ flowrate and a port screen throughout experiment $\mathrm{H}-3$. .79

Figure 4.20: Turbidity of samples collected by Cal Poly researchers during the 2012

U.S. EPA Challenge Water test from waterbags tested in triplicate. .83 


\section{CHAPTER 1: INTRODUCTION}

Globally, 783 million people, or one in nine people around the globe, lack access to clean drinking water, and 2.5 million lives could be saved each year if everyone had access to clean drinking water and adequate sanitation. For example, about 2,000 children die every day from water-related diseases (WaterAid, 2012). Beyond these chronic problems, about 255 million people are affected by natural disasters each year (DayOne Response, 2012). Survivors are susceptible to illnesses and death from diseases due to inadequate sanitation and water supplies as well as poor hygiene (The Sphere Project, 2004). Governments and relief organizations, such as the Red Cross, UNICEF, and CARE respond after natural disasters by providing basic supplies including drinking water or drinking water treatment equipment. Relief organizations typically provide clean drinking water to survivors in two ways:

1. transporting pre-treated, clean drinking water to the disaster zone, or

2. distributing point-of-use (POU) drinking water treatment devices capable of treating contaminated water in the disaster zone (DayOne Response, 2012).

Option two, mentioned above, is more ideal as POU treatment devices are more compact, and survivors can treat contaminated water on their own, with minimal additional effort by the relief organization. Also, with a POU treatment device, survivors are more likely to be able to treat water until a permanent solution is available.

Standards for humanitarian assistance have been developed by both The Sphere Project and the World Health Organization (WHO) (The Sphere Project, 2004). These standards aimed to increase the quality of assistance survivors received after a natural disaster (The 
Sphere Project, 2004). In addition to these standards, the United States Environmental Protection Agency (U.S. EPA) developed the Guide Standard and Protocol for Testing Microbiological Water Purifiers, which applies to domestic water purifiers in addition to POU purifiers. The U.S. EPA Guide Standard mandates minimum pathogen removal amounts for U.S. EPA-approved microbiological treatment devices.

Procter \& Gamble manufactures a POU drinking water treatment method: PŪR ${ }^{\circledR}$ Purifier of Water chemical sachets (PŪR ${ }^{\circledR}$ sachet). The PÛR ${ }^{\circledR}$ sachet contains various coagulants, flocculants, and disinfection chemicals, and has met the U.S. EPA Guide Standard and Protocol for Testing Microbiological Water Purifiers required pathogen removals using the procedures printed on the sachets (Procter \& Gamble, 2013). These instructions use a two-bucket treatment method. While the two-bucket method is effective for treatment, it also has some drawbacks. Namely, the method requires two 20-L buckets, a mixing tool, and a clean filter cloth. Disaster survivors or persons in the developing world may not be able to obtain these materials easily. Furthermore, the open buckets are not protected from the environment, which could allow the treated water to become re-contaminated.

Students at California Polytechnic State University, San Luis Obispo have been developing an alternative to the standard PŪR ${ }^{\circledR}$ two-bucket method since 2007 (Compas, 2009 and Herzog, 2011). This alternative uses a 10-liter plastic waterbag: the Polytech Waterbag referred to as the "waterbag" in this thesis and commercially as the DayOne Waterbag ${ }^{\mathrm{TM}}$. The waterbag system uses $\mathrm{PU}^{\circledR}{ }^{\circledR}$ for chemical treatment and also provides water collection, treatment, transport, and storage in a single unit. 
The Mark I waterbag was in development from 2007-2009. Development consisted of testing various waterbag geometries and materials as well as usability, capacity, and mixing method (Compas, 2009). The Mark I waterbag used one PŪR ${ }^{\circledR}$ sachet and met the WHO emergency drinking water guidelines, but was unable to meet the U.S. EPA pathogen removal requirements. A patent was issued for the Mark I waterbag design and features (US PTO No. 7,514,006).

The Mark II waterbag was developed and optimized during 2009-2010. Optimization methods consisted of testing various waterbag geometries, mixing durations, mixing motions, as well as baffle designs (Herzog, 2011). The Mark II waterbag was able to pass the U.S. EPA purifier standard using two PŪR ${ }^{\circledR}$ sachets. A continuation-in-part pending application was submitted to include the findings from these optimization experiments. The Mark II waterbag was used during all experiments for this research.

An important component of the waterbag system is the filter used for the final discharge, which is required to meet the standards for disaster relief water treatment. Currently, available filters are effective, but they are also expensive and bulky. The purpose of the research presented in this thesis is to develop an improved filter to be used with the waterbag and to test the efficacy of the final design. Ten filter designs were tested over the course of 22 experiments. The specific objectives of this research included:

1. Design a filter prototype to meet water quality criteria for disaster relief that is much lower cost and geometrically flatter than commercially available POU filters. Water quality criteria adopted for this work were the WHO and The 
Sphere Project emergency drinking water guidelines as well as the U.S. EPA

Guide Standard and Protocol for Testing Microbiological Water Purifiers.

2. Conduct water quality experiments at a certified commercial laboratory to determine the efficacy of the filter in meeting the WHO, Sphere Project and U.S. EPA drinking water guidelines.

The following chapter provides background on filtration, water quality criteria, and other POU water treatment technologies. 


\section{CHAPTER 2: BACKGROUND}

This chapter identifies standard drinking water contaminants, describes the U.S EPA Guide Standard and Protocol for Testing Microbiological Water Purifiers, and summarizes filtration mechanisms and technologies.

\subsection{Drinking Water Contamination during Emergencies}

Natural disasters (e.g., tsunamis, hurricanes, monsoons, mudslides, or floods) can contaminate drinking water sources and also damage drinking water treatment systems. The health of survivors is dependent in part on the supply of drinking water immediately following a natural disaster (The Sphere Project, 2004).

Drinking water contamination can be divided into two specific types: nonmicrobiological and microbiological. Non-microbiological contamination includes, among others, turbidity, $\mathrm{pH}$, natural organic matter (NOM), and dissolved solids. Nonmicrobiological contamination has been extensively reviewed in previous waterbag theses and will not be further described here (Compas, 2009 and Herzog, 2011). Microbiological contamination includes bacteria, viruses, protozoa, and helminthes (MWH, 2005). The present thesis research focused on microbiological contamination, excluding helminthes which are more easily removed or inactivated than the other pathogens. Specifically, the research focused on how to remove protozoan cysts through filtration. The following brief review will discuss the microbiological contamination of drinking water due to bacteria, viruses, and protozoan cysts only.

In order to effectively treat and remove microbiological contamination, size and reaction to disinfection must be considered. 
Bacteria-Bacteria typically range in size from $0.1 \mu \mathrm{m}$ to $10 \mu \mathrm{m}$ in diameter (MWH, 2005). As size decreases, removal efficiency by filtration decreases as well. Bacterial cells are killed when an adequate amount of disinfectant is added to the water and a proper contact time elapses (MWH, 2005).

Viruses - Viruses typically range in size from $0.02 \mu \mathrm{m}$ to $0.1 \mu \mathrm{m}$ in diameter (MWH, 2005). Due to their very small size, filtration is an ineffective removal technique. Most viruses are also killed when exposed to disinfectants, but some enteroviruses are resistant to disinfection (MWH, 2005).

Protozoa - Protozoan cysts typically range in size from $3 \mu \mathrm{m}$ to $16 \mu \mathrm{m}$ in diameter (MWH, 2005). Oocysts of Cyptosporidium, which are used as a benchmark organism in water treatment, range in size from $3 \mu \mathrm{m}$ to $5 \mu \mathrm{m}$ in diameter. Two common protozoan pathogens are Giardia lamblia and Cryptosporidium parvum (Figure 2.1). Both cause diarrhea in humans when ingested. Protozoa have a complicated lifecycle. One stage of reproduction allows the protozoa to be encased in a hard, protective shell, allowing the protozoa to survive in most environments and rendering it resistant to disinfection (MWH, 2005). Because it is resistant to disinfection, the oocyst must be physically removed from the water source via filtration. 


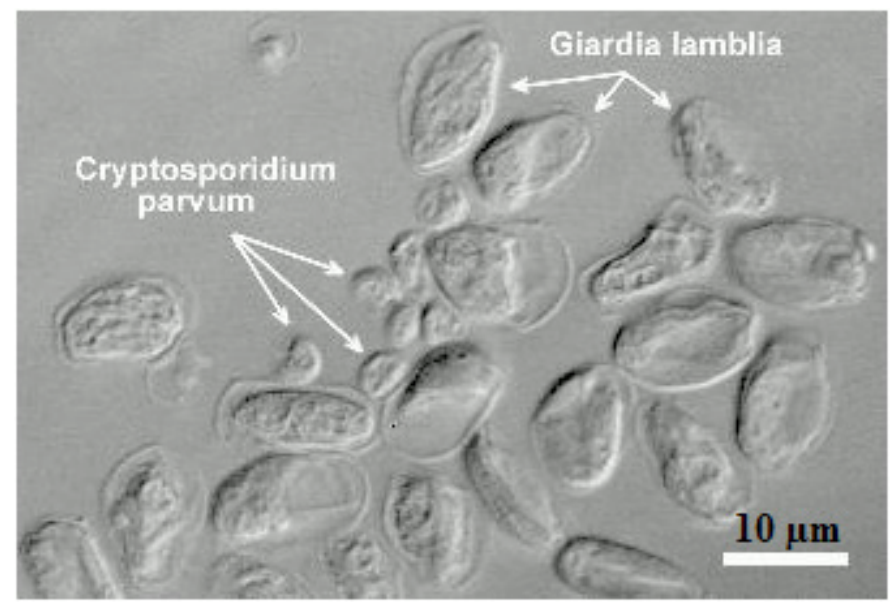

Figure 2.1: Cryptosporidium parvum and Giardia lamblia cysts viewed with confocal microscopy (U.S. EPA, 2013).

\subsection{U.S. EPA Guide Standard and Protocol for Testing Microbiological Water Purifiers}

The U.S. EPA Guide Standard and Protocol for Testing Microbiological Water Purifiers applies to microbiological water purification units that "remove, kill or inactivate all types of disease-causing microorganisms from the water, including bacteria, viruses and protozoan cysts so as to render the processed water safe for drinking” (U.S. EPA, 1987). The standard applies to three types of microbiological water purification units: ceramic filters, halogenated disinfectants, and ultraviolet disinfection (U.S. EPA, 1987). Halogenated disinfectants are disinfectants that contain an element from the halogen group on the periodic table (i.e. chlorine, iodine, or bromine) (Metcalf \& Eddy, 2003). The U.S. EPA Guide Standard describes halogenated disinfectants as a process involving both chemical disinfection and filtration.

A microbiological water purifier must meet specific removal requirements as specified in the U.S. EPA Guide Standard (Table 2.1). The U.S. EPA Guide Standard also contains requirements or "recipes" for challenge waters to be used in experiments when measuring 
performance of a microbiological water purifier. Specifically, Challenge Water \#2 was used for experiments performed during this research (Table 2.2).

Table 2.1: Initial concentrations of organisms in Challenge Water \#2 and required log removals for microbiological water purifiers, as specified by U.S. EPA and NSF.

\begin{tabular}{|c|c|c|c|}
\hline \multirow[t]{2}{*}{ Challenge Organism } & \multirow{2}{*}{$\begin{array}{c}\text { Initial } \\
\text { Challenge }^{1}\end{array}$} & \multicolumn{2}{|c|}{$\begin{array}{c}\text { Minimum Required } \\
\text { Reduction }\end{array}$} \\
\hline & & Log & $\%$ \\
\hline \multicolumn{4}{|l|}{ Bacteria: } \\
\hline \multicolumn{4}{|l|}{ Klebsiella terrigena (EPA, NSF) } \\
\hline Escherichia coli $(\mathrm{NSF})$ & $10^{7} / 100 \mathrm{~mL}$ & 6 & 99.9999 \\
\hline \multicolumn{4}{|l|}{ Bacillus atrophaeus (spore form) } \\
\hline \multicolumn{4}{|l|}{ Virus: } \\
\hline Poliovirus 1 and Rotavirus (EPA) & $10^{7} / \mathrm{L}$ & 4 & $0000^{2}$ \\
\hline MS2 and fr coliphage (NSF) & $10^{7} / \mathrm{L}$ & 4 & 99.99 \\
\hline \multicolumn{4}{|l|}{ Protozoan Cyst: } \\
\hline Giardia muris or G. lamblia (EPA) & $10^{6} / \mathrm{L}$ & 3 & 99.9 \\
\hline Particles or microspheres $4-6 \mu \mathrm{m}^{3}$ & $10^{7} / \mathrm{L}$ & 3 & 99.9 \\
\hline
\end{tabular}

1 "Influent challenges may constitute greater concentrations than would be anticipated in source waters, but these are necessary to properly test, analyze, and quantitatively determine the indicated log reductions." (U.S. EPA 1987).

${ }^{2} \mathrm{~A}$ combined 4-log reduction between both virus types listed is acceptable.

${ }^{3}$ Microspheres used in place of protozoan cysts to ensure safety of researchers. Note, microspheres simulate protozoan cysts and function similarly in test water. 
Table 2.2: U.S. EPA Challenge Water \#2 inorganic characteristics to be treated with microbiological water purifiers using halogen disinfection.

\begin{tabular}{ccc}
\hline Constituent & Challenge Value & $\begin{array}{c}\text { Recommended Materials } \\
\text { for Adjustment of Test } \\
\text { Water Characteristics }\end{array}$ \\
\hline Chlorine residual & none & deionized water \\
pH & $9.0 \pm 0.2$ & $\mathrm{HCl} \mathrm{or} \mathrm{NaOH}$ \\
TOC & $>10 \mathrm{mg} / \mathrm{L}$ & humic acids \\
Turbidity & $>30 \mathrm{NTU}$ & fine test dust ${ }^{1}$ \\
Temperature & $4^{\circ} \mathrm{C} \pm 0.1^{\circ} \mathrm{C}$ & refrigeration/ice \\
TDS & $1500 \pm 150 \mathrm{mg} / \mathrm{L}$ & sea salts \\
\hline
\end{tabular}

${ }^{1}$ Fine test dust recommended was A2 Fine Test Dust iso 12103-1.

\subsection{Filtration Mechanism and Technologies}

Filtration is defined as "a process that separates suspended particles (a dispersed solid phase) from a liquid phase by passage of the suspension through a porous medium (either membranes or granular media)" (MWH, 2005). The following characteristics should be considered when determining the correct filtration material: media type, hydraulic loading, pore-size, pore length, tortuosity, hydrophobicity, bed depth, cloth thickness, head loss, cake formation/ripening/ dirt breakthrough, flow velocity, and particle characteristics (size, surface charge, and shape). For the present thesis research, only the following characteristics were considered: hydraulic loading, cloth thickness, cake formation/ripening/dirt breakthrough, and particle characteristics (size, surface charge, and shape).

Typically, membranes are manufactured from a synthetic material and 1-mm thick or less. Granular media ranges from $0.3 \mathrm{~mm}$ to $1.2 \mathrm{~mm}$ in diameter and granular media filters range from $0.9 \mathrm{~m}$ to $1.8 \mathrm{~m}$ in depth (MWH, 2005). The goal of the present thesis 
research is to produce a compact filter to be used in conjunction with the waterbag. Therefore, the present research tested filters made of nonwoven fabric.

\subsubsection{Hydraulic Loading}

The hydraulic loading rate is defined as the liquid flow applied over the entire filter area. A 2011 study found that "hydraulic loading rates have a significant effect on the performance of porous media filters" (Wilson et al, 2011). The natural hydraulic loading rate applied to the filter cloth used for the present thesis research was too large for the filter cloth to perform effectively. Therefore, the flowrate was reduced with stopcock valves until the required microbiological removal rates were seen in treated, filtered effluent.

\subsubsection{Cloth Thickness}

Cloth thickness directly affects the head loss across the filter material. Head loss and filter material thickness are proportional to each other in that the thinner the filter material is, the lower the head loss (MWH, 2005).

\subsubsection{Cake Formation/Ripening/Dirt Breakthrough}

In membrane filtration, the dominant removal mechanism is straining and the other two removal mechanisms are cake filtration (i.e., schmutzdecke) and adsorption. As solids build-up against the filter cloth, a filter cake forms. The filter cake acts as a filtration material and provides another method of particle rejection. Cake formation increases the filter's resistance to flow and leads to an increase in transmembrane pressure. Due to the build-up of solids, membrane filters are typically backwashed in order for the filter to continue functioning properly (MWH, 2005). 
After a filter is backwashed, there is a period of time that passes while the filter is maturing. This is referred to as the ripening period. Typically, the water collected during the ripening period does not meet drinking water standards and should be discarded. A filter has completed the ripening period when effluent turbidity has returned to typical values (Suthaker, Smith, and Stanley, 1998). In the ripening period, particles are being caught by the clean filter particles; as more particles accumulate, the filter becomes more efficient at collecting additional particles (MWH, 2005).

Breakthrough occurs when the filter can no longer contain any more particles. At this point, particles can pass through the filter, causing an increase in effluent turbidity. Once breakthrough occurs, the filter must be backwashed before it can be used again (MWH, 2005).

\subsubsection{Particle Characteristics}

Particle characteristics include size, surface charge, and shape. Particles typically range in size from 0.001 to $100 \mu \mathrm{m}$; colloidal particles range from 0.001 to $1 \mu \mathrm{m}$ and suspended particles are $>1 \mu \mathrm{m}$ in diameter. Size is important as this dictates the pore size required in the chosen filter material. Natural waters typically are heterodispersed, or contain particles of a range of sizes (MWH, 2005).

Particle surface charge contributes to the stability of particles in a solution, which leads to particles staying in suspension in a solution. When particles stay in solution, this increases turbidity of the water sample. Surface charge can be caused by four different happenings: crystal imperfections, structural imperfections, preferential adsorption of specific ions, and ionization of inorganic groups on particulate surfaces. Crystal 
imperfections arise when a metal in a metal oxide is replaced by a metal atom with a lower valence, resulting in a negative surface charge on the particle. Structural imperfections occur during the formation of the crystal. Broken bonds along the crystal edge can lead to surface charges. Preferential adsorption of specific ions occurs when a particle adsorbs natural organic matter (NOM, i.e. fulvic acid). NOM is a large macromolecule that contains carboxylic acid groups, which has a negative charge. Ionization of inorganic groups on particulate surfaces occurs when the solution the particles are in is either above or below the particle's zero point of charge $\mathrm{pH}$. When the $\mathrm{pH}$ of the solution is above the zero point of charge, the surface charge will be negative (anionic). When the $\mathrm{pH}$ of the solution is below the zero point of charge, the surface charge will be positive (cationic) (MWH, 2005).

Particles in water are a variety of shapes: spheres, semi-spheres, ellipses, rods, disks, strings, and coils. Particle shape varies depending of source water characteristics and affects the electrical properties of the particle, the particle-particle interactions, and particle-solvent interactions (MWH, 2005).

\subsubsection{Nonwoven Filter Material}

Nonwoven filter material is defined as a "porous fabric composed of a random array of fibers or filaments and whose specific function is to filter and/or separate phases and components of a fluid being transported through the medium or to support the medium that does the separation" (Hutten, 2007).

The cloth used for filter construction in the present thesis research was manufactured from polypropylene bag filters. Polypropylene is the most hydrophobic of all industrial- 
grade membrane materials. Polypropylene is also durable, chemically and biologically resistant, tolerant of high temperatures, and tolerant of a wide $\mathrm{pH}$ range (1 to 13). However, polypropylene is not tolerant of chlorine (MWH, 2005).

\subsubsection{Point-of-Use Filtration Technologies}

The following section provides a synopsis of current filtration technologies for POU microbiological treatment devices. The technologies to be discussed are cotton filters (i.e. sari cloth or t-shirt), ceramic filters, LifeStraw ${ }^{\circledR}$, LifeStraw ${ }^{\circledR}$ Family, hallow-fiber microfilters, sheet microfilters, and bag filters.

Cotton Filters: A filter made from cotton is quite simple but not entirely effective. Compas (2009) found that when turbidity of tap water was increased to at least 350 NTU with the addition of kaolin acid-washed powder, at least three layers of $100 \%$ cotton t-shirt material were required before filtered effluent turbidity decreased below $10 \mathrm{NTU}$ and five layers were needed to decrease filtered effluent turbidity to $<5$ NTU. Another cotton material commonly used is sari cloth, but this material exhibits the same non-effective microbiological removal that t-shirts do. It was found that folding a sari cloth four times only removed 99\% (2-log removal) of Vibro cholera (Colwell, 2003).

Ceramic Filters: Filters made of ceramic are produced from a mixture of combustible material and clay (Jellison et al, 2009). Ceramic filters do not have a specified pore size as pores are formed in the firing process (Jellison et al, 2009). Filters are sometimes coated with colloidal silver, which kills pathogens. Specifically, "silver disables the enzyme that pathogenic bacteria and fungi use 
for oxygen metabolism, thus suffocating them; destroys pathogens with an electric charge; renders pathogens unable to reproduce; and, kills parasites while in their egg stage" (CAWST, 2006). Ceramic filters have been shown to reduce total coliform levels to non-detectable limits $93 \%$ of the time in field studies (Clasen, 2007). The drawbacks of ceramic filters are that education is required for correct use (Clasen \& Smith, 2005) and that no chlorine residual is present in stored water (Woodrow Wilson International Center for Scholars, 2006).

Bag Filters: Bag filters are available in both felt, nominally-rated cloth and highefficiency microfiber cloth (Rosedale, 2011 and Rosedale, 2012). All bags are available in either polyester or polypropylene and are available in $1-\mu \mathrm{m}$ pore-size (Rosedale, 2011 and Rosedale, 2012). The high-efficiency microfiber material bag has a $4.4 \mathrm{ft}^{2}$ area and the capacity to hold $79 \mathrm{~g}$ of dirt (Rosedale, 2012).

Flat Sheet Microfilters: Flat sheet microfilters are produced as one solid sheet. Only a single layer is used and it must be placed in a special filtration cell. Flat sheet microfilters are most commonly used in laboratory separations and are challenging to implement on an industrial scale (MWH, 2005).

Spiral Wound Microfilters: Spiral-wound microfilters are produced from stacked layers of flat sheet membranes (described above) with permeate and retentate spacers inserted in-between the layers. The layers and spacers are then rolled/wrapped around a tube. The tube allows the permeate to travel into the central collection tube. 
Hollow Fiber Microfilters: Hollow fiber microfilters are produced as individual hollow tubes, the outside diameter ranges from $0.5 \mathrm{~mm}$ to $2 \mathrm{~mm}$, and the wall thickness ranges from $0.07 \mathrm{~mm}$ to $0.6 \mathrm{~mm}(\mathrm{MWH}, 2005)$. Transmembrane pressures typically range from 0.2 to 1 bar. Hollow fiber microfilters are the most common membrane filtration system currently used in water treatment (MWH, 2005).

LifeStraw $w^{\circledR}$ : LifeStraw ${ }^{\circledR}$ has been proven to meet the U.S. EPA Guide Standard and Protocol for Testing Microbiological Purifiers with no chemical treatment (Vestergard-Frandsen, 2011). Water travels through a 1-mm pore-size pre-filter (removes large particles and debris), and finally through a $0.2-\mu \mathrm{m}$ hollow-fiber microfiltration membrane (Vestergard-Frandsen, 2011). Figure 2.2 shows a child properly using a LifeStraw ${ }^{\circledR}$. A LifeStraw ${ }^{\circledR}$ has a usable life of roughly $1,500 \mathrm{~L}$ and an average flowrate over filtration lifetime of $200 \mathrm{~mL} / \mathrm{min}$ (VestergardFrandsen, 2011). Frequent backwashing is suggested (at maximum, after every 5 L is drank) in order to improve the usable life of the LifeStraw ${ }^{\circledR}$ (VestergardFrandsen, 2011). 


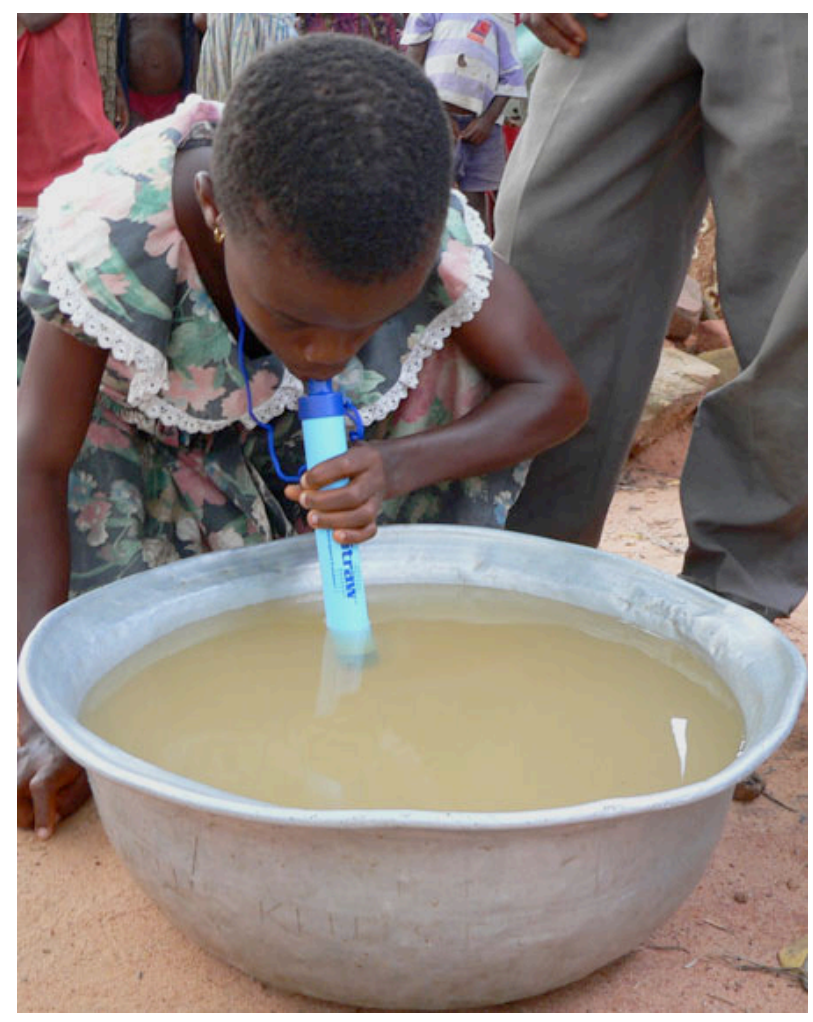

Figure 2.2: A child demonstrating how to properly use a LifeStraw ${ }^{\circledR}$ (VestergardFrandsen, 2011).

LifeStraw ${ }^{\circledR}$ Family: LifeStraw ${ }^{\circledR}$ Family has also been proven to meet the U.S. EPA Guide Standard and Protocol for Testing Microbiological (VestergardFrandsen, 2011). However, LifeStraw ${ }^{\circledR}$ Family contains a halogen chamber that releases chlorine into the water to reduce membrane fouling (VestergardFrandsen, 2011). In the LifeStraw ${ }^{\circledR}$ Family device, water first passes through an $80-\mu \mathrm{m}$ pre-filter, then a halogen chamber, then a 20 -nm hollow-fiber ultrafiltration membrane (Vestergard-Frandsen, 2011). The small pore-size of the ultrafiltration membrane requires a large amount of head (Figure 2.3). The LifeStraw ${ }^{\circledR}$ Family device has a usable life of up to 18,000 L of water (enough water for family of five for three years) at a flowrate of approximately $12-15 \mathrm{~L} / \mathrm{hr}$ (Vestergard-Frandsen, 2011). Frequent backwashing is suggested in order to 
increase the usable life of the LifeStraw ${ }^{\circledR}$ Family device (Vestergard-Frandsen, 2011).

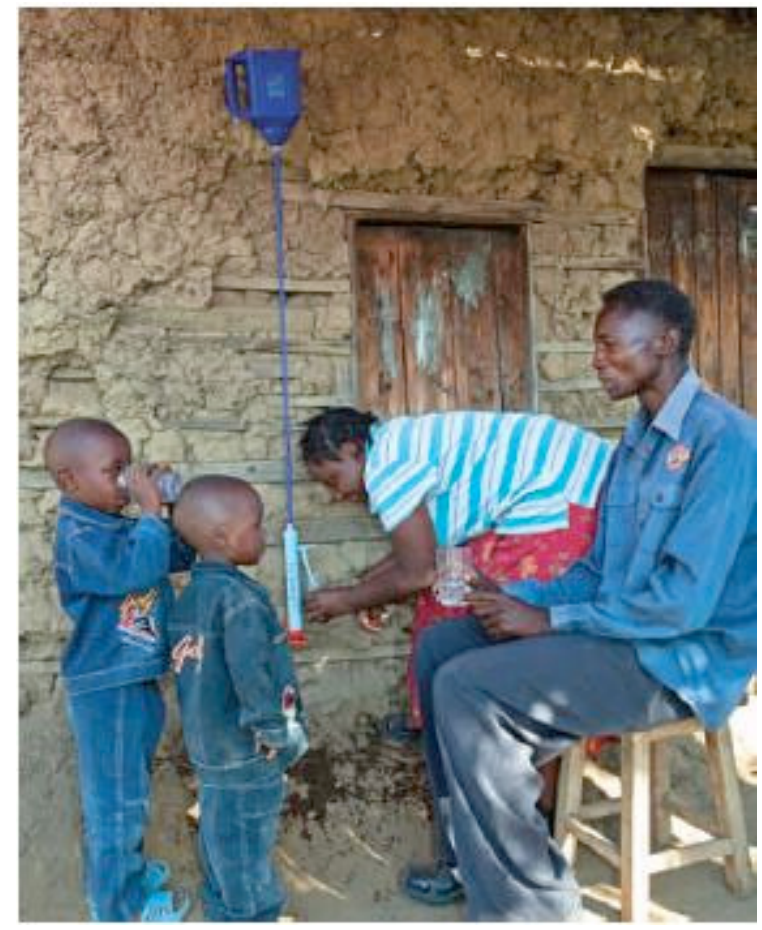

Figure 2.3: A family using the LifeStraw ${ }^{\circledR}$ Family product. Note the height the reservoir must be hung at in order for the unit to perform effectively (VestergardFrandsten, 2011).

Cotton filters and ceramic filters were not pursued for the present thesis research as the filter material is not able to meet U.S. EPA removal requirements. Due to the high cost and fragile nature of flat sheet, spiral wound, and hollow fiber microfilters, none were pursued in the present thesis research. Bag filters were chosen for the present research because of the low cost and ability to meet U.S. EPA removal requirements. The materials and methods used are described in the following chapter. 


\section{CHAPTER 3: MATERIALS AND METHODS}

This chapter describes the filter design iterations, the waterbag systems operation procedures, the experimental designs for testing the filters, and the testing at Cal Poly. The culminating U.S. EPA Challenge Water testing at BioVir Laboratories is also described.

\subsection{Filter Construction}

Numerous filters were constructed for the present thesis research. Initially, 1-ply filters were constructed of the nominal filter cloth (further described in Section 3.1.1) in circular, square, and rectangular shapes. Both internal and external filters of the above mentioned shapes were constructed. Next, 2-ply filters were constructed of the nominal filter cloth in rectangular shapes. Then, 1-ply filters were constructed of the absolute filter cloth (further described in Section 3.1.1) in rectangular shapes. The final filter type constructed was the 2-ply nominal-absolute filter (further described in Section 3.1.2). The construction of this filter is described in detail in Section 3.1.2.

\subsubsection{Materials Used for Filter Construction}

All various materials used to construct filters are described herein. These materials include filter cloth, nylon netting, bulkhead fittings, and washers.

The 1-ply and 2-ply nominal filter prototypes were constructed of $1-\mu \mathrm{m}$, nominal-50\% polypropylene felt filter cloth (hereinafter referred to as nominal filter cloth), with standard finish (Rosedale, 2011) (Figure 3.1). Nominal-50\% means that the filter cloth will remove $50 \%$ of all particles $1 \mu \mathrm{m}$ in diameter and allow the remaining $50 \%$ of particles $1 \mu \mathrm{m}$ in diameter to pass through the filter cloth. Standard finish means that the 
nominal filter cloth had not been coated in a glaze, as glazed finish filter cloth is also available for purchase. The nominal filter cloth was made of polypropylene fibers of various weight, diameter, and thickness that functions as a depth-type filter media (Rosedale, 2011). The product sheet for the nominal material can be found in Appendix A.

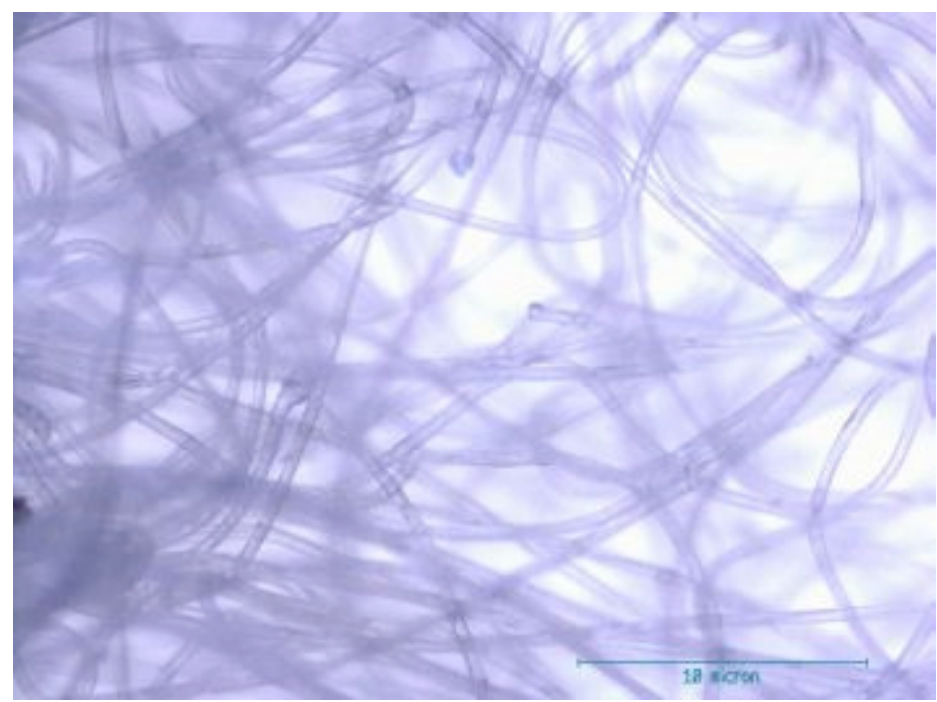

\section{Figure 3.1: Photo-micrograph of 1- $\mu \mathrm{m}$ nominal filter cloth (1000X total magnification) (Compas, 2009).}

The 1-ply absolute filter prototypes were constructed of 1- $\mu \mathrm{m}$ high efficiency-95\% polypropylene microfiber filter cloth (hereinafter referred to as absolute filter cloth) (Rosedale, 2012) (Figure 3.2). The absolute filter cloth was comprised of four separate material layers (Figure 3.3). High-efficiency-95\% means that 95\% of particles $1 \mu \mathrm{m}$ in diameter will be removed and only $5 \%$ of particles $1 \mu \mathrm{m}$ in diameter will pass through the filter cloth. The product sheet for the absolute material can be found in Appendix B. 


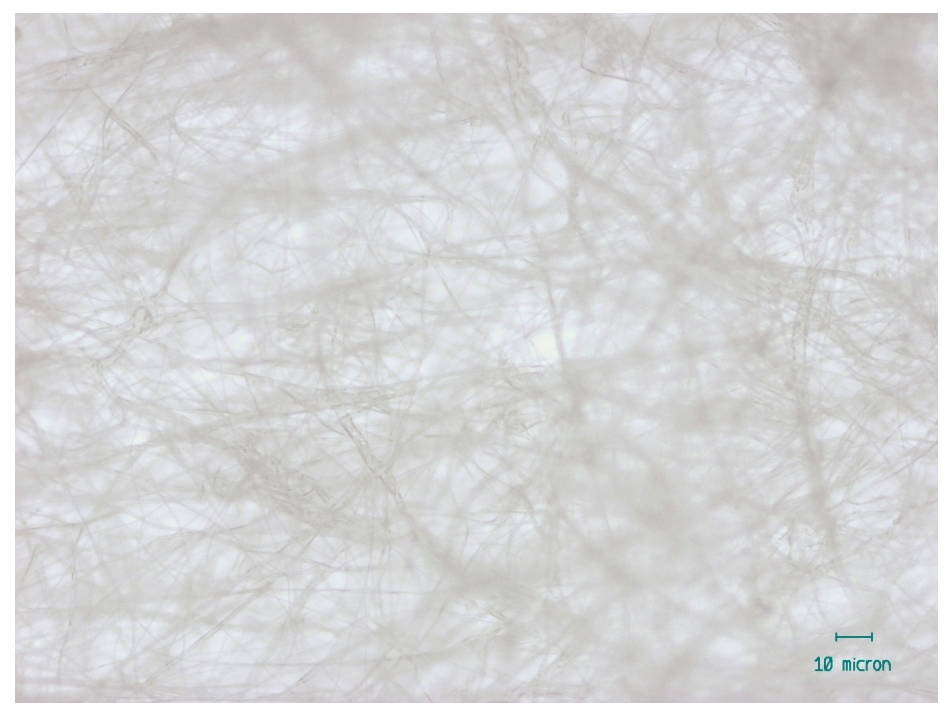

Figure 3.2: Photo-micrograph of one layer of the absolute filter cloth (100X total magnification). This picture only represents one plane of focus of this material; there are multiple planes. A large gap in this plane of focus would likely be covered by fibers in the next plane of focus.

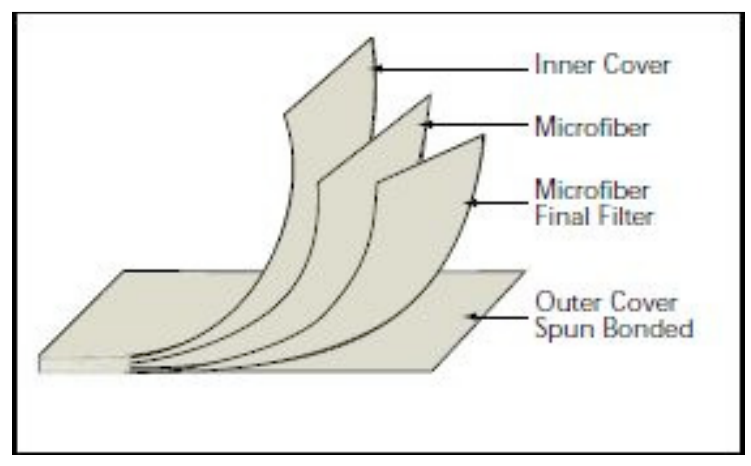

Figure 3.3: Schematic of four microfiber layers that comprise one ply of the absolute filter cloth (Rosedale, 2011). Water flows through the inner cover through the filter layers and then through the outer cover.

The 2-ply nominal-absolute filter prototypes were constructed of an inner layer of nominal filter cloth which was then encased in an outer layer of absolute filter cloth.

Figure 3.7 shows a cross-section of this filter as constructed.

The nylon, 500-micron netting that was used on the exterior of filters in experiments A-3 and B-2was purchased from Aquatic Eco-Systems (Part \#M500). The 500-micron 
netting was attached to the exterior of filters to prevent flocs from being embedded in the filter cloth. This netting was resistant to bacteria, cleaners, as well as acids and had $49 \%$ open space.

Miniature PVC tank adapters (hereinafter referred to as large diameter bulkhead fittings) were purchased from Ryan Herco Flow Solutions (Catalog \# 7000.002) (Figure 3.4) (Ryan Herco, 2012). The large diameter bulkhead fittings were used in all experiments except C-2.

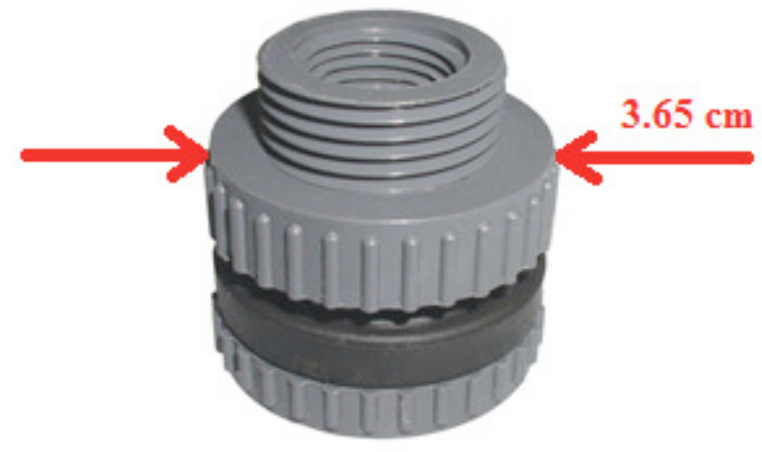

Figure 3.4: Large diameter bulkhead fitting (Ryan Herco, 2012).

Nylon miniature though-wall fittings (hereinafter referred to as small diameter bulkhead fittings) were purchased from McMaster-Carr (Catalog \# 8671T23) (McMaster-Carr, 2011) (Figure 3.5). Nylon flat washers (hereinafter referred to as flat washers) were purchased from Grainger (Item \# 5XU62) (Grainger, 2011). The small diameter bulkhead fittings and flat washers were used for experiments C-2 and D-2. The inner diameter of the flat washers was not large enough to fit over the small diameter bulkheads, so the washers were bored-out with a drill press in Cal Poly's machine shop. 


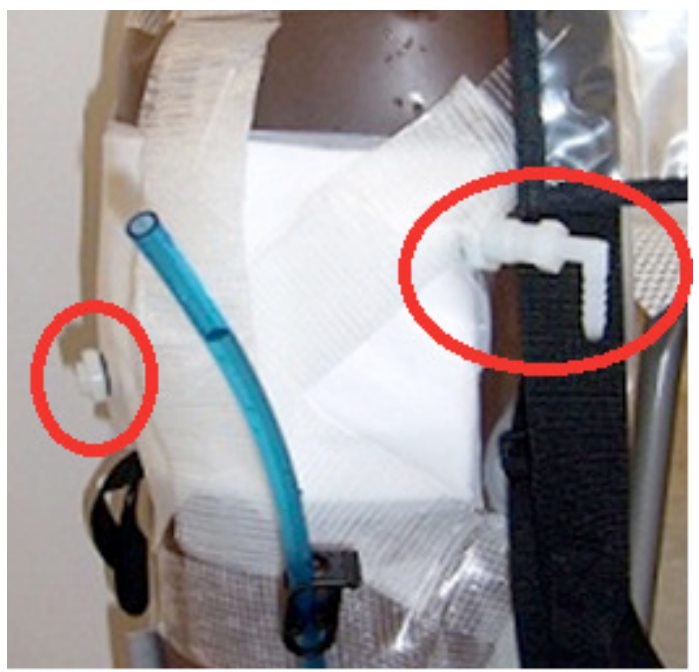

Figure 3.5: Small diameter bulkhead fittings are circled.

\subsubsection{Construction of 2-ply Nominal-Absolute Filter (tested at BioVir Laboratories)}

An element used consistently in all filters was an internal spacer made of 7 count plastic canvas (Darice, Manufacturer \#33900-1) to provide an open path for the water to contact the cloth (Figure 3.6). To make a spacer, a $6-\mathrm{cm}$ by $12-\mathrm{cm}$ rectangular piece of the canvas was folded over five 5-cm square pieces of the mesh to increase the size of the water path. Three edges of the spacers were whip-stitched with white, $100 \%$ polyester thread. 


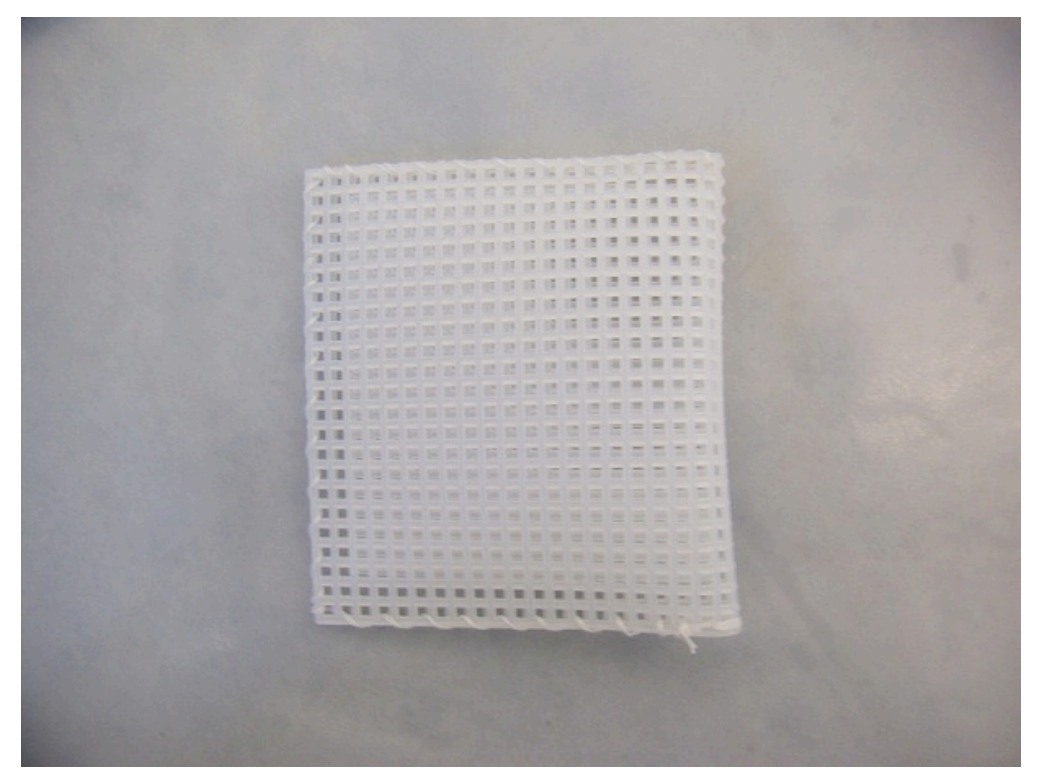

Figure 3.6: Filter internal spacer made of plastic mesh. As constructed, the final dimensions were $6 \mathrm{~cm}$ square by a maximum of $1 \mathrm{~cm}$ thick. Three edges are stitched close with white thread.

Once the internal spacer was finished, the filter cloth was cut out to fit around the spacer. A 1-cm diameter hole was then punched through the filter cloth and a large diameter bulkhead fitting was installed through the hole. The filter cloth was then sealed on the three loose sides using heat-activated Super Weight Stitch-Witchery Fusible Bonding (Drtiz, Manufacturer \#D223). The Stitch Witchery was placed in-between two layers of filter cloth, the filter cloth was covered with a damp cloth, a steam iron, set to "wool," was pressed on each side of the filter for $10 \mathrm{sec}$. Figure 3.7 shows a cross section of the filter as constructed.

Next, a layer of absolute filter cloth was prepared the same way and added over the nominal filter cloth. The bulkhead fitting (secured inside the nominal filter cloth) was fit through the hole in the external layer of absolute filter cloth. The external layer of absolute filter cloth was then also sewn on three sides using a sewing machine. Liquid Fusion clear urethane glue (Duncan Enterprises, 2012), was placed over all sewn seams 
and in-between filter cloth plies around the edge of the filter. Liquid Fusion was chosen as it is non-toxic, odorless, and waterproof. Originally, hot glue was placed on all sewn seams and in-between filter cloth plies around the edge of the filter, but it was determined that hot glue was not water proof and therefore not effective.

All constructed filters were encased in a pouch constructed of one sheet of 6-mil low density polyethylene (LDPE) plastic. The 6-mil LDPE plastic sheeting was purchased from Plastic Sheeting Supply (IPS Packaging) in $1.83 \mathrm{~m}$ by $30.48 \mathrm{~m}$ rolls (Compas, 2009). A hole was punched through the plastic and stretched over the bulkhead fitting protruding from the filter. An additional hole was punched through the plastic outside the edge of the filter to allow for another bulkhead fitting. The additional hole was placed outside the edge of the filter to prevent flow-focusing of effluent. As can be seen in Figure 3.15, when the bulkhead fitting was not placed outside the edge of the filter, the flow is focused in that area and floc can be drawn through the filter material. The 6 mil LDPE pouch was sealed on the two loose sides with a Tabletop Poly Bag Sealer (Impulse, Model H-1029, ULINE ${ }^{\circledR}$ Shipping Supply Specialists). Once partially sealed, a bulkhead fitting was fit through the second hole in the filter pouch, and the last seal was then sealed. Plastic stopcock valves were threaded into both the pouch inlet and outlet bulkhead fittings to allow for flow control. A diagram of the cross-section of the filter is in Figure 3.7. A side view of the filter is in Figure 3.8. 


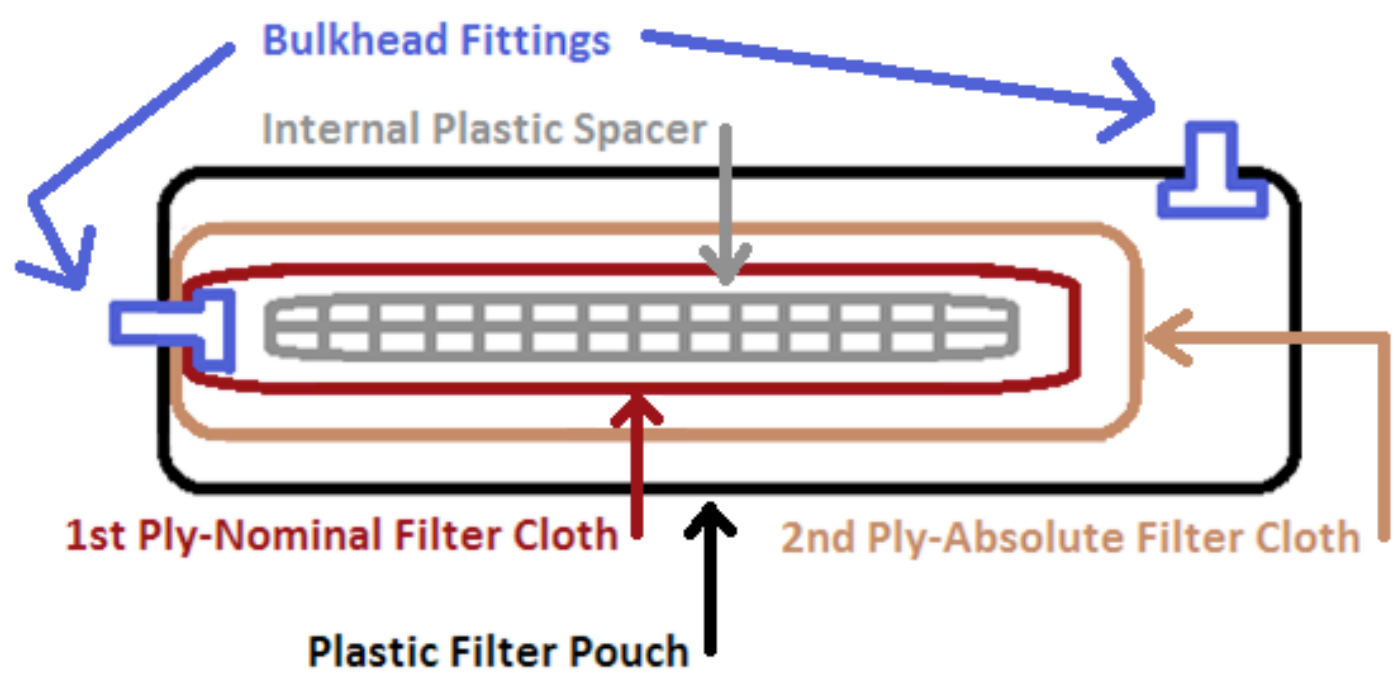

Figure 3.7: A cross section of the 2-ply nominal-absolute filter used in experiments $\mathrm{H}-3$ and I-1, as constructed. Water flows in the bulkhead fitting on the left, through the filter cloth layers, and out the bulkhead fitting on the right. Note, the base of the bulkhead fitting on the left is inside of the nominal filter cloth. Also note, in order to make the tightest seal possible, the rubber gasket for the bulkhead fitting was placed between the absolute filter cloth and the plastic filter pouch, and the nut for the bulkhead fitting was screwed onto the bulkhead fitting outside the plastic filter pouch.

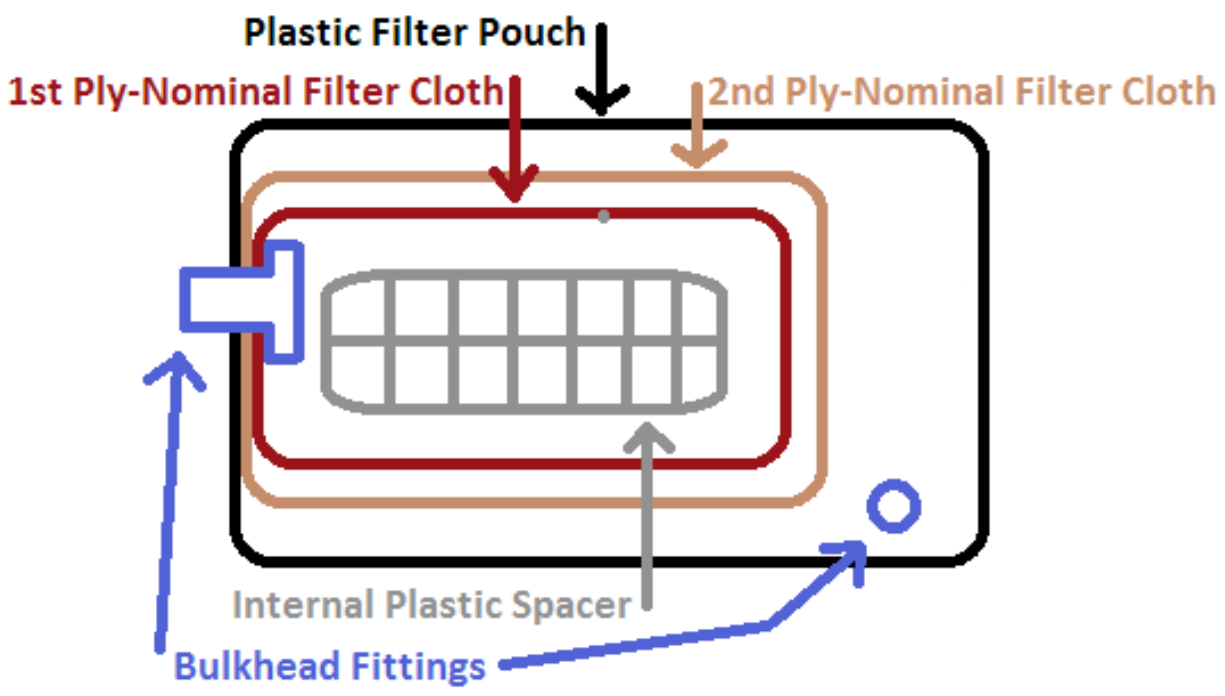

Figure 3.8: Plan view of 2-ply nominal-absolute filter used in experiments $\mathrm{H}-3$ and I1. Water flowed in the bulkhead fitting on the left, through the filter cloth layers, and out the bulkhead fitting on the right. 


\subsection{Filter Designs}

All experiments conducted for this research were performed using Mark II waterbags (Herzog 2011). Various filters were attached to the waterbag as denoted in the experiment name (described in Section 3.3). The rationale followed when developing filters is further described in Chapter 4. All filters were designed without backwashing. Initially 1-ply nominal internal filters of various shapes were tested (Figure 3.9 and Figure 3.10). Then 1-ply nominal external filters of various shapes were tested (Figure

\subsection{1, Figure 3.12, and Figure 3.13).}

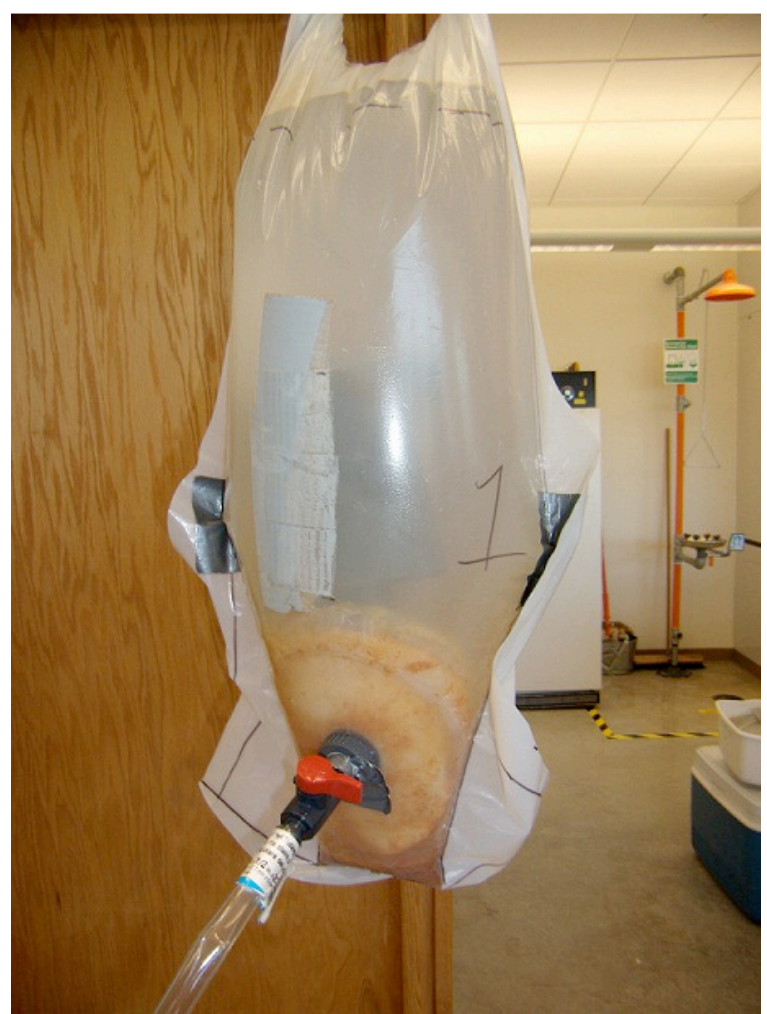

Figure 3.9: Circular internal filter made of nominal filter cloth tested in experiment A-1. Scale: the large diameter bulkhead fitting measures $3.65 \mathrm{~cm}$ in diameter. 


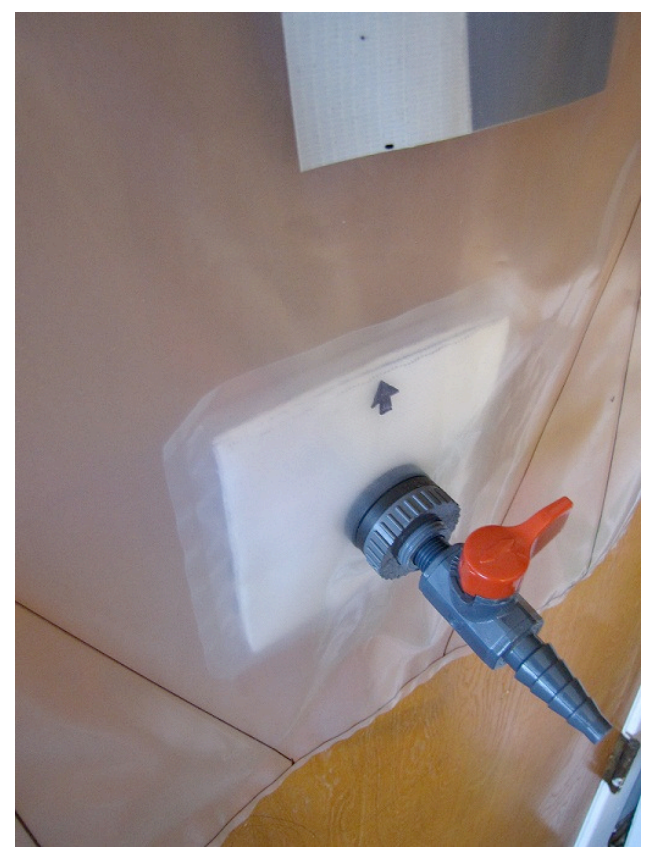

Figure 3.10: Square internal filter made of nominal filter cloth tested in experiments A-2 and A-3. The filter tested in A-2 was made of nominal material and the filter tested in A-3 was made of nominal material with $500 \mu \mathrm{m}$ netting on the outside of the filter to prevent flocs from clogging the pores of the nominal filter cloth. Scale: the large diameter bulkhead fitting measures $3.65 \mathrm{~cm}$ in diameter.

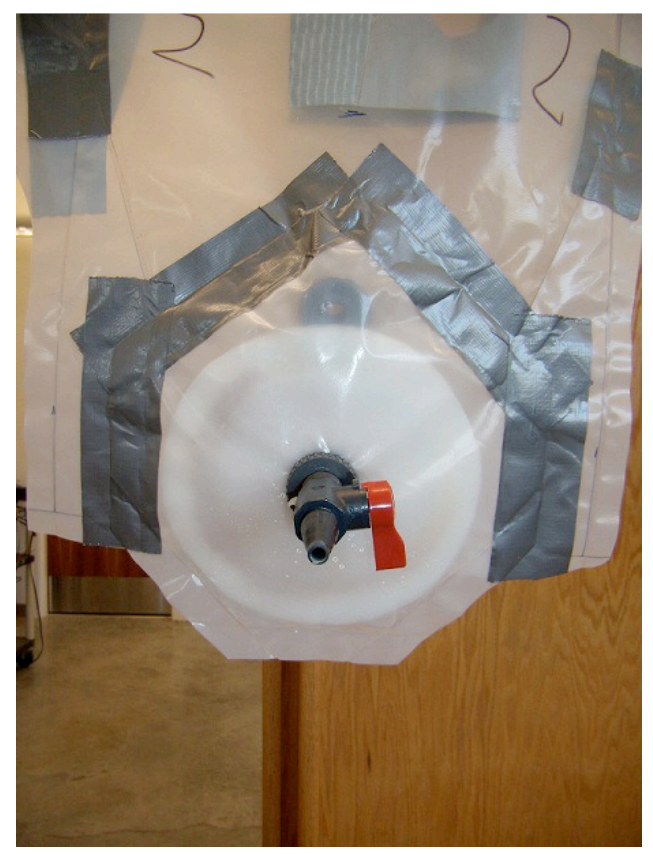

Figure 3.11: Circular external filter made of nominal filter cloth tested in experiment B-1. Scale: the large diameter bulkhead fitting measures $3.65 \mathrm{~cm}$ in diameter. 


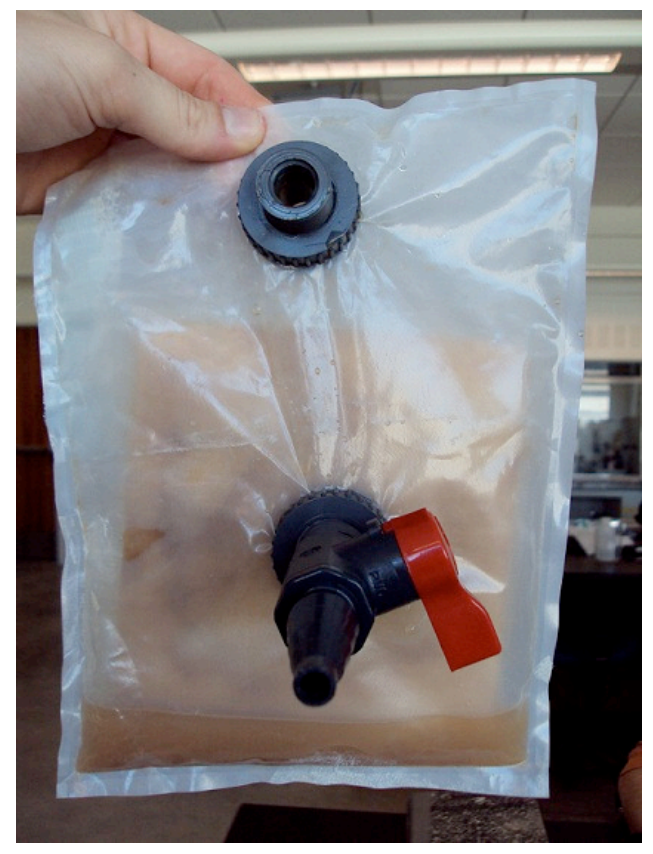

Figure 3.12: Filter pouch of the square external filter made of nominal filter cloth with $500 \mu \mathrm{m}$ netting on the outside tested in experiment B-2. Water flowed from the waterbag, into the filter pouch (outside the filter), through the filter, and into the internal chamber of the filter before flowing out as filtered effluent. Scale: the large diameter bulkhead fitting measures $3.65 \mathrm{~cm}$ in diameter.

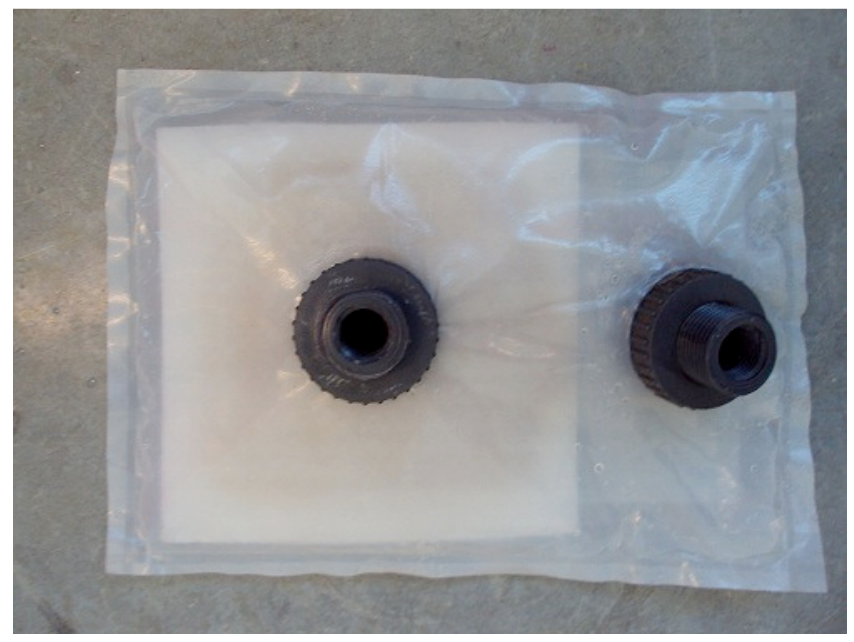

Figure 3.13: Filter pouch of the square external filter made of nominal filter cloth tested in experiment B-3. Water flowed from the waterbag, into the internal chamber of the filter, through the filter, and was collected in the filter pouch (outside the filter) before flowing out as filtered effluent. Scale: the large diameter bulkhead fitting measures $3.65 \mathrm{~cm}$ in diameter. 
Both 1-ply and 2-ply nominal filters were tested for microsphere removal capabilities

(Figure 3.14 and Figure 3.15).

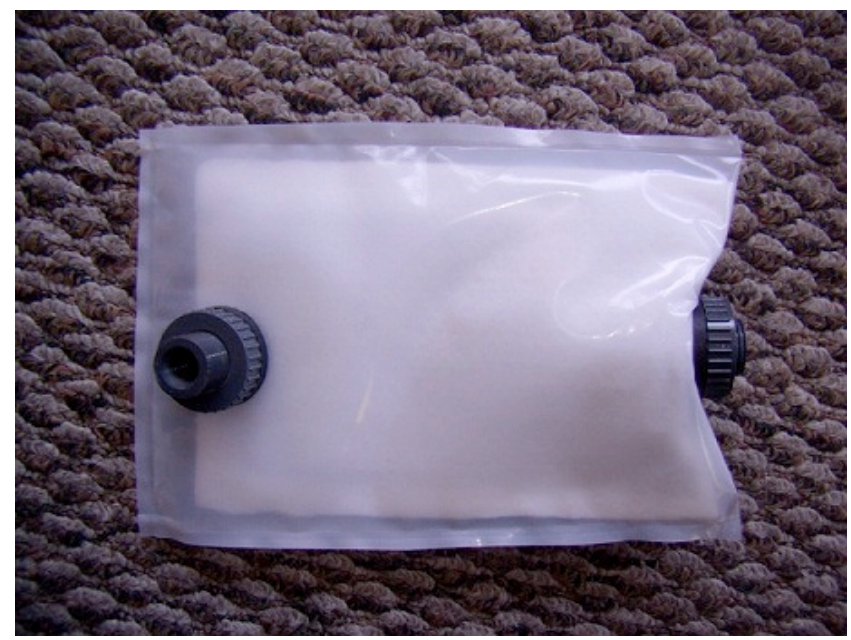

Figure 3.14: 1-ply nominal filter tested in experiment E-1. Scale: the large diameter bulkhead fitting measures $3.65 \mathrm{~cm}$ in diameter.

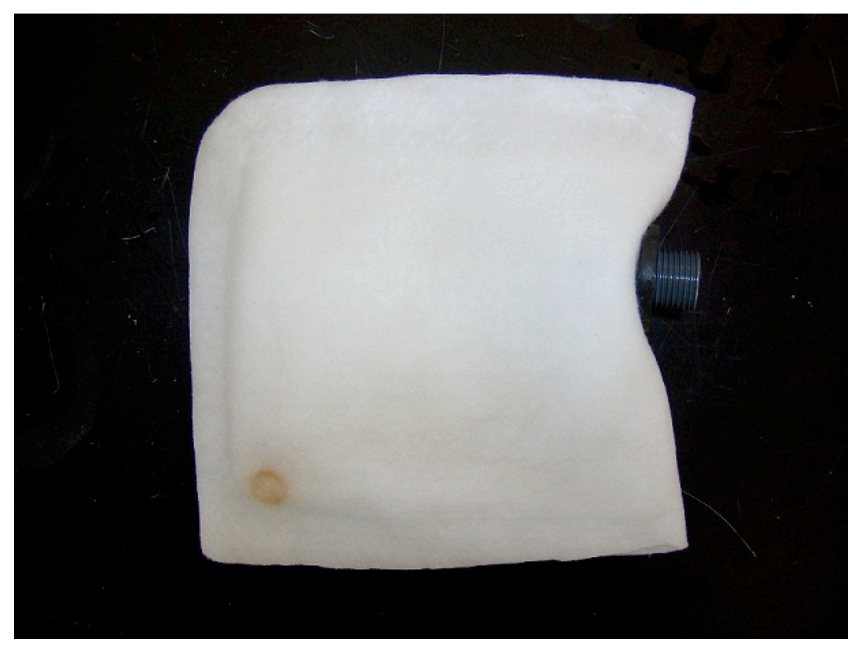

Figure 3.15: 2-ply nominal filter tested in experiment E-2. The plastic pouch was removed before this picture was taken. Scale: this filter measures $11.4 \mathrm{~cm}$ by 11.4 cm. This photo was taken after use. Note the brown circle in the bottom, left hand corner of the filter. The brown circle is a stain caused by flocs and illustrates apparent focusing of flow in that area due to improper placement of the bulkhead fitting over the filter. Flow focusing is presumed to be detrimental to cyst removal.

Then, the 1-ply absolute filter, a bench-scale model of the 2-ply nominal-absolute filter and the 2-ply nominal-absolute (sealed with hot glue) filter were tested for microsphere 
removal capabilities, as described in Section 3.4 (Figure 3.16, Figure 3.17, and Figure 3.18).

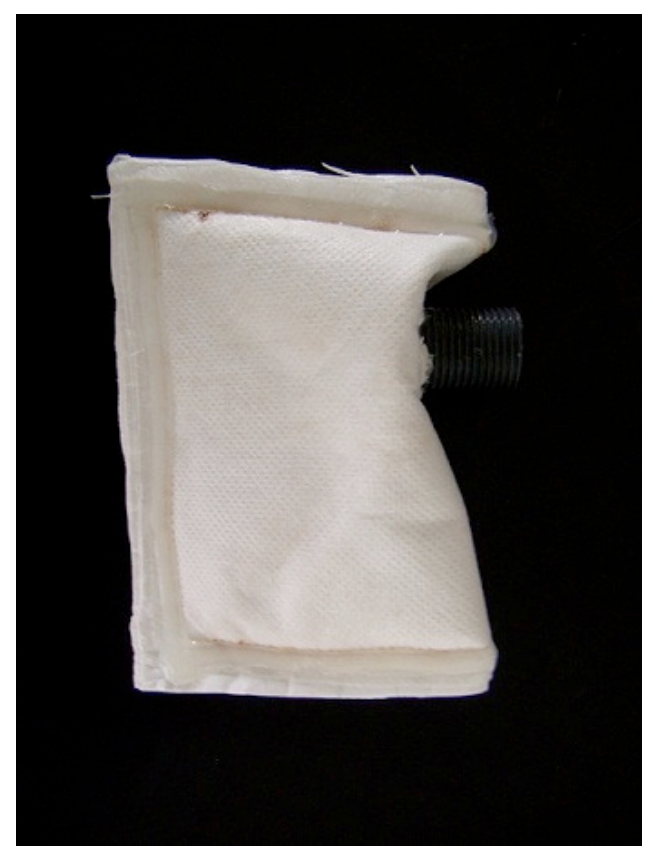

Figure 3.16: 1-ply Absolute filter with hot glue applied around sewn seams, tested in experiment F-1. The plastic pouch was removed before this picture was taken. Scale: this filter measures $10.2 \mathrm{~cm}$ by $6.4 \mathrm{~cm}$.
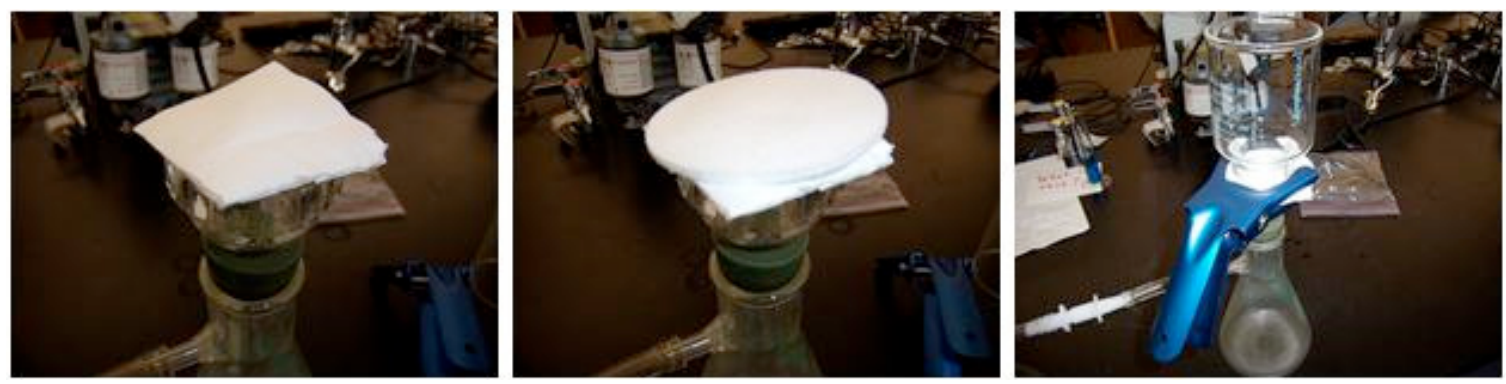

Figure 3.17: Bench-scale 2-ply nominal-absolute filter tested in experiment F-2. A $7.6 \mathrm{~cm}$ square of the absolute material was placed on the bottom of the vacuum filter housing (left picture), a laser-cut circle of the nominal material was placed on top of that (middle picture), and the top of the vacuum funnel housing was clamped in place over the two filter cloths (right picture). 


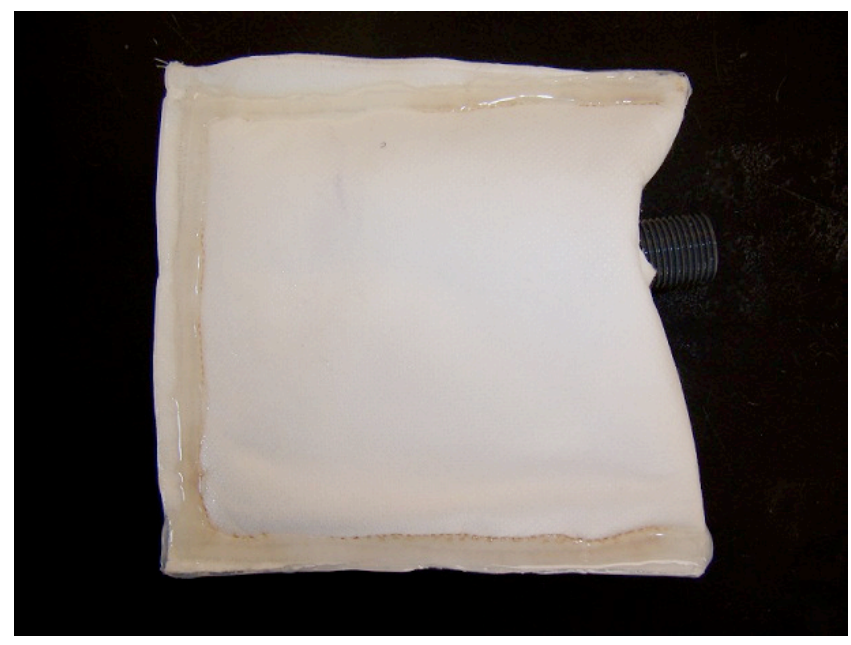

Figure 3.18: 2-ply nominal-absolute filter with hot glue applied around sewn seams, tested in experiment F-3. The plastic pouch was removed before this picture was taken. Scale: this filter measures $11.4 \mathrm{~cm}$ by $11.4 \mathrm{~cm}$.

The 1-ply nominal filter, 2-ply nominal filter, and 2-ply nominal-absolute (sealed with Liquid Fusion) filter were tested for treatment capabilities against mock challenge water at Cal Poly (Figure 3.19, Figure 3.20, and Figure 3.21).

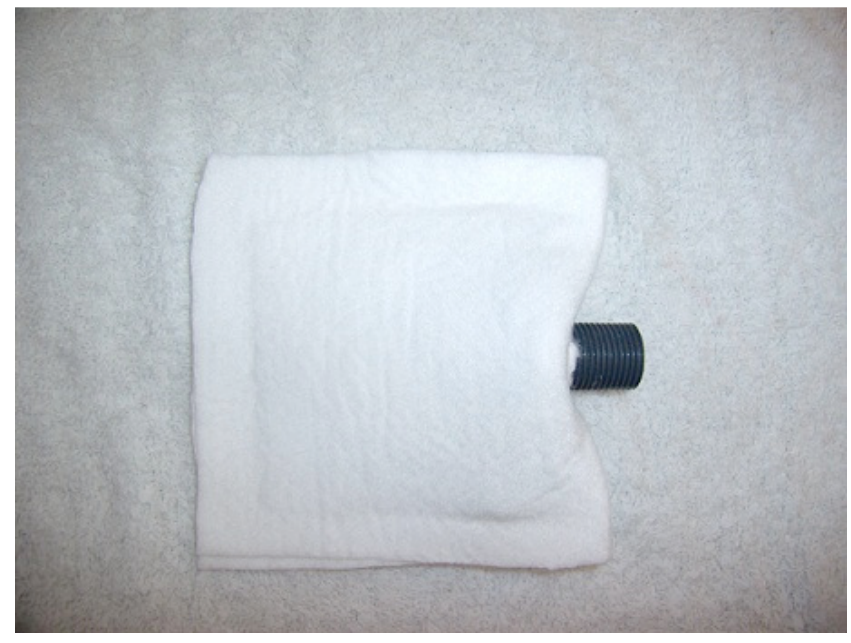

Figure 3.19: 1-ply nominal filter tested in experiment $H-1$. The plastic pouch was removed before this picture was taken. Scale: the large diameter bulkhead fitting protrudes $2.2 \mathrm{~cm}$ out of the filter. 


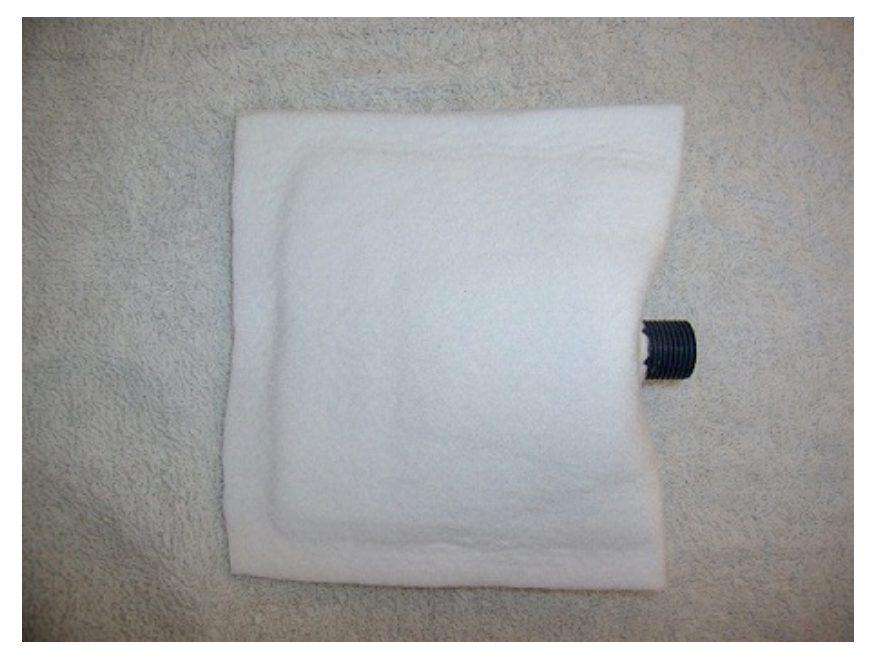

Figure 3.20: 2-ply nominal filter tested in experiment $\mathrm{H}-2$. The plastic pouch was removed before this picture was taken. Scale: the large diameter bulkhead fitting protrudes $2 \mathrm{~cm}$ out of the filter.

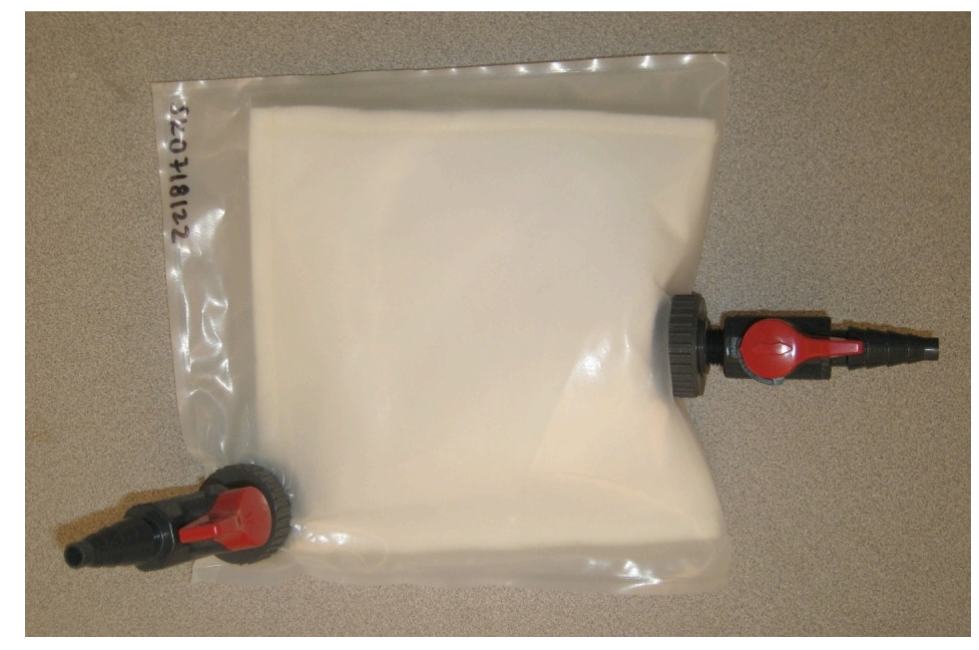

Figure 3.21: 2-ply nominal-absolute filter, sealed with Liquid Fusion, tested in experiment H-3. Scale: the learge diameter bulkhead fitting meausres $3.65 \mathrm{~cm}$ in diamter.

The 2-ply nominal-absolute filter was then tested in triplicate with U.S. EPA Challenge Water \#2 at BioVir Laboratories, Inc. in Benicia, California (Figure 3.22). A T-fitting was placed in the tubing between the pinch clamp and the filter. A tube with pinch valve descended from the $\mathrm{T}$ to a cubitainer. This was used to collect the sample of bag 
effluent-filter influent. All BioVir samples were composites collected continuously during the filter operation.

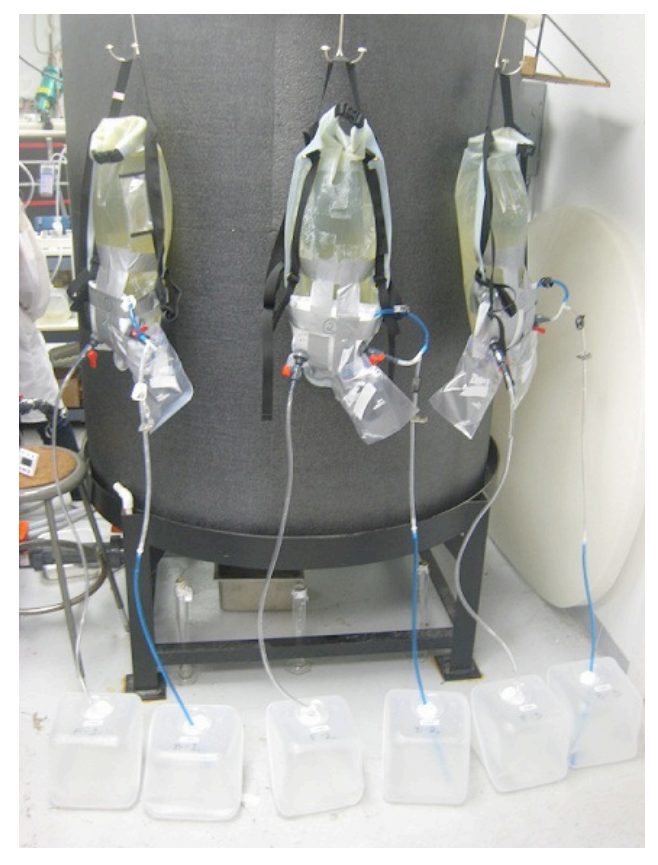

Figure 3.22: Testing in triplicate at BioVir Laboratories with composite effluent collected in cubitainers. Scale: the tubing measures $0.75 \mathrm{~cm}$ in diameter. The sandwich bags hanging below the waterbags were taped in place to catch any leaks from the seals of the filter pouches.

\subsection{Experimental Design}

The research performed can be divided into two primary kinds of experiments: (1) design experiments - to determine the most effective and durable filter design as well as the most apt placement of the filter on the waterbag, and (2) U.S. EPA Challenge Water experiments - to test the performance of the filters against the Test Water \#2 and to observe the filters' performance regarding bacteria and cyst removal. Experimental objectives, test water preparation, and experimental procedures can be found in the following sections. The experimental plan is detailed in Figure 3.23. 


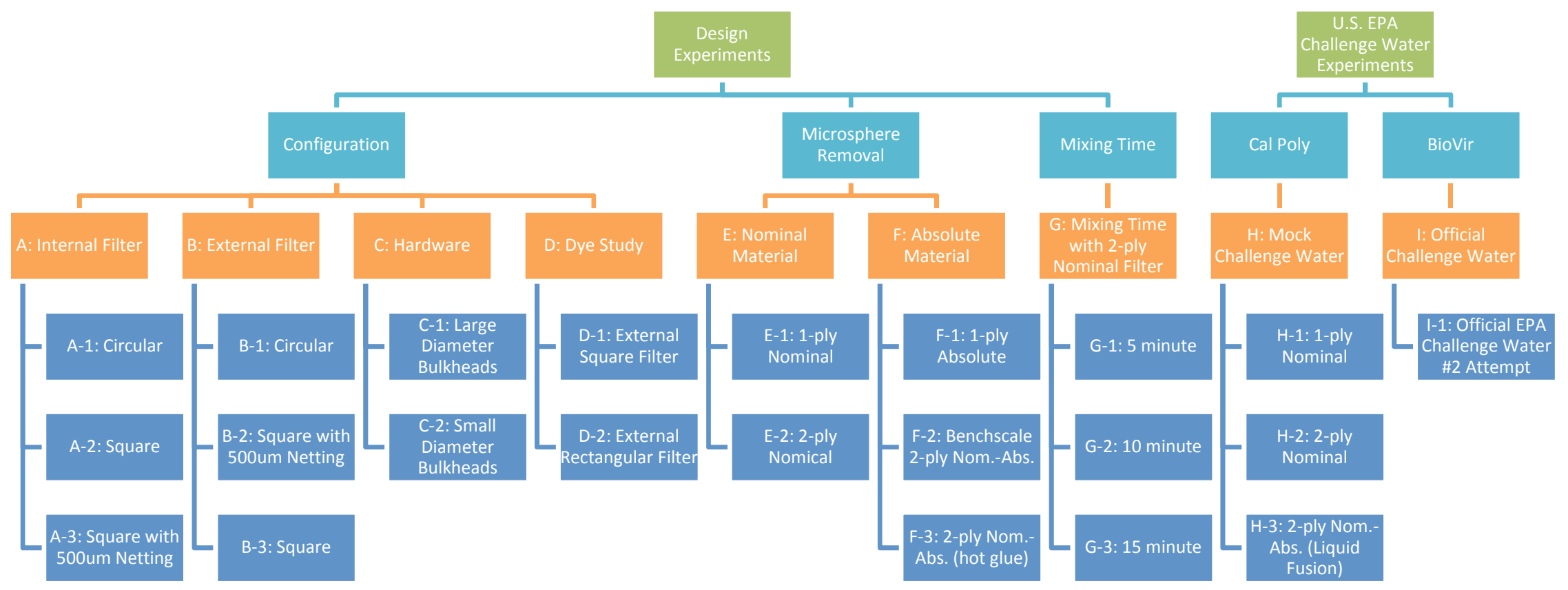

Figure 3.23: Experiments performed. Filters for experiments A-1 through D-2 were made of nominal felt material. For the other experiments, the cloth type is specified in the diagram. 


\subsubsection{Experimental Plan}

The twenty-two experiments are described herein (Figure 3.23), each with their purpose. Configuration experiments with both internal and external filters (A-1 through A-3 and B-1 through B-3) were conducted to determine a preferred filter geometry and placement of the filter on the waterbag. Configuration experiments regarding hardware (C-1 and C2) were performed to determine the preferred bulkhead fittings to be used in filter construction. Configuration experiments regarding flow patterns using a dye tracer (D-1 and D-2) were used to determine how water actually flowed through the material. Microsphere removal experiments (E-1, E-2, and F-1 through F-3) helped determine the removal capabilities of various filter designs and over a range of flow rates. Mixing time experiments (G-1 through G-3) were used to optimize treatment prior to filtration. Mock challenge water experiments ( $\mathrm{H}-1$ through $\mathrm{H}-3)$ were conducted to determine which filter and flow rate was capable of meeting the bacteria and cyst removal requirements of the U.S. EPA Guide Standard and Protocol for Testing Microbiological Water Purifiers. Experiment I-1 was the U.S. EPA Challenge Water \#2 trial at BioVir Laboratories using bacterial, viral, and cyst challenges. The experiments and rationale are explained in further detail in the following sections. General water preparation and experimental procedures for the experiments in Figure 3.23 are detailed in the following section.

\subsubsection{Water Preparation}

Tap water served as the source water for all experiments. For all design experiments (A1 through G-3), non-aerated tap water was used as chlorine residual was not measured in these experiments. For all U.S. EPA challenge water experiments (H-1 through I-1), aerated tap water was used since chlorine residual was a monitored chemical constituent 
in these experiments. Tap water was aerated overnight in order to promote dechlorination and remove all chlorine that could interfere with experimental results. The chlorine residual was checked before water was used for experiments.

Test water used for all experiments contained A2 Fine Test Dust (ISO 12103-1; purchased from Powder Technology, Inc., Burnsville, MN) to increase turbidity and sea salts (Instant Ocean, Cincinnati, OH) to adjust total dissolved solids (TDS). The water prepared for U.S. EPA challenge water experiments was also chilled down to $6^{\circ} \mathrm{C}$, and contained humic acid (Alfa Aesar, Ward Hill, Mass., Stock \#41747, Lot \#D25S004) to increase total organic carbon (TOC) as well as K-12 E. coli (initially prepared by Alice Hamrick in the Cal Poly Biology department, further grown in the Environmental Engineering lab) to increase biological cell concentration. The test water for experiments E-1 through $\mathrm{H}-3$ also contained $3.1 \mu \mathrm{m}$ diameter fluorescent green microspheres (Microgenics Corporation, purchased from Thermo Scientific, Catalog \# G0300) with an excitation wavelength of $468 \mathrm{~nm}$ and an emission wavelength of $508 \mathrm{~nm}$. The microspheres were in a suspension with a concentration of $6.08 \times 10^{8}$ spheres $/ \mathrm{mL}$.

In design experiments A-1 through E-2 (except D-1 and D-2), the turbidity of the test water ranged between $400 \mathrm{NTU}$ and $500 \mathrm{NTU}$. The test water used in design experiments F-1 through G-3 as well as U.S. EPA challenge water experiments H-1 through I-1 had initial turbidities between 40 NTU and 60 NTU, which met the $>30$ NTU turbidity requirement of the U.S. EPA Challenge Test Water \#2 recipe.

For experiments A-1 through G-3, source water was added to a 75-L RubberMaid ${ }^{\circledR}$ refuse container (hereinafter referred to as a large drum) with a ball-valve outlet (Figure 3.24) 
in order to make the test water mixture. One liter of source water was removed from the large drum and placed in a glass blender. Pre-weighed amounts of specific ingredients were added to the one liter of source water and mixed using an Osterizer ${ }^{\circledR}$ glass blender (on pulse setting) for one minute. The blender was used to ensure adequate mixing of the powdered ingredients. The blended $1-\mathrm{L}$ of source water and various ingredients was then poured back into the large drum. A Flotec ${ }^{\circledR}$ submersible sump pump (model FP0S2450A-08, 1/3 HP) was used to completely mix the test water for 30 minutes (Figure 3.25). Once mixing was complete, the sump pump was turned off and a waterbag was filled for the experiment. If greater than five minutes elapsed between turning the sump pump off and needing to fill another waterbag, the sump pump was turned on and the test water was mixed for an additional five minutes.

Figure 3.24: Large drum used to mix test water (Herzog, 2011). 


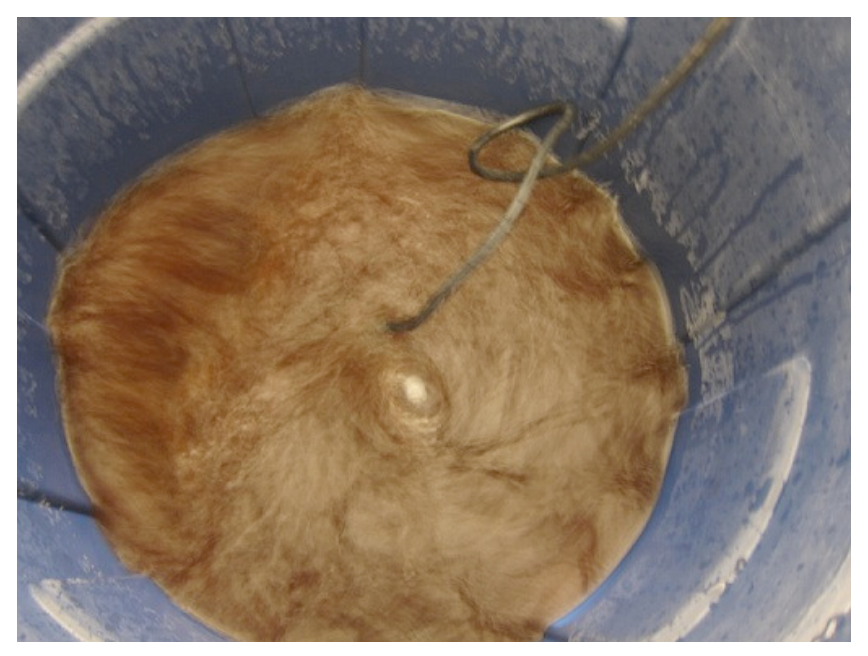

Figure 3.25: Test water being mixed with a submersible sump pump.

For experiments H-1, H-2, and H-3, 15 L of chilled, de-chlorinated tap water was used as the source water. Source water was dechlorinated, chilled, and mixed into test water in 5 gallon buckets. One L of source water was removed from the 5 gallon bucket and placed in a glass blender. Pre-weighed amounts of specific ingredients were added to the 1-L of source water and mixed using an Osterizer ${ }^{\circledR}$ glass blender (on pulse setting) for one minute. The blended one liter of source water and various ingredients was then poured back into the 5 gallon bucket. The bucket was placed on a stir plate and mixed for 30 min with a magnetic stir-bar. Completely mixed test water was then poured into a waterbag for the experiment.

\subsubsection{Experimental Testing Procedures}

After the waterbags were filled with test water from either the large drum or 5 gallon bucket, a PŪR ${ }^{\circledR}$ sachet was added to the untreated water, the bag was closed, and each bag was mixed using a standardized mixing method. For experiments A-1 to E-2, bags were hung from a wooden dowel roughly four feet off the ground and twisted $180^{\circ}$ from side-to-side for the specified mixing time (Figure 3.26). More head was needed for 
experiments F-1 to H-3, so bags were hung from a wooden dowel roughly six feet off the ground and twisted $180^{\circ}$ from side-to-side for the specified mixing time. During experiments F-1 and F-3, filters were placed on the floor in order to produce flow. All flow versus head data is available in Appendix C.

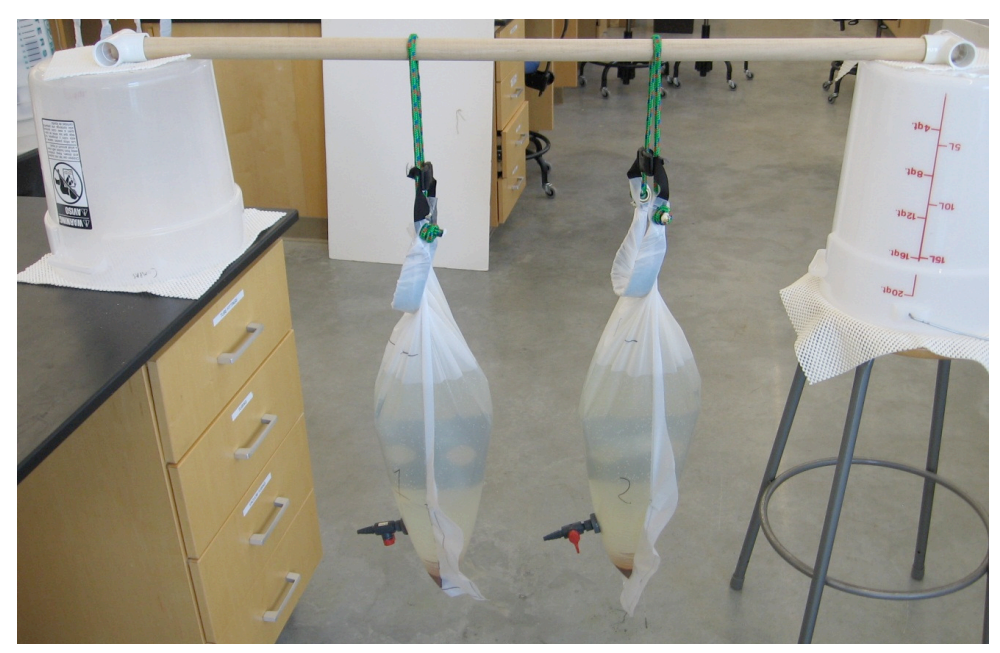

Figure 3.26: Set-up for experiments A-1 to E-2 (Herzog, 2011).

Treated, filtered effluent was collected in 1-L beakers. Samples were taken from the beakers to perform water quality testing. Residual water in the waterbag after testing as well as floc formed during treatment was poured down the drain. The rad-tab valves (Figure 3.21) were used to control flow both into the filter and out of the filter pouch. The waterbag was filled with tap water initially to allow for the red tab valves to be set in the required location for proper flowrate required for the experiment. The pinch valve, used to prevent untreated water from entering the filter, was located between the waterbag outlet and filter pouch inlet. The pinch valve was closed while the waterbag was filled and the water was treated with a PŪR ${ }^{\circledR}$ sachet. After treatment, the pinch valve was opened and water flowed into the filter pouch. 
A metronome was used to achieve consistent mixing at 100 beats per minute (bpm) through all experiments. Regarding bag rotation during mixing, one beat represented a complete $180^{\circ}$ twist of the waterbag. Each bag was mixed constantly for five minutes.

The required chlorine contact time for $\mathrm{PUR}^{\circledR}$ is $30 \mathrm{~min}$. Therefore, all bags were allowed to settle, undisturbed, for 30 min before samples were taken. Note that Procter $\&$ Gamble's instructions for PŪR ${ }^{\circledR}$ require 25 min of settling, not 30 min as was used during all experiments except experiment I-1, because the 5 min mix is included in the total chlorine contact time of $30 \mathrm{~min}$.

\subsection{Water Quality Measurements}

Both non-microbiological and microbiological variables were monitored in the experiments. The following section describes the water quality methods used.

\subsubsection{Non-Microbiological Variables}

Non-microbiological water quality constituents were turbidity, temperature, $\mathrm{pH}$, and chlorine residual.

\subsubsection{Turbidity}

A HACH 2100P Portable Turbidimeter (Catalog \#46500-00, Lot\#L7002) was used to measure turbidity of all samples. The turbidimeter was calibrated before every experiment with StablCal ${ }^{\circledR}$ Stabilized Formazin Turbidity Standards (sealed vials of $<0.1$ NTU, 20 NTU, 100 NTU, and 800 NTU). During experiments, a sample was collected in a turbidimeter vial, the vial was capped, the vial exterior was dried with a soft cloth, and the exterior was polished with a drop of silicon oil. After analysis, the vials were rinsed with deionized water and placed upside down on a paper towel to dry before being used 
to collect another sample. This turbidity measurement method is in accordance with the U.S. EPA Method 180.1 criteria for reporting drinking water analysis (HACH Company 2010).

\subsubsection{Temperature}

Temperature of the pre-treatment wastewater was measured with a classic mercury thermometer. Temperature measurements were taken immediately before the waterbags were filled, directly from the bucket the raw water was mixed in.

\subsubsection{3 pH}

The $\mathrm{pH}$ of treated, filtered effluent was measured with a Mettler Toledo Seven Easy $\mathrm{pH}$ meter (with a $\mathrm{pH}$ range from 0 to 14 and a resolution of 0.01 ). The $\mathrm{pH}$ meter was calibrated before every experiment using Fisher Scientific pH 4, 7, and 10 buffer solutions. $\mathrm{pH}$ samples from both pre-treatment and post-treatment water were collected in $250-\mathrm{mL}$ beakers. $\mathrm{pH}$ measurements were allowed to equilibrate before readings were recorded.

\subsubsection{Chlorine Residual}

A HACH DR/890 Colorimeter (Catalog \#4847000) and HACH DPD Free Chlorine Reagent powder pillows for $10 \mathrm{~mL}$ samples (Catalog \#2105569) were used to measure free chlorine residual of samples. Ten-mL samples were collected in glass sample vials, a single reagent pillow packet was added to the samples, the vials were capped for mixing, and the exterior of the vials was polished with a soft cloth. Vials were mixed by continuous swirling and inversions for approximately 20 seconds and analyzed immediately after mixing. For analysis of samples, the HACH Colorimeter Program 9 
was used. This program was selected because it has a method detection limit of 0.02 $\mathrm{mg} / \mathrm{L}$ and a readable chlorine residual range of 0 to $2.00 \mathrm{mg} / \mathrm{L}$. The U.S. EPA has accepted this method for reporting drinking water analysis (HACH Company, 2010). This method is also equivalent to Standard Method 4500-Cl G (HACH Company, 2000). As the same Colorimeter and Program was used, the calibration curve developed by Margaret Herzog for her thesis was used to determine chlorine content of samples instead of developing a new one (Herzog, 2011).

\subsubsection{Microbiological Variables}

Microbiological water quality constituents included E. coli, total coliform bacteria, and 3.1- $\mu \mathrm{m}$ diameter microspheres, which are a surrogate for parasite cysts.

\subsubsection{E. coli and Total Coliform Bacteria}

IDEXX Colilert $^{\circledR}$ 24-hour coliform/E. coli reagent and Quanti-Tray ${ }^{\circledR} / 2000$ methods were used to measure both total coliform bacteria and E. coli. Samples of source water; treated, pre-filtration; and treated, post-filtration were collected in sterile glass beakers and diluted with sterile DI water, if needed, in order for samples to be in the detectable concentration range of the Colilert method. Samples were then poured into $100-\mathrm{mL}$ sterile polypropylene plastic bottles, each containing one 10-mg sodium thiosulfate tablet. After the sodium thiosulfate tablet was dissolved, one Colilert ${ }^{\circledR}$ snap pack (exclusively for $100-\mathrm{mL}$ water samples) was added to the sample, and the bottle was closed and shaken to dissolve the reagent. Each sample plus Colilert ${ }^{\circledR}$ reagent was poured into an IDEXX Quanti-Tray ${ }^{\circledR} / 2000$, sealed with a Quanti-Tray ${ }^{\circledR}$ sealer, and incubated at $37^{\circ} \mathrm{C}$ for 24 hours. After 24 hours, the number of positive tray cells was determined. Yellow cells indicated positive results for total coliform bacteria; both yellow and fluorescent cells 
indicated positive results for $E$. coli. Fluorescence of each sample was determined using a portable, long-wave UV light lamp (Blak-Ray Lamp, Model UVL-21, Serial \#3418). Lastly, based on the number of positive cells observed, the most probable number (MPN) of bacteria was determined using a Colilert ${ }^{\circledR}$ MPN table (IDEXX, 2012).

\subsubsection{Microspheres}

A standard averaging technique was followed when determining the log removal of microspheres in an experiment. This method was followed by ATS Labs when Procter \& Gamble performed a U.S. EPA Challenge Water test in January 2008. This method was further confirmed as common practice with Dr. Danielson, Laboratory Director, BioVir Laboratories (R. Danielson, personal communication, December 16, 2011).

An Olympus BX-41 epifluorescence microscope was used to enumerate the removal of microspheres in the samples. The microscope was equipped with a mercury-vapor lamp, filter set for fluorescent observation, and phase-contrast objective lenses.

A $10-\mathrm{mL}$ sample was collected and vacuum-filtered through a $25-\mathrm{mm}$ diameter, $0.22-\mu \mathrm{m}$ pore size Millipore ${ }^{\circledR}$ filter. The 25 -mm diameter filter was placed on a microscope slide, a cover slip was placed over the filter, and clear finger nail polish was placed on all four corners of the cover slip to fix the filter and cover slip in place.

In preparation of viewing the slide with the microscope, the computer, microscope, burner, Optiscan unit, and camera were turned on to warm up for a few minutes. Filter wheel (FW) 1 was set to position 6 and FW 2 was set to position 5. The turret on the microscope was set to position 1 (bright field) for initial focusing. Once focused, the 
turret was set to position 2(FITC filter), the shutter was turned on with the keypad, and the shutter was opened on the microscope.

To enumerate the microspheres in a sample, the area of the field of view (FOV) was first determined with a hemacytometer (Figure 3.27). The effective diameter of the 25-mm diameter filter was determined using calipers. The effective diameter was the area that water passed through. No water passed through the periphery of the filter where the vacuum filtration funnel covered the outside edge of the filter. The effective diameter was then used to calculate the usable area of the $25-\mathrm{mm}$ diameter filter. Both the area of the FOV and the usable filter area were recorded for later use.

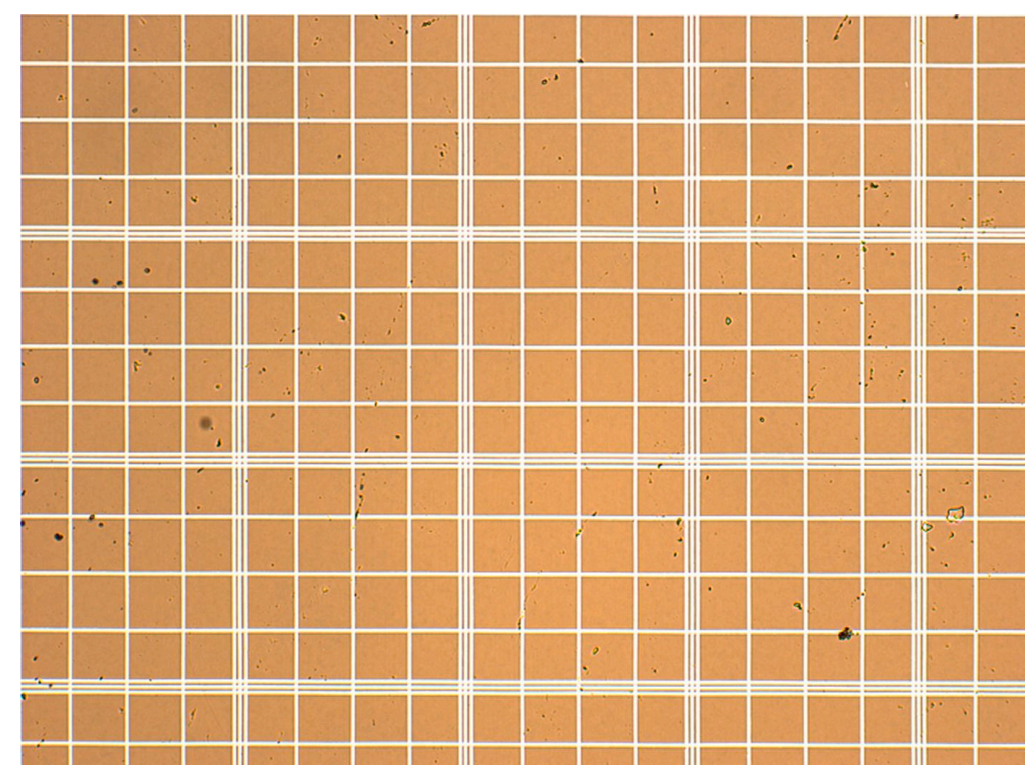

Figure 3.27: Hemacytometer used to determine the area of the FOV, observed at 100X total magnification.

Ten random FOVs were captured and the number of microspheres in each FOV was counted and recorded (Figure 3.28). 


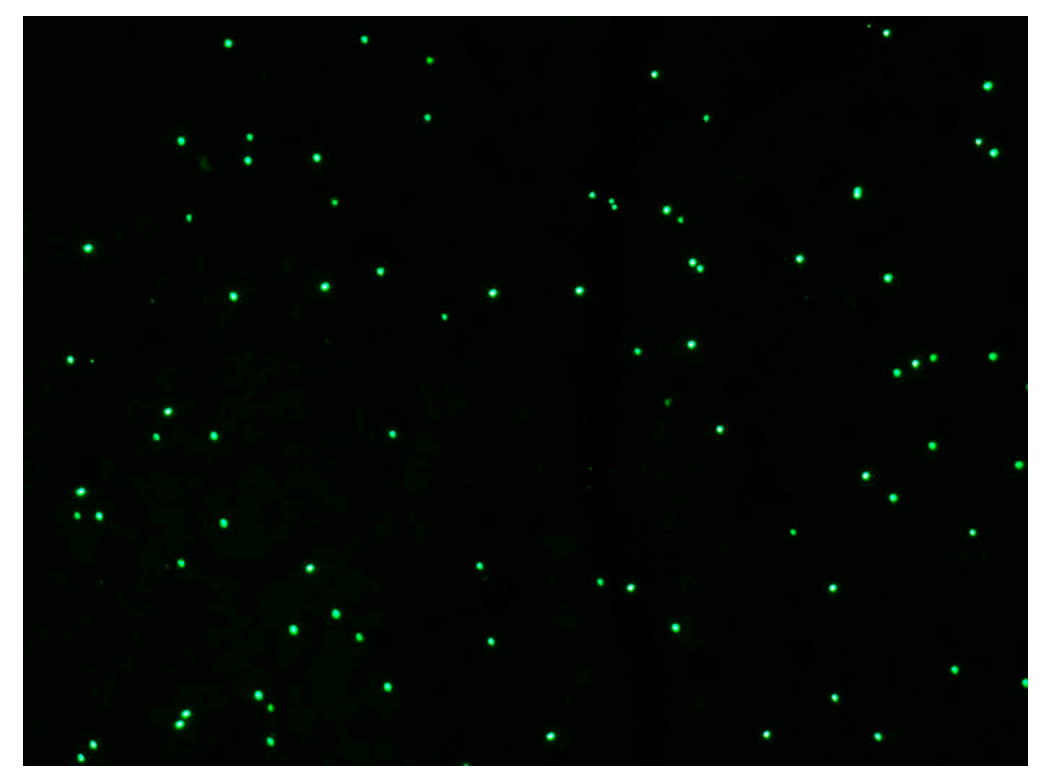

\section{Figure 3.28: An FOV at 100X total magnification.} The green dots are the fluorescent microspheres.

The concentration in each sample was determined using the following equation:

$\frac{\text { total \# spheres in } 10 \mathrm{FOV}}{\text { filtered sample volume }(\mathrm{L})} * \frac{\text { usable area of Millipore filter }\left(\mathrm{mm}^{2}\right)}{\text { FOV area }\left(\mathrm{mm}^{2}\right) * 10 \mathrm{FOV} \text { counted }}=\frac{\# \text { spheres }}{L}$

Sphere concentration was determined for raw/untreated, pre-filter, and post-filter samples. This allowed the removal capabilities of the filter to be determined. The log of each concentration was then taken to determine the log removal capability of the filter.

\subsection{Design Experiments}

Design experiments included eighteen individual experiments which tested three general areas: (1) configuration, (2) microsphere removal, and (3) mixing time. The primary objective of these experiments was to identify the optimum filter cloth, filter shape, filter placement on the waterbag, hardware used in filter manufacturing, and flowrate through the filter that produced final treated effluent with adequate log removal of bacteria, viruses, and protozoan cysts and well as turbidity of $<5$ NTU. 


\subsubsection{Water Preparation for Design Experiments}

The design experiments followed the general water preparation procedures detailed in Section 3.2 with the exception of experiment F-2. For the bench-scale 2-ply nominalabsolute filter tested in experiment F-2, 1-L of tap water was dosed with $1.65 \mu \mathrm{L}$ of spheres and mixed for $30 \mathrm{~min}$ using a magnetic stir bar and stir plate. Twenty $\mathrm{mL}$ of the test water was filtered through the bench-scale 2-ply nominal-absolute filter with the vacuum pump assembly. The filtrate was collected in a flat-bottomed test tube inside the vacuum flask. The filtrate was then analyzed for microspheres. Several test variables and information regarding design experiments can be found in Table 3.1. 
Table 3.1: Design experiment information (includes test water variables, ingredient amounts, and mixing time)

\begin{tabular}{|c|c|c|c|c|c|c|c|}
\hline Experiment & $\begin{array}{c}\text { Primary } \\
\text { Variable(s) }\end{array}$ & $\begin{array}{l}\text { Source } \\
\text { Water }\end{array}$ & $\begin{array}{c}\text { A2 Fine Test } \\
\text { Dust } \\
\text { Amount } \\
\text { Added per } \\
10 \text { L }(\mathrm{g}) \\
\end{array}$ & $\begin{array}{c}\text { Instant Ocean } \\
\text { Amount Added } \\
\text { per } 10 \text { L (g) }\end{array}$ & $\begin{array}{c}\text { Humic Acid } \\
\text { Amount } \\
\text { Added per } 10 \\
\text { L }(\mathrm{g})\end{array}$ & $\begin{array}{l}\text { Mixing } \\
\text { Speed } \\
\text { (beats per } \\
\text { minute) }\end{array}$ & $\begin{array}{c}\text { Mixing } \\
\text { Time } \\
\text { (min) }\end{array}$ \\
\hline $\begin{array}{l}\text { A-1 to } 3, B-1 \text { to } \\
3 \text {, and C-1 to } 3\end{array}$ & $\begin{array}{c}\text { Turbidity and } \\
\text { filter life }\end{array}$ & Tap water & 5 & 10 & None & 100 & 5 \\
\hline D-1 \& D-2 & $\begin{array}{c}\text { Use of filter } \\
\text { area }\end{array}$ & $\begin{array}{l}\text { Tap water } \\
\text { with } \\
\text { Rhodamine } \\
\text { dye }\end{array}$ & -- & -- & -- & -- & -- \\
\hline E-1 \& 2 & $\begin{array}{c}\text { Microsphere } \\
\text { removal }\end{array}$ & Tap water & $\begin{array}{l}5 \& 0.5, \\
\text { respectively }\end{array}$ & 10 & 0.4 & 100 & 5 \\
\hline F-1 to 3 & $\begin{array}{c}\text { Microsphere } \\
\text { removal }\end{array}$ & Tap Water & 0.5 & 10 & 0.4 & 100 & 5 \\
\hline G-1 to 3 & $\begin{array}{l}\text { Waterbag } \\
\text { mixing time }\end{array}$ & Tap water & 0.5 & 10 & 0.4 & 100 & 5 \\
\hline
\end{tabular}




\subsubsection{Experimental Procedures for Design Experiments}

The water quality constituents measured during each experiment are listed in Table 3.2.

Turbidity was measured in all experiments except for D-1 and D-2 as these were dye study experiments. No design experiments included the measurement of microbiological constituents. However, experiments E-1 through F-2 included the measurement of removal of microspheres by the filters.

Table 3.2: Variables measured during the design experiments

\begin{tabular}{ccccc}
\hline \multirow{2}{*}{ Experiment } & \multicolumn{4}{c}{ Variables Measured } \\
\cline { 2 - 5 } & Turbidity & $\begin{array}{c}\text { Flow through } \\
\text { filter cloth }\end{array}$ & $\begin{array}{c}\text { Microsphere } \\
\text { removal }\end{array}$ & Temperature \\
\hline A-1 & $\mathrm{X}$ & & & \\
A-2 & $\mathrm{X}$ & & & \\
B-1 & $\mathrm{X}$ & & & \\
B-2 & $\mathrm{X}$ & $\mathrm{X}$ & & \\
B-3 & $\mathrm{X}$ & & \\
C-1 & $\mathrm{X}$ & & & \\
C-2 & $\mathrm{X}$ & & & \\
D-1 & & $\mathrm{X}$ & \\
D-2 & & $\mathrm{X}$ & \\
E-1 & $\mathrm{X}$ & & $\mathrm{X}$ & \\
E-2 & $\mathrm{X}$ & & $\mathrm{X}$ & \\
F-1 & $\mathrm{X}$ & $\mathrm{X}$ & $\mathrm{X}$ \\
F-2 & $\mathrm{X}$ & $\mathrm{X}$ & $\mathrm{X}$ \\
F-3 & $\mathrm{X}$ & $\mathrm{X}$ & $\mathrm{X}$ \\
G-1 & $\mathrm{X}$ & & $\mathrm{X}$ & $\mathrm{X}$ \\
G-2 & $\mathrm{X}$ & & $\mathrm{X}$ & $\mathrm{X}$ \\
G-3 & $\mathrm{X}$ & & & \\
\hline
\end{tabular}


In the mixing time experiments, an initial $5 \mathrm{~min}$ mix was performed followed by a $5 \mathrm{~min}$ resting period. This cycle continued until the desired mixing time was achieved. All bags were allowed to settle for $30 \mathrm{~min}$ after their respective mixing times were complete.

For the dye studies performed in experiments D-1 and D-2, the rhodamine dye-water mixture used was a 100X dilution of rhodamine dye with a density of approximately 1

$\mathrm{g} / \mathrm{mL}$. Three $\mathrm{mL}$ of the diluted rhodamine dye was injected into the tubing leading from the waterbag to the filter during each trial of experiments D-1 and D-2.

\subsection{U.S. EPA Challenge Water Experiments}

After determining the optimum filter cloth and design, the next step was to test various filters against U.S. EPA Challenge Water (Test Water \#2) to determine which filter was most effective. Three experiments tested the performance of various filters against the U.S. EPA Challenge Water (Test Water \#2) recipe. The first experiment performed, experiment $\mathrm{H}-1$, tested the 1-ply nominal filter to ensure that proper treatment was not possible with this design, as described in Chapter 4. The second experiment performed, experiment $\mathrm{H}-2$, tested the 2-ply nominal filter to ensure that proper treatment was not possible with this design even at a very low flowrate. The next experiment performed, experiment $\mathrm{H}-3$, tested the 2-ply nominal-absolute (liquid fusion) filter to determine the greatest flowrate that could pass through the filter while still performing proper removal and treatment. Experiments $\mathrm{H}-1, \mathrm{H}-2$, and $\mathrm{H}-3$ were used to determine which filter was to be tested during the last U.S. EPA Challenge Water experiment (I-1). The objective of experiment I-1 was to test the final filter design in triplicate against U.S. EPA Challenge Water (Test Water \#2) at BioVir Laboratories in Benicia, CA and confirm that the filter would perform adequate pathogen removals. 


\subsubsection{Water Preparation for Mock Challenge Water Experiments}

The test water for the U.S. EPA Challenge Water experiments was prepared in the same manner of the optimization experiments except that a few additional ingredients were added as well. The U.S. EPA Challenge Water (Test Water \#2) test water required additional modifications in that humic acid was required, the temperature was adjusted to near $4^{\circ} \mathrm{C}$, and $\mathrm{K}-12 \mathrm{E}$. coli was added to the test water. The temperature of the test water was lowered by storing the test water overnight in a $5.5^{\circ} \mathrm{C}$ refrigerator. Ice cubes were not added to the source water to further lower the temperature as they would add chlorine to the test water. Experiments $\mathrm{H}-1, \mathrm{H}-2$, and $\mathrm{H}-3$ did include $E$. coli and microspheres to mimic the Challenge Test Water \#2 recipe. When preparing to work with microorganisms, all glassware and dilution water was sterilized by autoclaving prior to use. Alice Hamrick of the Biological Sciences Department at Cal Poly grew and provided a stock K12 E. coli culture for use in the lab (A. Hamrick, personal communication, July 23, 2012). The original culture was grown in LB liquid growth medium and stored in a $30^{\circ} \mathrm{C}$ incubator between experiments. The $E$. coli concentration of the stock solution was estimated by measuring the optical density at $600-\mathrm{nm}$ of the solution using a UV/V spectrophotometer (an $\mathrm{OD}_{600}$ of 1.0 equates to a cell concentration of $8 \times 10^{8}$ cells $/ \mathrm{mL}$, website calculator used located at http://www.genomics.agilent.com/CalculatorPopupWindow.aspx?CalID=7). Once the absorbance was measured, a concentration could be estimated, and the required volume

of the solution to meet the $10^{7} / 100 \mathrm{~mL}$ bacterial initial concentration in the test water was pipetted into the test water. The experiment variables and information for the U.S. EPA Challenge Water tests can be found in Table 3.3. 
Table 3.3: U.S. EPA Challenge Water experiment information including test water variables, source water types, ingredient amounts, mixing speeds, and mixing lengths.

\begin{tabular}{|c|c|c|c|c|c|c|c|c|}
\hline Experiment & $\begin{array}{l}\text { Number of } \\
\text { Prototypes } \\
\text { Tested }\end{array}$ & $\begin{array}{c}\text { Output } \\
\text { Variable }\end{array}$ & $\begin{array}{l}\text { Source } \\
\text { Water }\end{array}$ & $\begin{array}{l}\text { A2 Fine Test } \\
\text { Dust Mass (g) } \\
\text { Added to } 15 \text { L }\end{array}$ & $\begin{array}{l}\text { Instant Ocean } \\
\text { Mass (g) } \\
\text { Added to } 15 \mathrm{~L}\end{array}$ & $\begin{array}{l}\text { Humic Acid } \\
\text { Mass (g) } \\
\text { Added to } 15 \\
\text { L } \\
\end{array}$ & $\begin{array}{l}\text { Mixing } \\
\text { Speed } \\
\text { (beats per } \\
\text { minute) }\end{array}$ & $\begin{array}{c}\text { Mixing } \\
\text { Time } \\
\text { (min) }\end{array}$ \\
\hline $\mathrm{H}-1$ & 1 & $\begin{array}{l}\text { Sphere } \\
\text { removal }\end{array}$ & $\begin{array}{l}\text { Aerated } \\
\text { tap } \\
\text { water }\end{array}$ & 0.5 & 15 & 0.6 & 100 & 5 \\
\hline $\mathrm{H}-2$ & 1 & $\begin{array}{l}\text { Sphere } \\
\text { removal }\end{array}$ & $\begin{array}{c}\text { Aerated } \\
\text { tap } \\
\text { water }\end{array}$ & 0.5 & 15 & 0.6 & 100 & 5 \\
\hline H-3 & 1 & $\begin{array}{l}\text { Water flowrate } \\
\text { through filter }\end{array}$ & $\begin{array}{l}\text { Aerated } \\
\text { tap } \\
\text { water }\end{array}$ & 0.5 & 15 & 0.6 & 100 & 5 \\
\hline $\mathrm{I}-1$ & 3 & None & \multicolumn{6}{|c|}{ Source water and ingredients prepared by BioVir Laboratories, Inc. } \\
\hline
\end{tabular}




\subsubsection{Experimental Procedure for Mock Challenge Water Experiments}

The goal of experiments H-1 and H-2 was to determine if the 1-ply nominal and 2-ply nominal filters could meet the pathogen removal requirements set forth in the U.S. EPA Guide Standard and Protocol for Testing Microbiological Water Purifiers (Table 2.1). The goal of experiment H-3 was to determine the proper flowrate through the 2-ply nominal-absolute filter capable of meeting the removal requirements set forth in the U.S. EPA Guide Standard and Protocol for Testing Microbiological Water Purifiers (Table 2.1). After the U.S. EPA Challenge Water (Test Water\#2) (Table 2.2) was prepared in a large bucket, a waterbag was filled with $10 \mathrm{~L}$ of test water, a PÜR ${ }^{\circledR}$ sachet was added, and the bag was mixed following the standard mixing procedure.

Additional variables were measured in experiments $\mathrm{H}-1, \mathrm{H}-2$, and $\mathrm{H}-3$ in addition to variables measured in the optimization experiments (Table 3.4). Turbidity, temperature, E. coli, total coliforms, chlorine residual, and microsphere removal were measured during these experiments.

Table 3.4: Variables measured during U.S. EPA Challenge Water experiments

\begin{tabular}{cccccccc}
\hline \multirow{2}{*}{ Experiment } & \multicolumn{3}{c}{ Non-Microbiological Variables } & \multicolumn{3}{c}{ Microbiological Variables } \\
\cline { 2 - 7 } & Turbidity & $\mathbf{p H}$ & Temp. & \multirow{2}{*}{ Flowrate } & $\begin{array}{c}\text { Total } \\
\text { Coliform }\end{array}$ & $\begin{array}{c}\boldsymbol{E} \text { c. } \\
\text { coli }\end{array}$ & $\begin{array}{c}\text { Microsphere } \\
\text { Removal }\end{array}$ \\
\hline $\mathrm{H}-1$ & $\mathrm{X}$ & & $\mathrm{X}$ & $\mathrm{X}$ & $\mathrm{X}$ & $\mathrm{X}$ & $\mathrm{X}$ \\
$\mathrm{H}-2$ & $\mathrm{X}$ & & $\mathrm{X}$ & $\mathrm{X}$ & $\mathrm{X}$ & $\mathrm{X}$ & $\mathrm{X}$ \\
$\mathrm{H}-3$ & $\mathrm{X}$ & & $\mathrm{X}$ & $\mathrm{X}$ & $\mathrm{X}$ & $\mathrm{X}$ & $\mathrm{X}$ \\
$\mathrm{I}-1$ & $\mathrm{X}$ & $\mathrm{X}$ & $\mathrm{X}$ & $\mathrm{X}$ & $\mathrm{X}$ & $\mathrm{X}$ & $\mathrm{X}$ \\
\hline
\end{tabular}




\subsubsection{Water Preparation at BioVir for Official Challenge Water Experiment}

BioVir staff prepared a $40 \mathrm{~L}$ batch of U.S. EPA Challenge Test Water \#2 with characteristics listed in Table 3.5.

Table 3.5: Characteristics of U.S. EPA Challenge Water \#2, prepared by BioVir staff (BioVir, 2012)

\begin{tabular}{cc}
\hline Variable & Value \\
\hline Volume & $40 \mathrm{~L}$ \\
$\mathrm{pH}$ & 9.1 \\
Chlorine & Non-Detect \\
TDS & $1450 \mathrm{mg} / \mathrm{L}$ \\
Turbidity & $33 \mathrm{NTU}$ \\
TOC & $12.6 \mathrm{mg} / \mathrm{L}$ \\
Temperature & $4^{\circ} \mathrm{C}$ \\
\hline$*$ Before Humic acid added
\end{tabular}

The Challenge Test Water was inoculated with challenge microorganisms and fluorescent microspheres before filling the prototypes. The microorganisms were the bacterium Escherichia coli (ATCC11229), MS2 coliphage (ATCC15597-B1), and fr coliphage (ATCC15767-B1) (BioVir, 2012). The microspheres were $3.1 \mu \mathrm{m}$ diameter fluorescent microspheres as a surrogate for Cryptosporidium oocysts (Duke Scientific Corp., Palo Alto, CA) (BioVir, 2012). The test water was stirred continuously with a magnetic stir bar atop a large stir plate after ingredient addition. The U.S. EPA Challenge Water was stirred continuously through experiment I-1 to ensure homogenization of the Test Water \#2 before filling each prototype.

\subsubsection{Experimental Procedure at BioVir for Official Challenge Water Experiment}

Prototypes were tested in triplicate in experiment I-1. The mixing and sampling procedures as well as the mixing, settling, disinfection, and filtration methods were the same for all three prototypes. All three prototypes were initially filled with tap water, 
each bag was closed via the dry-bag closure, and each bag was hung from a hook on the top of a large insulated tank (Figure 3.22) in order to calibrate the flowrate of water through the 2-ply nominal-absolute filter to $20 \mathrm{~mL} / \mathrm{min}$. Vinyl tubing was attached to the flow-control valve leaving the filter pouch. The tubing was inserted into autoclaved 1-L graduated cylinders placed directly beneath each prototype. The flow-control valves at both the entrance and the exit of the filter pouch were opened. A stopwatch was used to monitor elapsed time as water filled the graduated cylinder. The flow-control valves were adjusted until the proper $20 \mathrm{~mL} / \mathrm{min}$ flowrate was obtained. The remaining tap water was poured out of the prototypes, the black pinch valve was closed, and the vinyl tubing was removed to prepare for filling the prototypes with test water.

After test water preparation, the waterbags were filled and mixed on a staggered timetable in order to allow for an uninterrupted five minute mixing period for each bag. After being filled with test water, one PŪR ${ }^{\circledR}$ sachet was added to the prototype, the bag was closed via the dry-bag closure, and the bag was hung from a hook on the top of a large insulated tank (Figure 3.22). Each prototype was mixed for five minutes at 100 bpm (Table 3.3), and then allowed to settle and disinfect for 25 minutes before filtration through the 2-ply nominal-absolute filter used in this experiment (Note that this 25minute settling period comports with the PUR instructions. Thirty minutes was used in the previous experiments of this thesis.).

During the settling period, six cubitainers were placed. Two cubitainers were placed underneath each prototype to collect both the pre-filter and post-filter water samples over time. The vinyl tubing was rinsed with isopropyl alcohol before it was re-attached to the prototypes and placed into the cubitainers. The alcohol was allowed to evaporate prior to 
being used. After the 25-min settling and disinfection period had elapsed, the black pinch valve was opened, allowing treated water to enter the filter pouch. Both pre-filter and post-filter water samples were collected. The pre-filter sample flowrate was approximately $20-\mathrm{mL} / \mathrm{min}$. After the experiment was over, the collected water samples were poured from the cubitainers into labeled sterile plastic screw-top sample bottles and handed over to Biovir staff for further analysis (BioVir 2012). Each sample bottle contained the proper amount of sterile sodium thiosulfate to neutralize any residual disinfectant in the collected water (BioVir, 2012). The BioVir test report (Appendix D) described the sample handing and processing.

\subsection{Quality Control}

To determine the precision of results, quality control (QC) procedures were included in experiments. QC procedures included testing of a single prototype throughout the entirety of an experiment, taking multiple (split) constituent readings, taking duplicate samples, calibrating using a standard, and using a developed calibration curve.

For water quality, QC procedures were included in turbidity and chlorine residual measurements. When measuring turbidity, a sample was read multiple times by the turbidimeter and the measured values were averaged for use in data analysis. When measuring chlorine residual, a calibration curve developed by Margaret Herzog during her 2010-2011 research was used when measuring samples with the colorimeter (Herzog, 2011). 


\section{CHAPTER 4: RESULTS AND DISCUSSION}

This chapter includes the results and discussion of both the design and U.S. EPA Challenge Water experiments.

\subsection{Design Experiments}

During all design experiments, filters were tested for turbidity removal as well as clogging rate. The goal of these experiments was to produce a filter that met turbidity requirements while also having a usable lifetime of at least 12 full waterbag uses. The primary objective of the design experiments was to determine the best size, shape, material, and use of a filter that would meet both the WHO and Sphere Project emergency guidelines for water treatment. In order the meet the guidelines, water turbidity must be $<5 \mathrm{NTU}$ and free chlorine residual should be within $0.2-0.5 \mathrm{mg} / \mathrm{L}$ (The

Sphere Project, 2004; WHO, 2006). Three types of design experiments were performed: (1) configuration experiments regarding internal filters, external filters, hardware, and dye studies; (2) microsphere removal experiments to determine the capabilities of both the nominal and absolute material; and (3) mixing time experiments to determine the effect of various mixing times on flocculation and turbidity.

\subsubsection{Configuration Experiments A-1 to A-3: Internal Filters}

Several internal filters were tested to determine turbidity removal capabilities, usable lifetime, and visual appearance to the user. Circular, square, and square with $500-\mu \mathrm{m}$ netting filters were tested in experiments A-1, A-2, and A-3, respectively.

The circular filter design tested in experiment A-1 filtered $120 \mathrm{~L}$ of treated water (12 waterbag uses) without clogging and turbidity of effluent was consistently $<1.5$ NTU, 
meeting the $<5$ NTU requirement. However, the plastic jacket, included in the design to prevent settling flocs from gathering on the filter, caused a large amount of flocs to be caught in the jacket during the waterbag cleanout process, and thus this design was not further pursued. The caught floc also caused the filter to get dirty during the 12 uses as some of the floc that is traditionally rinsed out after use was trapped in the jacket and not removed (Figure 4.1). The plastic jacket around the internal filter also prevented all floc from being removed from the waterbag during the waterbag cleanout process, causing the waterbag and filter to appear dirty in subsequent uses (Figure 4.2).

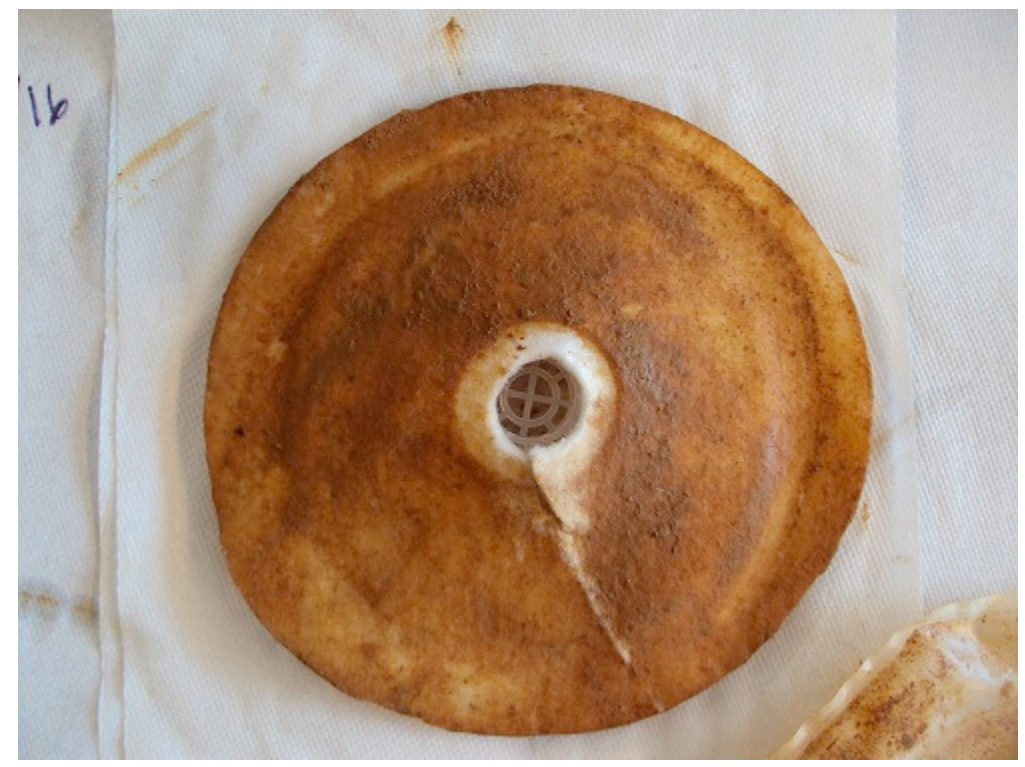

Figure 4.1: Circular filter after 12 uses, note the thick layer of floc on the filter cloth. Scale: the hole in the center is $2.22 \mathrm{~cm}$ in diameter. 


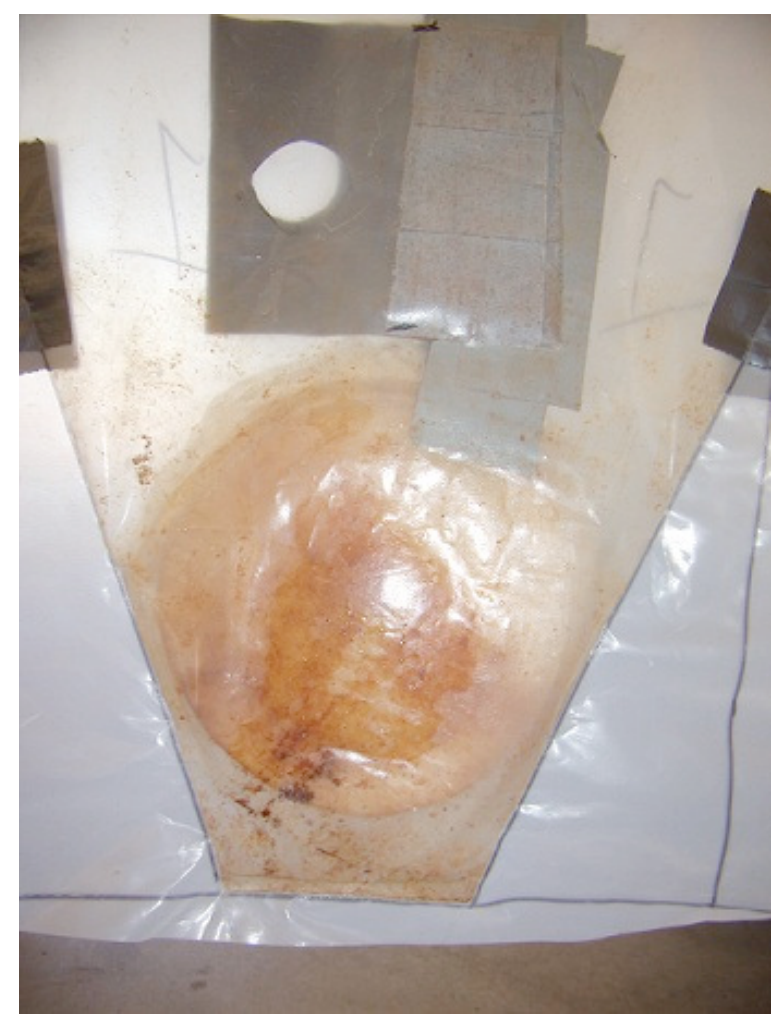

Figure 4.2: Floc caught in cone of waterbag after it had been cleaned.

The square filter design tested in experiment A-2 filtered $100 \mathrm{~L}$ of treated water (10 waterbag uses) before clogging and turbidity of the effluent was consistently $<5$ NTU. This is likely because the square filter had less surface area available for filtration than the circular filter. For experiment A-3, multiple layers of 500- $\mu$ m netting were glued to the outside of a square filter. The netting was added to reduce the amount of flocs removed from the effluent by the filter cloth, thereby reducing the amount of flocs that clogged the pores of the filter cloth. The square filter with $500-\mu \mathrm{m}$ netting tested in experiment A-3 did not clog after 12 uses and effluent turbidity met the $<5$ NTU requirement. Thus, the addition of the netting increased the usable life of the square filter by keeping the filter cloth cleaner. 
Since both circular and square filters accumulated floc on the exterior of the filter, it was determined that an internal filter would not be pursued as all filters tested were not visually appealing and could deter the user from continued use of the waterbag. An internal filter would also not allow for a simple exchange of an old filter for a new filter by the user.

\subsubsection{Configuration Experiments B-1 to B-3: External Filters}

Several external filters were tested to determine turbidity removal capabilities, usable lifetime, and visual appearance to the user. Circular, square with 500- $\mu \mathrm{m}$ netting, and square filters were tested in experiments B-1, B-2, and B-3, respectively.

The circular filter tested in experiment B-1 was only tested for 5 waterbag uses as the filter pouch could not be properly attached to the waterbag to prevent raw, untreated water from entering the filter pouch. Also, the weight of the filter pouch filled with water put too much strain on the bulkhead fitting attaching the filter pouch to the waterbag during the mixing step, causing the bulk head fitting to rip out of the waterbag.

The square filter with $500-\mu \mathrm{m}$ netting tested in experiment B-2 was used for 12 waterbag uses without clogging and effluent turbidity was consistently $<1.5 \mathrm{NTU}$, meeting the $<5$ NTU requirement. As described in Section 3.2, water flowed from the waterbag into the filter pouch, through the 500- $\mu \mathrm{m}$ netting and filter cloth, and into the internal chamber of the filter, where it flowed out as effluent. Due to the floc being filtered out on the external side of the filter, this filter also became quite soiled after 12 uses (Figure 4.3). It was assumed that the dirty filter could deter the user from continued use of the waterbag, so the flow of water was reversed in experiment B-3. 


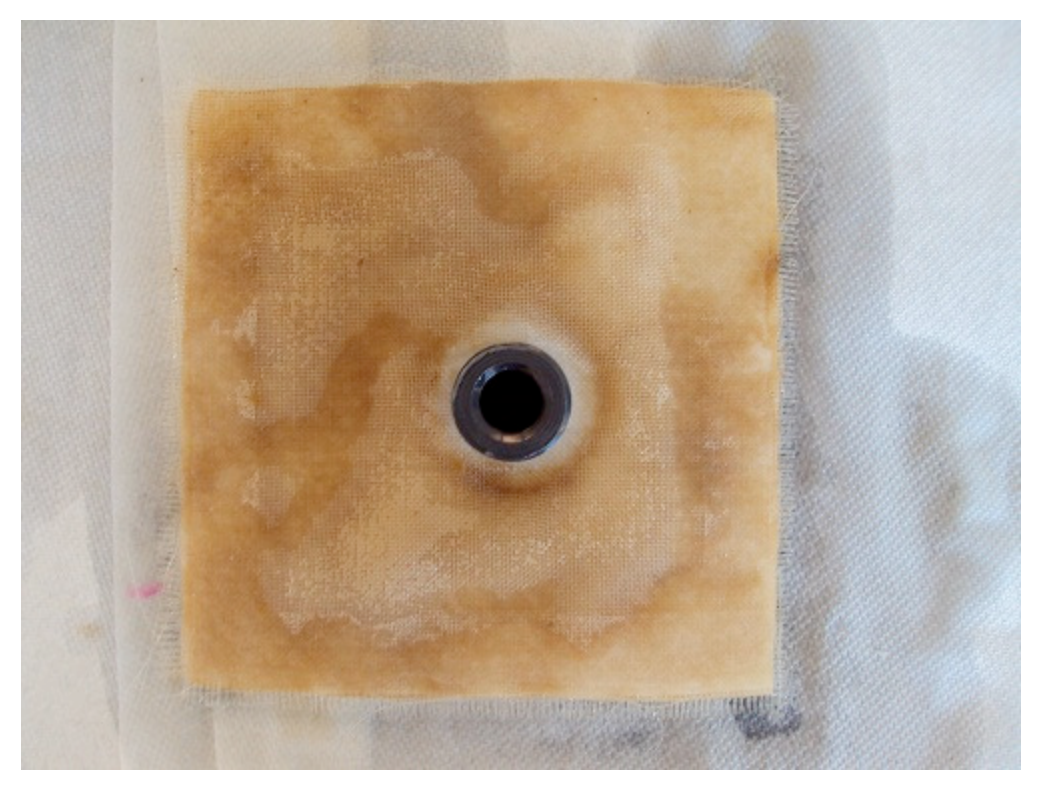

Figure 4.3: Square filter with 500- $\mu \mathrm{m}$ netting after 12 uses. Scale: the large diameter bulkhead fitting is $2.22 \mathrm{~cm}$ in diameter.

The square filter tested in experiment B-3 was used for 12 waterbag uses and effluent turbidity was consistently $<1.5 \mathrm{NTU}$, meeting the $<5 \mathrm{NTU}$ requirement. As noted in Section 3.2, water flowed from the waterbag into the internal chamber of the filter, through the filter cloth, and collected in the filter pouch where it flowed out as effluent. This design was much more aesthetically pleasing to the user as the floc was captured inside the filter and not visible to the user (Figure 4.4). Even after 12 uses, the filter still appears fairly clean externally (Figure 4.5). 


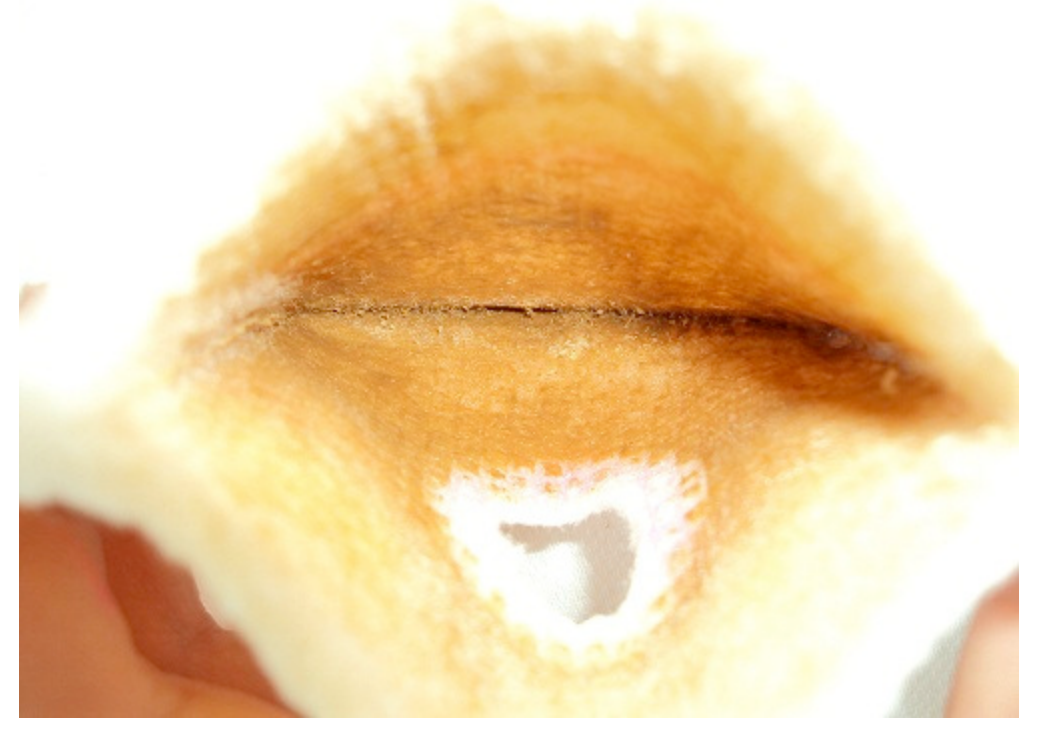

Figure 4.4: Floc caught in the internal chamber of the square filter tested in experiment B-3 after 12 uses. Scale: the hole in the lower half of the picture is $\mathbf{2 . 2 2}$ $\mathrm{cm}$ in diameter.

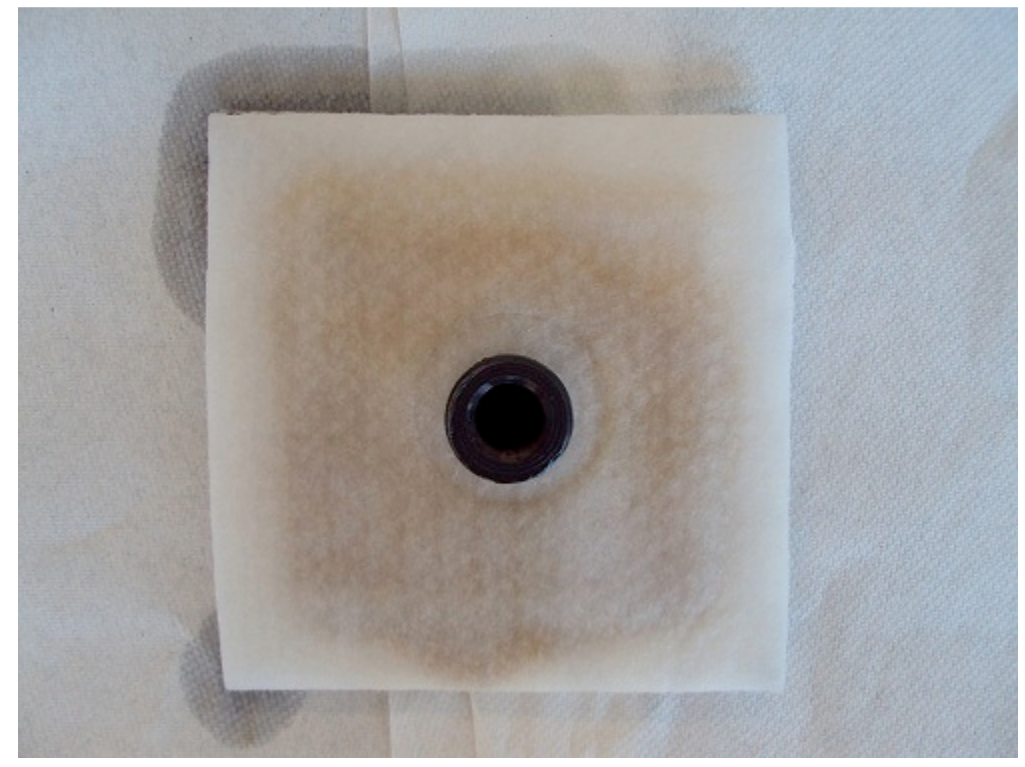

Figure 4.5: External appearance of square filter tested in experiment B-3 after 12 uses. Scale: the large diameter bulkhead fitting is $2.22 \mathrm{~cm}$ in diameter.

In experiment B-3, the water entered the internal chamber of the filter and flowed perpendicular to the filter cloth. The high velocity of the water in the perpendicular flow was believed to possibly force microspheres through the filter cloth. It was also 
hypothesized that a rectangular filter would be more beneficial as the water could flow tangentially to the material, allowing the water to diffuse through the filter cloth as opposed to being forced through it. Therefore, a rectangular filter was used in all subsequent experiments. From these experiments, it was determined that an external filter with an internal chamber to catch floc would be the best design to further pursue.

\subsubsection{Configuration Experiments C-1 and C-2: Hardware}

The filters constructed for experiments A-1 to B-3 were all constructed with large diameter bulkhead fittings. The flow of water from the waterbag, through the filter was too fast and the large diameter bulkhead fittings had a larger than ideal diameter for the development of a low-profile filter, so it was hypothesized that using a lower-profile bulkhead fitting would reduce the hydraulic loading onto the filter cloth as well as allow the filter to have a thinner profile. Therefore, small diameter bulkhead fittings and flat washers were obtained (Section 3.1). The large diameter bulkhead fittings were used in the filter constructed for experiment C-1. The small diameter bulkhead fittings and low profile washers were used in the filters constructed for experiment C-2.

No difference was observed in hydraulic loading onto the filter cloth between the two bulkhead fittings because flowrates through each bulkhead fitting were similar when the flow control valves were fully open. Therefore, it was determined that no change in bulkhead fittings was required, and large diameter bulkheads were used in all subsequent experiments. 


\subsubsection{Configuration Experiments D-1 and D-2: Dye Studies}

Dye studies were conducted with both the square filters used in experiment B-3 and the rectangular filters used in experiments C-1 and C-2. Dye studies were performed on both clean and dirty, square and rectangular filters to determine how water flowed through the filter cloth during the usable lifetime of the filter.

First, a dye study of a clean, square filter was performed to determine how the water initially flowed through the clean material (Figure 4.6). Next, a dye study of a dirty, square filter was performed to determine how the flow of water through the material changed once the filter had been used (Figure 4.7).

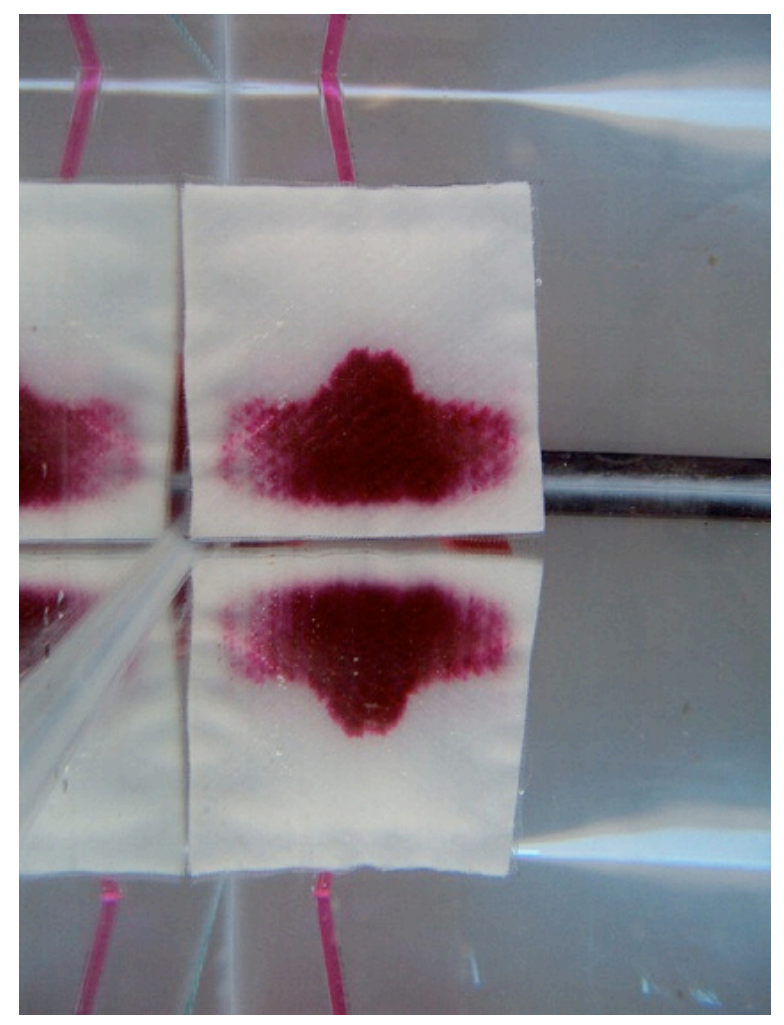

Figure 4.6: Side view of rhodamine dye and water mixture flowing through a clean, square filter in experiment D-1. Note, the dye was concentrated during this trial fof experiment D-1 and could have affected the results. Scale: the square filter measures $7.6 \mathrm{~cm}$ by $7.6 \mathrm{~cm}$. 


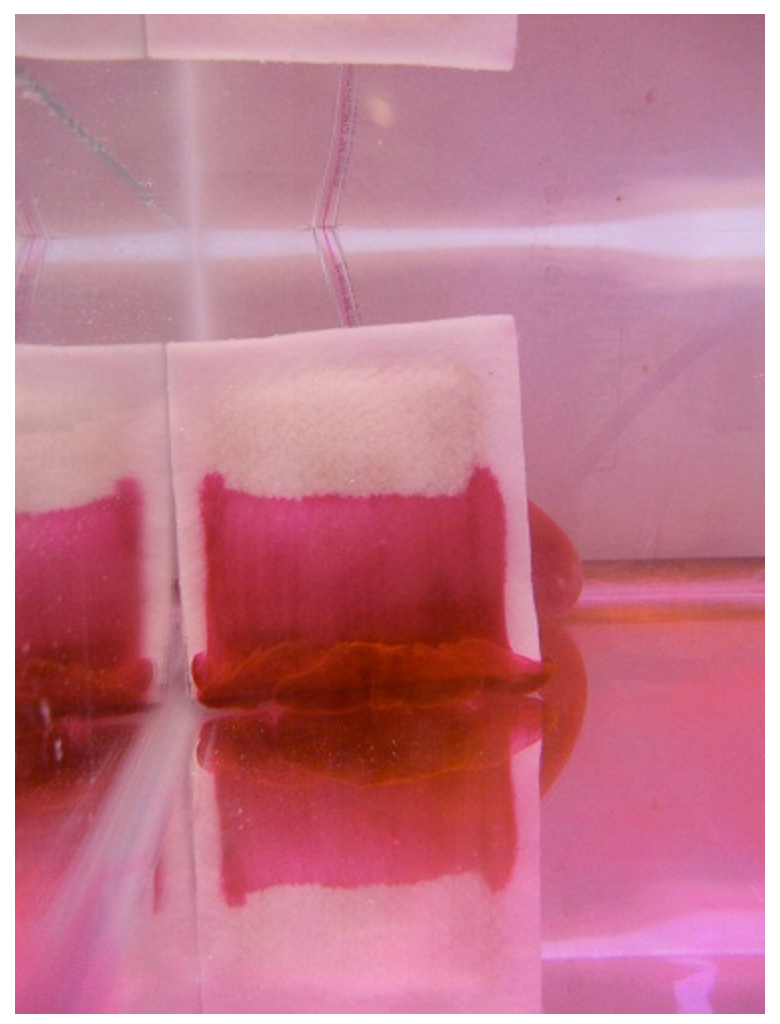

Figure 4.7: Side view of rhodamine dye and water mixture flowing through a dirty, square filter in experiment D-1. Note, the dye was concentrated during this trial fof experiment D-1 and could have affected the results. Scale: the square filter measures $7.6 \mathrm{~cm}$ by $7.6 \mathrm{~cm}$.

By comparison of Figure 4.6 and Figure 4.7, it was determined that in a clean filter, water being filtered only flowed through the filter cloth that was below the point of entry into the internal chamber of the filter. Figure 4.7 also showed that after use, the pores began to clog, and the water being filtered flowed through slightly more of the filter area, as can be seen by the rhodamine dye and water mixture forming a straight line halfway across the filter face, as compared to the curved line around the bulkhead fitting in Figure 4.6. These observations reinforced the hypothesis that the filter should be rectangular in shape to allow for a larger usable filter area as the rectangular filter was the same height as the square filter, but had a longer length. The observations also led to a 
hypothesis that the inlet into the internal chamber of the filter needed to be as high as possible to allow for use of the largest amount of filter area.

The dye study of the square filter also showed the jetting-action of water being forced through the filter cloth upon entry into the internal chamber (Figure 4.8).

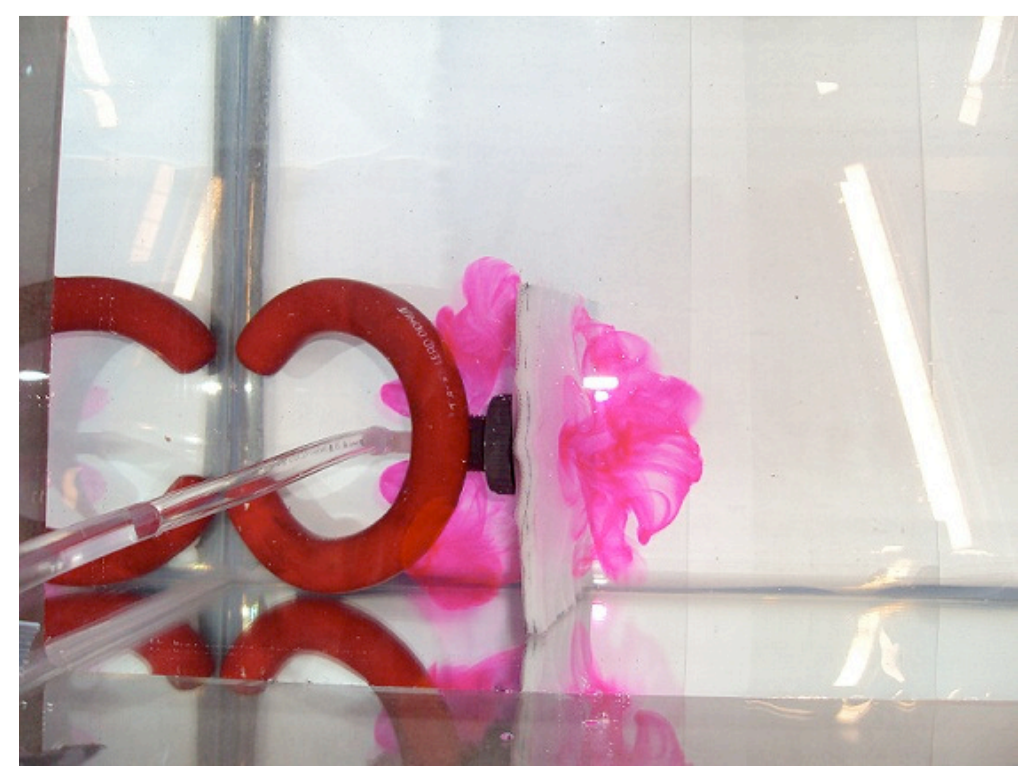

Figure 4.8: Plan view of plume of rhodamine dye and water mixture jetting out of the internal chamber of a square filter in experiment D-1. Scale: the large diameter bulkhead on the left side of the filter measures $3.65 \mathrm{~cm}$ in diamter.

The jetting of water through the material of the square filters could potentially force microspheres through the filter cloth as well. This was not ideal as the filter would not be performing microsphere removal as microspheres could be forced through the filter cloth. Figure 4.8 reinforced the hypothesis that parallel flow to filter cloth rather than perpendicular flow is preferred as the water would be able to diffuse slowly through the filter cloth rather than being forced through as a jet.

The small diameter bulkhead fitting used on the clean filter shown in Figure 4.9 was placed as close the top of the filter as physically possible during filter construction. 


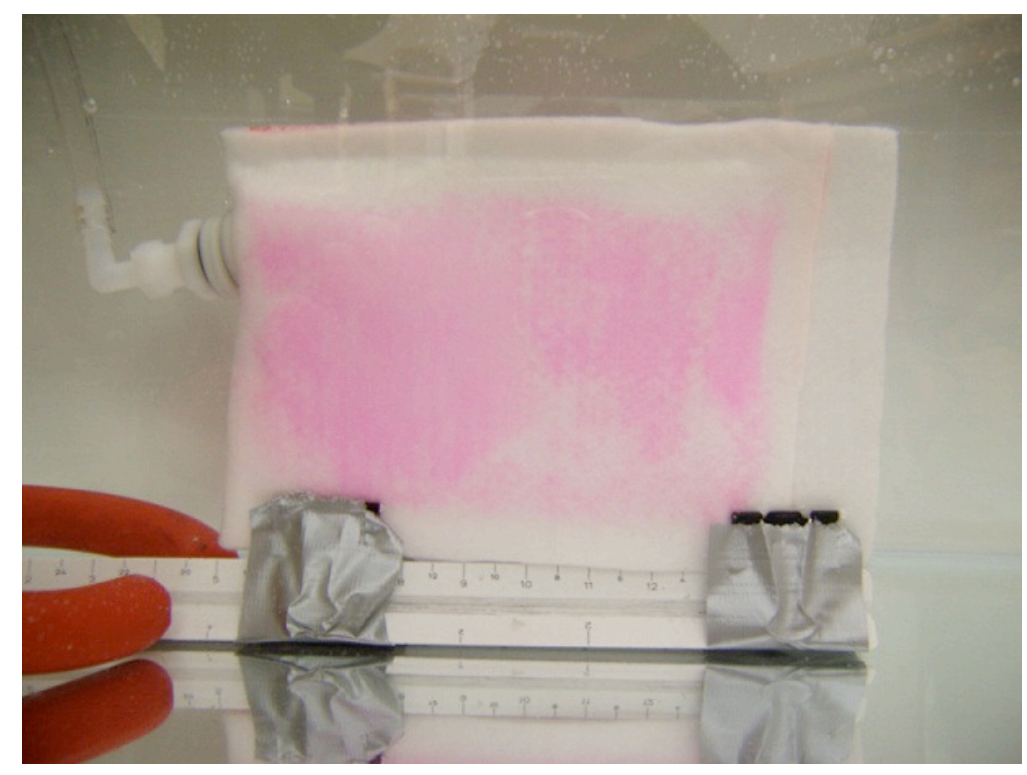

Figure 4.9: Side view of a clean, rectangular filter with a high bulkhead fitting used in experiment D-2. Scale: the rectangular filter measures $10.2 \mathrm{~cm}$ by $15.2 \mathrm{~cm}$.

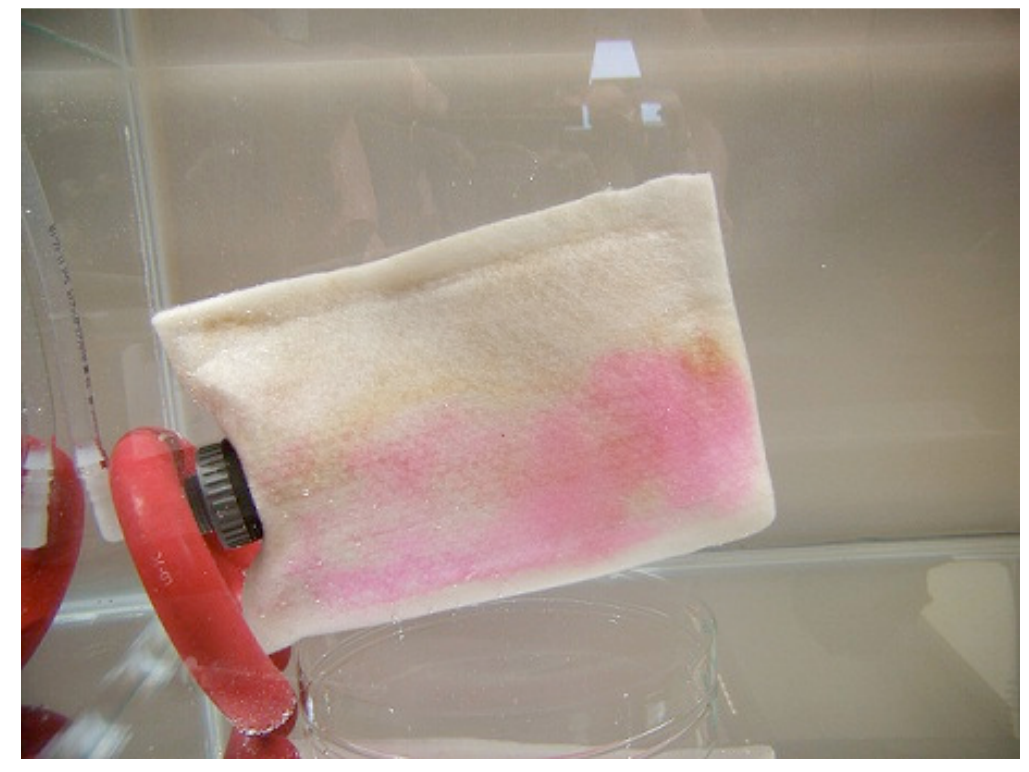

Figure 4.10: Side view of a dirty, rectangular filter with a middle bulkhead fitting used in experiment D-2. Scale: the large diameter bulkhead fitting on the left side of the filter meausres $3.65 \mathrm{~cm}$ in diameter.

Comparison of Figure 4.9 and Figure 4.10 indicates that increasing the height of the

inlet bulkhead fitting on the filter increases the filter area used by the water. Experiment

D-2 also suggested that parallel flow along the filter allowed the water to diffuse through 
the material (Figure 4.11) as opposed to the jetting observed in perpendicular flow

(Figure 4.8). Therefore, it was determined that a rectangular filter with a high-mounted bulkhead fitting would be used in all subsequent experiments.

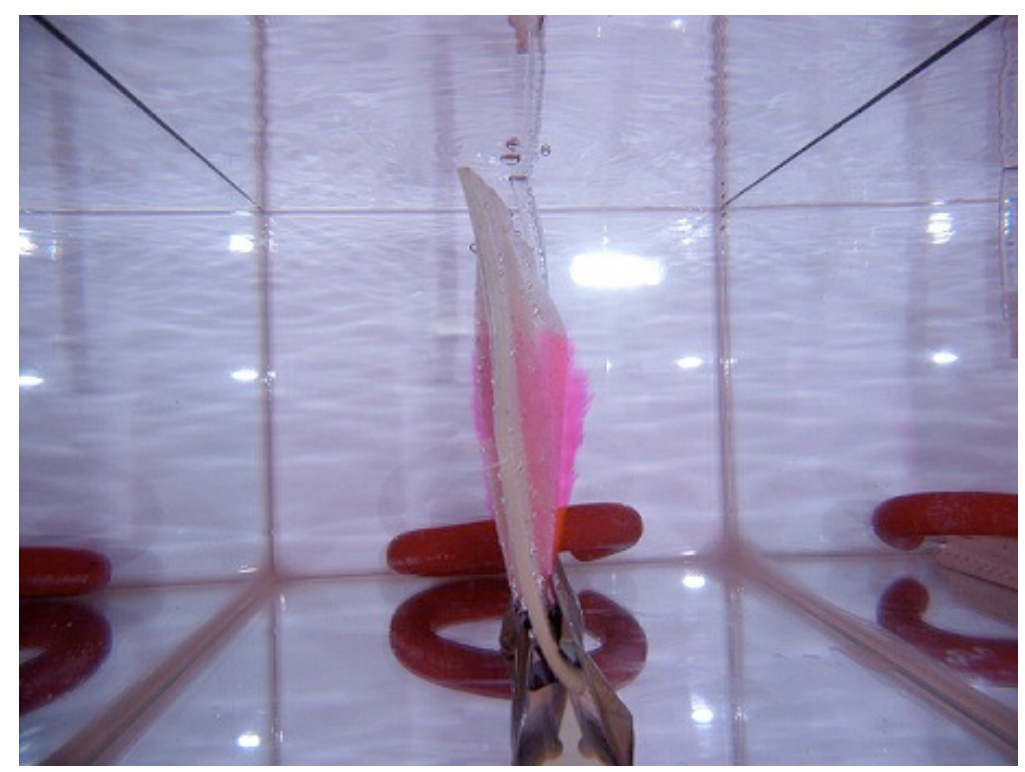

Figure 4.11: Side view of thin plume of rhodamine dye and water mixture observed along clean, rectangular filter tested in experiment D-2. Scale: the clear tubing in the upper half of the picture measures $0.75 \mathrm{~cm}$ in diameter.

\subsubsection{Microsphere Removal Experiments E-1 and E-2: Nominal Material Filters}

Initially a 1-ply nominal filter was tested in experiment E-1 for microsphere removal capabilities. After analysis under the fluorescent microscope, 440 microspheres were observed $\left(4.4 \times 10^{4}\right.$ spheres/L). It was hypothesized that decreasing the flowrate by half and adding a second layer of the nominal material would decrease the number of microspheres observed under the fluorescent microscope by four.

A 2-ply nominal filter was tested in experiment E-2. Note, a stopcock valve was used to throttle the flowrate of treated water entering the inner chamber of the filter from the waterbag to roughly $500 \mathrm{~mL} / \mathrm{min}$. Analysis of the post-filter effluent showed 123 
microspheres in the effluent $\left(1.2 \times 10^{4}\right.$ spheres/L), thereby indicating the hypothesis was correct. At the conclusion of experiments E-1 and E-2, it was determined that a 2-ply filter would be used in all subsequent experiments and the flowrate would be continually reduced until removal requirements were achieved.

\subsubsection{Microsphere Removal Experiments F-1 to F-3: Absolute Material Filters}

A 1-ply absolute filter was assembled and tested for usability and microsphere removal capabilities in experiment F-1. This filter required the waterbag to be raised 65 in off the ground and the filter to be placed on the ground (instead of attached to the waterbag) in order to produce flow. The flowrate decreased drastically after four liters of water were filtered and became clogged. Enumeration of samples determined that 162 spheres were present in the $10 \mathrm{~mL}$ filtered effluent sample $\left(1.6 \times 10^{4}\right.$ spheres/L). From these results, it was determined that the absolute material would yield more positive results when used as a polishing filter after the water had passed through the nominal filter, which would act as a roughing filter.

A bench-scale 2-ply nominal-absolute filter was tested in experiment F-2. Analysis of the filtrate showed numerous spheres in the sample. It was hypothesized that source water leaked around the edges of the vacuum filter funnel assembly, as the edges were not sealed; this could have led to the observed microspheres in the sample. It was determined that a full-scale 2-ply nominal-absolute filter would be built in order to determine removal capabilities.

A full-scale 2-ply nominal-absolute filter was tested in experiment F-3. Flow was produced from this filter when the filter was attached to the waterbag and the waterbag 
was raised 65 in off the ground. This filter performed quite well and only 54 spheres were observed in the effluent sample $\left(5.4 \times 10^{3}\right.$ spheres/L). Therefore, the 2-ply nominalabsolute filter will be used in subsequent mock challenge water experiments.

\subsubsection{Mixing Time Experiments G-1 to G-3: Mixing Time with 2-ply Nominal Filters}

Experiments G-1 to G-3 were performed to determine if a longer mixing time would positively influence turbidity and microsphere removal. It was hypothesized that a longer mixing time would allow more flocs to form, thus removing more turbidity and microspheres from the treated effluent. Therefore, $5 \mathrm{~min}, 10 \mathrm{~min}$, and $15 \mathrm{~min}$ mixing times were tested.

Unfiltered samples were collected for these experiments as turbidity and presence of flos were the main variables in question. Samples were taken at $0 \mathrm{~L}$, when no water had previously been draw out of the waterbag, and after $4 \mathrm{~L}$ had been drawn out of the waterbag. Samples were collected in $100 \mathrm{~mL}$ beakers. After visual inspection, samples taken from the 5 min mix waterbag tested in experiment G-1 had the least amount of floc present (Figure 4.12 and Figure 4.13). 


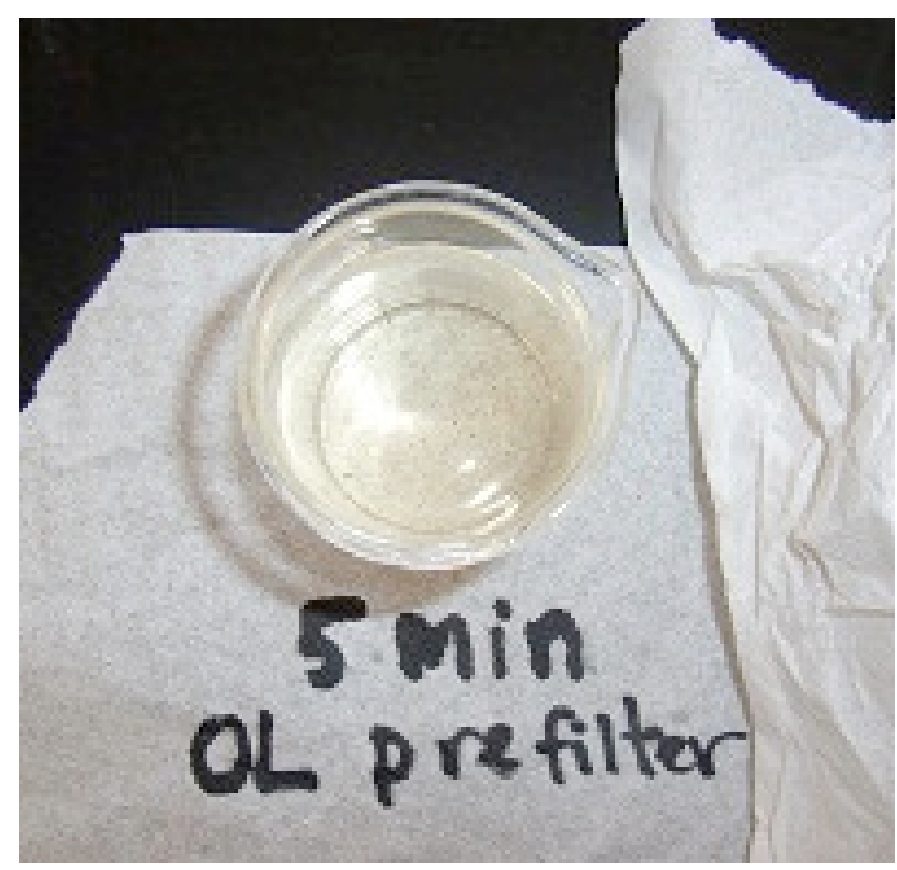

Figure 4.12: Experiment G-1 (5 min mix waterbag). The photo shows about $80 \mathrm{~mL}$ of unfiltered sample collected in a $100 \mathrm{~mL}$ beaker before any water had been drained from the bag.

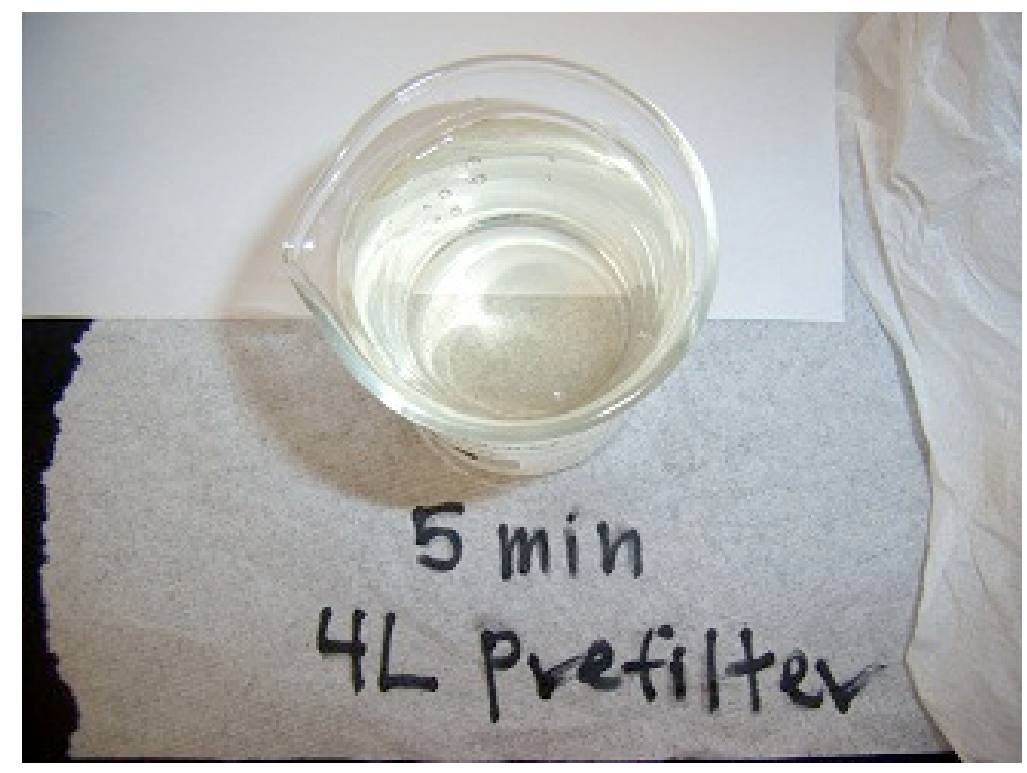

Figure 4.13: Experiment G-1 (5 min mix waterbag). The photo shows about $80 \mathrm{~mL}$ of unfiltered sample in a $100 \mathrm{~mL}$ beaker after $4 \mathrm{~L}$ had been drained from the bag.

After visual inspection, samples taken from the 10-min mix waterbag tested in experiment G-2 had the greatest amount of floc present as well as the highest turbidity 
(Figure 4.14 and Figure 4.15). The effluent also had a discernible yellow hue, as can be seen in Figure 4.14 and Figure 4.15.

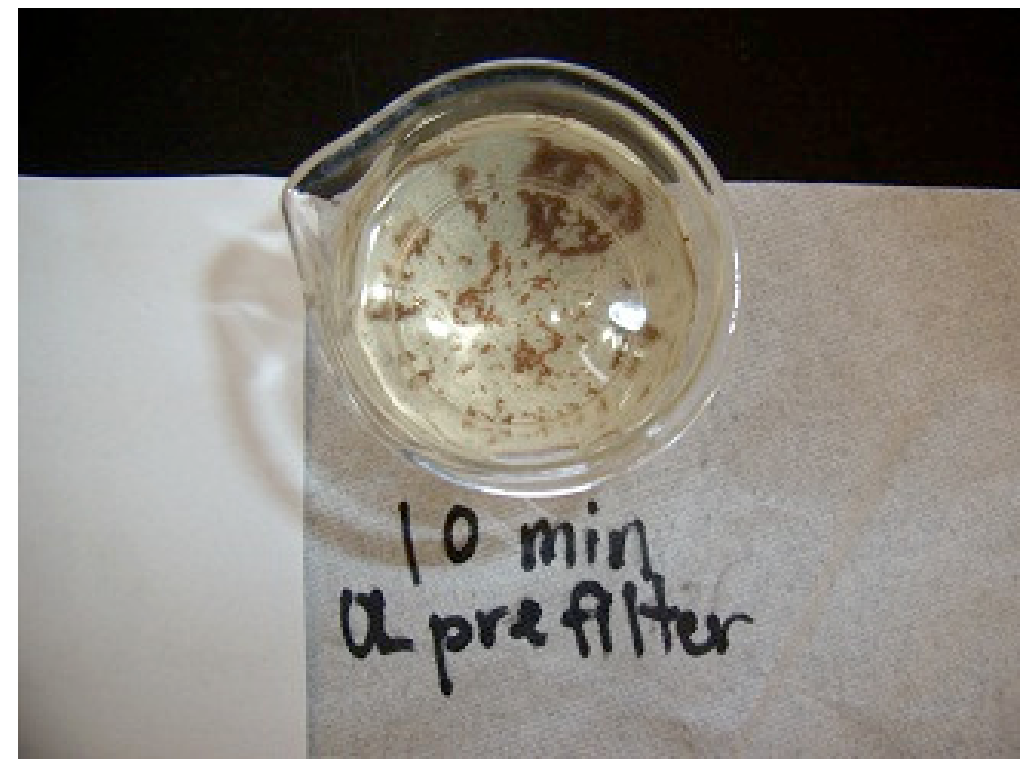

Figure 4.14: Experiment G-2 (10 min mix waterbag). The photo shows about $80 \mathrm{~mL}$ of unfiltered sample collected in a $100 \mathrm{~mL}$ beaker before any water had been drained from the bag.

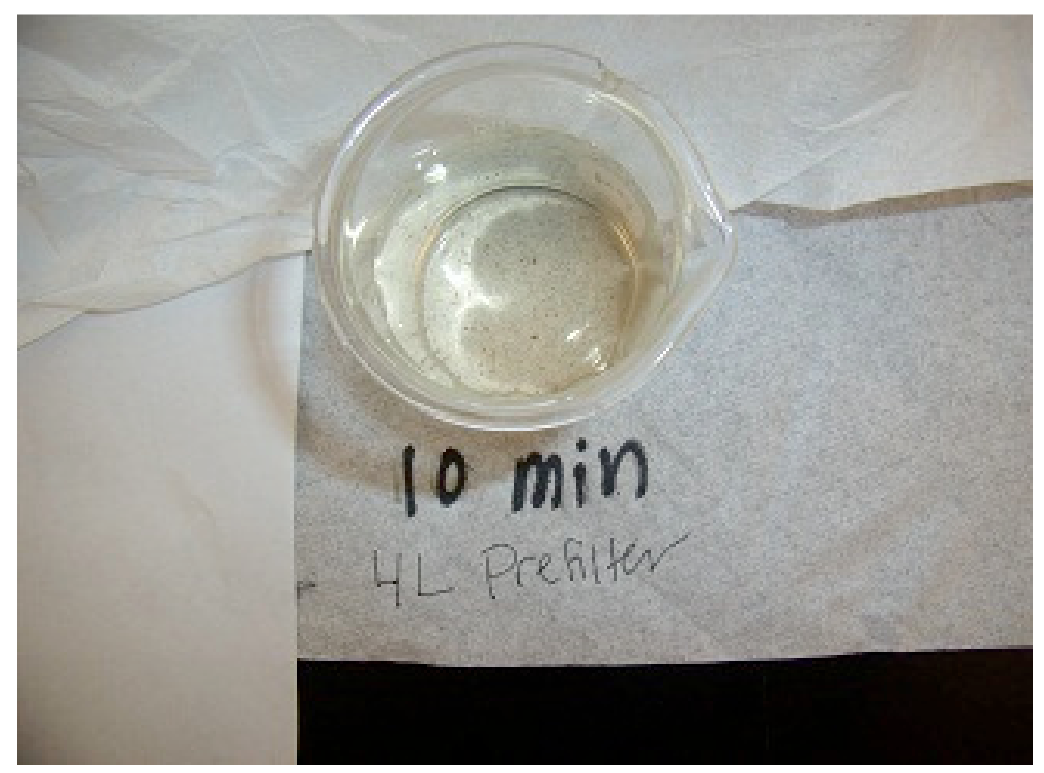

Figure 4.15: Experiment G-2 (10 min mix waterbag). The photo shows about 80 $\mathrm{mL}$ of unfiltered sample in a $100 \mathrm{~mL}$ beaker after $4 \mathrm{~L}$ had been drained from the bag. 
After visual inspection, samples taken from the 15 min mix waterbag tested in experiment G-3 had less floc present than the $10 \mathrm{~min}$ mix, but more floc than the $5 \mathrm{~min}$ mix (Figure 4.16 and Figure 4.17). The turbidity of samples taken from the $15 \mathrm{~min}$ mix waterbag was greater than that measured from the 5 min mix waterbag and less than that measured from the $10 \mathrm{~min}$ mix waterbag.

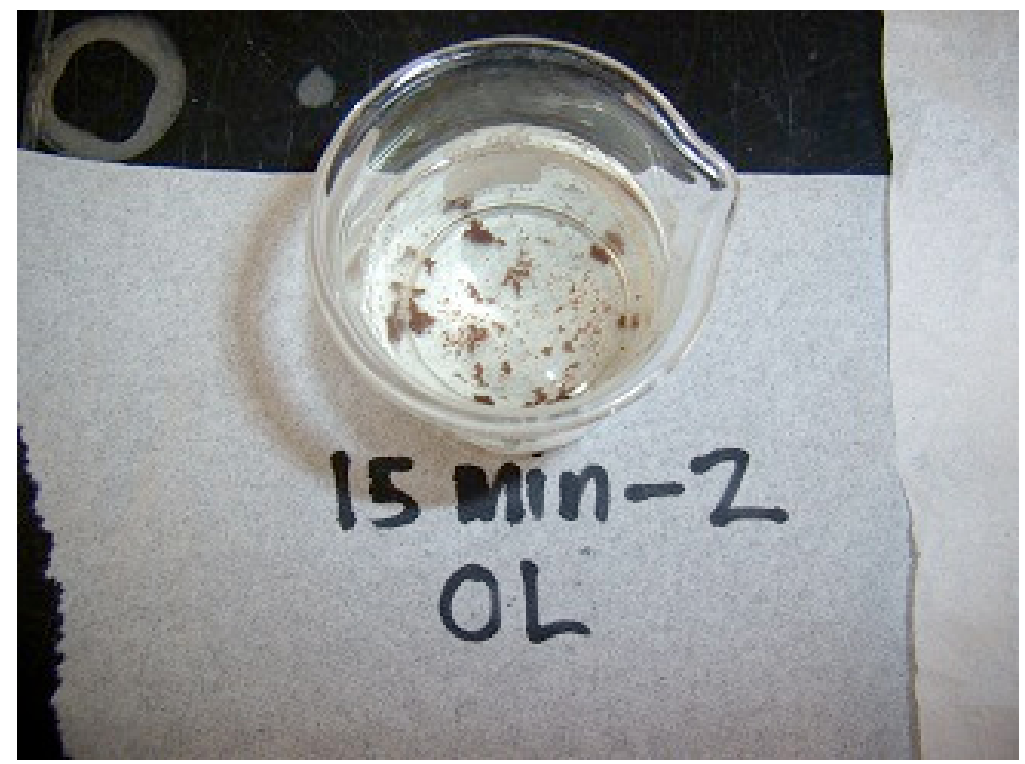

Figure 4.16: Experiment G-3 (15 min mix waterbag). The photo shows about $80 \mathrm{~mL}$ of unfiltered sample collected in a $100 \mathrm{~mL}$ beaker before any water had been drained from the bag. 


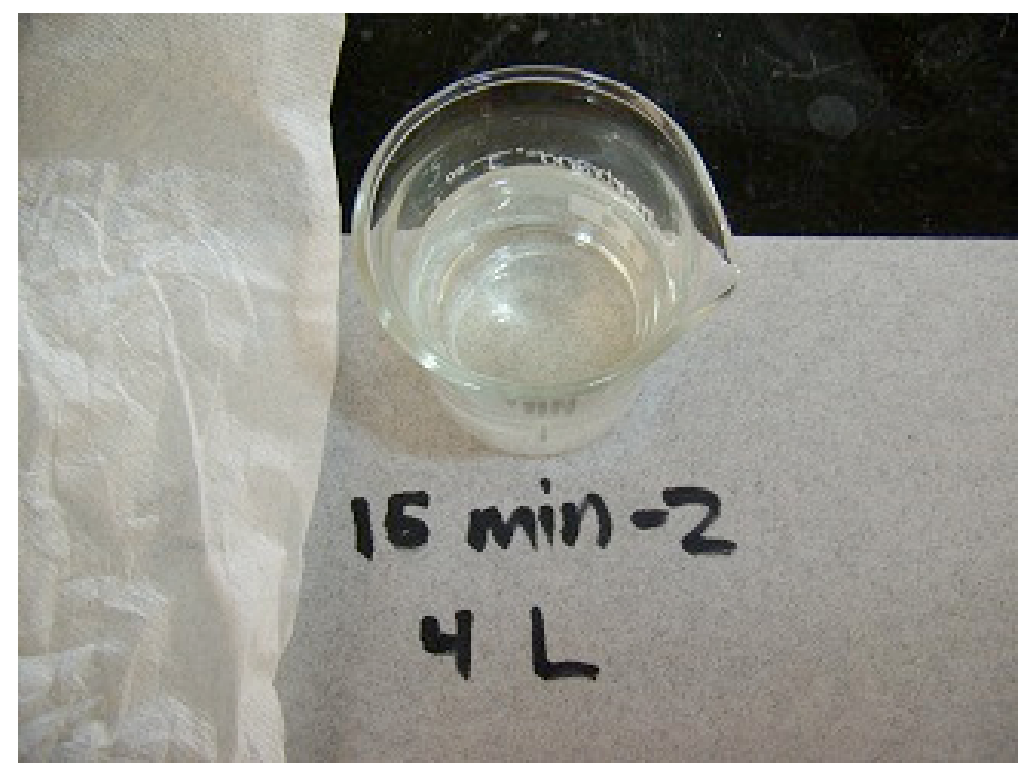

Figure 4.17: Experiment G-3 (15 min mix waterbag). The photo shows about $80 \mathrm{~mL}$ of unfiltered sample collected in a $100 \mathrm{~mL}$ beaker after $4 \mathrm{~L}$ had been drained from the bag.

From these experiments, based on the increased amount of floc present in the unfiltered 0-L samples of both the 10 min and 15 min mix times, it was determined that the extended mixing time resulted in too much shear force introduced into the waterbag. This increased shear broke the original large flocs formed during the $5 \mathrm{~min}$ mix into smaller pieces that took much longer to settle by gravity. By comparison of the 0-L samples with the 4-L samples, it was also determined that while the flocs from the $10 \mathrm{~min}$ and 15-min mix periods are smaller than those from the 5-min mix period, they are still large enough to be affected by gravity. The smaller floc size was indicated by the decreased amount of floc present in the 4-L samples from both the 10- and 15-min mix periods. As time elapsed during the experiments, smaller flocs were able to settle out. From the results of these experiments, it was determined that a 5-min mix, as previously used, would continue to be used for all subsequent experiments. 


\subsection{U.S. EPA Challenge Water Experiments}

The final experiments tested various filters' ability to meet the U.S. EPA Guide Standard and Protocol for Testing Microbiological Water Purifiers. The three filters tested against U.S. EPA Challenge Water \#2 were 1-ply nominal, 2-ply nominal, and 2-ply nominalabsolute. The three final filters were tested to determine treatment capability and appropriate flowrate for the filter to be used during the final experiment at BioVir Laboratories. Upon completion of these experiments, the 2-ply nominal-absolute filter was used for the official U.S. EPA Challenge Test was conducted at BioVir Laboratories.

\subsubsection{Experiments H-1 to H-3: Mock Challenge Water}

Three filter designs were tested in the Cal Poly lab against mock U.S. EPA Challenge Water\#2: 1-ply nominal filter (experiment H-1), 2-ply nominal filter (experiment H-2), and 2-ply nominal-absolute (liquid fusion) filter (experiment H-3). Turbidity, flowrate, head, chlorine residual, temperature, bacteria removal, as well as microsphere removal data were collected.

\subsubsection{Experiment H-1: 1-ply Nominal Filter}

In experiment $\mathrm{H}-1$, the 1-ply nominal filter was tested at a $500 \mathrm{~mL} / \mathrm{min}$ flowrate.

Microsphere samples were collected and analyzed from the untreated test water and after 4-L of treated effluent had been filtered. Table 4.1 details the initial; treated, unfiltered; and treated, filtered effluent microsphere concentrations as well as log removals during each step in the treatment process. The overall microsphere removal for the 1-ply nominal filter was 0.60 logs. Due to the low sphere removal results, it was determined that the 1-ply nominal filter could not meet the U.S. EPA Challenge Water \#2 removal 
requirements and would not be used for the official U.S. EPA Challenge test at BioVir Laboratories.

Table 4.1: Microsphere concentration and log removal at each step in the treatment process with 1-ply nominal filter during the Mock Challenge Water \#2 treatment attempt in experiment $\mathrm{H}-1$.

\begin{tabular}{lcc}
\hline \multicolumn{1}{c}{$\begin{array}{c}\text { Step in the Treatment } \\
\text { Process }\end{array}$} & $\begin{array}{c}\text { Concentration } \\
\text { (spheres/L) }\end{array}$ & $\begin{array}{c}\text { Log Removal of } \\
\text { Each Step }\end{array}$ \\
\hline Source water & $1.42 \times 10^{6}$ & -- \\
Treated, unfiltered effluent & $5.81 \times 10^{5}$ & 0.39 \\
Treated, filtered effluent & $3.59 \times 10^{5}$ & 0.21 \\
Overall removal & -- & 0.60 \\
\hline
\end{tabular}

\subsubsection{Experiment H-2: 2-ply Nominal Filter}

In experiment $\mathrm{H}-2$, the 2-ply nominal filter was tested at a flowrate of $65 \mathrm{~mL} / \mathrm{min}$. Grab samples were collected of untreated test water and after $4 \mathrm{~L}$ of treated effluent had been filtered. The source water temperature was $14^{\circ} \mathrm{C}$ and the initial turbidity was $47.0 \mathrm{NTU}$. On average, treated, unfiltered turbidity was 3.65 NTU and treated, filtered turbidity was 3.35 NTU. Both of these measured turbidity values meet the $<5$ NTU requirement, as required by The Sphere Project (The Sphere Project, 2004). A chlorine residual of 0.05 $\mathrm{mg} / \mathrm{L}$ was measured in the treated, filtered effluent sample. The measured microsphere removal at each step in the treatment process can be seen Table 4.2. The microsphere removal increased with the addition of a second layer of nominal filter cloth and decreasing the flowrate by approximately 7.5 times, but was still below the U.S. EPA Challenge Water removal requirement of 3-log removal. Table 4.3 outlines the total coliform and E. coli removals at each step in the treatment process. The bacteria removal of 5.01 and $5.03 \log$ (coliform and E. coli removals, respectively) was not sufficient to meet the U.S. EPA Challenge Water requirement of 6-log removal. 
Table 4.2: Microsphere concentration and log removal at each step in the treatment process with 2-ply nominal filter during the Mock Challenge Water \#2 treatment attempt in experiment $\mathbf{H}-2$.

\begin{tabular}{lcc}
\hline \multicolumn{1}{c}{$\begin{array}{c}\text { Step in the Treatment } \\
\text { Process }\end{array}$} & $\begin{array}{c}\text { Concentration } \\
\text { (spheres/L) }\end{array}$ & $\begin{array}{c}\text { Log Removal of } \\
\text { Each Step }\end{array}$ \\
\hline Source water & $9.18 \times 10^{5}$ & -- \\
Treated, unfiltered effluent & $3.63 \times 10^{4}$ & 1.40 \\
Treated, filtered effluent & $1.81 \times 10^{4}$ & 0.30 \\
Overall removal & -- & 1.70 \\
\hline
\end{tabular}

Table 4.3: Coliform and $E$. coli concentration and log removal at each step in the treatment process with 2-ply nominal filter during the Mock Challenge Water \#2 treatment attempt in experiment $\mathrm{H}-2$.

\begin{tabular}{lcc}
\hline \multicolumn{1}{c}{ Step in the Treatment Process } & $\begin{array}{c}\text { Concentration } \\
\text { (MPN/100-mL) }\end{array}$ & $\begin{array}{c}\text { Log Removal of } \\
\text { Each Step }\end{array}$ \\
\hline Source water, coliform & \\
Treated, unfiltered effluent, coliform & $2.71 \times 10^{6}$ & -- \\
Treated, filtered effluent, coliform & -- & -- \\
Overall coliform removal & 26.5 & -- \\
\hline Source water, E. coli & -- & 5.01 \\
Treated, unfiltered effluent, E. coli & $1.72 \times 10^{6}$ & -- \\
Treated, filtered effluent, E. coli & -- & -- \\
Overall E. coli removal & 16.1 & -- \\
\hline
\end{tabular}

${ }^{1}$ A source water sample was not collected for experiment $\mathrm{H}-2$. Therefore, the average of all concentrations of source water for experiment $\mathrm{H}-3$ was taken to allow for enumeration.

Due to the poor microsphere and bacteria removal results, it was determined that the 2ply nominal filter could not meet the U.S. EPA Challenge Water \#2 removal requirements and would not be used for the official U.S. EPA Challenge test at BioVir Laboratories.

\subsubsection{Experiment H-3: 2-ply Nominal-Absolute Filter}

The 2-ply nominal-absolute filter was tested in experiment H-3 at two flowrates: 50 $\mathrm{mL} / \mathrm{min}$ and $20 \mathrm{~mL} / \mathrm{min}$. Grab samples were collected of untreated test water and after 4 
$\mathrm{L}$ of treated effluent had been filtered. For the $50 \mathrm{~mL} / \mathrm{min}$ tests, the source water temperature was $14^{\circ} \mathrm{C}$ and $11^{\circ} \mathrm{C}$ in Bag 1 and 2, respectively. Turbidity of source water, pre-filter samples, and post-filter samples are all shown in Figure 4.18. Both pre-filter and post-filter samples meet the $<5$ NTU requirement, as required by The Sphere Project (The Sphere Project, 2004).

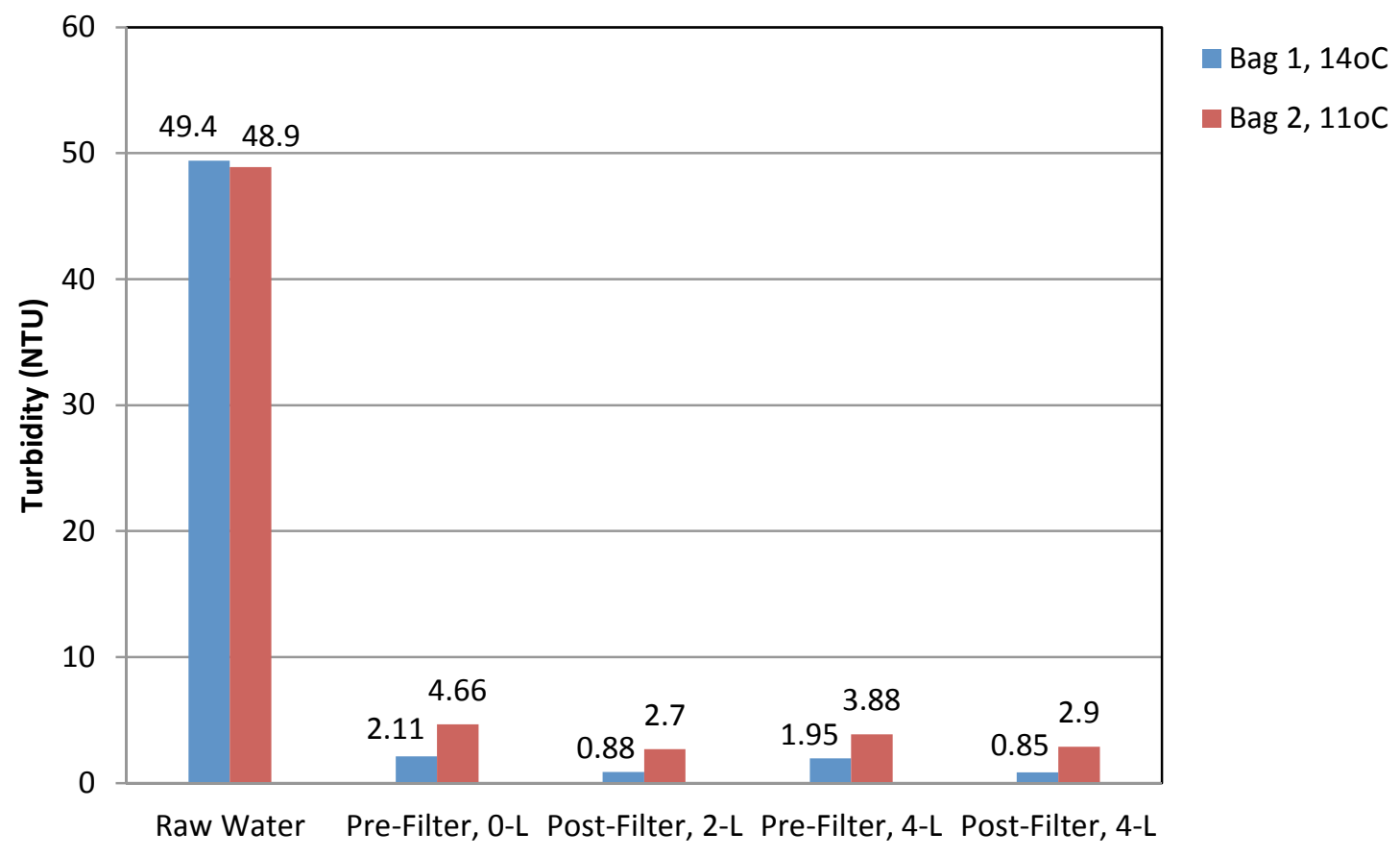

Figure 4.18: Turbidity of samples collected at various points from waterbags with a $50 \mathrm{~mL} / \mathrm{min}$ flowrate throughout experiment H-3.

Chlorine residuals of 0.04 and $0.03 \mathrm{mg} / \mathrm{L}$ were measured in the treated, filtered effluent samples from Bag 1 and 2, respectively. The measured chlorine residuals did not meet the required $0.2-0.5 \mathrm{mg} / \mathrm{L}$ chlorine residual mandated by The Sphere Project and the WHO. Microsphere removal increased with the use of the absolute material (Table 4.4) up to an overall removal of 2.18 logs, but was still below the U.S. EPA Challenge Water removal requirements of 3-log removal. Table 4.5 outlines the total coliform and E. coli 
removals at each step in the treatment process. The bacteria log removal was not sufficient to meet the U.S. EPA Challenge Water requirement of 6-log removal. The results of the total coliform and $E$. coli test were not exact because not enough dilutions were performed to find the exact concentration and log removals.

Table 4.4: Microsphere concentration and log removal at each step in the treatment process with 2-ply nominal-absolute filter during the Mock Challenge Water \#2 treatment attempt in experiment $\mathrm{H}-3$ at $50 \mathrm{~mL} / \mathrm{min}$ flowrate.

\begin{tabular}{|c|c|c|}
\hline $\begin{array}{c}\text { Step in the Treatment } \\
\text { Process } \\
\end{array}$ & $\begin{array}{c}\text { Concentration } \\
\text { (spheres/L) }\end{array}$ & $\begin{array}{l}\text { Log Removal of } \\
\text { Each Step } \\
\end{array}$ \\
\hline Source water ${ }^{1}$ & $1.10 \times 10^{7}$ & -- \\
\hline Treated, unfiltered effluent ${ }^{1}$ & $9.62 \times 10^{4}$ & 1.75 \\
\hline Treated, filtered effluent ${ }^{1}$ & $2.90 \times 10^{4}$ & 0.43 \\
\hline Overall removal $^{1}$ & -- & 2.18 \\
\hline
\end{tabular}

Table 4.5: Coliform and E. coli concentration and log removal at each step in the treatment process with 2-ply nominal-absolute filter during the Mock Challenge Water \#2 treatment attempt in experiment $\mathrm{H}-3$ at $50 \mathrm{~mL} / \mathrm{min}$ flowrate.

\begin{tabular}{|c|c|c|}
\hline Step in the Treatment Process & $\begin{array}{l}\text { Concentration } \\
\text { (MPN/100 mL) }\end{array}$ & $\begin{array}{l}\text { Log Removal of } \\
\text { Each Step }\end{array}$ \\
\hline Source water, coliform $^{1}$ & $1.61 \times 10^{6}$ & -- \\
\hline Treated, unfiltered effluent, coliform ${ }^{1}$ & $>2419.6$ & $<2.86$ \\
\hline Treated, filtered effluent, coliform ${ }^{1}$ & $>2419.6$ & -- \\
\hline Overall coliform removal ${ }^{1}$ & -- & $<2.86$ \\
\hline Source water, $E$. coli $^{1}$ & $1.10 \times 10^{6}$ & -- \\
\hline Treated, unfiltered effluent, $E$. coli ${ }^{1}$ & $>2419.6$ & $<2.66$ \\
\hline Treated, filtered effluent, $E . c c_{i}{ }^{1}$ & 1011.2 & $>0.38$ \\
\hline Overall E. coli removal ${ }^{1}$ & -- & $>3.04$ \\
\hline
\end{tabular}

Due to the low microsphere and bacteria log removal results, it was determined that the 2-ply nominal-absolute filter could not meet the U.S. EPA Challenge Water \#2 removal requirements even when the flowrate was only $50 \mathrm{~mL} / \mathrm{min}$. Therefore, this flowrate would not be used for the official U.S. EPA Challenge test at BioVir Laboratories. 
As a $50 \mathrm{~mL} / \mathrm{min}$ flowrate did not provide adequate removal, the flowrate was reduced to $20 \mathrm{~mL} / \mathrm{min}$. For the $20 \mathrm{~mL} / \mathrm{min}$ tests, the source water temperature was $9^{\circ} \mathrm{C}$ and $9.5^{\circ} \mathrm{C}$ in Bag 1 and 2, respectively. A port screen was also taped over the exit port on the waterbag leading to the filter pouch. The port screen (plastic material with approximately $0.5 \mathrm{~mm}$ pore size) prevented unsettled flocs from entering the filter. Turbidity of source water, pre-filter samples, and post-filter samples are all shown in Figure 4.19. Both prefilter and post-filter samples meet the $<5$ NTU requirement, as required by The Sphere Project (The Sphere Project, 2004).

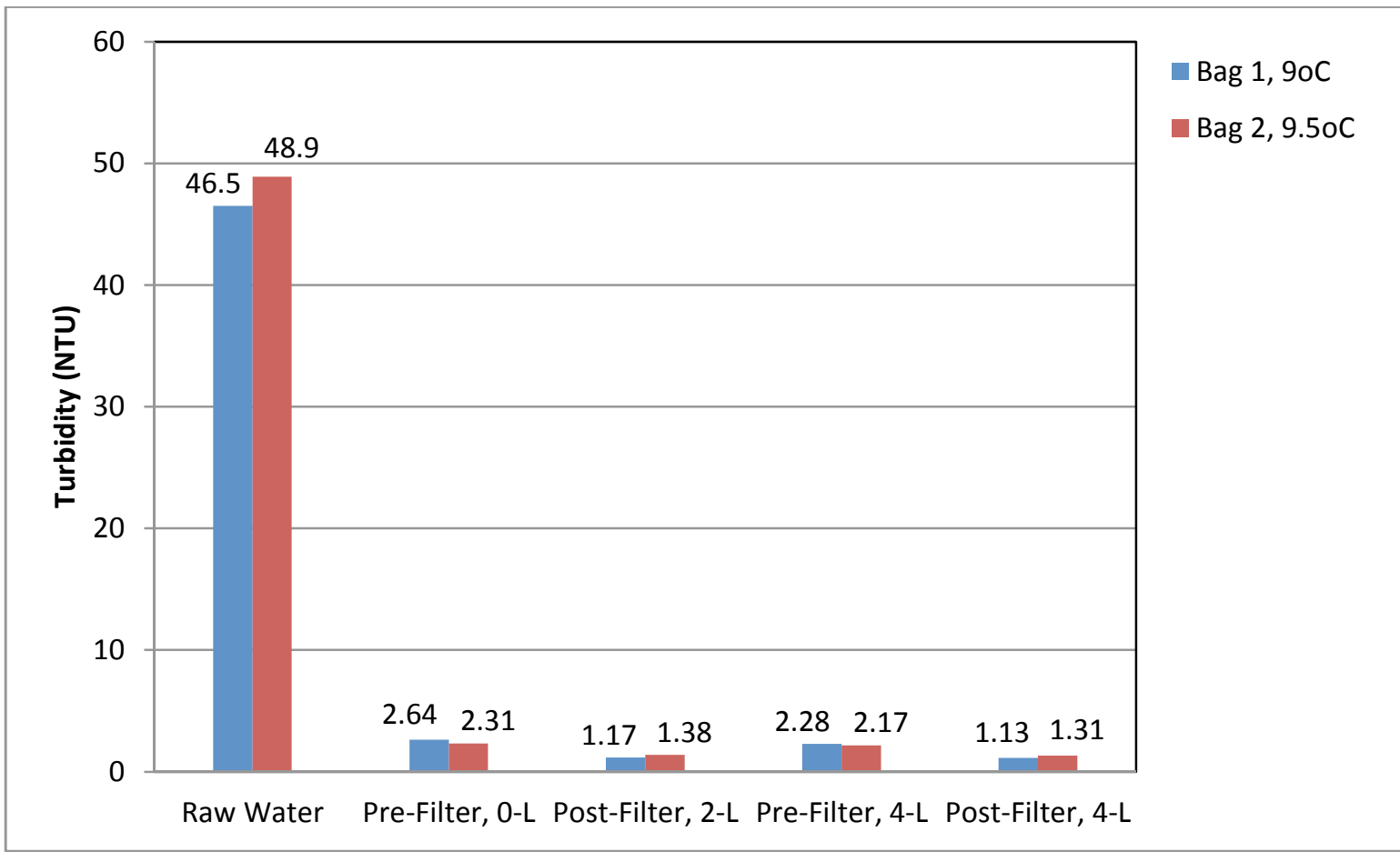

Figure 4.19: Turbidity of samples collected at various points from waterbags with a $20 \mathrm{~mL} / \mathrm{min}$ flowrate and a port screen throughout experiment H-3.

Chlorine residuals of 0.04 and $0.06 \mathrm{mg} / \mathrm{L}$ were measured in the treated, filtered effluent samples from Bag 1 and 2, respectively. The measured microsphere removal at each step in the treatment process can be seen in Table 4.6. The microsphere removal increased 
when the flowrate was decreased by approximately 2.5 times to $3.92 \log$ and now exceeded the U.S. EPA Challenge Water removal requirement of 3-log removal. Table 4.7 outlines the total coliform and E. coli removals at each step in the treatment process. The bacteria removal was 6.74 and $6.50 \log$ (coliform and E. coli removals, respectively), which exceeded the U.S. EPA Challenge Water requirement of 6-log removal.

Table 4.6: Microsphere concentration and log removal at each step in the treatment process with 2-ply nominal-absolute filter and a port screen during the Mock Challenge Water \#2 treatment attempt in experiment $\mathrm{H}-3$ at $20 \mathrm{~mL} / \mathrm{min}$ flowrate.

\begin{tabular}{|c|c|c|}
\hline $\begin{array}{c}\text { Step in the Treatment } \\
\text { Process }\end{array}$ & $\begin{array}{c}\text { Concentration } \\
\text { (spheres/L) }\end{array}$ & $\begin{array}{l}\text { Log Removal of } \\
\text { Each Step } \\
\end{array}$ \\
\hline Source water ${ }^{1}$ & $7.33 \times 10^{6}$ & -- \\
\hline Treated, unfiltered effluent ${ }^{1}$ & $1.75 \times 10^{4}$ & 2.70 \\
\hline Treated, filtered effluent ${ }^{1}$ & $9.00 \times 10^{2}$ & 1.22 \\
\hline Overall removal $^{1}$ & -- & 3.92 \\
\hline
\end{tabular}

Table 4.7: Coliform and E. coli concentration and log removal at each step in the treatment process with 2-ply nominal-absolute filter and a port screen during the Mock Challenge Water \#2 treatment attempt in experiment $\mathrm{H}-3$ at $20 \mathrm{~mL} / \mathrm{min}$ flowrate.

\begin{tabular}{|c|c|c|}
\hline Step in the Treatment Process & $\begin{array}{l}\text { Concentration } \\
\text { (MPN/100 mL) }\end{array}$ & $\begin{array}{l}\text { Log Removal of } \\
\text { Each Step }\end{array}$ \\
\hline Source water, coliform ${ }^{1}$ & $3.26 \times 10^{6}$ & -- \\
\hline Treated, unfiltered effluent, coliform ${ }^{1}$ & 2 & 6.44 \\
\hline Treated, filtered effluent, coliform ${ }^{1}$ & $<1$ & 0.30 \\
\hline Overall coliform removal ${ }^{1}$ & -- & 6.74 \\
\hline Source water, E. coli ${ }^{1}$ & $2.03 \times 10^{6}$ & -- \\
\hline Treated, unfiltered effluent, $E$. coli ${ }^{1}$ & 2 & 6.20 \\
\hline Treated, filtered effluent, $E . c{ }^{1} i^{1}$ & $<1$ & 0.30 \\
\hline Overall $E$. coli removal $^{1}$ & -- & 6.50 \\
\hline
\end{tabular}

${ }^{1}$ Two filters were tested at this flowrate, so average values are reported.

Due to the sufficient microsphere and bacteria log removal results, it was determined that the 2-ply nominal-absolute filter could meet the U.S. EPA Challenge Water \#2 removal 
requirements when a port screen was in place and the flowrate was reduced to 20

$\mathrm{mL} / \mathrm{min}$. Therefore, this would be the filter used for the official U.S. EPA Challenge test at BioVir Laboratories.

\subsubsection{Experiment I-1: Official EPA Challenge Water \#2 Attempt}

The 2-ply nominal-absolute (liquid fusion) filter was tested in triplicate against the U.S. EPA Microbiological Water Purifier Guide Standard and Testing Protocol at BioVir Laboratories on August 17, 2012. The purpose of this test was to determine if the 2-ply nominal-absolute (liquid fusion) filter could meet the pathogen removal requirements of Test Water \#2. The waterbags were filled with tap water first to ensure that all valves were set in the appropriate place to throttle the flowrate to $20 \mathrm{~mL} / \mathrm{min}$. Once the waterbags were calibrated to the correct flowrate, they were filled with Challenge Test Water \#2, dosed with one PŪR ${ }^{\circledR}$ sachet, mixed for five minutes at $100 \mathrm{bpm}$, allowed to settle and disinfect for $25 \mathrm{~min}$, and effluent was filtered and collected in cubitainers for further analysis. Two different effluent samples were collected, an unfiltered sample and a filtered sample, in order to determine removal capabilities of the 2-ply nominalabsolute (liquid fusion) filter.

Dr. Robert Cooper and his staff prepared the challenge test water and performed the analysis of the raw, treated-unfiltered, and treated-filtered samples. The initial microbiological concentrations in the raw water were $7.3 \times 10^{6}$ colony forming units $(\mathrm{CFU}) / 100 \mathrm{~mL}$ E. coli, $1.3 \times 10^{5}$ plaque forming units $(\mathrm{PFU}) / \mathrm{mL}$ coliphage, and $5.6 \times 10^{5}$ beads/L fluorescent microspheres. The E. coli, coliphage, and fluorescent microspheres represented the bacteria, virus, and protozoan oocyst elements of the Challenge Test (Cooper, 2012). Final removals of all three prototypes are listed in Table 4.8, Table 4.9, 
and Table 4.10. The bacteria, virus, and microsphere removal requirements were met in two of the three bag and filter combinations tested. The complete BioVir Laboratories Test Report for experiment I-1 can be found in Appendix D. Note, the flowrate for Bag 3 was the most variable during experiment I-1. This variability could have led to the poor removals observed.

Table 4.8: $E$. coli $(\mathrm{CFU} / 100 \mathrm{~mL})$ removal results (BioVir, 2012)

\begin{tabular}{ccccccc}
\hline \multirow{2}{*}{ Influent } & \multicolumn{2}{c}{ Bag 1 } & \multicolumn{2}{c}{ Bag 2 } & \multicolumn{2}{c}{ Bag 3 } \\
\cline { 2 - 7 } & $\begin{array}{c}\text { Bag } \\
\text { Effluent }\end{array}$ & $\begin{array}{c}\text { Post Filter } \\
\text { Effluent }\end{array}$ & $\begin{array}{c}\text { Bag } \\
\text { Effluent }\end{array}$ & $\begin{array}{c}\text { Post Filter } \\
\text { Effluent }\end{array}$ & $\begin{array}{c}\text { Bag } \\
\text { Effluent }\end{array}$ & $\begin{array}{c}\text { Post Filter } \\
\text { Effluent }\end{array}$ \\
\hline $\begin{array}{c}7.3 \times 10^{6} \\
\begin{array}{c}\text { Log } \\
\text { Reduction }\end{array}\end{array}$ & $<1$ & $<1$ & $<1$ & $<1$ & $1.5 \times 10^{4}$ & $2.2 \times 10^{2}$ \\
\hline
\end{tabular}

Table 4.9: Coliphage (PFU/mL) removal results (BioVir, 2012)

\begin{tabular}{ccccccc}
\hline \multirow{2}{*}{ Influent } & \multicolumn{2}{c}{ Bag 1 } & \multicolumn{2}{c}{ Bag 2 } & \multicolumn{2}{c}{ Bag 3 } \\
\cline { 2 - 7 } & $\begin{array}{c}\text { Bag } \\
\text { Effluent }\end{array}$ & $\begin{array}{c}\text { Post Filter } \\
\text { Effluent }\end{array}$ & $\begin{array}{c}\text { Bag } \\
\text { Effluent }\end{array}$ & $\begin{array}{c}\text { Post Filter } \\
\text { Effluent }\end{array}$ & $\begin{array}{c}\text { Bag } \\
\text { Effluent }\end{array}$ & $\begin{array}{c}\text { Post Filter } \\
\text { Effluent }\end{array}$ \\
\hline $\begin{array}{c}1.3 \times 10^{5} \\
\text { Log }\end{array}$ & $<1$ & $<1$ & $<1$ & $<1$ & 9 & 4 \\
Reduction & & $>5.1$ & & $>5.1$ & & $\geq 4.3$ \\
\hline
\end{tabular}

Table 4.10: Microsphere (Beads/L) removal results (BioVir, 2012)

\begin{tabular}{ccccccc}
\hline \multirow{2}{*}{ Influent } & \multicolumn{2}{c}{ Bag 1 } & \multicolumn{2}{c}{ Bag 2 } & \multicolumn{2}{c}{ Bag 3 } \\
\cline { 2 - 7 } & $\begin{array}{c}\text { Bag } \\
\text { Effluent }\end{array}$ & $\begin{array}{c}\text { Post Filter } \\
\text { Effluent }\end{array}$ & $\begin{array}{c}\text { Bag } \\
\text { Effluent }\end{array}$ & $\begin{array}{c}\text { Post Filter } \\
\text { Effluent }\end{array}$ & $\begin{array}{c}\text { Bag } \\
\text { Effluent }\end{array}$ & $\begin{array}{c}\text { Post Filter } \\
\text { Effluent }\end{array}$ \\
\hline $\begin{array}{c}5.6 \times 10^{5} \\
\text { Log }\end{array}$ & $7.7 \times 10^{3}$ & $<50 / \mathrm{L}$ & $7.0 \times 10^{3}$ & $1.2 \times 10^{2}$ & $4.4 \times 10^{3}$ & $<10$ \\
Reduction & 1.9 & $>4.1$ & 1.9 & 3.7 & 2.1 & 2.7 \\
\hline
\end{tabular}

When considering the variability in the microsphere results, it was noted that there was a small volume of water between the exit port and the clamp valve that might not get 
treated to the same extent as the majority of the water in the waterbag. The inconsistency of this volume among the triplicate bags could possibly be the cause of the variable results observed. Dr. Robert Cooper also reported that the lower bacteria log removal observed in Bag 3 could have been due to only $9 \mu \mathrm{L}$ of untreated source water contamination in the effluent cubitainer (Dr. Robert Cooper, personal communication, October, 2012).

Turbidity, $\mathrm{pH}$, and free chlorine residual were also measured on-site by Cal Poly researchers. The average initial turbidity value was 39.7 NTU, which satisfies the U.S. EPA Guide Standard and Testing Protocol. Unfiltered post-treatment turbidities varied slightly between Bag 1 and 2 and greatly between Bag 2 and 3 (Figure 4.20). The $\mathrm{pH}$ was 5.7 in Bag 1; $\mathrm{pH}$ of samples from Bag 2 and 3 was not measured. The free chlorine residual was 0.03 in Bags 1, 2, and 3. A low free chlorine residual is expected when test waters contain such high organic carbon content as that of U.S. EPA Challenge Water \#2.

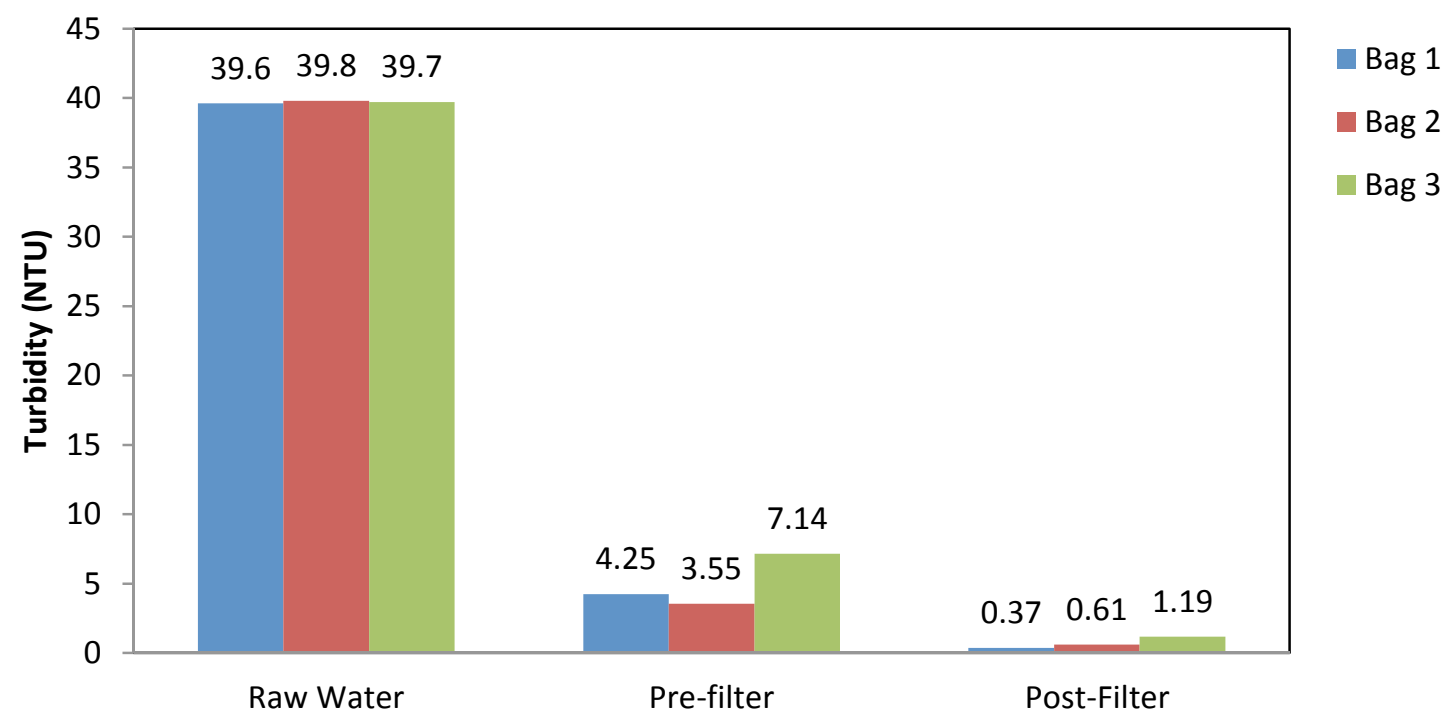

Figure 4.20: Turbidity of samples collected by Cal Poly researchers during the 2012 U.S. EPA Challenge Water test from waterbags tested in triplicate. 
The results of the U.S. EPA Challenge Water experiment showed that after treating a contaminated water source with one PŪR ${ }^{\circledR}$ sachet in the waterbag, the 2-ply nominalabsolute (liquid fusion) filter can successfully meet turbidity and pathogen (virus) reductions for emergency relief required by the U.S. EPA when used with a $20 \mathrm{~mL} / \mathrm{min}$ flowrate. These results are in contrast to both the initial BioVir testing in 2009 (Compas, 2009) and the most recent BioVir testing in 2010 (Herzog, 2011). The 2009 BioVir test found that effective treatment was not obtainable with one $\mathrm{P} \overline{\mathrm{UR}}{ }^{\circledR}$ sachet and a filter constructed of one layer of the nominal material (Compas, 2009). The 2010 BioVir test found that effective treatment was obtainable with two PURR ${ }^{\circledR}$ sachets and a filter made of one layer of the nominal material (Herzog, 2011). 


\section{CHAPTER 5: CONCLUSIONS}

The present thesis research aimed to design and develop a low-profile, low-cost, and effective cloth filter for use with the Cal Poly waterbag disaster relief system. Many design iterations were tested and an optimal filter design was developed over the course of 22 experiments. The performance of this optimal design was then characterized using challenge waters. While the new filter is promising, additional testing and characterization is needed as both high removal performance and a simultaneously high flowrate was not possible.

\subsection{Optimization and U.S. EPA Challenge Water}

Both the design experiments as well as the U.S. EPA Challenge Water experiments led to conclusions regarding filter design and construction for the waterbag. A properly functioning filter helps to remove disinfection-resistant organisms from the waterbag effluent. The experiments showed that an external 2-ply nominal-absolute filter (sealed with Liquid Fusion) gave the best performance when treating U.S. EPA Challenge Water \#2. The 2-ply nominal-absolute filter consisted of an internal plastic spacer, an inner layer of $1-\mu \mathrm{m}$ nominal filter cloth, and an outer layer of $1-\mu \mathrm{m}$ absolute filter cloth. However, the flowrate had to be throttled to $20 \mathrm{~mL} / \mathrm{min}$, and performance was inconsistent, perhaps due to non-optimal valves.

When tested in triplicate at BioVir, two out of three bag/filter combinations met and exceeded bacteria, viruses, and protozoa removal requirements (6-log removal, 4-log removal, and 3-log removal, respectively) while one bag only removed $4.5 \log$ of bacteria, $\geq 4.3 \log$ of viruses, and $2.7 \log$ of protozoa. These results contradict removals observed during mock Challenge Water \#2 experiments performed at Cal Poly. During 
experiment H-3, the 2-ply nominal-absolute filter (sealed with Liquid Fusion)

consistently met both bacteria and microsphere removal requirements when flowrate was throttled to $20 \mathrm{~mL} / \mathrm{min}$. The low bacteria and microsphere removals could have been due to leaks in the filter pouch, which could have allowed untreated water to drip into the cubitainers. Another possibility is that the initial volume of water caught in the tubing leading from the waterbag to the filter pouch is not adequately treated by the $\mathrm{PU}^{\circledR}{ }^{\circledR}$ sachet, resulting in untreated test water mixing with treated, filtered effluent.

Emergency relief guidelines specify a chlorine residual of $0.2-0.5 \mathrm{mg} / \mathrm{L}$ for POU treatment devices (Sphere Project, 2004 and WHO, 2006). The present thesis research also showed that when using one PŪR ${ }^{\circledR}$ sachet to treat water in the waterbag, a minimum chlorine residual of $0.2 \mathrm{mg} / \mathrm{L}$ was not obtained when using Challenge Water \#2 which has a high humic acid content to simulate very low quality source water.

\subsection{Future Research}

Future research on filters for the waterbag is suggested to better characterize the performance of the envelope filter when constructed of non-woven cloth. The influence on performance of the water volume held in the bag effluent tube should be examined. If this volume is not being sufficiently coagulated and disinfected, this volume should be decreased or eliminated. A bag effluent port with integrated valve is one possible way to do this. Another area that may deserve study is the effect of jostling the waterbag and filter during treatment. Jostling may dislodge cysts or flocs from the filter. In the present study, composite samples were used in the commercial lab testing. However, water quality is likely to change over the course of a run. Thus, grab samples taken at intervals over the course of a run might reveal that some aliquots are off-specification. Finally, if a 
filter backwashing procedure can be developed that is practical and effective, extended life and/or better water quality performance may be achievable.

Filter media that meets cyst removal goals at minimum low rates of about $200 \mathrm{~mL} / \mathrm{min}$, instead of the $20 \mathrm{~mL} / \mathrm{min}$ needed in the present study, should be sought. Currently available membrane filters, such as the Gravityworks filter, are ideal except for their high cost and bulkiness relative to the envelope filter.

Another way to evaluate filters is on a lifecycle cost basis. Although the upfront cost is high, existing membrane filters, such as the Gravityworks filter, if they have a long lifetime might be considered affordable. As suggested above for the envelope filter, backwashing procedures could be developed and performance and lifetime assessed. In this way, the lifecycle cost and performance of the envelope filter can be compared with commercial filters, which is a needed step prior to commercialization of an envelope filter. 


\section{REFERENCES}

BioVir Laboratories, Inc. (BioVir) (2012). Test Report: Polytech Waterbag Challenge, Project \#121132. Benicia, BioVir Laboratories.

CAWST. (2006). Filtration Technology. Retrieved March 2013, from CAWST: http://www.cawst.org/index.php?id=128

Clasen, T. \& Smith, L. (2005). The drinking water response to the Indian Ocean tsunami including the role of household water treatment. London School of Hygiene \& Tropical Medicine. Geneva: World Health Organization.

Clasen, T. (2007). Point-of-use water treatment in emergencies and development settings. London: London School of Hygiene \& Tropical Medicine, Department Infectious \& Tropical Diseases.

Colwell, R., Huq, A., Islam, M., Aziz, K., Yunus, M., Khan, N., Mahmud, A., Sack, R., Nair, G., Chakraborty, J., Sack, D., \& Russek-Cohen, E. (2003). Reduction of Cholera in Bangladeshi villages by simple filtration. Proceedings of the National Academy of Sciences of the United States of America. 100(3), 1051-1055.

Compas, T. (2009). Point-of-use water treatment device for disaster relief. (Master's thesis). California Polytechnic State University, San Luis Obispo.

DayOne Response (2012). Gear for after a natural disaster. Retrieved February 4, 2013, from http://dayoneresponse.com/press/gear-for-after-the-disaster/

Duncan Enterprises (2012). Liquid fusion clear urethane glue. Retrieved June 28, 2012 from http://duncan-enterprises.amazonwebstore.com/Liquid-Fusion-Clear-UrethaneGlue/M/B001HO8EP6.htm

Grainger (2011). Flat washers. Retrieved November 14, 2011, from http://www.grainger.com/Grainger/Flat-Washer-5XU62?Pid=search

Hach Company (2010). Water quality testing instruments and reagents for laboratory, portable, and on-line applications. Retrieved August 5, 2012, from http://www.hach.com/

Hach Company (2000). DR/890 colorimeter procedures manual. United States of America: $\mathrm{HACH}$. 
Herzog, M. (2011). Optimization of point-of-use water treatment device for disaster relief. (Master's thesis). California Polytechnic State University, San Luis Obispo.

Hutten, I (2007). Handbook of Non-Woven Filter Media. ( $1^{\text {st }}$ Ed.). Burlingham: Elsiever, Ltd.

IDEXX (2012). Colilert ${ }^{\circledR}$. Retrieved August 6, 2012, from http://www.idexx.com/view/xhtml/en_us/water/products/colilert.jsf?conversationId=5 64350

Jellison, K., Napotnik, J., Mayer, A., \& Lantagne, D. (2009). Efficacy of silver-treated ceramic filters for household water treatment. International Ceramic Pot Filter Workshop: WEF Disinfection 2009.

McMaster-Carr (2011). Miniature through-wall fittings. Retrieved September 26, 2011, from http://www.mcmaster.com/\#bulkhead-tank-fittings/=lmtuxm

Metcalf \& Eddy. (2003). Wastewater Engineering, Treatment and Reuse. (4 ${ }^{\text {th }}$ Ed.). New York: McGraw-Hill, Inc.

MWH. (2005). Water Treatment Principles and Design. (2 ${ }^{\text {nd }}$ Ed.). New Jersey: John Wiley \& Sons, Inc.

Procter \& Gamble. (2013). PUR packet. Children's safe drinking water. Retrieved February 28, 2013, from http://www.csdw.org/csdw/pur_packet.shtml

Rosedale Products, Inc. (Rosedale) (2011). Filter bag design details. Retrieved April 13, 2011, from http://www.rosedaleproducts.com/pdf/126128.pdf

Rosedale Produce, Inc. (Rosedale) (2012). Rosedale high-efficiency filter bags. Retrieved April 20, 2012, from http://www.rosedaleproducts.com/pdf/153155.pdf

Ryan Herco Flow Solutions (Ryan Herco) (2012). Miniature PVC tank adapters: tank adapters and bulkhead fittings. Retrieved July 11, 2012, from http://webcat.rhfs.com/familydetails.aspx?FamID=3130

Suthaker, Smith, \& Stanley (1998). Optimization of filter ripening sequence. Aqua, 47(3) 107-118. 
The Sphere Project. (2004). Humanitarian charter and minimum standards in disaster Response. Geneva: The Sphere Project.

U.S. Environment Protection Agency. (1987). Guide standard and protocol for testing microbiological water purifiers. Report of task force. U.S. Environmental Protection Agency.

U.S. Environmental Protection Agency (2013). Microbiological and chemical exposure assessment: Cryptosporidium and Giardia. Retrieved January 24, 2013, from http://www.epa.gov/nerlcwww/cpt_gda.html

Vestergard-Frandsten (2011). LifeStraw: Safe drinking water interventions for home and outside use. Retrieved March 3, 2013 from http://www.vestergaardfrandsen.com/lifestraw

WaterAid (2012). WaterAid in America annual report 2011/12. Retrieved February 5, 2013, from http://www.wateraidamerica.org/about_us/annual_report.aspx

Wilson, J., Boutilier, L., Jamieson, R., Havard, P., \& Lake, C. (2011). Effects of hydraulic loading rate and filter length on the performance of lateral flow sand filters for on-site wastewater treatment. Journal of Hydraulic Engineering, 16(8) 639-649.

Woodrow Wilson International Center for Scholars. (2006). Water stories: Expanding opportunities in small-scale water and sanitation projects. Washington, D.C.: Woodrow Wilson International Center for Scholars.

World Health Organization. (2006). Guidelines for drinking-water quality: incorporating first addendum. Vol. 1 recommendations, $3^{\text {rd }}$ Ed. Geneva: WHO Press. 


\section{APPENDIX A: NOMINAL FILTER CLOTH PRODUCT SHEET}

Product Sheet from Rosedale Products of California, Inc. for Standard Filter Bag. 


\section{T FILTER BAG}

\section{Design Details}

Standard Filter Bag Types

MOLDED ROSEDALE TOP BAGS are stocked with polypropylene tops in sizes 1 , 2, 3, 4, 8 \& 9 .

RING TOP BAGS are stocked in sizes 1, 2, $3,4,8,9 \& 12$ with galvanized steel, rings.

HANDLES are standard on all bags.

ALL STANDARD STOCK BAGS have sewn construction.

\section{FILTER BAG FINISH}

Felt filter bags are supplied with a glazed finish to reduce fiber migration. Mesh filter bags are supplied with a plain finish as woven.

Microfiber filter bags have spunbonded covers to prevent fiber migration.

\section{CONSTRUCTION}

Standard filter bags are typically manufactured with a metal ring, either galvanized carbon steel or stainless steel, sewn in the top of the filter bag. Woven fabric handles are also sewn.

Another design incorporates a molded plastic top. These tops typically are polypropylene or polyester with molded lifting handles. Various types of tops are available to fit specific manufacturers' housings.

\section{All Welded Construction}

All seams and the collar are sonically welded, enhancing filtration quality, eliminating leaks and bypass that may have occurred with sewn seams.
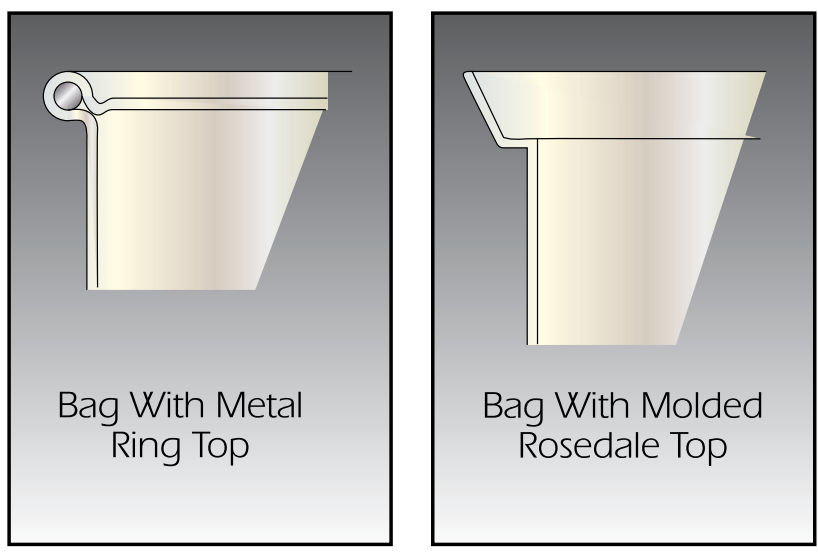

\begin{tabular}{|c|c|}
\hline $\begin{array}{c}\text { Nominal } \\
\text { Micron Rating- } \\
50 \%\end{array}$ & $\begin{array}{c}\text { High Efficiency } \\
\text { Micron Rating- } \\
95 \%\end{array}$ \\
\hline 1 & 35 \\
\hline 5 & 48 \\
\hline 10 & 55 \\
\hline 25 & 65 \\
\hline 50 & 70 \\
\hline 100 & 110 \\
\hline 200 & 200 \\
\hline
\end{tabular}

\section{Felt Filter Bag Micron Rating}

For years filter bag manufacturers have used nominal ratings, i.e., about 50\% efficiency for polyester and polypropylene felt filter bags. The table gives the micron ratings at about 95\% efficiency. 


\section{Filter Bag Pressure Drop}

The graphs give the clean pressure drop through a number 2 size bag for water, $1 \mathrm{CPS}$ @ $68^{\circ} \mathrm{F}$

To determine the pressure drop caused by the filter bag, follow these steps:

Step 1 Select the type of bag, micron rating and flow rate, determine the pressure drop for water, $1 \mathrm{cps} @ 68^{\circ} \mathrm{F}$, for a size \#2 bag.

Step 2 Correct for bag size from the Bag Size Correction table at the right if the bag size is different than a \#2 size.

Step 3 If the viscosity of the liquid is greater than 1 cps (water@ 68 ${ }^{\circ}$.), multiply the result from step 2 by the proper correction factor from the Viscosity Correction table at the right.

The value obtained in Step 3 is the clean pressure drop caused by the filter bag.

\section{SUMMARY}

For new applications, the clean pressure drop of the system, housing and bag should be 2.0 PSI or less. The lower the value is, the more contaminant a bag will hold. For applications with low dirt loading, this value can go to 3.0 PSI or more. Consult the factory for recommendations when the clean pressure drop of the system exceeds 3.0 PSI.
Felt \& Mesh Bags

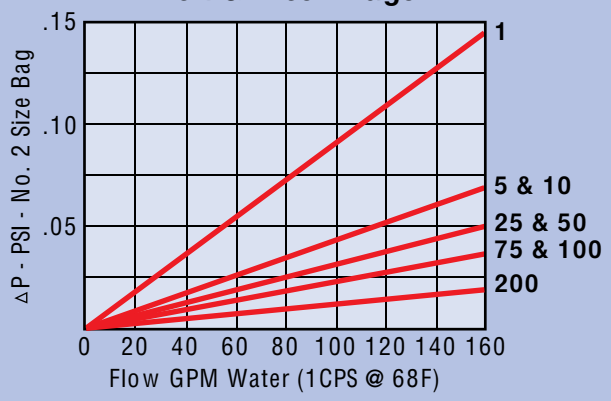

High Efficiency Bags

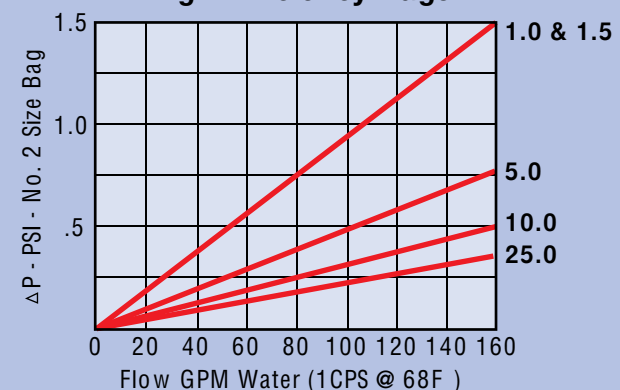

\begin{tabular}{|c|c|c|}
\hline \multicolumn{3}{|c|}{ Bag Slze Correction } \\
\hline $\begin{array}{c}\text { Bag } \\
\text { Size }\end{array}$ & Dla. x Length & $\begin{array}{c}\text { Multiply } \\
\text { By }\end{array}$ \\
\hline 1 & $7.2 \times 16$ & 2.25 \\
\hline 2 & $7.2 \times 32$ & 1.0 \\
\hline 3 & $4.3 \times 8$ & 9.0 \\
\hline 4 & $4.3 \times 14$ & 4.5 \\
\hline 8 & $5.7 \times 21$ & 2.25 \\
\hline 9 & $5.7 \times 37$ & 1.50 \\
\hline
\end{tabular}

\begin{tabular}{|l|c|}
\hline \multicolumn{2}{|c|}{ Viscosity Correction } \\
\hline Viscosity CPS & $\begin{array}{c}\text { Correction } \\
\text { Factor }\end{array}$ \\
\hline 50 & 4.5 \\
\hline 100 & 8.3 \\
\hline 200 & 16.6 \\
\hline 400 & 27.7 \\
\hline 800 & 50.0 \\
\hline 1000 & 56.2 \\
\hline 1500 & 77.2 \\
\hline 2000 & 113.6 \\
\hline 4000 & 161.0 \\
\hline 6000 & 250.0 \\
\hline 8000 & 325.0 \\
\hline 10,000 & 430.0 \\
\hline
\end{tabular}




\begin{tabular}{|c|c|c|c|c|c|c|c|c|c|c|c|c|c|c|c|c|c|c|c|c|c|}
\hline \multirow{2}{*}{ Construction } & \multirow{2}{*}{ Fiber } & \multicolumn{20}{|c|}{ Available Micron Ratings } \\
\hline & & 1 & 2.5 & 5 & 10 & 20 & 25 & 30 & 40 & 50 & 75 & 100 & 150 & 200 & 250 & 300 & 400 & 600 & 800 & 1000 & 1500 \\
\hline \multirow[b]{2}{*}{ Felts } & Polyester & & & & & & & & & & & & & & & & & & & & \\
\hline & $\begin{array}{l}\text { Polypro= } \\
\text { pylene }\end{array}$ & & & & & & & & & & & & & & & & & & & & \\
\hline $\begin{array}{l}\text { Multifilament } \\
\text { Meshes }\end{array}$ & Polyester & & & & & & & & & & & & & & & & & & & & \\
\hline $\begin{array}{l}\text { Monofilament } \\
\text { Meshes }\end{array}$ & Nylon & & & & & & & & & & & & & & & & & & & & \\
\hline $\begin{array}{l}\text { High- } \\
\text { Efficlency } \\
\text { Microfiber }\end{array}$ & $\begin{array}{l}\text { Polypro- } \\
\text { pylene }\end{array}$ & & & & & & & & & & & & & & & & & & & & \\
\hline Oll Removal & $\begin{array}{l}\text { Polypro= } \\
\text { pylene }\end{array}$ & & & & & & & & & & & & & & & & & & & & \\
\hline
\end{tabular}

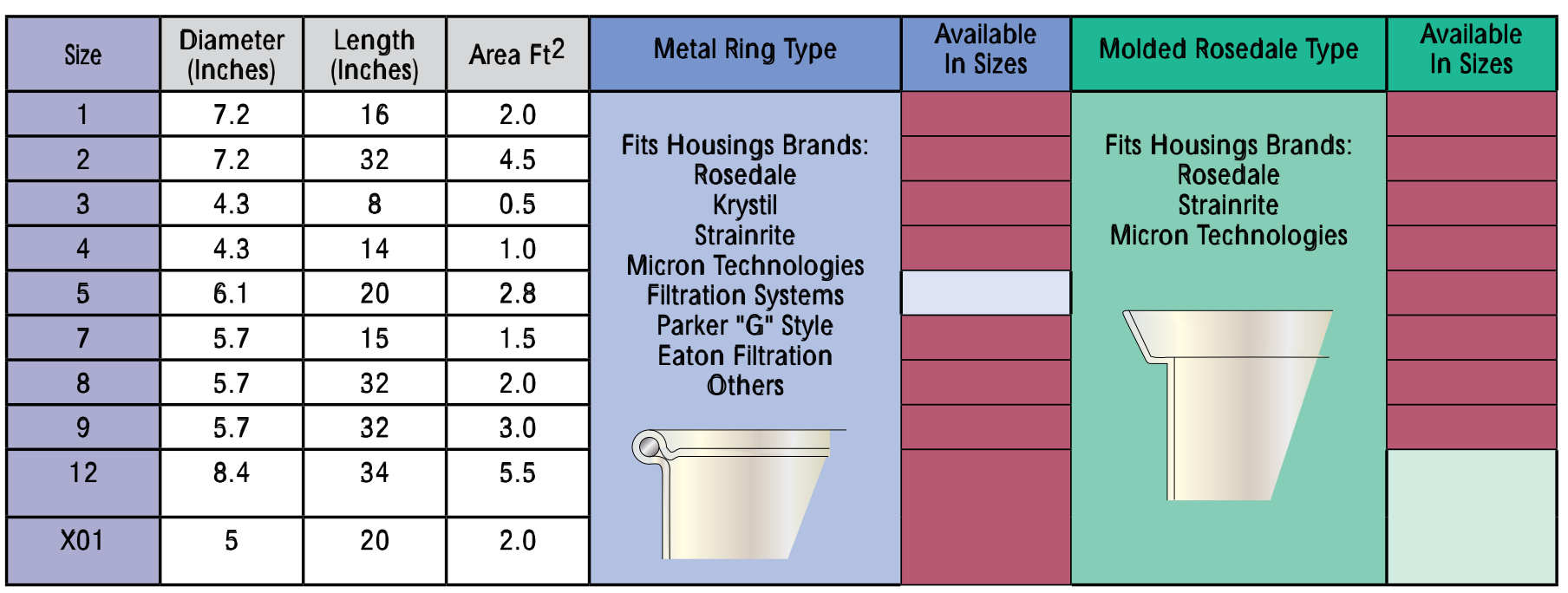




\section{MOLDED ROSEDALE TOPS - RPO STYLE}

Filter bags with molded Rosedale tops require no filter bag hold down devices. As the differential pressure in the application increases, the integrity of the seal improves. Polypropylene tops are standard with polyester optional for temperatures over $200^{\circ} \mathrm{F}$, or for chemical capatibility.

\section{THE MOLDED ROSEDALE TOP OFFERS THE BEST BAG-TO-HOUSING SEAL IN TODAY'S MARKETPLACE, IN ADDITION TO BEING THE EASIEST TO INSTALL AND REMOVE.}

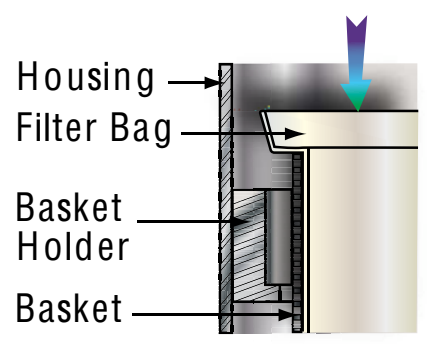

FILTER BAG WITH MOLDED ROSEDALE TOP JUST PRIOR TO INSTALLATION IN BASKET HOLDER

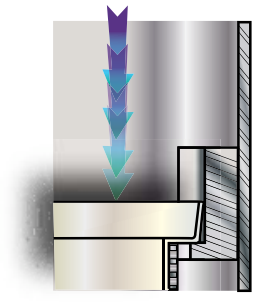

FILTER BAG WITH MOLDED ROSEDALE TOP INSTALLED IN HOUSING

\begin{tabular}{|c|c|c|}
\hline & $\begin{array}{l}\text { FELT filter bag materials are made from synthetic } \\
\text { fibers in polypropylene or polyester. The proper } \\
\text { combination of fiber diameters, weights and } \\
\text { thickness results in an economical depth type } \\
\text { filter medla. Polypropylene and polyester bags are } \\
\text { suppled with a glazed finish to reduce fiber } \\
\text { migration. These bags have a nominal micron } \\
\text { rating. Filter efficiency is about } 50 \% \text {. }\end{array}$ & Depth Felt Filter Media Traps Dirt Particles \\
\hline & $\begin{array}{l}\text { MULTIFILAMENT MESH materials are offered In } \\
\text { polyester and are woven from threads made of small } \\
\text { fibers twisted together. Bags made of this material are } \\
\text { low cost and considered disposable. They have lower } \\
\text { efficiencies than the monofilament mesh. } \\
\text { Filter efficiencies are about } 80 \% \text {. }\end{array}$ & Dirty \\
\hline & $\begin{array}{l}\text { MONOFILAMENT MESH is offered in nylon } \\
\text { and is a woven material. Each thread is a single } \\
\text { filament The openings are square,. They have } \\
\text { excellent strength and are considered to be } \\
\text { cleanable. Filter efficiency is } 90 \% \text { or more. }\end{array}$ & $\begin{array}{l}\text { - Operates on the principle of surface filtration } \\
\text { - Wide range of micron ratings } \\
\text { - Reusable or disposable } \\
\text { - Non-fiber releasing } \\
\text { - Good efficiencies } \\
\text { - High contaminant quantities under } \\
\text { correct conditions }\end{array}$ \\
\hline 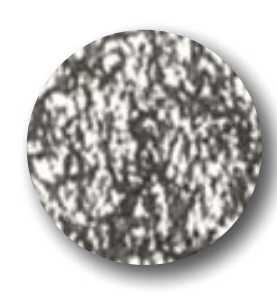 & $\begin{array}{l}\text { MICROFIBER filter bags provide high efficiency } \\
\text { and high contaminant holding capacity at low } \\
\text { ratings. Bags are available in polypropylene. } \\
\text { Filter efficiency is } 95 \% \text { or more. } \\
\text { MICROFIBER polypropylene filter bags also can } \\
\text { remove oil from water and other liquids. Optimized } \\
\text { designs are called "OIL REMOVAL BAGS". }\end{array}$ & $\begin{array}{l}\text { - Inner Cover } \\
\text { - Microfiber } \\
\text { Microfiber } \\
\text { Final Filter } \\
\text { Outer Cover } \\
\text { Spun Bonded }\end{array}$ \\
\hline
\end{tabular}




\section{OTHER BAG TYPES AND DESIGNS}

500 SERIES 3M TYPE multiple layer filter bags with microfiber filter layers and felt prefilter layers. Up to 5 layers of felt

DOUBLE \& TRIPLE LAYER felt bags where the micron rating of the layers are designed to optimize service life.

SPECIAL SIZE \& DESIGN bags are available in all materials and most micron ratings.

OIL REMOVAL BAGS require a special design to obtain to result in the largest surface area of fibers in a bag for maximum oil removal capacity. These are standard in micron ratings of 10 and 25 .

\section{FILTER BAG HOLD-DOWNS}

Adjustable filter bag hold-downs for Size \#1 and \#2 bags are available for side entry housings manufactured by:

Filter Specialists, Inc. / Micron Technologies / Krystil Klear / Strainrite / Other Side Entry Brands

Available in polypropylene, they provide additional positive filter bag hold-down capabilities for critical applications where necessary. It is suitable for ring top bags and bags with molded plastic tops. It is necessary for many bags with molded tops and ring bags if the bag manufacturer improperly designs and manufactures them.

A FILTER BAG HOLD-DOWN IS NOT REOUIRED WHEN USING FILTER BAGS WITH MOLDED ROSEDALE TOPS.

\section{If How To Order Build an ordering code as shown in the example}

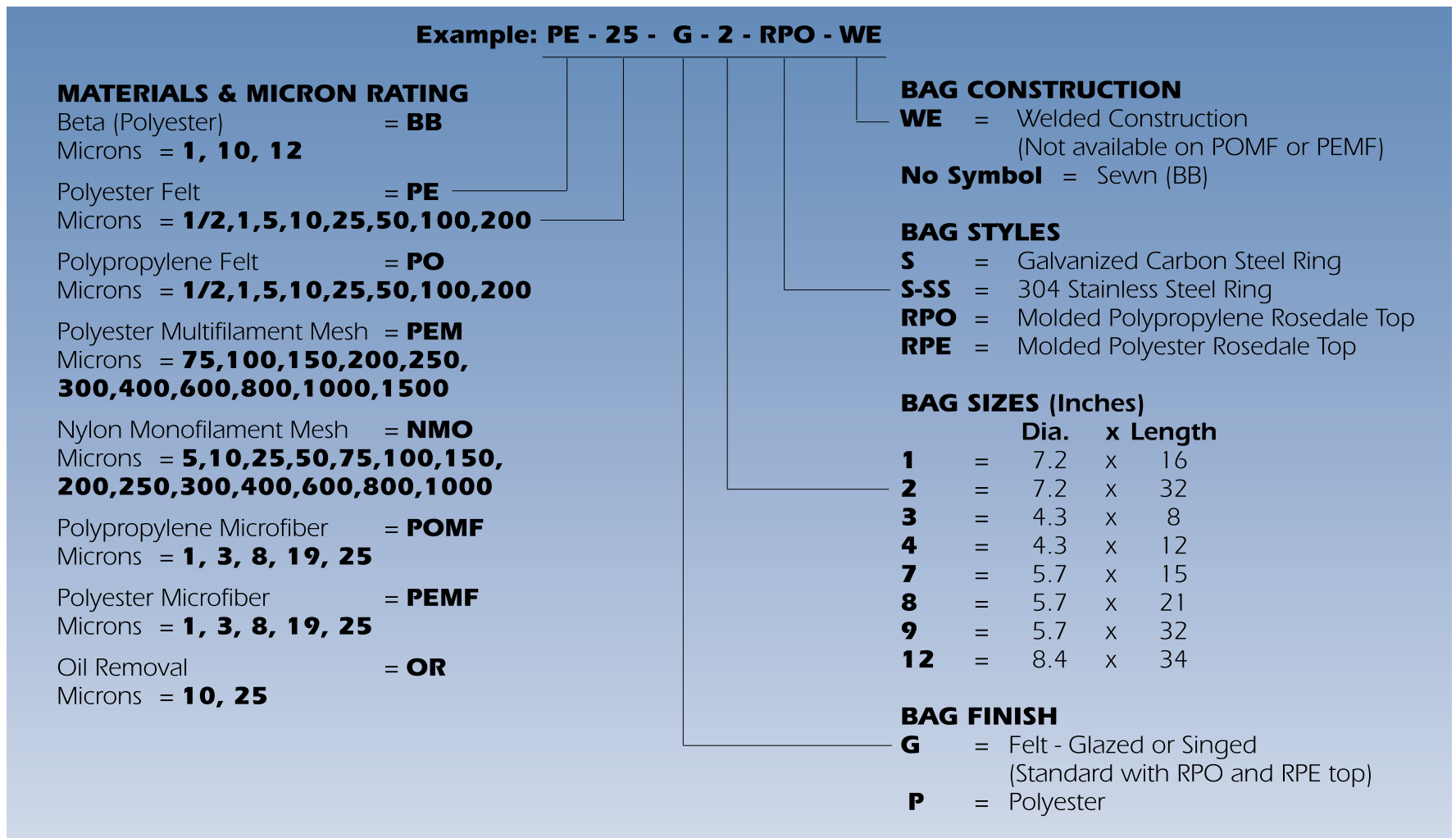




\section{APPENDIX B: ABSOLUTE FILTER CLOTH PRODUCT SHEET}

Product Sheet for Rosedale Products of California, Inc. High Efficiency Liquid Bags. 


\section{P R Rosedale High Efficiency Filter Bags}

Our HI-E series of bag filters meets the most stringent needs for fine process, hydraulic fluid, and lubricant filtration. All are made of unique microfiber materials, designed to increase the efficiency and dirt-holding capacities of these bags.

\section{Microfiber Material Construction}

Polyester or polypropylene microfibers and standard fibers are variably calendered to produce a single layer of microfiber material. Our unique construction can provide filtration to a 1 micron rating. Polyester microfiber material should be used where oil adsorption is not desirable or where higher temperatures are required.

\section{Filtration Level}

These bags have been tested by an independent laboratory to determine the filtration efficiency and dirt holding capabilities for each. They have been manufactured so that the efficiencies for both polyester and polypropylene are identical. See Filtration Efficiency Chart below.

\section{HI-E Series Filter Bags Using Microfiber Construction}

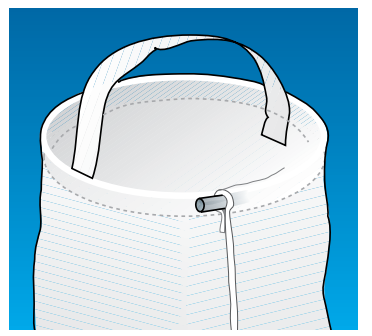

PEMF/POMF BAGS:

High Efficiency

Filtration using a single layer of microfiber material. Excellent for general polishing applications with low dirt load.

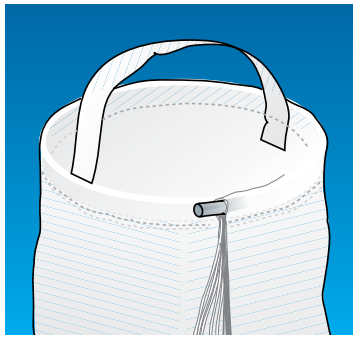

GRADED DENSITY BAGS: High Efficiency Filtration with multiple layers of microfiber material and pre-filtration layers. Has 4 times the dirt holding capacity of the PEMF/POMF series bags.

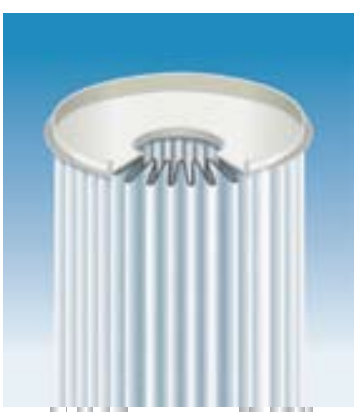

BAG-SIZE PLEATED CARTRIDGES:

High Efficiency Filtration with 12 times the dirt holding capacity and microfiber material supported by flowenhancing mesh. The extra surface area greatly increases the dirt holding capacity.

\section{Filtration Efficiency}

\begin{tabular}{|c|c|c|c|c|}
\hline Model Number & $\begin{array}{c}\text { PEMF } 1 \\
\text { POMF } 1 \\
523 \\
\text { PL PEMF } 1 \\
\text { PL POMF } 1\end{array}$ & $\begin{array}{c}\text { PEMF } 3 \\
\text { POMF } 3 \\
525 \\
\text { PL PEMF } 3 \\
\text { PL POMF } 3\end{array}$ & $\begin{array}{c}\text { PEMF } 8 \\
\text { POMF } 8 \\
527 \\
\text { PL PEMF } 8 \\
\text { PL POMF } 8\end{array}$ & $\begin{array}{l}\text { PEMF } 19 \\
\text { POMF } 19 \\
529 \\
\text { PL PEMF } 19 \\
\text { PL POMF } 19\end{array}$ \\
\hline EFFICIENCY & \multicolumn{4}{|c|}{ MICRON RATING } \\
\hline $\begin{array}{l}95 \% \\
99 \%\end{array}$ & $\begin{array}{l}1.0 \\
2.0\end{array}$ & $\begin{array}{l}3.0 \\
5.0\end{array}$ & $\begin{array}{c}8.0 \\
19.0\end{array}$ & $\begin{array}{l}19.0 \\
25.0\end{array}$ \\
\hline
\end{tabular}

* This test was conducted using AC Fine Test dirt interfaced into water at 10 GPM, Single-Pass. 
PEMF/POMF

\section{Series}

The microfiber bag is encased in spun-bonded material inside and out to prevent bag material migration into the fluid stream. Heavyduty handles for ease in removal are a standard feature. The fully shaped bottoms enhance the pressure capacities of these bags. THE PEMF/POMF SERIES HAS 4.4 SO. FT. OF SURFACE AREA.

\section{Bag-Sized Pleated}

\section{Cartridges}

With the PL Series pleated cartridges, we've combined the best features of bags and cartridges into one. It has the advantages of a bag; low in cost, easy to

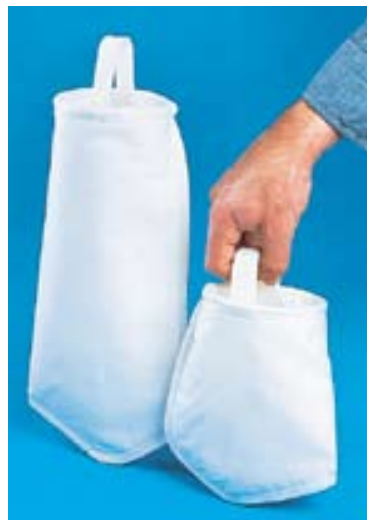
handle, and contaminant is trapped inside, but with the greater surface area and dirt-loading capabilities of pleated cartridges. The seams in these filter elements are ultrasonically welded, eliminating the problems associated with sewn seams. The microfiber material is sandwiched between two flow-enhancing polypropylene mesh screens, then pleated. The cartridge bottom and top sealing ring are made of solid molded polypropylene and are welded to the ends of the pleated cylinder without the use of adhesive. The sealing ring is a pliable gasket, increasing the efficiency and integrity of the seal. THE PL SERIES HAS 25 SQ. FT. OF SURFACE AREA.

\section{Dirt Holding Capacity}

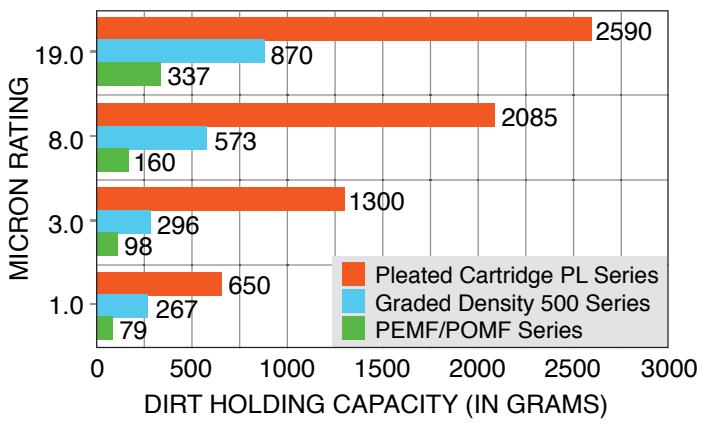

\section{Series, Graded Density Bags}

The 500 Series FAT BAGS® have approximately four times the dirt-holding capacity of our PEMF/ POMF series bags at equivalent filtrtion levels. You can now use bags, where performance levels previously required cartridges. These Graded Density Bags are made of multiple layers of microfibers and standard fibers variably calendered, providing filtration to 1 micron. Heavy-duty handles for ease in removal are a standard feature. The fully shaped bottoms enhance the pressure capacities of the bag. THE 500 SERIES HAS 9 LAYERS OF MICROFIBER MATERIAL, EACH WITH 4.4 SQ. FT. OF SURFACE AREA.

\begin{tabular}{|c|c|c|c|}
\hline \multicolumn{4}{|c|}{ Chemical Compatibilities } \\
\hline \multirow[t]{2}{*}{ EXCELLENT } & GOOD & FAIR & POOR \\
\hline & \multicolumn{3}{|c|}{ Bag Material (Fiber) } \\
\hline \multicolumn{4}{|l|}{ Organic Solvents } \\
\hline \multicolumn{4}{|l|}{$\begin{array}{l}\text { Animal Negetable } \\
\text { and Petro Oils }\end{array}$} \\
\hline \multicolumn{4}{|l|}{ Microorganisms } \\
\hline \multicolumn{4}{|l|}{ Alkalies } \\
\hline \multicolumn{4}{|l|}{ Organic Acids } \\
\hline \multicolumn{4}{|l|}{ Oxidizing Agents } \\
\hline \multicolumn{4}{|l|}{ Mineral Acids } \\
\hline \multicolumn{4}{|c|}{$\begin{array}{l}\text { Temperature Limitations, } 325^{\circ} \mathrm{F} \text { for Nylon and Polyes } \\
\text { ter, } 225^{\circ} \mathrm{F} \text { for Polypropylene. }\end{array}$} \\
\hline \multicolumn{4}{|c|}{$\begin{array}{l}\text { Note: For more complete information on chemical } \\
\text { compatibilities, refer to pages } 222 \text { through } 231 \text {. }\end{array}$} \\
\hline
\end{tabular}

\section{Pressure Drop}

Total pressure drop is the sum of the filter housing pressure drop plus the pressure drop through the bag, and is a function of viscosity as well as flow rate.

Using water as the test media, the pressure drop for these high-efficiency bags is less than 0.5 psi.

Little or no pressure drop across the filter element at rated flow yields maximum dirt holding capacity (element life). Increases in the pressure drop are then due solely to the particulate accumulation. 


\section{How To Order}

Build an ordering code as shown in these examples

\section{PEMF/POMF SERIES FILTER BAGS}

Example:

MICROFIBER MATERIAL

Polyester

= PEMF

Polypropylene

$=$ POMF

\section{MICRON RATING (95\%)}

1.0 micron

3.0 micron

8.0 micron

$=\mathbf{1}$

$=3$

$=8$

19.0 micron
PEMF - 3 - 2

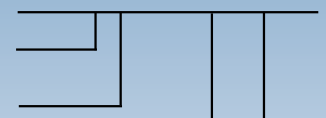

Symbol

$1=$

$\mathbf{2}=$

$3=$

$4=$

$7=$

$8=$

$9=$
BAG SIZE

(dimensions in inches)

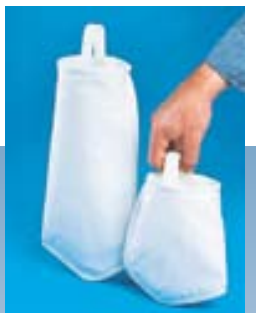

Dia.

$7-1 / 16 \quad x \quad 16$

$7-1 / 16 \quad x \quad 32$

4-1/8 $\quad x \quad 8$

4-1/8 $\quad x \quad 14$

$5-5 / 8 \quad x \quad 15$

$5-5 / 8 \quad x \quad 21$

$5-5 / 8 \quad x \quad 32$

\section{SERIES GRADED DENSITY BAGS}

Example:

Graded Density Bag MICROFIBER MATERIAL

Polyester

Polypropylene

$=$ PE

$=\mathbf{P O}$

MICRON RATING (95\%)

1.0 micron

3.0 micron

$=\mathbf{5 2 3}$

8.0 micron

$=525$

$=527$

19.0 micron
GD - PO - 523 - 1
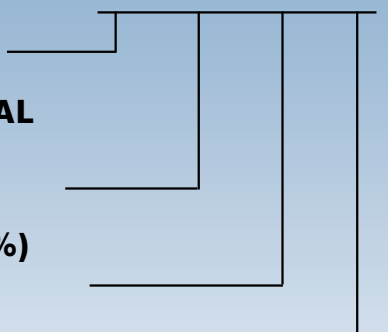

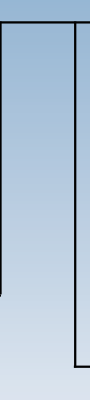

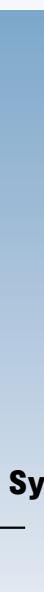

BAG SIZE

(dimensions in inches)

Symbol

$1=$

Dia.

$7-1 / 16$

$7-1 / 16$

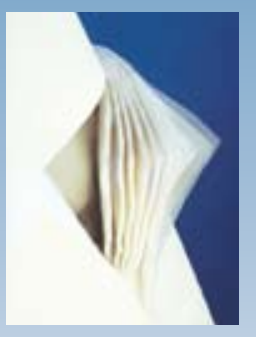

$x$ Length

$x \quad 16$

$\times \quad 32$

\section{PLEATED CARTRIDGES}

\section{Example: \\ PL- PEMF - R1 - 1 - P1}

MICROFIBER MATERIAL

Polyester

Polypropylene

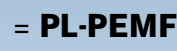

= PL-POMF

\section{TOP SEALING RING DESIGN}

Flared Polypropylene (P1-P2) $=\mathbf{R}$

Solid Polypropylene (P3-P9) = $\mathbf{R 2}$

MICRON RATING (95\%)

1.0 micron $\quad=1$

3.0 micron $\quad=3$

8.0 micron $\quad=8$

19.0 micron $\quad \mathbf{1 9}$

\section{BAG SIZE}

(dimensions in inches)

\begin{tabular}{|c|c|c|c|}
\hline Symbol & Dia. & $\mathbf{x}$ & Length \\
\hline $\mathbf{P 1}=$ & $7-1 / 16$ & $x$ & $11-1 / 8$ \\
\hline P2 = & $7-1 / 16$ & $x$ & $26-1 / 8$ \\
\hline P3 = & $4-1 / 8$ & $x$ & $5-1 / 16$ \\
\hline P4 = & $4-1 / 8$ & $x$ & $11-1 / 16$ \\
\hline P7 = & $5-5 / 8$ & $x$ & $10-3 / 4$ \\
\hline P8 = & $5-5 / 8$ & $x$ & $16-1 / 8$ \\
\hline P9 = & $5-5 / 8$ & $x$ & $26-3 /$ \\
\hline
\end{tabular}




\section{APPENDIX C: FLOW VS. HEAD DATA}

\section{EXPERIMENT A-1 DATA}

\begin{tabular}{|c|c|c|c|c|c|c|c|c|c|c|}
\hline Water & $\begin{array}{l}\text { Total Vol. } \\
\text { Filtered } \\
\text { (L) }\end{array}$ & $\begin{array}{l}\text { Turbidity } \\
\text { (NTU) }\end{array}$ & \begin{tabular}{|c} 
Vol. of \\
Water \\
Discharged \\
(L) \\
\end{tabular} & $\begin{array}{c}\text { Volume of } \\
\text { Water } \\
(\mathrm{mL})\end{array}$ & Time (sec) & Time (min) & $\begin{array}{c}\text { Flowrate } \\
\text { (L/sec) }\end{array}$ & $\begin{array}{l}\text { Flowrate } \\
(\mathrm{mL} / \mathrm{min})\end{array}$ & Ho (inch) & $\mathrm{Hn}$ (inch) \\
\hline \multirow[t]{10}{*}{$\begin{array}{c}\text { Raw } \\
\text { Water }\end{array}$} & 0 & & 0 & 0 & o & 0 & \#DIV/O! & 0 & & 35.00 \\
\hline & 1 & 1.46 & 0.1 & 100 & 2.1 & 0.035 & 0.04762 & 2857.14 & 35.00 & 34.25 \\
\hline & 2 & 1.36 & 1 & 1000 & 21.7 & 0.362 & 0.04608 & 2764.98 & 34.25 & 33.00 \\
\hline & 3 & 1.31 & 1 & 1000 & 22.3 & 0.372 & 0.04484 & 2690.58 & 33.00 & 31.75 \\
\hline & 4 & 1.36 & 1 & 1000 & 23.5 & 0.392 & 0.04255 & 2553.19 & 31.75 & 30.50 \\
\hline & 5 & 1.78 & 1 & 1000 & 27 & 0.450 & 0.03704 & 2222.22 & 30.50 & 29.00 \\
\hline & 6 & 1.68 & 1 & 1000 & 27 & 0.450 & 0.03704 & 2222.22 & 29.00 & 27.50 \\
\hline & 7.1 & 1.61 & 1.1 & 1100 & 32 & 0.533 & 0.03438 & 2062.50 & 27.50 & 25.50 \\
\hline & 8 & 1.53 & 0.9 & 900 & 35 & 0.583 & 0.02571 & 1542.86 & 25.50 & 23.00 \\
\hline & 9 & 1.52 & 1 & 1000 & 80.3 & 1.338 & 0.01245 & 747.20 & 23.00 & 20.00 \\
\hline
\end{tabular}

INTERNAL FILTER (Bag 1) - Run 2

\begin{tabular}{|c|c|c|c|c|c|c|c|c|c|c|}
\hline Water & $\begin{array}{l}\text { Total Vol. } \\
\text { Filtered } \\
\text { (L) }\end{array}$ & $\begin{array}{c}\text { Turbidity } \\
\text { (NTU) }\end{array}$ & \begin{tabular}{|c|}
$\begin{array}{c}\text { Vol. of } \\
\text { Water } \\
\text { Discharged } \\
\text { (L) }\end{array}$ \\
\end{tabular} & $\begin{array}{c}\text { Volume of } \\
\text { Water } \\
(\mathrm{mL})\end{array}$ & Time (sec) & Time $(\min )$ & $\begin{array}{c}\text { Flowrate } \\
\text { (L/sec) }\end{array}$ & $\begin{array}{l}\text { Flowrate } \\
(\mathrm{mL} / \mathrm{min})\end{array}$ & Ho (inch) & Hn (inch) \\
\hline \multirow[t]{10}{*}{$\begin{array}{c}\text { Raw } \\
\text { Water }\end{array}$} & 0 & & 0 & 0 & 0 & 0 & \#DIV/O! & 이 & & $\mathrm{N} / \mathrm{M}$ \\
\hline & 1 & & 1 & 1000 & 20 & 0.333 & 0.05000 & 3000.00 & $\mathrm{~N} / \mathrm{M}$ & $\mathrm{N} / \mathrm{M}$ \\
\hline & 2 & & 1 & 1000 & 22 & 0.367 & 0.04545 & 2727.27 & $\mathrm{~N} / \mathrm{M}$ & $\mathrm{N} / \mathrm{M}$ \\
\hline & 3 & & 1 & 1000 & 23 & 0.383 & 0.04352 & 2610.97 & $\mathrm{~N} / \mathrm{M}$ & $\mathrm{N} / \mathrm{M}$ \\
\hline & 4 & & 1 & 1000 & 52 & 0.867 & 0.01923 & 1153.85 & $\mathrm{~N} / \mathrm{M}$ & $\mathrm{N} / \mathrm{M}$ \\
\hline & 5 & & 1 & 1000 & 30 & 0.500 & 0.03333 & 2000.00 & $\mathrm{~N} / \mathrm{M}$ & $\mathrm{N} / \mathrm{M}$ \\
\hline & 6 & & 1 & 1000 & 31 & 0.517 & 0.03226 & 1935.48 & $\mathrm{~N} / \mathrm{M}$ & $\mathrm{N} / \mathrm{M}$ \\
\hline & 7 & & 1 & 1000 & 34 & 0.567 & 0.02941 & 1764.71 & $\mathrm{~N} / \mathrm{M}$ & $\mathrm{N} / \mathrm{M}$ \\
\hline & 8 & & 1 & 1000 & 42 & 0.700 & 0.02381 & 1428.57 & $\mathrm{~N} / \mathrm{M}$ & $\mathrm{N} / \mathrm{M}$ \\
\hline & 9 & 1.46 & 1 & 1000 & 180 & 3.000 & 0.00556 & 333.33 & $\mathrm{~N} / \mathrm{M}$ & $\mathrm{N} / \mathrm{M}$ \\
\hline
\end{tabular}




\begin{tabular}{|c|c|c|c|c|r|r|r|r|r|r|}
\hline \multicolumn{1}{|c|}{ INTERNAL FILTER (Bag \# 1) - Run 3 } \\
\hline Water & $\begin{array}{c}\text { Total Vol. } \\
\text { Filtered } \\
\text { (L) }\end{array}$ & $\begin{array}{c}\text { Turbidity } \\
\text { (NTU) }\end{array}$ & $\begin{array}{c}\text { Vol. of } \\
\text { Water } \\
\text { Discharged } \\
\text { (L) }\end{array}$ & $\begin{array}{c}\text { Volume of } \\
\text { Water } \\
\text { (mL) }\end{array}$ & Time (sec) & Time (min) & $\begin{array}{c}\text { Flowrate } \\
\text { (L/sec) }\end{array}$ & $\begin{array}{c}\text { Flowrate } \\
\text { (mL/min) }\end{array}$ & Ho (inch) & Hn (inch) \\
\hline $\begin{array}{c}\text { Raw } \\
\text { Water }\end{array}$ & 0 & & 0 & 0 & 0 & 0 & \#DIV/0! & 0 & & 34.50 \\
\hline & 2 & 0.74 & 2 & 2000 & 42 & 0.700 & 0.04762 & 2857.14 & 34.50 & 32.50 \\
\hline & 4 & 0.66 & 2 & 2000 & 50 & 0.833 & 0.04000 & 2400.00 & 32.50 & 30.25 \\
\hline & 6 & 0.56 & 2 & 2000 & 59 & 0.983 & 0.03390 & 2033.90 & 30.25 & 27.50 \\
\hline & 8 & 0.60 & 2 & 2000 & 71 & 1.183 & 0.02817 & 1690.14 & 27.50 & 23.75 \\
\hline & 9.65 & 0.64 & 1.65 & 1650 & 175 & 2.917 & 0.00943 & 565.71 & 23.75 & 18.00 \\
\hline Notes:
\end{tabular}

\begin{tabular}{|c|c|c|c|c|c|c|c|c|c|c|}
\hline \multicolumn{11}{|c|}{ INTERNAL FILTER (Bag \#1) - Run 4} \\
\hline Water & $\begin{array}{l}\text { Vol. } \\
\text { Filtered } \\
\text { (L) }\end{array}$ & $\begin{array}{c}\text { Turbidity } \\
\text { (NTU) }\end{array}$ & \begin{tabular}{|c|}
$\begin{array}{c}\text { Vol. of } \\
\text { Water } \\
\text { Discharged } \\
\text { (L) }\end{array}$ \\
\end{tabular} & $\begin{array}{c}\text { Volume of } \\
\text { Water } \\
(\mathrm{mL})\end{array}$ & Time (sec) & Time $(\min )$ & $\begin{array}{c}\text { Flowrate } \\
\text { (L/sec) }\end{array}$ & $\begin{array}{l}\text { Flowrate } \\
(\mathrm{mL} / \mathrm{min})\end{array}$ & Ho (inch) & $\mathrm{Hn}$ (inch) \\
\hline \multirow[t]{6}{*}{$\begin{array}{c}\text { Raw } \\
\text { Water }\end{array}$} & 0 & & 0 & 0 & 0 & 0 & \#DIV/O! & 0 & & 34.75 \\
\hline & 2 & 0.48 & 2 & 2000 & 45 & 0.750 & 0.04444 & 2666.67 & 34.75 & 32.75 \\
\hline & 4 & 0.39 & 2 & 2000 & 50 & 0.833 & 0.04000 & 2400.00 & 32.75 & 31.00 \\
\hline & 6 & 0.38 & 2 & 2000 & 59 & 0.983 & 0.03390 & 2033.90 & 31.00 & 28.50 \\
\hline & 8 & 0.43 & 2 & 2000 & 74 & 1.233 & 0.02703 & 1621.62 & 28.50 & 25.50 \\
\hline & 10 & 0.52 & 2 & 2000 & 150 & 2.500 & 0.01333 & 800.00 & 25.50 & 18.50 \\
\hline \multicolumn{11}{|l|}{ Notes: } \\
\hline
\end{tabular}

\begin{tabular}{|c|c|c|c|c|c|c|c|c|c|c|}
\hline \multicolumn{11}{|c|}{ INTERNAL FILTER (Bag \#1) - Run 5} \\
\hline Water & $\begin{array}{c}\text { Vol. } \\
\text { Filtered } \\
\text { (L) }\end{array}$ & $\begin{array}{l}\text { Turbidity } \\
\text { (NTU) }\end{array}$ & \begin{tabular}{|c|} 
Vol. of \\
Water \\
Discharged \\
(L)
\end{tabular} & $\begin{array}{c}\text { Volume of } \\
\text { Water } \\
(\mathrm{mL})\end{array}$ & Time $(\mathrm{sec})$ & Time $(\min )$ & $\begin{array}{c}\text { Flowrate } \\
\text { (L/sec) }\end{array}$ & $\begin{array}{l}\text { Flowrate } \\
(\mathrm{mL} / \mathrm{min})\end{array}$ & Ho (inch) & $\mathrm{Hn}$ (inch) \\
\hline \multirow[t]{6}{*}{$\begin{array}{c}\text { Raw } \\
\text { Water }\end{array}$} & 0 & & 0 & 0 & 0 & 0 & \#DIV/0! & 0 & & 34.25 \\
\hline & 2 & 0.54 & 2 & 2000 & 45 & 0.750 & 0.04444 & 2666.67 & 34.25 & 32.50 \\
\hline & 4 & 0.45 & 2 & 2000 & 52 & 0.867 & 0.03846 & 2307.69 & 32.50 & 30.25 \\
\hline & 6 & 0.53 & 2 & 2000 & 59 & 0.983 & 0.03390 & 2033.90 & 30.25 & 28.00 \\
\hline & 8 & 0.47 & 2 & 2000 & 68 & 1.133 & 0.02941 & 1764.71 & 28.00 & 24.75 \\
\hline & 10 & 0.70 & 2 & 2000 & 137 & 2.283 & 0.01460 & 875.91 & 24.75 & 18.25 \\
\hline \multicolumn{11}{|l|}{ Notes: } \\
\hline
\end{tabular}


For Runs 6-12, head was measured incorrectly. Head was measured from the outlet port on the waterbag instead of from the ground.

\begin{tabular}{|c|c|c|c|c|r|r|r|r|r|r|}
\hline INTERNAL FILTER (Bag 1) - Run 6 \\
\hline Water & $\begin{array}{c}\text { Total Vol. } \\
\text { Filtered } \\
\text { (L) }\end{array}$ & $\begin{array}{c}\text { Turbidity } \\
\text { (NTU) }\end{array}$ & $\begin{array}{c}\text { Vol. of } \\
\text { Water } \\
\text { Discharged } \\
\text { (L) }\end{array}$ & $\begin{array}{c}\text { Volume of } \\
\text { Water } \\
\text { (mL) }\end{array}$ & Time (sec) & Time (min) & $\begin{array}{c}\text { Flowrate } \\
\text { (L/sec) }\end{array}$ & $\begin{array}{c}\text { Flowrate } \\
\text { (mL/min) }\end{array}$ & Ho (inch) & Hn (inch) \\
\hline $\begin{array}{c}\text { Raw } \\
\text { Water }\end{array}$ & 0 & 416 & 0 & 0 & 0 & 0 & \#DIV/0! & 0 & & 15.75 \\
\hline & 2 & 1.00 & 2 & 2000 & 50 & 0.833 & 0.04000 & 2400.00 & 15.75 & 13.50 \\
\hline & 4 & 1.02 & 2 & 2000 & 58 & 0.967 & 0.03448 & 2068.97 & 13.50 & 11.00 \\
\hline & 6 & 0.98 & 2 & 2000 & 68 & 1.133 & 0.02941 & 1764.71 & 11.00 & 8.75 \\
\hline \\
\hline
\end{tabular}

\begin{tabular}{|c|c|c|c|c|r|r|r|r|r|r|}
\hline INTERNAL FILTER (Bag 1) - Run 7 \\
\hline Water & $\begin{array}{c}\text { Total Vol. } \\
\text { Filtered } \\
\text { (L) }\end{array}$ & $\begin{array}{c}\text { Turbidity } \\
\text { (NTU) }\end{array}$ & $\begin{array}{c}\text { Vol. of } \\
\text { Water } \\
\text { Discharged } \\
\text { (L) }\end{array}$ & $\begin{array}{c}\text { Volume of } \\
\text { Water } \\
\text { (mL) }\end{array}$ & Time (sec) & Time (min) & $\begin{array}{c}\text { Flowrate } \\
\text { (L/sec) }\end{array}$ & $\begin{array}{c}\text { Flowrate } \\
\text { (mL/min) }\end{array}$ & Ho (inch) & Hn (inch) \\
\hline $\begin{array}{c}\text { Raw } \\
\text { Water }\end{array}$ & 0 & 411 & 0 & 0 & 0 & 0 & \#DIV/0! & 0 & & 16.00 \\
\hline & 2 & 0.85 & 2 & 2000 & 52 & 0.867 & 0.03846 & 2307.69 & 16.00 & 14.25 \\
\hline & 4 & 0.79 & 2 & 2000 & 59 & 0.983 & 0.03390 & 2033.90 & 14.25 & 12.00 \\
\hline & 6 & 0.89 & 2 & 2000 & 69 & 1.150 & 0.02899 & 1739.13 & 12.00 & 9.25 \\
\hline \\
\hline
\end{tabular}

\begin{tabular}{|c|c|c|c|c|r|r|r|r|r|r|}
\hline $\mathbf{1}$ um NOMINAL FILTER (Bag 1) - Run 8 & \multicolumn{1}{|c|}{$\begin{array}{c}\text { Vol. of } \\
\text { Water }\end{array}$} & $\begin{array}{c}\text { Total Vol. } \\
\text { Filtered } \\
\text { (L) }\end{array}$ & $\begin{array}{c}\text { Turbidity } \\
\text { (NTU) }\end{array}$ & $\begin{array}{c}\text { Volume of } \\
\text { Discharged } \\
\text { Water } \\
\text { (L) }\end{array}$ & Time (sec) & Time (min) & $\begin{array}{c}\text { Flowrate } \\
\text { (L/sec) }\end{array}$ & $\begin{array}{c}\text { Flowrate } \\
\text { (mL/min) }\end{array}$ & Ho (inch) & Hn (inch) \\
\hline $\begin{array}{c}\text { Raw } \\
\text { Water }\end{array}$ & 0 & 503 & 0 & 0 & 0 & 0 & \#DIV/0! & 0 & & 16.50 \\
\hline & 2 & 0.45 & 2 & 2000 & 55 & 0.917 & 0.03636 & 2181.82 & 16.50 & 14.75 \\
\hline & 4 & 0.48 & 2 & 2000 & 63 & 1.050 & 0.03175 & 1904.76 & 14.75 & 12.00 \\
\hline & 6 & 0.41 & 2 & 2000 & 80 & 1.333 & 0.02500 & 1500.00 & 12.00 & 9.00 \\
\hline & 8 & 0.45 & 2 & 2000 & 121 & 2.017 & 0.01653 & 991.74 & 9.00 & 5.50 \\
\hline & 8.775 & 0.43 & 0.775 & 775 & 120 & 2.000 & 0.00646 & 387.50 & 5.50 & 1.50 \\
\hline Notes:
\end{tabular}


1 um NOMINAL FILTER (Bag 1) - Run 9

\begin{tabular}{|c|c|c|c|c|c|c|c|c|c|c|}
\hline Water & $\begin{array}{l}\text { Total Vol. } \\
\text { Filtered } \\
\text { (L) }\end{array}$ & $\begin{array}{c}\text { Turbidity } \\
\text { (NTU) }\end{array}$ & $\begin{array}{c}\text { Vol. of } \\
\text { Water } \\
\text { Discharged } \\
\text { (L) }\end{array}$ & $\begin{array}{c}\text { Volume of } \\
\text { Water } \\
(\mathrm{mL})\end{array}$ & Time (sec) & Time $(\min )$ & $\begin{array}{c}\text { Flowrate } \\
\text { (L/sec) }\end{array}$ & $\begin{array}{l}\text { Flowrate } \\
(\mathrm{mL} / \mathrm{min})\end{array}$ & Ho (inch) & $\mathrm{Hn}$ (inch) \\
\hline \multirow[t]{6}{*}{$\begin{array}{c}\text { Raw } \\
\text { Water }\end{array}$} & 0 & 466 & 0 & 0 & 0 & 이 & \#DIV/O! & 0 & & 16.50 \\
\hline & 2 & 9.09 & 2 & 2000 & 64 & 1.067 & 0.03125 & 1875.00 & 16.50 & 14.50 \\
\hline & 4 & 1.29 & 2 & 2000 & 74 & 1.233 & 0.02703 & 1621.62 & 14.50 & 11.00 \\
\hline & 6 & 0.65 & 2 & 2000 & 98 & 1.633 & 0.02041 & 1224.49 & 11.00 & 8.00 \\
\hline & 8 & 0.85 & 2 & 2000 & 169 & 2.817 & 0.01183 & 710.06 & 8.00 & 4.25 \\
\hline & 8.8 & 0.94 & 0.8 & 800 & 217 & 3.617 & 0.00369 & 221.20 & 4.25 & 0.50 \\
\hline
\end{tabular}

Notes: Initial turbidity incredibly high. I hypothesize that there was a smudge or fingerprint on the glass vial causing the high turbidity.

1 um NOMINAL FILTER (Bag 1) - Run 10

\begin{tabular}{|c|c|c|c|r|r|r|r|r|r|r|}
\hline Water & $\begin{array}{c}\text { Total Vol. } \\
\text { Filtered } \\
\text { (L) }\end{array}$ & $\begin{array}{c}\text { Turbidity } \\
\text { (NTU) }\end{array}$ & $\begin{array}{c}\text { Vol. of } \\
\text { Water } \\
\text { Discharged } \\
\text { (L) }\end{array}$ & $\begin{array}{c}\text { Volume of } \\
\text { Water } \\
(\mathbf{m L})\end{array}$ & Time (sec) & Time (min) & $\begin{array}{c}\text { Flowrate } \\
\text { (L/sec) }\end{array}$ & $\begin{array}{c}\text { Flowrate } \\
\text { (mL/min) }\end{array}$ & Ho (inch) & Hn (inch) \\
\hline $\begin{array}{c}\text { Raw } \\
\text { Water }\end{array}$ & 0 & 420 & 0 & 0 & 0 & 0 & \#DIV/0! & 0 & & 16.00 \\
\hline & 2 & 0.96 & 2 & 2000 & 78 & 1.300 & 0.02564 & 1538.46 & 16.00 & 13.50 \\
\hline & 4 & 0.39 & 2 & 2000 & 97 & 1.617 & 0.02062 & 1237.11 & 13.50 & 10.50 \\
\hline & 6 & 0.40 & 2 & 2000 & 141 & 2.350 & 0.01418 & 851.06 & 10.50 & 8.25 \\
\hline & 8 & 0.41 & 2 & 2000 & 246 & 4.100 & 0.00813 & 487.80 & 8.25 & 3.50 \\
\hline & 8.6 & 0.67 & 0.6 & 600 & 142 & 2.367 & 0.00423 & 253.52 & 3.50 & 0.75 \\
\hline Notes: & & & & & & & & \\
\hline
\end{tabular}

\section{1 um NOMINAL FILTER (Bag 1) - Run 11}

\begin{tabular}{|c|c|c|c|c|c|c|c|c|c|c|}
\hline Water & $\begin{array}{l}\text { Total Vol. } \\
\text { Filtered } \\
\text { (L) }\end{array}$ & $\begin{array}{l}\text { Turbidity } \\
\text { (NTU) }\end{array}$ & \begin{tabular}{|c|}
$\begin{array}{c}\text { Vol. of } \\
\text { Water } \\
\text { Discharged } \\
\text { (L) }\end{array}$ \\
\end{tabular} & $\begin{array}{c}\text { Volume of } \\
\text { Water } \\
(\mathrm{mL})\end{array}$ & Time (sec) & Time $(\min )$ & $\begin{array}{c}\text { Flowrate } \\
\text { (L/sec) }\end{array}$ & $\begin{array}{l}\text { Flowrate } \\
(\mathrm{mL} / \mathrm{min})\end{array}$ & Ho (inch) & $\mathrm{Hn}$ (inch) \\
\hline \multirow[t]{6}{*}{$\begin{array}{c}\text { Raw } \\
\text { Water }\end{array}$} & 0 & 453 & 0 & 0 & 0 & 0 & \#DIV/O! & 0 & & 16.25 \\
\hline & 2 & 2.62 & 2 & 2000 & 88 & 1.467 & 0.02273 & 1363.64 & 16.25 & 13.75 \\
\hline & 4 & 0.87 & 2 & 2000 & 107 & 1.783 & 0.01869 & 1121.50 & 13.75 & 10.50 \\
\hline & 6 & 0.65 & 2 & 2000 & 150 & 2.500 & 0.01333 & 800.00 & 10.50 & 8.00 \\
\hline & 8 & 0.74 & 2 & 2000 & 234 & 3.900 & 0.00855 & 512.82 & 8.00 & 4.00 \\
\hline & 8.85 & 0.64 & 0.85 & 850 & 240 & 4.000 & 0.00354 & 212.50 & 4.00 & 0.50 \\
\hline \multicolumn{11}{|l|}{ Notes: } \\
\hline
\end{tabular}




\begin{tabular}{|c|c|c|c|c|c|c|c|c|c|c|}
\hline \multicolumn{11}{|c|}{1 um NOMINAL FILTER (Bag 1) - Run 12} \\
\hline Water & $\begin{array}{l}\text { Total Vol. } \\
\text { Filtered } \\
\text { (L) }\end{array}$ & $\begin{array}{l}\text { Turbidity } \\
\text { (NTU) }\end{array}$ & \begin{tabular}{|c|}
$\begin{array}{c}\text { Vol. of } \\
\text { Water } \\
\text { Discharged } \\
\text { (L) }\end{array}$ \\
\end{tabular} & $\begin{array}{c}\text { Volume of } \\
\text { Water } \\
(\mathrm{mL})\end{array}$ & Time (sec) & Time $(\mathrm{min})$ & $\begin{array}{c}\text { Flowrate } \\
\text { (L/sec) }\end{array}$ & $\begin{array}{l}\text { Flowrate } \\
\text { ( } \mathrm{mL} / \mathrm{min})\end{array}$ & Ho (inch) & $\mathrm{Hn}$ (inch) \\
\hline \multirow[t]{6}{*}{$\begin{array}{c}\text { Raw } \\
\text { Water }\end{array}$} & 0 & 505 & 0 & 0 & 0 & 0 & \#DIV/O! & 0 & & 16.50 \\
\hline & 2 & 6.23 & 2 & 2000 & 104 & 1.733 & 0.01923 & 1153.85 & 16.50 & 14.00 \\
\hline & 4 & 2.19 & 2 & 2000 & 130 & 2.167 & 0.01538 & 923.08 & 14.00 & 11.25 \\
\hline & 6 & 1.96 & 2 & 2000 & 187 & 3.117 & 0.01070 & 641.71 & 11.25 & 9.00 \\
\hline & 8 & 1.10 & 2 & 2000 & 302 & 5.033 & 0.00662 & 397.35 & 9.00 & 4.75 \\
\hline & 8.625 & 0.87 & 0.625 & 625 & 159 & 2.650 & 0.00393 & 235.85 & 4.75 & 3.00 \\
\hline
\end{tabular}

\section{EXPERIMENT A-2 DATA}

\begin{tabular}{|c|c|c|c|c|c|c|c|c|c|c|}
\hline \multicolumn{11}{|c|}{1 um NOMINAL FILTER (Bag \#5) - Run 1} \\
\hline Water & $\begin{array}{l}\text { Total Vol. } \\
\text { Filtered } \\
\text { (L) }\end{array}$ & $\begin{array}{l}\text { Turbidity } \\
\text { (NTU) }\end{array}$ & \begin{tabular}{|c|}
$\begin{array}{c}\text { Vol. of } \\
\text { Water } \\
\text { Discharged } \\
\text { (L) }\end{array}$ \\
\end{tabular} & $\begin{array}{c}\text { Volume of } \\
\text { Water } \\
(\mathrm{mL})\end{array}$ & Time (sec) & Time (min) & $\begin{array}{c}\text { Flowrate } \\
\text { (L/sec) }\end{array}$ & $\begin{array}{l}\text { Flowrate } \\
(\mathrm{mL} / \mathrm{min})\end{array}$ & Ho (inch) & $\mathrm{Hn}$ (inch) \\
\hline \multirow[t]{6}{*}{$\begin{array}{c}\text { Raw } \\
\text { Water }\end{array}$} & 0 & $\mathrm{~N} / \mathrm{M}$ & 0 & 0 & 0 & 0 & \#DIV/O! & 0 & & 33.00 \\
\hline & 2 & 1.15 & 2 & 2000 & 59 & 0.983 & 0.03390 & 2033.90 & 33.00 & 30.50 \\
\hline & 4 & 0.91 & 2 & 2000 & 68 & 1.133 & 0.02941 & 1764.71 & 30.50 & 28.25 \\
\hline & 6 & 2.30 & 2 & 2000 & 67 & 1.117 & 0.02985 & 1791.04 & 28.25 & 25.50 \\
\hline & 8 & 0.78 & 2 & 2000 & 74 & 1.233 & 0.02703 & 1621.62 & 25.50 & 21.50 \\
\hline & 9 & 0.83 & 1 & 1000 & 45 & 0.750 & 0.02222 & 1333.33 & 21.50 & 19.50 \\
\hline
\end{tabular}

For Runs 2-10, head was measured incorrectly. Head was measured from the outlet port

on the waterbag instead of from the ground.

\begin{tabular}{|c|c|c|c|c|c|c|c|c|c|c|}
\hline \multicolumn{11}{|c|}{1 um NOMINAL FILTER (Bag 5) - Run 2} \\
\hline Water & $\begin{array}{l}\text { Total Vol. } \\
\text { Filtered } \\
\text { (L) }\end{array}$ & $\begin{array}{c}\text { Turbidity } \\
\text { (NTU) }\end{array}$ & \begin{tabular}{|c|}
$\begin{array}{c}\text { Vol. of } \\
\text { Water } \\
\text { Discharged } \\
\text { (L) }\end{array}$ \\
\end{tabular} & $\begin{array}{c}\text { Volume of } \\
\text { Water } \\
(\mathrm{mL})\end{array}$ & Time (sec) & Time $(\min )$ & $\begin{array}{c}\text { Flowrate } \\
\text { (L/sec) }\end{array}$ & $\begin{array}{l}\text { Flowrate } \\
(\mathrm{mL} / \mathrm{min})\end{array}$ & Ho (inch) & Hn (inch) \\
\hline \multirow[t]{6}{*}{$\begin{array}{c}\text { Raw } \\
\text { Water }\end{array}$} & 0 & 431 & 0 & 0 & 0 & 0 & \#DIV/O! & 0 & & 17.00 \\
\hline & 2 & 0.58 & 2 & 2000 & 91 & 1.517 & 0.02198 & 1318.68 & 17.00 & 15.50 \\
\hline & 4 & 0.60 & 2 & 2000 & 78 & 1.300 & 0.02564 & 1538.46 & 15.50 & 13.50 \\
\hline & 6 & 0.53 & 2 & 2000 & 94 & 1.567 & 0.02128 & 1276.60 & 13.50 & 10.50 \\
\hline & 8 & 0.48 & 2 & 2000 & 102 & 1.700 & 0.01961 & 1176.47 & 10.50 & 8.00 \\
\hline & 10.0 & 0.53 & 2 & 2000 & 233 & 3.883 & 0.00858 & 515.02 & 8.00 & 3.00 \\
\hline Notes: & & & & & & & & & & \\
\hline
\end{tabular}




\begin{tabular}{|c|c|c|c|c|c|c|c|c|c|c|}
\hline \multicolumn{11}{|c|}{1 um NOMINAL FILTER (Bag 5) - Run 3} \\
\hline Water & $\begin{array}{l}\text { Total Vol. } \\
\text { Filtered } \\
\text { (L) }\end{array}$ & $\begin{array}{c}\text { Turbidity } \\
\text { (NTU) }\end{array}$ & \begin{tabular}{|c|} 
Vol. of \\
Water \\
Discharged \\
(L) \\
\end{tabular} & $\begin{array}{c}\text { Volume of } \\
\text { Water } \\
(\mathrm{mL})\end{array}$ & Time (sec) & Time (min) & $\begin{array}{c}\text { Flowrate } \\
\text { (L/sec) }\end{array}$ & $\begin{array}{l}\text { Flowrate } \\
(\mathrm{mL} / \mathrm{min})\end{array}$ & Ho (inch) & $\mathrm{Hn}$ (inch) \\
\hline \multirow[t]{6}{*}{$\begin{array}{c}\text { Raw } \\
\text { Water }\end{array}$} & 0 & 460 & 0 & 0 & 0 & 0 & \#DIV/O! & 0 & & 17.00 \\
\hline & 2 & 0.37 & 2 & 2000 & 67 & 1.117 & 0.02985 & 1791.04 & 17.00 & 15.50 \\
\hline & 4 & 0.44 & 2 & 2000 & 87 & 1.450 & 0.02299 & 1379.31 & 15.50 & 12.75 \\
\hline & 6 & 0.42 & 2 & 2000 & 97 & 1.617 & 0.02062 & 1237.11 & 12.75 & 10.00 \\
\hline & 8 & 0.94 & 2 & 2000 & 120 & 2.000 & 0.01667 & 1000.00 & 10.00 & 6.75 \\
\hline & 9.0 & 0.33 & 1 & 1000 & 95 & 1.583 & 0.01053 & 631.58 & 6.75 & 3.75 \\
\hline Notes: & & & & & & & & & & \\
\hline
\end{tabular}

\begin{tabular}{|c|c|c|c|c|c|c|c|c|c|c|}
\hline \multicolumn{11}{|c|}{1 um NOMINAL FILTER (Bag 5) - Run 4} \\
\hline Water & $\begin{array}{l}\text { Total Vol. } \\
\text { Filtered } \\
\text { (L) }\end{array}$ & $\begin{array}{l}\text { Turbidity } \\
\text { (NTU) }\end{array}$ & \begin{tabular}{|c|} 
Vol. of \\
Water \\
Discharged \\
(L)
\end{tabular} & $\begin{array}{c}\text { Volume of } \\
\text { Water } \\
(\mathrm{mL})\end{array}$ & Time (sec) & Time $(\mathrm{min})$ & $\begin{array}{c}\text { Flowrate } \\
\text { (L/sec) }\end{array}$ & $\begin{array}{l}\text { Flowrate } \\
(\mathrm{mL} / \mathrm{min})\end{array}$ & Ho (inch) & $\mathrm{Hn}$ (inch) \\
\hline \multirow[t]{6}{*}{$\begin{array}{c}\text { Raw } \\
\text { Water }\end{array}$} & 0 & 329 & 0 & 0 & 0 & 0 & \#DIV/0! & 0 & & 17.75 \\
\hline & 2 & 0.47 & 2 & 2000 & 75 & 1.250 & 0.02667 & 1600.00 & 17.75 & 16.00 \\
\hline & 4 & 0.29 & 2 & 2000 & 91 & 1.517 & 0.02198 & 1318.68 & 16.00 & 13.50 \\
\hline & 6 & 0.26 & 2 & 2000 & 102 & 1.700 & 0.01961 & 1176.47 & 13.50 & 11.25 \\
\hline & 8 & 2.57 & 2 & 2000 & 124 & 2.067 & 0.01613 & 967.74 & 11.25 & 8.00 \\
\hline & 10.0 & 0.33 & 2 & 2000 & 208 & 3.467 & 0.00962 & 576.92 & 8.00 & 2.75 \\
\hline Notes: & & & & & & & & & & \\
\hline
\end{tabular}

\begin{tabular}{|c|c|c|c|c|r|r|r|r|r|r|}
\hline $\mathbf{1}$ um NOMINAL FILTER (Bag 5) - Run 5 & $\begin{array}{c}\text { Vol. of } \\
\text { Water } \\
\text { Water }\end{array}$ & $\begin{array}{c}\text { Total Vol. } \\
\text { Filtered } \\
\text { (L) }\end{array}$ & $\begin{array}{c}\text { Turbidity } \\
\text { (NTU) }\end{array}$ & $\begin{array}{c}\text { Volume of } \\
\text { Water } \\
\text { (L) }\end{array}$ & Time (sec) & Time (min) & $\begin{array}{c}\text { Flowrate } \\
\text { (L/sec) }\end{array}$ & $\begin{array}{c}\text { Flowrate } \\
\text { (mL/min) }\end{array}$ & Ho (inch) & Hn (inch) \\
\hline $\begin{array}{c}\text { Raw } \\
\text { Water }\end{array}$ & 0 & 32.1 & 0 & 0 & 0 & 0 & \#DIV/0! & 0 & & 17.50 \\
\hline & 2 & 1.29 & 2 & 2000 & 102 & 1.700 & 0.01961 & 1176.47 & 17.50 & 15.75 \\
\hline & 4 & 1.26 & 2 & 2000 & 123 & 2.050 & 0.01626 & 975.61 & 15.75 & 13.00 \\
\hline & 6 & 0.42 & 2 & 2000 & 163 & 2.717 & 0.01227 & 736.20 & 13.00 & 10.75 \\
\hline & 8 & 0.39 & 2 & 2000 & 221 & 3.683 & 0.00905 & 542.99 & 10.75 & 8.00 \\
\hline & 9.4 & 0.41 & 1.4 & 1400 & 194 & 3.233 & 0.00722 & 432.99 & 8.00 & 4.75 \\
\hline Notes:
\end{tabular}




\begin{tabular}{|c|c|c|c|c|c|c|c|c|c|c|}
\hline \multicolumn{11}{|c|}{1 um NOMINAL FILTER (Bag 5) - Run 6} \\
\hline Water & $\begin{array}{l}\text { Total Vol. } \\
\text { Filtered } \\
\text { (L) }\end{array}$ & $\begin{array}{c}\text { Turbidity } \\
\text { (NTU) }\end{array}$ & \begin{tabular}{|c|} 
Vol. of \\
Water \\
Discharged \\
(L) \\
\end{tabular} & $\begin{array}{c}\text { Volume of } \\
\text { Water } \\
(\mathrm{mL})\end{array}$ & Time (sec) & Time (min) & $\begin{array}{c}\text { Flowrate } \\
\text { (L/sec) }\end{array}$ & $\begin{array}{l}\text { Flowrate } \\
\text { (mL/min) }\end{array}$ & Ho (inch) & $\mathrm{Hn}$ (inch) \\
\hline \multirow[t]{6}{*}{$\begin{array}{c}\text { Raw } \\
\text { Water }\end{array}$} & 0 & 27.9 & 0 & 0 & 0 & 0 & \#DIV/O! & 0 & & 16.00 \\
\hline & 2 & 0.34 & 2 & 2000 & 149 & 2.483 & 0.01342 & 805.37 & 16.00 & 14.00 \\
\hline & 4 & 0.38 & 2 & 2000 & 167 & 2.783 & 0.01198 & 718.56 & 14.00 & 11.25 \\
\hline & 6 & 0.36 & 2 & 2000 & 185 & 3.083 & 0.01081 & 648.65 & 11.25 & 8.75 \\
\hline & 8 & 0.31 & 2 & 2000 & 235 & 3.917 & 0.00851 & 510.64 & 8.75 & 5.25 \\
\hline & 9.0 & 0.33 & 1 & 1000 & 207 & 3.450 & 0.00483 & 289.86 & 5.25 & 3.00 \\
\hline Notes: & & & & & & & & & & \\
\hline
\end{tabular}

\begin{tabular}{|c|c|c|c|c|r|r|r|r|r|r|}
\hline 1 um NOMINAL FILTER (Bag 5) - Run 7 \\
\hline Water & $\begin{array}{c}\text { Total Vol. } \\
\text { Filtered } \\
\text { (L) }\end{array}$ & $\begin{array}{c}\text { Turbidity } \\
\text { (NTU) }\end{array}$ & $\begin{array}{c}\text { Vol. of } \\
\text { Water } \\
\text { Discharged } \\
\text { (L) }\end{array}$ & $\begin{array}{c}\text { Volume of } \\
\text { Water } \\
\text { (mL) }\end{array}$ & Time (sec) & Time (min) & $\begin{array}{c}\text { Flowrate } \\
\text { (L/sec) }\end{array}$ & $\begin{array}{c}\text { Flowrate } \\
\text { (mL/min) }\end{array}$ & Ho (inch) & Hn (inch) \\
\hline $\begin{array}{c}\text { Raw } \\
\text { Water }\end{array}$ & 0 & 23.3 & 0 & 0 & 0 & 0 & \#DIV/0! & 0 & & 16.00 \\
\hline & 2 & 1.32 & 2 & 2000 & 120 & 2.000 & 0.01667 & 1000.00 & 16.00 & 13.50 \\
\hline & 4 & 0.44 & 2 & 2000 & 144 & 2.400 & 0.01389 & 833.33 & 13.50 & 10.50 \\
\hline & 6 & 0.52 & 2 & 2000 & 163 & 2.717 & 0.01227 & 736.20 & 10.50 & 8.00 \\
\hline & 8 & 0.44 & 2 & 2000 & 217 & 3.617 & 0.00922 & 553.00 & 8.00 & 4.00 \\
\hline & 8.6 & 0.38 & 0.55 & 550 & 86 & 1.433 & 0.00640 & 383.72 & 4.00 & 2.50 \\
\hline Notes:
\end{tabular}

\begin{tabular}{|c|c|c|c|c|c|c|c|c|c|c|}
\hline \multicolumn{11}{|c|}{1 um NOMINAL FILTER (Bag 5) - Run 8} \\
\hline Water & $\begin{array}{l}\text { Total Vol. } \\
\text { Filtered } \\
\text { (L) }\end{array}$ & $\begin{array}{l}\text { Turbidity } \\
\text { (NTU) }\end{array}$ & \begin{tabular}{|c|}
$\begin{array}{c}\text { Vol. of } \\
\text { Water } \\
\text { Discharged } \\
\text { (L) }\end{array}$ \\
\end{tabular} & $\begin{array}{c}\text { Volume of } \\
\text { Water } \\
(\mathrm{mL})\end{array}$ & Time (sec) & Time $(\mathrm{min})$ & $\begin{array}{c}\text { Flowrate } \\
\text { (L/sec) }\end{array}$ & $\begin{array}{l}\text { Flowrate } \\
(\mathrm{mL} / \mathrm{min})\end{array}$ & Ho (inch) & $\mathrm{Hn}$ (inch) \\
\hline \multirow[t]{6}{*}{$\begin{array}{c}\text { Raw } \\
\text { Water }\end{array}$} & 0 & & & 0 & 0 & 0 & \#DIV/O! & 0 & & 15.75 \\
\hline & 2 & 0.36 & 2 & 2000 & 66 & 1.100 & 0.03030 & 1818.18 & 15.75 & 13.75 \\
\hline & 4 & 0.30 & 2 & 2000 & 80 & 1.333 & 0.02500 & 1500.00 & 13.75 & 11.50 \\
\hline & 6 & 0.36 & 2 & 2000 & 99 & 1.650 & 0.02020 & 1212.12 & 11.50 & 9.25 \\
\hline & 8 & 0.32 & 2 & 2000 & 132 & 2.200 & 0.01515 & 909.09 & 9.25 & 5.50 \\
\hline & 9 & 0.25 & 1 & 1000 & 95 & 1.583 & 0.01053 & 631.58 & 5.50 & 3.25 \\
\hline
\end{tabular}




\begin{tabular}{|c|c|c|c|c|r|r|r|r|r|r|}
\hline $\mathbf{1}$ um NOMINAL FILTER (Bag 5) - Run 9 & $\begin{array}{c}\text { Vol. of } \\
\text { Water } \\
\text { Water }\end{array}$ & $\begin{array}{c}\text { Total Vol. } \\
\text { Filtered } \\
\text { (L) }\end{array}$ & $\begin{array}{c}\text { Turbidity } \\
\text { (NTU) }\end{array}$ & $\begin{array}{c}\text { Volume of } \\
\text { Water } \\
\text { (L) }\end{array}$ & Time (sec) & Time (min) & $\begin{array}{c}\text { Flowrate } \\
\text { (L/sec) }\end{array}$ & $\begin{array}{c}\text { Flowrate } \\
\text { (mL/min) }\end{array}$ & Ho (inch) & Hn (inch) \\
\hline $\begin{array}{c}\text { Raw } \\
\text { Water }\end{array}$ & 0 & & 0 & 0 & 0 & 0 & \#DIV/0! & 0 & & 17.00 \\
\hline & 2 & 0.37 & 2 & 2000 & 126 & 2.100 & 0.01587 & 952.38 & 17.00 & 15.00 \\
\hline & 4 & 0.32 & 2 & 2000 & 122 & 2.033 & 0.01639 & 983.61 & 15.00 & 12.00 \\
\hline & 6 & 0.47 & 2 & 2000 & 195 & 3.250 & 0.01026 & 615.38 & 12.00 & 9.50 \\
\hline & 8 & 0.26 & 2 & 2000 & 277 & 4.617 & 0.00722 & 433.21 & 9.50 & 6.50 \\
\hline & 9 & 0.17 & 1 & 1000 & 184 & 3.067 & 0.00543 & 326.09 & 6.50 & 4.50 \\
\hline Notes: & & & & & & & & \\
\hline
\end{tabular}

\section{1 um NOMINAL FILTER (Bag 5) - Run 10}

\begin{tabular}{|c|c|c|c|c|r|r|r|r|r|r|}
\hline Water & $\begin{array}{c}\text { Total Vol. } \\
\text { Filtered } \\
\text { (L) }\end{array}$ & $\begin{array}{c}\text { Turbidity } \\
\text { (NTU) }\end{array}$ & $\begin{array}{c}\text { Vol. of } \\
\text { Water } \\
\text { Discharged } \\
\text { (L) }\end{array}$ & $\begin{array}{c}\text { Volume of } \\
\text { Water } \\
(\mathbf{m L})\end{array}$ & Time (sec) & Time (min) & $\begin{array}{c}\text { Flowrate } \\
\text { (L/sec) }\end{array}$ & $\begin{array}{c}\text { Flowrate } \\
\text { (mL/min) }\end{array}$ & Ho (inch) & Hn (inch) \\
\hline $\begin{array}{c}\text { Raw } \\
\text { Water }\end{array}$ & 0 & & 0 & 0 & 0 & 0 & \#DIV/0! & 0 & & 15.25 \\
\hline & 2 & 0.17 & 2 & 2000 & 251 & 4.183 & 0.00797 & 478.09 & 15.25 & 13.25 \\
\hline & 4 & 0.16 & 2 & 2000 & 313 & 5.217 & 0.00639 & 383.39 & 13.25 & 10.00 \\
\hline & 6 & 0.14 & 2 & 2000 & 349 & 5.817 & 0.00573 & 343.84 & 10.00 & 7.50 \\
\hline & 8 & 0.09 & 2 & 2000 & 521 & 8.683 & 0.00384 & 230.33 & 7.50 & 4.25 \\
\hline & 9 & 0.14 & 1 & 1000 & 380 & 6.333 & 0.00263 & 157.89 & 4.25 & 2.00 \\
\hline Notes: & & & & & & & & & \\
\hline
\end{tabular}

\section{EXPERIMENT A-3}

\begin{tabular}{|c|c|c|c|c|c|c|c|c|c|c|}
\hline \multicolumn{11}{|c|}{500 um NETTING + 1 um NOMINAL FILTER (Bag \#6) - Run 1} \\
\hline Water & $\begin{array}{l}\text { Total Vol. } \\
\text { Filtered } \\
\text { (L) }\end{array}$ & $\begin{array}{c}\text { Turbidity } \\
\text { (NTU) }\end{array}$ & \begin{tabular}{|c|}
$\begin{array}{c}\text { Vol. of } \\
\text { Water } \\
\text { Discharged } \\
\text { (L) }\end{array}$ \\
\end{tabular} & $\begin{array}{c}\text { Volume of } \\
\text { Water } \\
(\mathrm{mL})\end{array}$ & Time (sec) & Time $(\mathrm{min})$ & $\begin{array}{c}\text { Flowrate } \\
\text { (L/sec) }\end{array}$ & $\begin{array}{l}\text { Flowrate } \\
(\mathrm{mL} / \mathrm{min})\end{array}$ & Ho (inch) & $\mathrm{Hn}$ (inch) \\
\hline \multirow[t]{6}{*}{$\begin{array}{c}\text { Raw } \\
\text { Water }\end{array}$} & 0 & $\mathrm{~N} / \mathrm{M}$ & 0 & 0 & 0 & 0 & \#DIV/0! & o & & 34.25 \\
\hline & 2 & 0.97 & 2 & 2000 & 37 & 0.617 & 0.05405 & 3243.24 & 34.25 & 32.25 \\
\hline & 4 & 1.21 & 2 & 2000 & 40 & 0.667 & 0.05000 & 3000.00 & 32.25 & 29.50 \\
\hline & 6 & 0.88 & 2 & 2000 & 45 & 0.750 & 0.04444 & 2666.67 & 29.50 & 26.50 \\
\hline & 8 & 0.91 & 2 & 2000 & 50 & 0.833 & 0.04000 & 2400.00 & 26.50 & 23.00 \\
\hline & 9 & 0.79 & 1.3 & 1300 & 40 & 0.667 & 0.03250 & 1950.00 & 23.00 & 19.00 \\
\hline Notes: & & & & & & & & & & \\
\hline
\end{tabular}

For Runs 2-10, head was measured incorrectly. Head was measured from the outlet port on the waterbag instead of from the ground. 


\begin{tabular}{|c|c|c|c|c|c|c|c|c|c|c|}
\hline \multicolumn{11}{|c|}{500 um NETIING + 1 um NOMINAL FILTER (Bag 6) - Run 2} \\
\hline Water & $\begin{array}{l}\text { Total Vol. } \\
\text { Filtered } \\
\text { (L) }\end{array}$ & $\begin{array}{l}\text { Turbidity } \\
\text { (NTU) }\end{array}$ & \begin{tabular}{|c|} 
Vol. of \\
Water \\
Discharged \\
(L) \\
\end{tabular} & $\begin{array}{c}\text { Volume of } \\
\text { Water } \\
(\mathrm{mL})\end{array}$ & Time $(\mathrm{sec})$ & Time $(\mathrm{min})$ & $\begin{array}{c}\text { Flowrate } \\
\text { (L/sec) }\end{array}$ & $\begin{array}{l}\text { Flowrate } \\
(\mathrm{mL} / \mathrm{min})\end{array}$ & Ho (inch) & Hn (inch) \\
\hline \multirow[t]{6}{*}{$\begin{array}{c}\text { Raw } \\
\text { Water }\end{array}$} & 0 & 431 & 0 & 0 & 0 & 0 & \#DIV/O! & 0 & & 17.25 \\
\hline & 2 & 0.58 & 2 & 2000 & 44 & 0.733 & 0.04545 & 2727.27 & 17.25 & 15.50 \\
\hline & 4 & 1.56 & 2 & 2000 & 46 & 0.767 & 0.04348 & 2608.70 & 15.50 & 13.00 \\
\hline & 6 & 0.59 & 2 & 2000 & 54 & 0.900 & 0.03704 & 2222.22 & 13.00 & 10.25 \\
\hline & 8 & 0.79 & 2 & 2000 & 68 & 1.133 & 0.02941 & 1764.71 & 10.25 & 7.00 \\
\hline & 9.0 & 0.71 & 1 & 1000 & 46 & 0.767 & 0.02174 & 1304.35 & 7.00 & 4.25 \\
\hline
\end{tabular}

\section{0 um NETIING + 1 um NOMINAL FILTER (Bag 6) - Run 3}

\begin{tabular}{|c|c|c|c|c|c|c|c|c|c|c|}
\hline Water & $\begin{array}{l}\text { Total Vol. } \\
\text { Filtered } \\
\text { (L) }\end{array}$ & $\begin{array}{l}\text { Turbidity } \\
\text { (NTU) }\end{array}$ & \begin{tabular}{|c|}
$\begin{array}{c}\text { Vol. of } \\
\text { Water } \\
\text { Discharged } \\
\text { (L) }\end{array}$ \\
\end{tabular} & $\begin{array}{c}\text { Volume of } \\
\text { Water } \\
(\mathrm{mL})\end{array}$ & Time (sec) & Time $(\min )$ & $\begin{array}{c}\text { Flowrate } \\
\text { (L/sec) }\end{array}$ & $\begin{array}{l}\text { Flowrate } \\
\text { ( } \mathrm{mL} / \mathrm{min} \text { ) }\end{array}$ & Ho (inch) & $\mathrm{Hn}$ (inch) \\
\hline \multirow[t]{6}{*}{$\begin{array}{c}\text { Raw } \\
\text { Water }\end{array}$} & 0 & 337 & 0 & 0 & 0 & 이 & \#DIV/O! & o & & 16.50 \\
\hline & 2 & 0.95 & 2 & 2000 & 45 & 0.750 & 0.04444 & 2666.67 & 16.50 & 14.00 \\
\hline & 4 & 1.46 & 2 & 2000 & 53 & 0.883 & 0.03774 & 2264.15 & 14.00 & 11.00 \\
\hline & 6 & 1.02 & 2 & 2000 & 59 & 0.983 & 0.03390 & 2033.90 & 11.00 & 8.50 \\
\hline & 8 & 1.03 & 2 & 2000 & 74 & 1.233 & 0.02703 & 1621.62 & 8.50 & 5.50 \\
\hline & 9.4 & 1.04 & 1.4 & 1400 & 97 & 1.617 & 0.01443 & 865.98 & 5.50 & 1.50 \\
\hline
\end{tabular}

\begin{tabular}{|c|c|c|c|c|c|c|c|c|c|c|}
\hline \multicolumn{11}{|c|}{500 um NETIING + 1 um NOMINAL FILTER (Bag 6) - Run 4} \\
\hline Water & $\begin{array}{l}\text { Total Vol. } \\
\text { Filtered } \\
\text { (L) }\end{array}$ & $\begin{array}{c}\text { Turbidity } \\
\text { (NTU) }\end{array}$ & \begin{tabular}{|c|} 
Vol. of \\
Water \\
Discharged \\
(L)
\end{tabular} & $\begin{array}{c}\text { Volume of } \\
\text { Water } \\
(\mathrm{mL})\end{array}$ & Time $(\mathrm{sec})$ & Time $(\min )$ & $\begin{array}{c}\text { Flowrate } \\
\text { (L/sec) }\end{array}$ & $\begin{array}{c}\text { Flowrate } \\
(\mathrm{mL} / \mathrm{min})\end{array}$ & Ho (inch) & $\mathrm{Hn}$ (inch) \\
\hline \multirow[t]{6}{*}{$\begin{array}{c}\text { Raw } \\
\text { Water }\end{array}$} & 0 & 412 & 0 & 0 & 0 & 0 & \#DIV/O! & 0 & & 16.00 \\
\hline & 2 & 0.74 & 2 & 2000 & 45 & 0.750 & 0.04444 & 2666.67 & 16.00 & 13.50 \\
\hline & 4 & 0.45 & 2 & 2000 & 52 & 0.867 & 0.03846 & 2307.69 & 13.50 & 10.50 \\
\hline & 6 & 0.40 & 2 & 2000 & 62 & 1.033 & 0.03226 & 1935.48 & 10.50 & 8.00 \\
\hline & 8 & 0.51 & 2 & 2000 & 80 & 1.333 & 0.02500 & 1500.00 & 8.00 & 4.75 \\
\hline & 10.0 & 0.47 & 2 & 2000 & 80 & 1.333 & 0.02500 & 1500.00 & 4.75 & 1.50 \\
\hline
\end{tabular}




\begin{tabular}{|c|c|c|c|c|c|c|c|c|c|c|}
\hline \multicolumn{11}{|c|}{500 um NETIING + 1 um NOMINAL FILTER (Bag 6) - Run 5} \\
\hline Water & $\begin{array}{l}\text { Total Vol. } \\
\text { Filtered } \\
\text { (L) }\end{array}$ & $\begin{array}{c}\text { Turbidity } \\
\text { (NTU) }\end{array}$ & \begin{tabular}{|c|} 
Vol. of \\
Water \\
Discharged \\
(L)
\end{tabular} & $\begin{array}{c}\text { Volume of } \\
\text { Water } \\
(\mathrm{mL})\end{array}$ & Time (sec) & Time (min) & $\begin{array}{c}\text { Flowrate } \\
\text { (L/sec) }\end{array}$ & $\begin{array}{l}\text { Flowrate } \\
(\mathrm{mL} / \mathrm{min})\end{array}$ & Ho (inch) & Hn (inch) \\
\hline \multirow[t]{6}{*}{$\begin{array}{c}\text { Raw } \\
\text { Water }\end{array}$} & 0 & 32.1 & 0 & 0 & 0 & 0 & \#DIV/0! & 0 & & 17.00 \\
\hline & 2 & 0.43 & 2 & 2000 & 49 & 0.817 & 0.04082 & 2448.98 & 17.00 & 16.00 \\
\hline & 4 & 0.51 & 2 & 2000 & 53 & 0.883 & 0.03774 & 2264.15 & 16.00 & 13.25 \\
\hline & 6 & 0.42 & 2 & 2000 & 65 & 1.083 & 0.03077 & 1846.15 & 13.25 & 10.00 \\
\hline & 8 & 0.42 & 2 & 2000 & 89 & 1.483 & 0.02247 & 1348.31 & 10.00 & 6.75 \\
\hline & 9.4 & 0.45 & 1.4 & 1400 & 169 & 2.817 & 0.00828 & 497.04 & 6.75 & 3.50 \\
\hline
\end{tabular}

\begin{tabular}{|c|c|c|c|c|c|c|c|c|c|c|}
\hline \multicolumn{11}{|c|}{500 um NETIING + 1 um NOMINAL FILTER (Bag 6) - Run 6} \\
\hline Water & $\begin{array}{l}\text { Total Vol. } \\
\text { Filtered } \\
\text { (L) }\end{array}$ & $\begin{array}{c}\text { Turbidity } \\
\text { (NTU) }\end{array}$ & \begin{tabular}{|c|}
$\begin{array}{c}\text { Vol. of } \\
\text { Water } \\
\text { Discharged } \\
\text { (L) }\end{array}$ \\
\end{tabular} & $\begin{array}{c}\text { Volume of } \\
\text { Water } \\
(\mathrm{mL})\end{array}$ & Time (sec) & Time $(\min )$ & $\begin{array}{c}\text { Flowrate } \\
\text { (L/sec) }\end{array}$ & $\begin{array}{l}\text { Flowrate } \\
(\mathrm{mL} / \mathrm{min})\end{array}$ & Ho (inch) & $\mathrm{Hn}$ (inch) \\
\hline \multirow[t]{6}{*}{$\begin{array}{c}\text { Raw } \\
\text { Water }\end{array}$} & 0 & 27.9 & 0 & 0 & 0 & 0 & \#DIV/0! & 0 & & 15.75 \\
\hline & 2 & 0.32 & 2 & 2000 & 48 & 0.800 & 0.04167 & 2500.00 & 15.75 & 14.00 \\
\hline & 4 & 0.35 & 2 & 2000 & 56 & 0.933 & 0.03571 & 2142.86 & 14.00 & 10.75 \\
\hline & 6 & 0.37 & 2 & 2000 & 65 & 1.083 & 0.03077 & 1846.15 & 10.75 & 8.25 \\
\hline & 8 & 0.38 & 2 & 2000 & 86 & 1.433 & 0.02326 & 1395.35 & 8.25 & 4.50 \\
\hline & 8.9 & 0.40 & 0.85 & 850 & 82 & 1.367 & 0.01037 & 621.95 & 4.50 & 1.75 \\
\hline
\end{tabular}

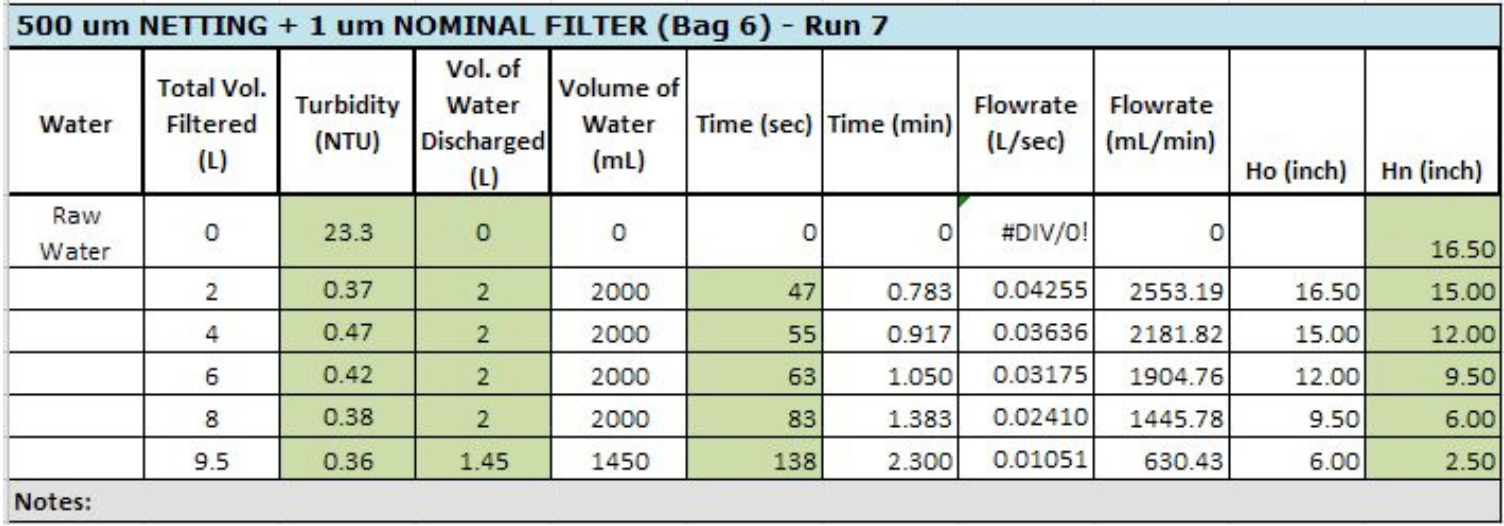




\begin{tabular}{|c|c|c|c|c|c|c|c|c|c|c|}
\hline \multicolumn{11}{|c|}{500 um NETIING + 1 um NOMINAL FILTER (Bag 6) - Run 8} \\
\hline Water & $\begin{array}{l}\text { Total Vol. } \\
\text { Filtered } \\
\text { (L) }\end{array}$ & $\begin{array}{l}\text { Turbidity } \\
\text { (NTU) }\end{array}$ & \begin{tabular}{|c|} 
Vol. of \\
Water \\
Discharged \\
(L)
\end{tabular} & $\begin{array}{c}\text { Volume of } \\
\text { Water } \\
(\mathrm{mL})\end{array}$ & Time $(\mathrm{sec})$ & Time $(\min )$ & $\begin{array}{c}\text { Flowrate } \\
\text { (L/sec) }\end{array}$ & $\begin{array}{l}\text { Flowrate } \\
(\mathrm{mL} / \mathrm{min})\end{array}$ & Ho (inch) & Hn (inch) \\
\hline \multirow[t]{6}{*}{$\begin{array}{c}\text { Raw } \\
\text { Water }\end{array}$} & 0 & & 0 & 0 & 0 & 0 & \#DIV/O! & 0 & & 16.25 \\
\hline & 2 & 0.63 & 2 & 2000 & 44 & 0.733 & 0.04545 & 2727.27 & 16.25 & 14.25 \\
\hline & 4 & 0.58 & 2 & 2000 & 50 & 0.833 & 0.04000 & 2400.00 & 14.25 & 12.00 \\
\hline & 6 & 0.44 & 2 & 2000 & 59 & 0.983 & 0.03390 & 2033.90 & 12.00 & 9.50 \\
\hline & 8 & 0.69 & 2 & 2000 & 74 & 1.233 & 0.02703 & 1621.62 & 9.50 & 5.50 \\
\hline & 9 & 0.46 & 1 & 1000 & 50 & 0.833 & 0.02000 & 1200.00 & 5.50 & 3.50 \\
\hline
\end{tabular}

\begin{tabular}{|c|c|c|c|c|c|c|c|c|c|c|}
\hline \multicolumn{11}{|c|}{500 um NETTING + 1 um NOMINAL FILTER (Bag 6) - Run 9} \\
\hline Water & $\begin{array}{l}\text { Total Vol. } \\
\text { Filtered } \\
\text { (L) }\end{array}$ & $\begin{array}{l}\text { Turbidity } \\
\text { (NTU) }\end{array}$ & \begin{tabular}{|c|} 
Vol. of \\
Water \\
Discharged \\
(L)
\end{tabular} & $\begin{array}{c}\text { Volume of } \\
\text { Water } \\
(\mathrm{mL})\end{array}$ & Time $(\mathrm{sec})$ & Time (min) & $\begin{array}{c}\text { Flowrate } \\
\text { (L/sec) }\end{array}$ & $\begin{array}{l}\text { Flowrate } \\
(\mathrm{mL} / \mathrm{min})\end{array}$ & Ho (inch) & $\mathrm{Hn}$ (inch) \\
\hline \multirow[t]{6}{*}{$\begin{array}{c}\text { Raw } \\
\text { Water }\end{array}$} & 0 & & 0 & 0 & 0 & 0 & \#DIV/0! & 0 & & 16.00 \\
\hline & 2 & 0.49 & 2 & 2000 & 47 & 0.783 & 0.04255 & 2553.19 & 16.00 & 14.00 \\
\hline & 4 & 0.62 & 2 & 2000 & 53 & 0.883 & 0.03774 & 2264.15 & 14.00 & 11.50 \\
\hline & 6 & 0.39 & 2 & 2000 & 62 & 1.033 & 0.03226 & 1935.48 & 11.50 & 9.50 \\
\hline & 8 & 0.53 & 2 & 2000 & 78 & 1.300 & 0.02564 & 1538.46 & 9.50 & 5.00 \\
\hline & 9 & 0.42 & 1 & 1000 & 53 & 0.883 & 0.01887 & 1132.08 & 5.00 & 2.50 \\
\hline
\end{tabular}

\begin{tabular}{|c|c|c|r|r|r|r|r|r|r|r|}
\hline S00 um NOMINAL + 1 um NOMINAL FILTER (Bag 6) - Run 10 \\
\hline Water & $\begin{array}{c}\text { Total Vol. } \\
\text { Filtered } \\
\text { (L) }\end{array}$ & $\begin{array}{c}\text { Turbidity } \\
\text { (NTU) }\end{array}$ & $\begin{array}{c}\text { Vol. of } \\
\text { Water } \\
\text { Discharged } \\
\text { (L) }\end{array}$ & $\begin{array}{c}\text { Volume of } \\
\text { Water } \\
\text { (mL) }\end{array}$ & Time (sec) & Time (min) & $\begin{array}{c}\text { Flowrate } \\
\text { (L/sec) }\end{array}$ & $\begin{array}{c}\text { Flowrate } \\
\text { (mL/min) }\end{array}$ & Ho (inch) & Hn (inch) \\
\hline $\begin{array}{c}\text { Raw } \\
\text { Water }\end{array}$ & 0 & & 0 & 0 & 0 & 0 & \#DIV/0! & 0 & & 16.75 \\
\hline & 2 & 0.74 & 2 & 2000 & 48 & 0.800 & 0.04167 & 2500.00 & 16.75 & 14.50 \\
\hline & 4 & 0.45 & 2 & 2000 & 56 & 0.933 & 0.03571 & 2142.86 & 14.50 & 12.00 \\
\hline & 6 & 0.40 & 2 & 2000 & 65 & 1.083 & 0.03077 & 1846.15 & 12.00 & 9.25 \\
\hline & 8 & 0.37 & 2 & 2000 & 83 & 1.383 & 0.02410 & 1445.78 & 9.25 & 6.00 \\
\hline & 9 & 0.35 & 1 & 1000 & 59 & 0.983 & 0.01695 & 1016.95 & 6.00 & 4.00 \\
\hline & 10 & 0.34 & 1 & 1000 & 104 & 1.733 & 0.00962 & 576.92 & 6.00 & 1.75 \\
\hline Notes: & & & & & & & & & \\
\hline
\end{tabular}


500 um NETIING + 1 um NOMINAL FILTER (Bag 6) - Run 11

\begin{tabular}{|c|c|c|c|c|r|r|r|r|r|r|}
\hline Water & $\begin{array}{c}\text { Total Vol. } \\
\text { Filtered } \\
\text { (L) }\end{array}$ & $\begin{array}{c}\text { Turbidity } \\
\text { (NTU) }\end{array}$ & $\begin{array}{c}\text { Vol. of } \\
\text { Water } \\
\text { Discharged } \\
\text { (L) }\end{array}$ & $\begin{array}{c}\text { Volume of } \\
\text { Water } \\
\text { (mL) }\end{array}$ & Time (sec) & Time (min) & $\begin{array}{c}\text { Flowrate } \\
\text { (L/sec) }\end{array}$ & $\begin{array}{c}\text { Flowrate } \\
\text { (mL/min) }\end{array}$ & Ho (inch) & Hn (inch) \\
\hline $\begin{array}{c}\text { Raw } \\
\text { Water }\end{array}$ & 0 & 416 & 0 & 0 & 0 & 0 & \#DIV/0! & 0 & & 16.50 \\
\hline & 2 & 1.05 & 2 & 2000 & 62 & 1.033 & 0.03226 & 1935.48 & 16.50 & 14.00 \\
\hline & 4 & 0.43 & 2 & 2000 & 80 & 1.333 & 0.02500 & 1500.00 & 14.00 & 12.00 \\
\hline & 6 & 0.41 & 2 & 2000 & 85 & 1.417 & 0.02353 & 1411.76 & 12.00 & 9.25 \\
\hline & 8 & 0.40 & 2 & 2000 & 118 & 1.967 & 0.01695 & 1016.95 & 9.25 & 5.00 \\
\hline & 8.7 & 0.43 & 0.7 & 700 & 75 & 1.250 & 0.00933 & 560.00 & 5.00 & 3.00 \\
\hline Notes: & & & & & & & & & &
\end{tabular}

\section{0 um NETTING + 1 um NOMINAL FILTER (Bag 6) - Run 12}

\begin{tabular}{|c|c|c|c|c|c|c|c|c|c|c|}
\hline Water & $\begin{array}{l}\text { Total Vol. } \\
\text { Filtered } \\
\text { (L) }\end{array}$ & $\begin{array}{l}\text { Turbidity } \\
\text { (NTU) }\end{array}$ & \begin{tabular}{|c|} 
Vol. of \\
Water \\
Discharged \\
(L)
\end{tabular} & $\begin{array}{c}\text { Volume of } \\
\text { Water } \\
(\mathrm{mL})\end{array}$ & Time (sec) & Time (min) & $\begin{array}{c}\text { Flowrate } \\
\text { (L/sec) }\end{array}$ & $\begin{array}{l}\text { Flowrate } \\
(\mathrm{mL} / \mathrm{min})\end{array}$ & Ho (inch) & $\mathrm{Hn}$ (inch) \\
\hline \multirow[t]{6}{*}{$\begin{array}{c}\text { Raw } \\
\text { Water }\end{array}$} & 0 & 411 & 0 & 0 & 0 & 0 & \#DIV/O! & 0 & & 17.00 \\
\hline & 2.1 & 2.28 & 2 & 2100 & 74 & 1.233 & 0.02838 & 1702.70 & 17.00 & 15.00 \\
\hline & 4.1 & 1.95 & 2 & 2000 & 83 & 1.383 & 0.02410 & 1445.78 & 15.00 & 12.00 \\
\hline & 6.1 & 0.75 & 2 & 2000 & 98 & 1.633 & 0.02041 & 1224.49 & 12.00 & 9.50 \\
\hline & 8.1 & 0.86 & 2 & 2000 & 125 & 2.083 & 0.01600 & 960.00 & 9.50 & 6.50 \\
\hline & 9 & 0.89 & 1 & 1000 & 120 & 2.000 & 0.00833 & 500.00 & 6.50 & 3.00 \\
\hline
\end{tabular}




\section{EXPERIMENT B-1}

\begin{tabular}{|c|c|c|c|c|c|c|c|c|c|c|}
\hline \multicolumn{11}{|c|}{ EXTERNAL FILTER (Bag 2) - Run 1} \\
\hline Water & $\begin{array}{l}\text { Total Vol. } \\
\text { Filtered } \\
\text { (L) }\end{array}$ & $\begin{array}{l}\text { Turbidity } \\
\text { (NTU) }\end{array}$ & \begin{tabular}{|c|}
$\begin{array}{c}\text { Vol. of } \\
\text { Water } \\
\text { Discharged } \\
\text { (L) }\end{array}$ \\
\end{tabular} & $\begin{array}{c}\begin{array}{c}\text { Volume of } \\
\text { Water } \\
(\mathrm{mL})\end{array} \\
\end{array}$ & Time $(\mathrm{sec})$ & Time $(\min )$ & $\begin{array}{c}\text { Flowrate } \\
\text { (L/sec) }\end{array}$ & $\begin{array}{l}\text { Flowrate } \\
(\mathrm{mL} / \mathrm{min})\end{array}$ & Ho (inch) & Hn (inch) \\
\hline \multirow[t]{19}{*}{$\begin{array}{c}\text { Raw } \\
\text { Water }\end{array}$} & 0 & & 0 & 0 & o & 0 & \#DIV/O! & 0 & & 35.50 \\
\hline & 0.1 & & 0.1 & 100 & 3.7 & 0.062 & 0.02703 & 1621.62 & 35.50 & \\
\hline & 0.2 & & 0.1 & 100 & 2.3 & 0.038 & 0.04348 & 2608.70 & & \\
\hline & 0.3 & & 0.1 & 100 & 3 & 0.050 & 0.03333 & 2000.00 & & \\
\hline & 0.4 & & 0.1 & 100 & 2 & 0.033 & 0.05000 & 3000.00 & & \\
\hline & 0.5 & & 0.1 & 100 & 4 & 0.067 & 0.02500 & 1500.00 & & \\
\hline & 0.6 & & 0.1 & 100 & 3 & 0.050 & 0.03333 & 2000.00 & & \\
\hline & 0.7 & & 0.1 & 100 & 2.5 & 0.042 & 0.04000 & 2400.00 & & \\
\hline & 0.8 & & 0.1 & 100 & 3.5 & 0.058 & 0.02857 & 1714.29 & & \\
\hline & 0.9 & & 0.1 & 100 & 2 & 0.033 & 0.05000 & 3000.00 & & \\
\hline & 1.65 & 1.62 & 0.75 & 750 & 30 & 0.500 & 0.02500 & 1500.00 & & 33.50 \\
\hline & 2.9 & 1.14 & 1.25 & 1250 & 36.3 & 0.605 & 0.03444 & 2066.12 & 33.50 & 31.50 \\
\hline & 4 & 1.27 & 1.1 & 1100 & 31 & 0.517 & 0.03548 & 2129.03 & 31.50 & 29.50 \\
\hline & 5 & 1.42 & 1 & 1000 & 25.3 & 0.422 & 0.03953 & 2371.54 & 29.50 & 28.50 \\
\hline & 6 & 1.49 & 1 & 1000 & 26 & 0.433 & 0.03846 & 2307.69 & 28.50 & 27.00 \\
\hline & 7 & 1.38 & 1 & 1000 & 27.8 & 0.463 & 0.03597 & 2158.27 & 27.00 & 25.50 \\
\hline & 8 & 1.21 & 1 & 1000 & 28.6 & 0.477 & 0.03497 & 2097.90 & 25.50 & 23.50 \\
\hline & 9 & 1.20 & 1 & 1000 & 31 & 0.517 & 0.03226 & 1935.48 & 23.50 & 21.00 \\
\hline & 9.7 & 1.48 & 0.7 & 700 & 37.3 & 0.622 & 0.01877 & 1126.01 & 21.00 & 20.50 \\
\hline
\end{tabular}

\begin{tabular}{|c|c|c|c|c|c|c|c|c|c|c|}
\hline \multicolumn{11}{|c|}{ EXTERNAL FILTER (Bag 2) - Run 2} \\
\hline Water & $\begin{array}{c}\text { Total Vol. } \\
\text { Filtered } \\
\text { (L) }\end{array}$ & $\begin{array}{l}\text { Turbidity } \\
\text { (NTU) }\end{array}$ & 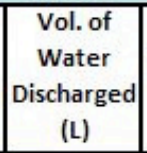 & $\begin{array}{c}\begin{array}{c}\text { Volume of } \\
\text { Water } \\
(\mathrm{mL})\end{array} \\
\end{array}$ & Time $(\mathrm{sec})$ & Time (min) & $\begin{array}{c}\text { Flowrate } \\
\text { (L/sec) }\end{array}$ & $\begin{array}{l}\text { Flowrate } \\
(\mathrm{mL} / \mathrm{min})\end{array}$ & Ho (inch) & $\mathrm{Hn}$ (inch) \\
\hline \multirow[t]{11}{*}{$\begin{array}{c}\text { Raw } \\
\text { Water }\end{array}$} & 0 & & 0 & 0 & 0 & 0 & \#DIV/O! & 0 & & $\mathrm{~N} / \mathrm{M}$ \\
\hline & 1 & & 1 & 1000 & 26 & 0.432 & 0.03860 & 2315.71 & & $\mathrm{~N} / \mathrm{M}$ \\
\hline & 2 & & 1 & 1000 & 24 & 0.400 & 0.04167 & 2500.00 & & $\mathrm{~N} / \mathrm{M}$ \\
\hline & 3 & & 1 & 1000 & 16 & 0.267 & 0.06250 & 3750.00 & & $\mathrm{~N} / \mathrm{M}$ \\
\hline & 4 & & 1 & 1000 & 36 & 0.600 & 0.02778 & 1666.67 & & $\mathrm{~N} / \mathrm{M}$ \\
\hline & 5 & & 1 & 1000 & 27 & 0.450 & 0.03704 & 2222.22 & & $\mathrm{~N} / \mathrm{M}$ \\
\hline & 6 & & 1 & 1000 & 27 & 0.450 & 0.03704 & 2222.22 & & $\mathrm{~N} / \mathrm{M}$ \\
\hline & 7 & & 1 & 1000 & 29 & 0.483 & 0.03448 & 2068.97 & & $\mathrm{~N} / \mathrm{M}$ \\
\hline & 8 & & 1 & 1000 & 29 & 0.483 & 0.03448 & 2068.97 & & $\mathrm{~N} / \mathrm{M}$ \\
\hline & 9 & & 1 & 1000 & 32 & 0.533 & 0.03125 & 1875.00 & & $\mathrm{~N} / \mathrm{M}$ \\
\hline & 9.7 & 1.41 & 0.7 & 700 & 25 & 0.417 & 0.02800 & 1680.00 & & $\mathrm{~N} / \mathrm{M}$ \\
\hline
\end{tabular}




\begin{tabular}{|c|c|c|c|c|c|c|c|c|c|c|}
\hline \multicolumn{11}{|c|}{ EXTERNAL FILTER (Bag \#2) - Run 3} \\
\hline Water & $\begin{array}{l}\text { Vol. } \\
\text { Filtered } \\
\quad \text { (L) }\end{array}$ & $\begin{array}{c}\text { Turbidity } \\
\text { (NTU) }\end{array}$ & \begin{tabular}{c|}
$\begin{array}{c}\text { Vol. of } \\
\text { Water } \\
\text { Discharged } \\
\text { (L) }\end{array}$ \\
\end{tabular} & $\begin{array}{c}\begin{array}{c}\text { Volume of } \\
\text { Water } \\
(\mathrm{mL})\end{array} \\
\end{array}$ & Time (sec) & Time $(\min )$ & $\begin{array}{c}\text { Flowrate } \\
\text { (L/sec) }\end{array}$ & $\begin{array}{l}\text { Flowrate } \\
(\mathrm{mL} / \mathrm{min})\end{array}$ & Ho (inch) & Hn (inch) \\
\hline \multirow[t]{6}{*}{$\begin{array}{c}\text { Raw } \\
\text { Water }\end{array}$} & 0 & & 0 & 0 & 0 & 0 & \#DIV/O! & 0 & & 33.00 \\
\hline & 2 & 0.69 & 2 & 2000 & 60 & 1.000 & 0.03333 & 2000.00 & 33.00 & 30.50 \\
\hline & 4 & 0.68 & 2 & 2000 & 27 & 0.450 & 0.07407 & 4444.44 & 30.50 & 28.50 \\
\hline & 6 & 0.67 & 2 & 2000 & 28 & 0.467 & 0.07143 & 4285.71 & 28.50 & 25.00 \\
\hline & 8 & 0.71 & 2 & 2000 & 61 & 1.017 & 0.03279 & 1967.21 & 25.00 & 19.50 \\
\hline & 10 & 0.70 & 2 & 2000 & 93 & 1.550 & 0.02151 & 1290.32 & 19.50 & 19.50 \\
\hline \multicolumn{11}{|c|}{$\begin{array}{l}\text { Notes: flipped filter to run from outside to inside; BAD IDEA because the inside of the filter was filled with } 20 \mathrm{~L} \text { worth of floc; } \\
\text { this caused a high initial turbidity. Initial flow rate was really low due to a kink in the tubing. No change in head as last } 2 \text { liters } \\
\text { drained out of external pouch. }\end{array}$} \\
\hline
\end{tabular}

\begin{tabular}{|c|c|c|c|c|r|r|r|r|r|r|}
\hline EXTERNAL FILTER (Bag \# 2) - Run 4 \\
\hline Water & $\begin{array}{c}\text { Vol. } \\
\text { Filtered } \\
\text { (L) }\end{array}$ & $\begin{array}{c}\text { Turbidity } \\
\text { (NTU) }\end{array}$ & $\begin{array}{c}\text { Vol. of } \\
\text { Water } \\
\text { Discharged } \\
\text { (L) }\end{array}$ & $\begin{array}{c}\text { Volume of } \\
\text { Water } \\
\text { (mL) }\end{array}$ & Time (sec) & Time (min) & $\begin{array}{c}\text { Flowrate } \\
\text { (L/sec) }\end{array}$ & $\begin{array}{c}\text { Flowrate } \\
\text { (mL/min) }\end{array}$ & Ho (inch) & Hn (inch) \\
\hline $\begin{array}{c}\text { Raw } \\
\text { Water }\end{array}$ & 0 & & 0 & 0 & 0 & 0 & \#DIV/0! & 0 & & 34.00 \\
\hline & 2 & 0.62 & 2 & 2000 & 30 & 0.500 & 0.06667 & 4000.00 & 34.00 & 31.50 \\
\hline & 4 & 0.57 & 2 & 2000 & 30 & 0.500 & 0.06667 & 4000.00 & 31.50 & 29.25 \\
\hline & 6 & 0.67 & 2 & 2000 & 36 & 0.600 & 0.05556 & 3333.33 & 29.25 & 26.50 \\
\hline & 8 & 0.41 & 2 & 2000 & 35 & 0.583 & 0.05714 & 3428.57 & 26.50 & 22.75 \\
\hline & 10 & 0.48 & 2 & 2000 & 45 & 0.750 & 0.04444 & 2666.67 & 22.75 & 18.50 \\
\hline Notes:
\end{tabular}

\begin{tabular}{|c|c|c|c|c|r|r|r|r|r|r|}
\hline EXTERNAL FILTER (Bag \# 2) - Run 5 \\
\hline Water & $\begin{array}{c}\text { Vol. } \\
\text { Filtered } \\
\text { (L) }\end{array}$ & $\begin{array}{c}\text { Turbidity } \\
\text { (NTU) }\end{array}$ & $\begin{array}{c}\text { Vol. of } \\
\text { Water } \\
\text { Discharged } \\
\text { (L) }\end{array}$ & $\begin{array}{c}\text { Volume of } \\
\text { Water } \\
\text { (mL) }\end{array}$ & Time (sec) & Time (min) & $\begin{array}{c}\text { Flowrate } \\
\text { (L/sec) }\end{array}$ & $\begin{array}{c}\text { Flowrate } \\
\text { (mL/min) }\end{array}$ & Ho (inch) & Hn (inch) \\
\hline $\begin{array}{c}\text { Raw } \\
\text { Water }\end{array}$ & 0 & & 0 & 0 & 0 & 0 & \#DIV/0! & 0 & & 33.75 \\
\hline & 2 & 0.44 & 2 & 2000 & 30 & 0.500 & 0.06667 & 4000.00 & 33.75 & 31.75 \\
\hline & 4 & 0.56 & 2 & 2000 & 30 & 0.500 & 0.06667 & 4000.00 & 31.75 & 29.25 \\
\hline & 6 & 0.48 & 2 & 2000 & 36 & 0.600 & 0.05556 & 3333.33 & 29.25 & 26.50 \\
\hline & 8 & 0.53 & 2 & 2000 & 35 & 0.583 & 0.05714 & 3428.57 & 26.50 & 22.75 \\
\hline & 10 & 0.53 & 2 & 2000 & 45 & 0.750 & 0.04444 & 2666.67 & 22.75 & 19.50 \\
\hline Notes: & & & & & & & & \\
\hline
\end{tabular}




\section{EXPERIMENT B-2}

\begin{tabular}{|c|c|c|c|c|c|c|c|c|c|c|}
\hline \multicolumn{11}{|c|}{ OUT --> IN FILTER - RUn 1} \\
\hline Water & $\begin{array}{l}\text { Total Vol. } \\
\text { Filtered (L) }\end{array}$ & Turbidity (NTU) & $\begin{array}{l}\text { Vol. of Water } \\
\text { Discharged (L) }\end{array}$ & $\begin{array}{l}\text { Volume of } \\
\text { Water }(\mathrm{mL})\end{array}$ & Time (sec) & Time $(\mathrm{min})$ & $\begin{array}{c}\text { Flowrate } \\
\text { (L/sec) }\end{array}$ & $\begin{array}{l}\text { Flowrate } \\
\text { (mL/min) }\end{array}$ & Ho (inch) & Hn (inch) \\
\hline \multirow[t]{5}{*}{ Raw Water } & 0 & 499 & 0 & 0 & 0 & 0 & \#DIV/O! & 0 & & 37.00 \\
\hline & 2 & 1.20 & 2 & 2000 & 133 & 2.217 & 0.01504 & 902.26 & 37.00 & 35.00 \\
\hline & 4 & 1.08 & 2 & 2000 & 187 & 3.117 & 0.01070 & 641.71 & 35.00 & 33.00 \\
\hline & 6 & 0.98 & 2 & 2000 & 275 & 4.583 & 0.00727 & 436.36 & 33.00 & 28.00 \\
\hline & 7 & 1.29 & 1 & 1000 & $n / a$ & \#VALUE! & \#VALUE! & \#VALUE! & 28.00 & 26.00 \\
\hline
\end{tabular}

\begin{tabular}{|c|c|c|c|c|c|c|c|c|c|c|}
\hline \multicolumn{11}{|c|}{ OUT --> IN FILTER - RUn 2} \\
\hline Water & $\begin{array}{l}\text { Total Vol. } \\
\text { Filtered (L) }\end{array}$ & Turbidity (NTU) & $\begin{array}{l}\text { Vol. of Water } \\
\text { Discharged (L) }\end{array}$ & $\begin{array}{l}\text { Volume of } \\
\text { Water }(\mathrm{mL})\end{array}$ & Time (sec) & Time $(\mathrm{min})$ & $\begin{array}{c}\text { Flowrate } \\
\text { (L/sec) }\end{array}$ & $\begin{array}{l}\text { Flowrate } \\
(\mathrm{mL} / \mathrm{min})\end{array}$ & Ho (inch) & Hn (inch) \\
\hline \multirow[t]{5}{*}{ Raw Water } & 0 & 419 & 0 & 0 & 0 & 0 & \#DIV/O! & 0 & & 36.00 \\
\hline & 2 & 0.90 & 2 & 2000 & 83 & 1.383 & 0.02410 & 1445.78 & 36.00 & 33.50 \\
\hline & 4 & 0.95 & 2 & 2000 & 159 & 2.650 & 0.01258 & 754.72 & 33.50 & 30.00 \\
\hline & 6 & 0.98 & 2 & 2000 & 245 & 4.083 & 0.00816 & 489.80 & 30.00 & 26.50 \\
\hline & 6.25 & 1.18 & 0.25 & 250 & 124 & 2.067 & 0.00202 & 120.97 & 26.50 & 26.00 \\
\hline
\end{tabular}

\begin{tabular}{|c|c|c|c|c|c|c|c|c|c|c|}
\hline \multicolumn{11}{|c|}{ OUT --> IN FILTER - Run 3} \\
\hline Water & $\begin{array}{c}\text { Total Vol. } \\
\text { Filtered (L) }\end{array}$ & Turbidity (NTU) & $\begin{array}{l}\text { Vol. of Water } \\
\text { Discharged (L) }\end{array}$ & $\begin{array}{c}\text { Volume of } \\
\text { Water }(\mathrm{mL})\end{array}$ & Time (sec) & Time $(\mathrm{min})$ & $\begin{array}{c}\begin{array}{c}\text { Flowrate } \\
(\mathrm{L} / \mathrm{sec})\end{array} \\
\end{array}$ & $\begin{array}{l}\text { Flowrate } \\
(\mathrm{mL} / \mathrm{min})\end{array}$ & Ho (inch) & Hn (inch) \\
\hline \multirow[t]{5}{*}{ Raw Water } & 0 & 461 & 0 & 0 & 0 & 0 & \#DIV/O! & 0 & & 36.50 \\
\hline & 2 & 0.86 & 2 & 2000 & 85 & 1.417 & 0.02353 & 1411.76 & 36.50 & 34.00 \\
\hline & 4 & 0.93 & 2 & 2000 & 87 & 1.450 & 0.02299 & 1379.31 & 34.00 & 31.00 \\
\hline & 6 & 0.82 & 2 & 2000 & 91 & 1.517 & 0.02198 & 1318.68 & 31.00 & 28.00 \\
\hline & 6.95 & 0.93 & 0.95 & 950 & 124 & 2.067 & 0.00766 & 459.68 & 28.00 & 26.50 \\
\hline
\end{tabular}

\begin{tabular}{|c|c|c|c|c|c|c|c|c|c|c|}
\hline \multicolumn{11}{|c|}{ OUT --> IN FILTER - RUn 4} \\
\hline Water & $\begin{array}{l}\text { Total Vol. } \\
\text { Filtered (L) }\end{array}$ & Turbidity (NTU) & $\begin{array}{l}\text { Vol. of Water } \\
\text { Discharged (L) }\end{array}$ & $\begin{array}{l}\text { Volume of } \\
\text { Water }(\mathrm{mL})\end{array}$ & Time (sec) & Time $(\mathrm{min})$ & $\begin{array}{c}\text { Flowrate } \\
\text { (L/sec) }\end{array}$ & $\begin{array}{l}\text { Flowrate } \\
\text { (mL/min) }\end{array}$ & Ho (inch) & Hn (inch) \\
\hline \multirow[t]{5}{*}{ Raw Water } & 0 & 440 & 0 & 0 & 0 & 0 & \#DIV/O! & 0 & & 36.00 \\
\hline & 2 & 1.02 & 2 & 2000 & 69 & 1.150 & 0.02899 & 1739.13 & 36.00 & 34.50 \\
\hline & 4 & 0.92 & 2 & 2000 & 72 & 1.200 & 0.02778 & 1666.67 & 34.50 & 32.00 \\
\hline & 6 & 0.96 & 2 & 2000 & 81 & 1.350 & 0.02469 & 1481.48 & 32.00 & 28.50 \\
\hline & 8 & 1.15 & 2 & 2000 & 253 & 4.217 & 0.00791 & 474.31 & 28.50 & 25.00 \\
\hline
\end{tabular}

\begin{tabular}{|c|c|c|c|c|c|c|c|c|c|c|}
\hline \multicolumn{11}{|c|}{ OUT --> IN FILTER - RUn 5} \\
\hline Water & $\begin{array}{l}\text { Total Vol. } \\
\text { Filtered (L) }\end{array}$ & Turbidity (NTU) & $\begin{array}{l}\text { Vol. of Water } \\
\text { Discharged (L) }\end{array}$ & $\begin{array}{l}\begin{array}{l}\text { Volume of } \\
\text { Water }(\mathrm{mL})\end{array} \\
\end{array}$ & Time (sec) & Time $(\mathrm{min})$ & $\begin{array}{c}\begin{array}{c}\text { Flowrate } \\
\text { (L/sec) }\end{array} \\
\end{array}$ & $\begin{array}{l}\text { Flowrate } \\
\text { (mL/min) }\end{array}$ & Ho (inch) & Hn (inch) \\
\hline \multirow[t]{5}{*}{ Raw Water } & 0 & 511 & 0 & 0 & 0 & 0 & \#DIV/O! & 0 & & 36.00 \\
\hline & 2 & 1.75 & 2 & 2000 & 77 & 1.283 & 0.02597 & 1558.44 & 36.00 & 34.50 \\
\hline & 4 & 1.06 & 2 & 2000 & 73 & 1.217 & 0.02740 & 1643.84 & 34.50 & 32.50 \\
\hline & 6 & 0.94 & 2 & 2000 & 82 & 1.367 & 0.02439 & 1463.41 & 32.50 & 29.25 \\
\hline & 8 & 1.01 & 2 & 2000 & 144 & 2.400 & 0.01389 & 833.33 & 29.25 & 26.00 \\
\hline Notes: & & & & & & & & & & \\
\hline
\end{tabular}




\begin{tabular}{|c|c|c|c|c|c|c|c|c|c|c|}
\hline \multicolumn{11}{|c|}{ OUT --> IN FILTER - RUn 6} \\
\hline Water & $\begin{array}{l}\text { Total Vol. } \\
\text { Filtered (L) }\end{array}$ & Turbidity (NTU) & $\begin{array}{l}\text { Vol. of Water } \\
\text { Discharged (L) }\end{array}$ & $\begin{array}{c}\text { Volume of } \\
\text { Water }(\mathrm{mL})\end{array}$ & Time (sec) & Time $(\mathrm{min})$ & $\begin{array}{c}\text { Flowrate } \\
\text { (L/sec) }\end{array}$ & $\begin{array}{l}\text { Flowrate } \\
(\mathrm{mL} / \mathrm{min})\end{array}$ & Ho (inch) & Hn (inch) \\
\hline \multirow[t]{6}{*}{ Raw Water } & 0 & 478 & 0 & 0 & 0 & 0 & \#DIV/O! & 0 & & 36.75 \\
\hline & 2 & 1.11 & 2 & 2000 & 67 & 1.117 & 0.02985 & 1791.04 & 36.75 & 34.75 \\
\hline & 4 & 0.97 & 2 & 2000 & 76 & 1.267 & 0.02632 & 1578.95 & 34.75 & 32.50 \\
\hline & 6 & 0.91 & 2 & 2000 & 85 & 1.417 & 0.02353 & 1411.76 & 32.50 & 28.75 \\
\hline & 8 & 0.96 & 2 & 2000 & 122 & 2.033 & 0.01639 & 983.61 & 28.75 & 25.00 \\
\hline & 8.45 & 0.89 & 0.45 & 450 & 93 & 1.550 & 0.00484 & 290.32 & 25.00 & 24.50 \\
\hline Notes: & & & & & & & & & & \\
\hline
\end{tabular}

\begin{tabular}{|c|c|c|c|c|c|c|c|c|c|c|}
\hline \multicolumn{11}{|c|}{ OUT --> IN FILTER - RUn 7} \\
\hline Water & $\begin{array}{l}\text { Total Vol. } \\
\text { Filtered (L) }\end{array}$ & Turbidity (NTU) & $\begin{array}{l}\text { Vol. of Water } \\
\text { Discharged (L) }\end{array}$ & $\begin{array}{c}\text { Volume of } \\
\text { Water }(\mathrm{mL})\end{array}$ & Time (sec) & Time $(\mathrm{min})$ & $\begin{array}{c}\text { Flowrate } \\
(\mathrm{L} / \mathrm{sec})\end{array}$ & $\begin{array}{l}\text { Flowrate } \\
\text { (mL/min) }\end{array}$ & Ho (inch) & Hn (inch) \\
\hline \multirow[t]{5}{*}{ Raw Water } & 0 & 457 & 0 & 0 & 0 & 0 & \#DIV/O! & o & & 36.00 \\
\hline & 2 & 1.11 & 2 & 2000 & 86 & 1.433 & 0.02326 & 1395.35 & 36.00 & 35.00 \\
\hline & 4 & 0.94 & 2 & 2000 & 106 & 1.767 & 0.01887 & 1132.08 & 35.00 & 32.00 \\
\hline & 6 & 0.54 & 2 & 2000 & 98 & 1.633 & 0.02041 & 1224.49 & 32.00 & 28.00 \\
\hline & 8 & 0.88 & 2 & 2000 & 170 & 2.833 & 0.01176 & 705.88 & 28.00 & 24.00 \\
\hline \multicolumn{11}{|l|}{ Notes: } \\
\hline
\end{tabular}

\begin{tabular}{|c|c|c|c|c|c|c|c|c|c|c|}
\hline \multicolumn{11}{|c|}{ OUT --> IN FILTER - RUn 8} \\
\hline Water & $\begin{array}{c}\text { Total Vol. } \\
\text { Filtered (L) }\end{array}$ & Turbidity (NTU) & $\begin{array}{l}\text { Vol. of Water } \\
\text { Discharged (L) }\end{array}$ & $\begin{array}{c}\text { Volume of } \\
\text { Water }(\mathrm{mL})\end{array}$ & Time $(\mathrm{sec})$ & Time $(\mathrm{min})$ & $\begin{array}{c}\text { Flowrate } \\
(\mathrm{L} / \mathrm{sec})\end{array}$ & $\begin{array}{l}\text { Flowrate } \\
(\mathrm{mL} / \mathrm{min})\end{array}$ & Ho (inch) & Hn (inch) \\
\hline \multirow[t]{5}{*}{ Raw Water } & 0 & 409 & 0 & 0 & 0 & 0 & \#DIV/O! & 0 & & 37.00 \\
\hline & 2 & 0.59 & 2 & 2000 & 78 & 1.300 & 0.02564 & 1538.46 & 37.00 & 33.50 \\
\hline & 4 & 0.66 & 2 & 2000 & 72 & 1.200 & 0.02778 & 1666.67 & 33.50 & 30.50 \\
\hline & 6 & 0.39 & 2 & 2000 & 105 & 1.750 & 0.01905 & 1142.86 & 30.50 & 26.50 \\
\hline & 7 & 0.47 & 1 & 1000 & 80 & 1.333 & 0.01250 & 750.00 & 26.50 & 23.50 \\
\hline Notes: & & & & & & & & & & \\
\hline
\end{tabular}

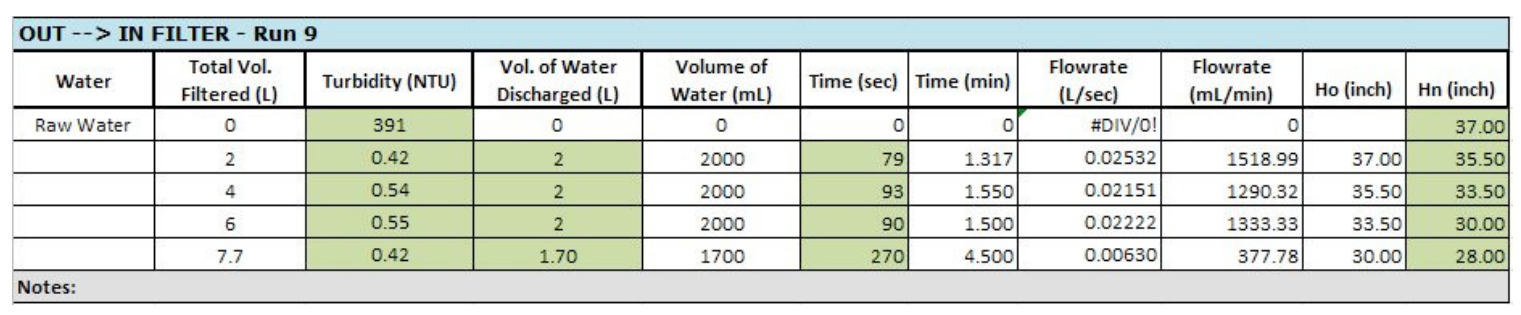

\begin{tabular}{|c|c|c|c|c|c|c|c|c|c|c|}
\hline \multicolumn{11}{|c|}{ OUT --> IN FILTER - Run 10} \\
\hline Water & $\begin{array}{l}\text { Total Vol. } \\
\text { Filtered (L) }\end{array}$ & Turbidity (NTU) & $\begin{array}{l}\text { Vol. of Water } \\
\text { Discharged (L) }\end{array}$ & $\begin{array}{c}\text { Volume of } \\
\text { Water }(\mathrm{mL})\end{array}$ & Time (sec) & Time $(\min )$ & $\begin{array}{c}\text { Flowrate } \\
(\mathrm{L} / \mathrm{sec})\end{array}$ & $\begin{array}{l}\text { Flowrate } \\
(\mathrm{mL} / \mathrm{min})\end{array}$ & Ho (inch) & $\mathrm{Hn}$ (inch) \\
\hline \multirow[t]{5}{*}{ Raw Water } & 0 & 531 & 0 & 0 & 0 & of & \#DIV/O! & 0 & & 37.00 \\
\hline & 2 & 0.65 & 2 & 2000 & 81 & 1.350 & 0.02469 & 1481.48 & 37.00 & 35.00 \\
\hline & 4 & 0.64 & 2 & 2000 & 91 & 1.517 & 0.02198 & 1318.68 & 35.00 & 32.00 \\
\hline & 6 & 0.64 & 2 & 2000 & 111 & 1.850 & 0.01802 & 1081.08 & 32.00 & 29.00 \\
\hline & 7.35 & 1.03 & 1.35 & 1350 & 240 & 4.000 & 0.00563 & 337.50 & 29.00 & 26.00 \\
\hline Notes: & & & & & & & & & & \\
\hline
\end{tabular}

\begin{tabular}{|c|c|c|c|c|c|c|c|c|c|c|}
\hline \multicolumn{11}{|c|}{ OUT --> IN FILTER - Run 11} \\
\hline Water & $\begin{array}{c}\text { Total Vol. } \\
\text { Filtered (L) }\end{array}$ & Turbidity (NTU) & $\begin{array}{l}\text { Vol. of Water } \\
\text { Discharged (L) }\end{array}$ & $\begin{array}{c}\text { Volume of } \\
\text { Water }(\mathrm{mL})\end{array}$ & Time (sec) & Time $(\mathrm{min})$ & $\begin{array}{c}\text { Flowrate } \\
\text { (L/sec) }\end{array}$ & $\begin{array}{l}\text { Flowrate } \\
\text { (mL/min) }\end{array}$ & Ho (inch) & Hn (inch) \\
\hline \multirow[t]{5}{*}{ Raw Water } & 0 & 520 & 0 & 0 & 0 & 0 & \#DIV/O! & 0 & & 36.50 \\
\hline & 2 & 0.65 & 2 & 2000 & 67 & 1.117 & 0.02985 & 1791.04 & 36.50 & 35.50 \\
\hline & 4 & 0.91 & 2 & 2000 & 79 & 1.317 & 0.02532 & 1518.99 & 35.50 & 33.50 \\
\hline & 6 & 0.90 & 2 & 2000 & 91 & 1.517 & 0.02198 & 1318.68 & 33.50 & 30.00 \\
\hline & 8 & 0.83 & 2 & 2000 & 147 & 2.450 & 0.01361 & 816.33 & 30.00 & 27.00 \\
\hline Notes: & & & & & & & & & & \\
\hline
\end{tabular}




\begin{tabular}{|c|c|c|c|c|c|c|c|c|c|c|}
\hline \multicolumn{11}{|c|}{ OUT --> IN FILTER - Run 12} \\
\hline Water & $\begin{array}{l}\text { Total Vol. } \\
\text { Filtered (L) }\end{array}$ & Turbidity (NTU) & $\begin{array}{l}\text { Vol. of Water } \\
\text { Discharged (L) }\end{array}$ & $\begin{array}{l}\text { Volume of } \\
\text { Water }(\mathrm{mL})\end{array}$ & Time (sec) & Time $(\mathrm{min})$ & $\begin{array}{c}\text { Flowrate } \\
\text { (L/sec) }\end{array}$ & $\begin{array}{l}\text { Flowrate } \\
\text { (mL/min) }\end{array}$ & Ho (inch) & $\mathrm{Hn}$ (inch) \\
\hline \multirow[t]{5}{*}{ Raw Water } & 0 & 424 & 0 & 0 & 0 & 0 & \#DIV/O! & 0 & & 35.50 \\
\hline & 2 & 0.56 & 2 & 2000 & 84 & 1.400 & 0.02381 & 1428.57 & 35.50 & 33.00 \\
\hline & 4 & 0.59 & 2 & 2000 & 84 & 1.400 & 0.02381 & 1428.57 & 33.00 & 31.00 \\
\hline & 6 & 0.60 & 2 & 2000 & 98 & 1.633 & 0.02041 & 1224.49 & 31.00 & 27.00 \\
\hline & 7.55 & 0.55 & 1.55 & 1550 & 180 & 3.000 & 0.00861 & 516.67 & 27.00 & 25.00 \\
\hline
\end{tabular}

\section{EXPERIMENT B-3}

\begin{tabular}{|c|c|c|c|c|c|c|c|c|c|c|}
\hline \multicolumn{11}{|c|}{ IN --> OUT FILTER - RUn 1} \\
\hline Water & $\begin{array}{c}\text { Total Vol. } \\
\text { Filtered (L) }\end{array}$ & Turbidity (NTU) & $\begin{array}{l}\text { Vol. of Water } \\
\text { Discharged (L) }\end{array}$ & $\begin{array}{c}\text { Volume of } \\
\text { Water }(\mathrm{mL})\end{array}$ & Time (sec) & Time $(\min )$ & $\begin{array}{c}\text { Flowrate } \\
(\mathrm{L} / \mathrm{sec})\end{array}$ & $\begin{array}{l}\text { Flowrate } \\
(\mathrm{mL} / \mathrm{min})\end{array}$ & Ho (inch) & Hn (inch) \\
\hline \multirow[t]{5}{*}{ Raw Water } & 0 & 499 & 0 & 0 & 0 & 0 & \#DIV/O! & 0 & & 38.00 \\
\hline & 2 & 1.06 & 2 & 2000 & 140 & 2.333 & 0.01429 & 857.14 & 38.00 & 36.50 \\
\hline & 4 & 1.06 & 2 & 2000 & 206 & 3.433 & 0.00971 & 582.52 & 36.50 & 34.00 \\
\hline & 6 & 1.71 & 2 & 2000 & 390 & 6.500 & 0.00513 & 307.69 & 34.00 & 30.50 \\
\hline & 8 & 1.29 & 2 & 2000 & $\mathrm{n} / \mathrm{a}$ & \#VALUE! & \#VALUE! & \#VALUE! & 30.50 & 26.00 \\
\hline
\end{tabular}

\begin{tabular}{|c|c|c|c|c|c|c|c|c|c|c|}
\hline \multicolumn{11}{|c|}{ IN --> OUT FILTER - Run 2} \\
\hline Water & $\begin{array}{c}\text { Total Vol. } \\
\text { Filtered (L) }\end{array}$ & Turbidity (NTU) & $\begin{array}{l}\text { Vol. of Water } \\
\text { Discharged (L) }\end{array}$ & $\begin{array}{c}\text { Volume of } \\
\text { Water }(\mathrm{mL})\end{array}$ & Time (sec) & Time $(\mathrm{min})$ & $\begin{array}{c}\text { Flowrate } \\
\text { (L/sec) }\end{array}$ & $\begin{array}{l}\text { Flowrate } \\
(\mathrm{mL} / \mathrm{min})\end{array}$ & Ho (inch) & Hn (inch) \\
\hline \multirow[t]{6}{*}{ Raw Water } & 0 & 419 & 0 & 0 & 0 & 0 & \#DIV $/ 0$ ! & 0 & & 37.00 \\
\hline & 2 & 1.04 & 2 & 2000 & 203 & 3.383 & 0.00985 & 591.13 & 37.00 & 35.00 \\
\hline & 4 & 0.72 & 2 & 2000 & 110 & 1.833 & 0.01818 & 1090.91 & 35.00 & 32.00 \\
\hline & 6 & 0.80 & 2 & 2000 & 100 & 1.667 & 0.02000 & 1200.00 & 32.00 & 27.50 \\
\hline & 8 & 1.07 & 2 & 2000 & 115 & 1.917 & 0.01739 & 1043.48 & 27.50 & 23.00 \\
\hline & 8.75 & 0.82 & 0.75 & 750 & 75 & 1.250 & 0.01000 & 600.00 & 23.00 & 21.00 \\
\hline \multicolumn{11}{|l|}{ Notes: } \\
\hline
\end{tabular}

\begin{tabular}{|c|c|c|c|c|c|c|c|c|c|c|}
\hline \multicolumn{11}{|c|}{ IN --> OUT FILTER - Run 3} \\
\hline Water & $\begin{array}{l}\text { Total Vol. } \\
\text { Filtered (L) }\end{array}$ & Turbidity (NTU) & $\begin{array}{l}\text { Vol. of Water } \\
\text { Discharged (L) }\end{array}$ & $\begin{array}{l}\text { Volume of } \\
\text { Water }(\mathrm{mL})\end{array}$ & Time (sec) & Time (min) & $\begin{array}{c}\text { Flowrate } \\
\text { (L/sec) }\end{array}$ & $\begin{array}{l}\text { Flowrate } \\
\text { (mL/min) }\end{array}$ & Ho (inch) & Hn (inch) \\
\hline \multirow[t]{6}{*}{ Raw Water } & 0 & 461 & 0 & 0 & 0 & 0 & \#DIV/O! & 0 & & 37.00 \\
\hline & 2 & 1.32 & 2 & 2000 & 83 & 1.383 & 0.02410 & 1445.78 & 37.00 & 34.00 \\
\hline & 4 & 1.89 & 2 & 2000 & 76 & 1.267 & 0.02632 & 1578.95 & 34.00 & 31.50 \\
\hline & 6 & 0.79 & 2 & 2000 & 86 & 1.433 & 0.02326 & 1395.35 & 31.50 & 27.75 \\
\hline & 8 & 0.77 & 2 & 2000 & 155 & 2.583 & 0.01290 & 774.19 & 27.75 & 22.25 \\
\hline & 8.7 & 0.92 & 0.7 & 700 & 180 & 3.000 & 0.00389 & 233.33 & 22.25 & 20.75 \\
\hline Notes: & & & & & & & & & & \\
\hline
\end{tabular}

\begin{tabular}{|c|c|c|c|c|c|c|c|c|c|c|}
\hline \multicolumn{11}{|c|}{ IN --> OUT FILTER - RUn 4} \\
\hline Water & $\begin{array}{c}\text { Total Vol. } \\
\text { Filtered (L) }\end{array}$ & Turbidity (NTU) & $\begin{array}{l}\text { Vol. of Water } \\
\text { Discharged (L) }\end{array}$ & $\begin{array}{l}\text { Volume of } \\
\text { Water }(\mathrm{mL})\end{array}$ & Time (sec) & Time $(\mathrm{min})$ & $\begin{array}{c}\text { Flowrate } \\
\text { (L/sec) }\end{array}$ & $\begin{array}{l}\text { Flowrate } \\
\text { (mL/min) }\end{array}$ & Ho (inch) & $\mathrm{Hn}$ (inch) \\
\hline \multirow[t]{6}{*}{ Raw Water } & 0 & 440 & 0 & 0 & 0 & o & \#DIV/O! & 0 & & 37.00 \\
\hline & 2 & 0.80 & 2 & 2000 & 77 & 1.283 & 0.02597 & 1558.44 & 37.00 & 35.00 \\
\hline & 4 & 0.68 & 2 & 2000 & 77 & 1.283 & 0.02597 & 1558.44 & 35.00 & 32.50 \\
\hline & 6 & 0.65 & 2 & 2000 & 95 & 1.583 & 0.02105 & 1263.16 & 32.50 & 29.00 \\
\hline & 8 & 0.73 & 2 & 2000 & 158 & 2.633 & 0.01266 & 759.49 & 29.00 & 24.50 \\
\hline & 8.6 & 0.73 & 0.6 & 600 & 163 & 2.717 & 0.00368 & 220.86 & 24.50 & 22.25 \\
\hline \multicolumn{11}{|c|}{ Notes: steady drip out of bag, unsure if from filter bag or possibly hole in Cascade bag, covered in duct tape } \\
\hline
\end{tabular}




\begin{tabular}{|c|c|c|c|c|c|c|c|c|c|c|}
\hline \multicolumn{11}{|c|}{ IN $-->$ OUT FILTER - Run 5} \\
\hline Water & $\begin{array}{l}\text { Total Vol. } \\
\text { Filtered (L) }\end{array}$ & Turbidity (NTU) & $\begin{array}{l}\text { Vol. of Water } \\
\text { Discharged (L) }\end{array}$ & $\begin{array}{c}\text { Volume of } \\
\text { Water }(\mathrm{mL})\end{array}$ & Time (sec) & Time $(\min )$ & $\begin{array}{c}\text { Flowrate } \\
\text { (L/sec) }\end{array}$ & $\begin{array}{l}\text { Flowrate } \\
(\mathrm{mL} / \mathrm{min})\end{array}$ & Ho (inch) & Hn (inch) \\
\hline \multirow[t]{6}{*}{ Raw Water } & 0 & 511 & 0 & 0 & 0 & of & \#DIV/O! & 0 & & 36.00 \\
\hline & 2 & 1.00 & 2 & 2000 & 80 & 1.333 & 0.02500 & 1500.00 & 36.00 & 34.50 \\
\hline & 4 & 1.13 & 2 & 2000 & 75 & 1.250 & 0.02667 & 1600.00 & 34.50 & 31.00 \\
\hline & 6 & 0.85 & 2 & 2000 & 90 & 1.500 & 0.02222 & 1333.33 & 31.00 & 27.00 \\
\hline & 8 & 0.86 & 2 & 2000 & 162 & 2.700 & 0.01235 & 740.74 & 27.00 & 22.00 \\
\hline & 8.4 & 0.78 & 0.4 & 400 & 66 & 1.100 & 0.00606 & 363.64 & 22.00 & 21.50 \\
\hline \multicolumn{11}{|c|}{ Notes: steady drip out of bag, unsure if from filter bag or possibly hole in Cascade bag, covered in duct tape } \\
\hline
\end{tabular}

\begin{tabular}{|c|c|c|c|c|c|c|c|c|c|c|}
\hline \multicolumn{11}{|c|}{ IN --> OUT FILTER - RUn 6} \\
\hline Water & $\begin{array}{c}\text { Total Vol. } \\
\text { Filtered (L) }\end{array}$ & Turbidity (NTU) & $\begin{array}{l}\text { Vol. of Water } \\
\text { Discharged (L) }\end{array}$ & $\begin{array}{c}\text { Volume of } \\
\text { Water }(\mathrm{mL})\end{array}$ & Time (sec) & Time (min) & $\begin{array}{c}\text { Flowrate } \\
\text { (L/sec) }\end{array}$ & $\begin{array}{l}\text { Flowrate } \\
\text { (mL/min) }\end{array}$ & Ho (inch) & Hn (inch) \\
\hline \multirow[t]{6}{*}{ Raw Water } & 0 & 478 & 0 & 0 & 0 & 0 & \#DIV/O! & 0 & & 37.00 \\
\hline & 2 & 0.67 & 2 & 2000 & 77 & 1.283 & 0.02597 & 1558.44 & 37.00 & 34.00 \\
\hline & 4 & 0.68 & 2 & 2000 & 80 & 1.333 & 0.02500 & 1500.00 & 34.00 & 31.00 \\
\hline & 6 & 1.09 & 2 & 2000 & 101 & 1.683 & 0.01980 & 1188.12 & 31.00 & 26.75 \\
\hline & 8 & 0.73 & 2 & 2000 & 165 & 2.750 & 0.01212 & 727.27 & 26.75 & 21.75 \\
\hline & 8.45 & 0.66 & 0.45 & 450 & 75 & 1.250 & 0.00600 & 360.00 & 21.75 & 20.75 \\
\hline Notes: & & & & & & & & & & \\
\hline
\end{tabular}

\begin{tabular}{|c|c|c|c|c|c|c|c|c|c|c|}
\hline \multicolumn{11}{|c|}{ IN --> OUT FILTER - Run 7} \\
\hline Water & $\begin{array}{l}\text { Total Vol. } \\
\text { Filtered (L) }\end{array}$ & Turbidity (NTU) & $\begin{array}{l}\text { Vol. of Water } \\
\text { Discharged (L) }\end{array}$ & $\begin{array}{l}\text { Volume of } \\
\text { Water }(\mathrm{mL})\end{array}$ & Time $(\mathrm{sec})$ & Time $(\min )$ & $\begin{array}{c}\text { Flowrate } \\
\text { (L/sec) }\end{array}$ & $\begin{array}{l}\text { Flowrate } \\
\text { (mL/min) }\end{array}$ & Ho (inch) & Hn (inch) \\
\hline \multirow[t]{6}{*}{ Raw Water } & 0 & 457 & 0 & 0 & 0 & of & \#DIV/O! & 0 & & 38.00 \\
\hline & 2 & 0.99 & 2 & 2000 & 77 & 1.283 & 0.02597 & 1558.44 & 38.00 & 37.00 \\
\hline & 4 & 0.62 & 2 & 2000 & 85 & 1.417 & 0.02353 & 1411.76 & 37.00 & 32.00 \\
\hline & 6 & 0.68 & 2 & 2000 & 105 & 1.750 & 0.01905 & 1142.86 & 32.00 & 27.50 \\
\hline & 8 & 0.70 & 2 & 2000 & 174 & 2.900 & 0.01149 & 689.66 & 27.50 & 22.50 \\
\hline & 8.7 & 0.38 & 0.7 & 700 & 135 & 2.250 & 0.00519 & 311.11 & 22.50 & 21.00 \\
\hline \multicolumn{11}{|c|}{ Notes: metal clamp opened after 4 liters drawn out of bag } \\
\hline
\end{tabular}

\begin{tabular}{|c|c|c|c|c|c|c|c|c|c|c|}
\hline \multicolumn{11}{|c|}{ IN --> OUT FILTER - RUn 8} \\
\hline Water & $\begin{array}{l}\text { Total Vol. } \\
\text { Filtered (L) }\end{array}$ & Turbidity (NTU) & $\begin{array}{l}\text { Vol. of Water } \\
\text { Discharged (L) }\end{array}$ & $\begin{array}{c}\text { Volume of } \\
\text { Water }(\mathrm{mL})\end{array}$ & Time (sec) & Time $(\min )$ & $\begin{array}{c}\text { Flowrate } \\
\text { (L/sec) }\end{array}$ & $\begin{array}{l}\text { Flowrate } \\
(\mathrm{mL} / \mathrm{min})\end{array}$ & Ho (inch) & Hn (inch) \\
\hline \multirow[t]{5}{*}{ Raw Water } & 0 & 409 & 0 & 0 & 0 & of & \#DIV/O! & 0 & & 37.00 \\
\hline & 2 & 14.50 & 2 & 2000 & 75 & 1.250 & 0.02667 & 1600.00 & 37.00 & 34.00 \\
\hline & 4 & 0.95 & 2 & 2000 & 100 & 1.667 & 0.02000 & 1200.00 & 34.00 & 30.00 \\
\hline & 6 & 0.72 & 2 & 2000 & 95 & 1.583 & 0.02105 & 1263.16 & 30.00 & 25.00 \\
\hline & 7.1 & 0.64 & 1 & 1100 & 200 & 3.333 & 0.00550 & 330.00 & 25.00 & 22.00 \\
\hline
\end{tabular}

\begin{tabular}{|c|c|c|c|c|c|c|c|c|c|c|}
\hline \multicolumn{11}{|c|}{ IN --> OUT FILTER - Run 9} \\
\hline Water & $\begin{array}{c}\text { Total Vol. } \\
\text { Filtered (L) }\end{array}$ & Turbidity (NTU) & $\begin{array}{l}\text { Vol. of Water } \\
\text { Discharged (L) }\end{array}$ & $\begin{array}{c}\text { Volume of } \\
\text { Water }(\mathrm{mL})\end{array}$ & Time (sec) & Time $(\min )$ & $\begin{array}{c}\text { Flowrate } \\
(\mathrm{L} / \mathrm{sec})\end{array}$ & $\begin{array}{l}\text { Flowrate } \\
(\mathrm{mL} / \mathrm{min})\end{array}$ & Ho (inch) & Hn (inch) \\
\hline \multirow[t]{6}{*}{ Raw Water } & 0 & 391 & 0 & 0 & 0 & 0 & \#DIV/O! & 0 & & 36.00 \\
\hline & 2 & 0.82 & 2 & 2000 & 92 & 1.533 & 0.02174 & 1304.35 & 36.00 & 35.00 \\
\hline & 4 & 0.78 & 2 & 2000 & 98 & 1.633 & 0.02041 & 1224.49 & 35.00 & 31.50 \\
\hline & 6 & 0.65 & 2 & 2000 & 116 & 1.933 & 0.01724 & 1034.48 & 31.50 & 27.00 \\
\hline & 8 & 0.69 & 2 & 2000 & 290 & 4.833 & 0.00690 & 413.79 & 27.00 & 24.00 \\
\hline & 8.2 & 0.54 & 0.2 & 200 & 84 & 1.400 & 0.00238 & 142.86 & 24.00 & 21.00 \\
\hline
\end{tabular}




\begin{tabular}{|c|c|c|c|c|c|c|c|c|c|c|}
\hline \multicolumn{11}{|c|}{ IN --> OUT FILTER - Run 10} \\
\hline Water & $\begin{array}{l}\text { Total Vol. } \\
\text { Filtered (L) }\end{array}$ & Turbidity (NTU) & $\begin{array}{l}\text { Vol. of Water } \\
\text { Discharged (L) }\end{array}$ & $\begin{array}{c}\text { Volume of } \\
\text { Water }(\mathrm{mL})\end{array}$ & Time (sec) & Time (min) & $\begin{array}{c}\text { Flowrate } \\
\text { (L/sec) }\end{array}$ & $\begin{array}{l}\text { Flowrate } \\
(\mathrm{mL} / \mathrm{min})\end{array}$ & Ho (inch) & $\mathrm{Hn}$ (inch) \\
\hline \multirow[t]{5}{*}{ Raw Water } & 0 & 531 & 0 & 0 & 0 & 0 & \#DIV/O! & 0 & & 36.50 \\
\hline & 2 & 1.22 & 2 & 2000 & 100 & 1.667 & 0.02000 & 1200.00 & 36.50 & 34.00 \\
\hline & 4 & 0.72 & 2 & 2000 & 108 & 1.800 & 0.01852 & 1111.11 & 34.00 & 30.00 \\
\hline & 6 & 0.63 & 2 & 2000 & 160 & 2.667 & 0.01250 & 750.00 & 30.00 & 25.00 \\
\hline & 7.5 & 0.63 & 1.50 & 1500 & 257 & 4.283 & 0.00584 & 350.19 & 25.00 & 23.00 \\
\hline Notes: & & & & & & & & & & \\
\hline
\end{tabular}

\begin{tabular}{|c|c|c|c|c|c|c|c|c|c|c|}
\hline \multicolumn{11}{|c|}{ IN --> OUT FILTER - Run 11} \\
\hline Water & $\begin{array}{c}\text { Total Vol. } \\
\text { Filtered (L) }\end{array}$ & Turbidity (NTU) & $\begin{array}{l}\text { Vol. of Water } \\
\text { Discharged (L) }\end{array}$ & $\begin{array}{c}\text { Volume of } \\
\text { Water }(\mathrm{mL})\end{array}$ & Time (sec) & Time (min) & $\begin{array}{c}\text { Flowrate } \\
\text { (L/sec) }\end{array}$ & $\begin{array}{l}\text { Flowrate } \\
\text { (mL/min) }\end{array}$ & Ho (inch) & Hn (inch) \\
\hline \multirow[t]{5}{*}{ Raw Water } & 0 & 520 & 0 & 0 & 0 & 0 & \#DIV/O! & 0 & & 37.00 \\
\hline & 2 & 0.59 & 2 & 2000 & 91 & 1.517 & 0.02198 & 1318.68 & 37.00 & 35.00 \\
\hline & 4 & 0.51 & 2 & 2000 & 102 & 1.700 & 0.01961 & 1176.47 & 35.00 & 31.50 \\
\hline & 6 & 0.62 & 2 & 2000 & 134 & 2.233 & 0.01493 & 895.52 & 31.50 & 27.50 \\
\hline & 8 & 0.55 & 2 & 2000 & 200 & 3.333 & 0.01000 & 600.00 & 27.50 & 23.00 \\
\hline \multicolumn{11}{|l|}{ Notes: } \\
\hline
\end{tabular}

\begin{tabular}{|c|c|c|c|c|c|c|c|c|c|c|}
\hline \multicolumn{11}{|c|}{ IN --> OUT FILTER - Run 12} \\
\hline Water & $\begin{array}{l}\text { Total Vol. } \\
\text { Filtered (L) }\end{array}$ & Turbidity (NTU) & $\begin{array}{l}\text { Vol. of Water } \\
\text { Discharged (L) }\end{array}$ & $\begin{array}{l}\text { Volume of } \\
\text { Water }(\mathrm{mL})\end{array}$ & Time $(\mathrm{sec})$ & Time $(\min )$ & $\begin{array}{c}\text { Flowrate } \\
\text { (L/sec) }\end{array}$ & $\begin{array}{l}\text { Flowrate } \\
\text { (mL/min) }\end{array}$ & Ho (inch) & $\mathrm{Hn}$ (inch) \\
\hline \multirow[t]{5}{*}{ Raw Water } & 0 & 424 & 0 & 0 & 0 & 0 & \#DIV/O! & 0 & & 37.00 \\
\hline & 2 & 0.88 & 2 & 2000 & 90 & 1.500 & 0.02222 & 1333.33 & 37.00 & 34.50 \\
\hline & 4 & 0.81 & 2 & 2000 & 108 & 1.800 & 0.01852 & 1111.11 & 34.50 & 32.00 \\
\hline & 6 & 0.84 & 2 & 2000 & 118 & 1.967 & 0.01695 & 1016.95 & 32.00 & 28.50 \\
\hline & 8 & 0.73 & 2 & 2000 & 191 & 3.183 & 0.01047 & 628.27 & 28.50 & 23.50 \\
\hline
\end{tabular}

\section{EXPERIMENT C-1}

\begin{tabular}{|c|c|c|c|c|c|c|c|c|c|c|}
\hline \multicolumn{11}{|c|}{ In --> Out, parallel bulk heads FILTER - Run 1} \\
\hline Water & $\begin{array}{l}\text { Total Vol. } \\
\text { Filtered (L) }\end{array}$ & Turbidity (NTU) & $\begin{array}{l}\text { Vol. of Water } \\
\text { Discharged (L) }\end{array}$ & $\begin{array}{l}\text { Volume of } \\
\text { Water }(\mathrm{mL})\end{array}$ & Time (sec) & Time (min) & $\begin{array}{c}\text { Flowrate } \\
\text { (L/sec) }\end{array}$ & $\begin{array}{l}\text { Flowrate } \\
(\mathrm{mL} / \mathrm{min})\end{array}$ & Ho (inch) & $\mathrm{Hn}$ (inch) \\
\hline \multirow[t]{5}{*}{ Raw Water } & 0 & 451 & 0 & 0 & 0 & 0 & \#DIV/O! & 0 & & 37.00 \\
\hline & 2 & 0.90 & 2 & 2000 & 160 & 2.667 & 0.01250 & 750.00 & 37.00 & 36.00 \\
\hline & 4 & 0.88 & 2 & 2000 & 125 & 2.083 & 0.01600 & 960.00 & 36.00 & 34.00 \\
\hline & 6 & 0.72 & 2 & 2000 & 155 & 2.583 & 0.01290 & 774.19 & 34.00 & 30.50 \\
\hline & 8 & 0.59 & 2 & 2000 & 323 & 5.383 & 0.00619 & 371.52 & 30.50 & 26.00 \\
\hline \multicolumn{11}{|l|}{ Notes: } \\
\hline
\end{tabular}

\begin{tabular}{|c|c|c|c|c|c|c|c|c|c|c|}
\hline \multicolumn{11}{|c|}{ In --> Out, parallel bulk heads FILTER - Run 2} \\
\hline Water & $\begin{array}{l}\text { Total Vol. } \\
\text { Filtered (L) }\end{array}$ & Turbidity (NTU) & $\begin{array}{l}\text { Vol. of Water } \\
\text { Discharged (L) }\end{array}$ & $\begin{array}{c}\text { Volume of } \\
\text { Water }(\mathrm{mL})\end{array}$ & Time (sec) & Time $(\mathrm{min})$ & $\begin{array}{c}\text { Flowrate } \\
\text { (L/sec) }\end{array}$ & $\begin{array}{l}\text { Flowrate } \\
(\mathrm{mL} / \mathrm{min})\end{array}$ & Ho (inch) & $\mathrm{Hn}$ (inch) \\
\hline \multirow[t]{6}{*}{ Raw Water } & 0 & 427 & 0 & 0 & 0 & 0 & \#DIV/0! & 0 & & 38.50 \\
\hline & 2 & 0.71 & 2 & 2000 & 121 & 2.017 & 0.01653 & 991.74 & 38.50 & 37.00 \\
\hline & 4 & 0.69 & 2 & 2000 & 105 & 1.750 & 0.01905 & 1142.86 & 37.00 & 34.00 \\
\hline & 6 & 0.61 & 2 & 2000 & 123 & 2.050 & 0.01626 & 975.61 & 34.00 & 31.00 \\
\hline & 8 & 0.55 & 2 & 2000 & 157 & 2.617 & 0.01274 & 764.33 & 31.00 & 26.00 \\
\hline & 8.8 & 0.65 & 0.8 & 800 & 210 & 3.500 & 0.00381 & 228.57 & 26.00 & 23.50 \\
\hline Notes: & & & & & & & & & & \\
\hline
\end{tabular}




\begin{tabular}{|c|c|c|c|c|c|c|c|c|c|c|}
\hline \multicolumn{11}{|c|}{ In $-->$ Out, parallel bulk heads FILTER - Run 3} \\
\hline Water & $\begin{array}{l}\text { Total Vol. } \\
\text { Filtered (L) }\end{array}$ & Turbidity (NTU) & $\begin{array}{l}\text { Vol. of Water } \\
\text { Discharged (L) }\end{array}$ & $\begin{array}{r}\text { Volume of } \\
\text { Water }(\mathrm{mL})\end{array}$ & Time $(\mathrm{sec})$ & Time (min) & $\begin{array}{c}\text { Flowrate } \\
\text { (L/sec) }\end{array}$ & $\begin{array}{l}\text { Flowrate } \\
(\mathrm{mL} / \mathrm{min})\end{array}$ & Ho (inch) & Hn (inch) \\
\hline \multirow[t]{5}{*}{ Raw Water } & 0 & 367 & 0 & 0 & 0 & 0 & \#DIV/O! & 0 & & 36.50 \\
\hline & 2 & 0.60 & 2 & 2000 & 124 & 2.067 & 0.01613 & 967.74 & 36.50 & 34.00 \\
\hline & 4 & 0.50 & 2 & 2000 & 120 & 2.000 & 0.01667 & 1000.00 & 34.00 & 30.50 \\
\hline & 6 & 0.39 & 2 & 2000 & 134 & 2.233 & 0.01493 & 895.52 & 30.50 & 28.00 \\
\hline & 8 & 0.57 & 2 & 2000 & 259 & 4.317 & 0.00772 & 463.32 & 28.00 & 26.00 \\
\hline
\end{tabular}

\begin{tabular}{|c|c|c|c|c|c|c|c|c|c|c|}
\hline \multicolumn{11}{|c|}{ In --> Out, parallel bulk heads FILTER - Run 4} \\
\hline Water & $\begin{array}{l}\text { Total Vol. } \\
\text { Filtered (L) }\end{array}$ & Turbidity (NTU) & $\begin{array}{l}\text { Vol. of Water } \\
\text { Discharged (L) }\end{array}$ & $\begin{array}{c}\text { Volume of } \\
\text { Water }(\mathrm{mL})\end{array}$ & Time (sec) & Time $(\mathrm{min})$ & $\begin{array}{c}\text { Flowrate } \\
\text { (L/sec) }\end{array}$ & $\begin{array}{l}\text { Flowrate } \\
(\mathrm{mL} / \mathrm{min})\end{array}$ & Ho (inch) & Hn (inch) \\
\hline \multirow[t]{5}{*}{ Raw Water } & 0 & 389 & 0 & 0 & 0 & 0 & \#DIV/O! & 0 & & 37.00 \\
\hline & 2 & 0.65 & 2 & 2000 & 125 & 2.083 & 0.01600 & 960.00 & 37.00 & 34.50 \\
\hline & 4 & 0.38 & 2 & 2000 & 120 & 2.000 & 0.01667 & 1000.00 & 34.50 & 30.00 \\
\hline & 6 & 0.39 & 2 & 2000 & 134 & 2.233 & 0.01493 & 895.52 & 30.00 & 27.00 \\
\hline & 7.5 & 0.28 & 2 & 1500 & 244 & 4.067 & 0.00615 & 368.85 & 27.00 & 25.00 \\
\hline Notes: & & & & & & & & & & \\
\hline
\end{tabular}

\begin{tabular}{|c|c|c|c|c|c|c|c|c|c|c|}
\hline \multicolumn{11}{|c|}{ In --> Out, parallel bulk heads FILTER - Run 5} \\
\hline Water & $\begin{array}{c}\text { Total Vol. } \\
\text { Filtered (L) }\end{array}$ & Turbidity (NTU) & $\begin{array}{l}\text { Vol. of Water } \\
\text { Discharged (L) }\end{array}$ & $\begin{array}{c}\text { Volume of } \\
\text { Water }(\mathrm{mL})\end{array}$ & Time $(\mathrm{sec})$ & Time (min) & $\begin{array}{c}\text { Flowrate } \\
\text { (L/sec) }\end{array}$ & $\begin{array}{l}\text { Flowrate } \\
(\mathrm{mL} / \mathrm{min})\end{array}$ & Ho (inch) & $\mathrm{Hn}$ (inch) \\
\hline \multirow[t]{5}{*}{ Raw Water } & 0 & 394 & 0 & 0 & 0 & 0 & \#DIV/O! & 0 & & 38.00 \\
\hline & 2 & 0.70 & 2 & 2000 & 118 & 1.967 & 0.01695 & 1016.95 & 38.00 & 34.00 \\
\hline & 4 & 0.59 & 2 & 2000 & 119 & 1.983 & 0.01681 & 1008.40 & 34.00 & 30.00 \\
\hline & 6 & 0.38 & 2 & 2000 & 138 & 2.300 & 0.01449 & 869.57 & 30.00 & 26.50 \\
\hline & 6.2 & 0.40 & 0.20 & 200 & 154 & 2.567 & 0.00130 & 77.92 & 26.50 & 25.00 \\
\hline Notes: & & & & & & & & & & \\
\hline
\end{tabular}

\begin{tabular}{|c|c|c|c|c|c|c|c|c|c|c|}
\hline \multicolumn{11}{|c|}{ In --> Out, parallel bulk heads FILTER - Run 6} \\
\hline Water & $\begin{array}{l}\text { Total Vol. } \\
\text { Filtered (L) }\end{array}$ & Turbidity (NTU) & $\begin{array}{l}\text { Vol. of Water } \\
\text { Discharged (L) }\end{array}$ & $\begin{array}{l}\text { Volume of } \\
\text { Water }(\mathrm{mL})\end{array}$ & Time (sec) & Time (min) & $\begin{array}{c}\text { Flowrate } \\
\text { (L/sec) }\end{array}$ & $\begin{array}{l}\text { Flowrate } \\
(\mathrm{mL} / \mathrm{min})\end{array}$ & Ho (inch) & Hn (inch) \\
\hline \multirow[t]{5}{*}{ Raw Water } & 0 & 447 & 0 & 0 & 0 & 0 & \#DIV/0! & 0 & & 38.00 \\
\hline & 2 & 0.75 & 2 & 2000 & 122 & 2.033 & 0.01639 & 983.61 & 38.00 & 35.00 \\
\hline & 4 & 0.58 & 2 & 2000 & 120 & 2.000 & 0.01667 & 1000.00 & 35.00 & 31.00 \\
\hline & 6 & 0.39 & 2 & 2000 & 129 & 2.150 & 0.01550 & 930.23 & 31.00 & 29.00 \\
\hline & 8 & 0.37 & 2 & 2000 & 198 & 3.300 & 0.01010 & 606.06 & 29.00 & 26.00 \\
\hline Notes: & & & & & & & & & & \\
\hline
\end{tabular}

\begin{tabular}{|c|c|c|c|c|c|c|c|c|c|c|}
\hline \multicolumn{11}{|c|}{ In --> Out, parallel bulk heads FILTER - Run 7} \\
\hline Water & $\begin{array}{c}\text { Total Vol. } \\
\text { Filtered (L) }\end{array}$ & Turbidity (NTU) & $\begin{array}{l}\text { Vol. of Water } \\
\text { Discharged (L) }\end{array}$ & $\begin{array}{l}\text { Volume of } \\
\text { Water }(\mathrm{mL})\end{array}$ & Time $(\mathrm{sec})$ & Time $(\min )$ & $\begin{array}{c}\text { Flowrate } \\
\text { (L/sec) }\end{array}$ & $\begin{array}{l}\text { Flowrate } \\
\text { ( } \mathrm{mL} / \mathrm{min})\end{array}$ & Ho (inch) & Hn (inch) \\
\hline \multirow[t]{5}{*}{ Raw Water } & 0 & 423 & 0 & 0 & 0 & 0 & \#DIV/O! & 0 & & 37.50 \\
\hline & 2 & 0.45 & 2 & 2000 & 95 & 1.583 & 0.02105 & 1263.16 & 37.50 & 36.00 \\
\hline & 4 & 0.27 & 2 & 2000 & 110 & 1.833 & 0.01818 & 1090.91 & 36.00 & 32.00 \\
\hline & 6 & 0.34 & 2 & 2000 & 130 & 2.167 & 0.01538 & 923.08 & 32.00 & 29.00 \\
\hline & 8 & 0.41 & 2 & 2000 & 245 & 4.083 & 0.00816 & 489.80 & 29.00 & 25.00 \\
\hline \multicolumn{11}{|l|}{ Notes: } \\
\hline
\end{tabular}

\begin{tabular}{|c|c|c|c|c|c|c|c|c|c|c|}
\hline \multicolumn{11}{|c|}{ In --> Out, parallel bulk heads FILTER - Run 8} \\
\hline Water & $\begin{array}{c}\text { Total Vol. } \\
\text { Filtered (L) }\end{array}$ & Turbidity (NTU) & $\begin{array}{l}\text { Vol. of Water } \\
\text { Discharged (L) }\end{array}$ & $\begin{array}{c}\text { Volume of } \\
\text { Water }(\mathrm{mL})\end{array}$ & Time (sec) & Time (min) & $\begin{array}{c}\begin{array}{c}\text { Flowrate } \\
\text { (L/sec) }\end{array} \\
\end{array}$ & $\begin{array}{l}\text { Flowrate } \\
\text { (mL/min) }\end{array}$ & Ho (inch) & $\mathrm{Hn}$ (inch) \\
\hline \multirow[t]{6}{*}{ Raw Water } & 0 & 531 & 0 & 0 & 0 & 0 & \#DIV/0! & 0 & & 37.00 \\
\hline & 2 & 0.43 & 2 & 2000 & 150 & 2.500 & 0.01333 & 800.00 & 37.00 & 35.25 \\
\hline & 4 & 0.48 & 2 & 2000 & 127 & 2.117 & 0.01575 & 944.88 & 35.25 & 33.00 \\
\hline & 6 & 0.05 & 2 & 2000 & 147 & 2.450 & 0.01361 & 816.33 & 33.00 & 29.50 \\
\hline & 8 & 0.58 & 2 & 2000 & 186 & 3.100 & 0.01075 & 645.16 & 29.50 & 26.75 \\
\hline & 9 & 0.63 & 1 & 1000 & 107 & 1.783 & 0.00935 & 560.75 & 26.75 & 25.00 \\
\hline Notes: & & & & & & & & & & \\
\hline
\end{tabular}




\begin{tabular}{|c|c|c|c|c|c|c|c|c|c|c|}
\hline \multicolumn{11}{|c|}{ In --> Out, parallel bulk heads FILTER - Run 9} \\
\hline Water & $\begin{array}{l}\text { Total Vol. } \\
\text { Filtered (L) }\end{array}$ & Turbidity (NTU) & $\begin{array}{l}\text { Vol. of Water } \\
\text { Discharged (L) }\end{array}$ & $\begin{array}{l}\text { Volume of } \\
\text { Water }(\mathrm{mL})\end{array}$ & Time (sec) & Time (min) & $\begin{array}{c}\text { Flowrate } \\
\text { (L/sec) }\end{array}$ & $\begin{array}{l}\text { Flowrate } \\
\text { (mL/min) }\end{array}$ & Ho (inch) & Hn (inch) \\
\hline \multirow[t]{6}{*}{ Raw Water } & 0 & 479 & 0 & 0 & 0 & 0 & \#DIV/O! & 0 & & 37.00 \\
\hline & 2 & 0.63 & 2 & 2000 & 131 & 2.183 & 0.01527 & 916.03 & 37.00 & 35.00 \\
\hline & 4 & 0.52 & 2 & 2000 & 111 & 1.850 & 0.01802 & 1081.08 & 35.00 & 32.00 \\
\hline & 6 & 0.53 & 2 & 2000 & 127 & 2.117 & 0.01575 & 944.88 & 32.00 & 30.00 \\
\hline & 8 & 0.36 & 2 & 2000 & 166 & 2.767 & 0.01205 & 722.89 & 30.00 & 28.00 \\
\hline & 9.8 & 0.56 & 1.8 & 1800 & 212 & 3.533 & 0.00849 & 509.43 & 28.00 & 25.00 \\
\hline Notes: & & & & & & & & & & \\
\hline
\end{tabular}

\begin{tabular}{|c|c|c|c|c|c|c|c|c|c|c|}
\hline \multicolumn{11}{|c|}{ In --> Out, parallel bulk heads FILTER - Run 10} \\
\hline Water & $\begin{array}{c}\text { Total Vol. } \\
\text { Filtered (L) }\end{array}$ & Turbidity (NTU) & $\begin{array}{l}\text { Vol. of Water } \\
\text { Discharged (L) }\end{array}$ & $\begin{array}{c}\text { Volume of } \\
\text { Water }(\mathrm{mL})\end{array}$ & Time (sec) & Time $(\mathrm{min})$ & $\begin{array}{c}\text { Flowrate } \\
\text { (L/sec) }\end{array}$ & $\begin{array}{l}\text { Flowrate } \\
\text { (mL/min) }\end{array}$ & Ho (inch) & $\mathrm{Hn}$ (inch) \\
\hline \multirow[t]{6}{*}{ Raw Water } & 0 & 475 & 0 & 0 & 0 & 0 & \#DIV/O! & 0 & & 38.00 \\
\hline & 2 & 0.65 & 2 & 2000 & 138 & 2.300 & 0.01449 & 869.57 & 38.00 & 34.50 \\
\hline & 4 & 0.65 & 2 & 2000 & 111 & 1.850 & 0.01802 & 1081.08 & 34.50 & 32.50 \\
\hline & 6 & 0.58 & 2 & 2000 & 130 & 2.167 & 0.01538 & 923.08 & 32.50 & 30.00 \\
\hline & 8 & 0.57 & 2 & 2000 & 170 & 2.833 & 0.01176 & 705.88 & 30.00 & 27.00 \\
\hline & 9 & 0.61 & 1 & 1000 & 120 & 2.000 & 0.00833 & 500.00 & 27.00 & 25.00 \\
\hline Notes: & & & & & & & & & & \\
\hline
\end{tabular}

\begin{tabular}{|c|c|c|c|c|c|c|c|c|c|c|}
\hline \multicolumn{11}{|c|}{ In --> Out, parallel bulk heads FILTER - Run 11} \\
\hline Water & $\begin{array}{l}\text { Total Vol. } \\
\text { Filtered (L) }\end{array}$ & Turbidity (NTU) & $\begin{array}{l}\text { Vol. of Water } \\
\text { Discharged (L) }\end{array}$ & $\begin{array}{l}\text { Volume of } \\
\text { Water }(\mathrm{mL})\end{array}$ & Time (sec) & Time (min) & $\begin{array}{c}\text { Flowrate } \\
\text { (L/sec) }\end{array}$ & $\begin{array}{l}\text { Flowrate } \\
\text { (mL/min) }\end{array}$ & Ho (inch) & $\mathrm{Hn}$ (inch) \\
\hline \multirow[t]{6}{*}{ Raw Water } & 0 & 479 & 0 & 0 & 0 & 0 & \#DIV/O! & 0 & & 38.00 \\
\hline & 2 & 0.63 & 2 & 2000 & 140 & 2.333 & 0.01429 & 857.14 & 38.00 & 35.00 \\
\hline & 4 & 0.64 & 2 & 2000 & 115 & 1.917 & 0.01739 & 1043.48 & 35.00 & 33.00 \\
\hline & 6 & 0.56 & 2 & 2000 & 145 & 2.417 & 0.01379 & 827.59 & 33.00 & 30.25 \\
\hline & 8 & 0.51 & 2 & 2000 & 180 & 3.000 & 0.01111 & 666.67 & 30.25 & 26.50 \\
\hline & 9 & 0.62 & 1 & 1000 & 100 & 1.667 & 0.01000 & 600.00 & 26.50 & 22.00 \\
\hline Notes: & & & & & & & & & & \\
\hline
\end{tabular}

\begin{tabular}{|c|c|c|c|c|c|c|c|c|c|c|}
\hline \multicolumn{11}{|c|}{ In --> Out, parallel bulk heads FILTER - Run 12} \\
\hline Water & $\begin{array}{l}\text { Total Vol. } \\
\text { Filtered (L) }\end{array}$ & Turbidity (NTU) & $\begin{array}{l}\text { Vol. of Water } \\
\text { Discharged (L) }\end{array}$ & $\begin{array}{l}\text { Volume of } \\
\text { Water }(\mathrm{mL})\end{array}$ & Time (sec) & Time (min) & $\begin{array}{c}\text { Flowrate } \\
\text { (L/sec) }\end{array}$ & $\begin{array}{l}\text { Flowrate } \\
\text { (mL/min) }\end{array}$ & Ho (inch) & $\mathrm{Hn}$ (inch) \\
\hline \multirow[t]{6}{*}{ Raw Water } & 0 & 535 & 0 & 0 & 0 & 0 & \#DIV/O! & 0 & & 37.50 \\
\hline & 2 & 0.71 & 2 & 2000 & 150 & 2.500 & 0.01333 & 800.00 & 37.50 & 35.00 \\
\hline & 4 & 0.68 & 2 & 2000 & 115 & 1.917 & 0.01739 & 1043.48 & 35.00 & 33.25 \\
\hline & 6 & 0.63 & 2 & 2000 & 120 & 2.000 & 0.01667 & 1000.00 & 33.25 & 31.25 \\
\hline & 8 & 0.84 & 2 & 2000 & 143 & 2.383 & 0.01399 & 839.16 & 31.25 & 28.00 \\
\hline & 9.25 & 0.64 & 1.25 & 1250 & 120 & 2.000 & 0.01042 & 625.00 & 28.00 & 25.00 \\
\hline
\end{tabular}

\section{EXPERIMENT C-2-Filter \#1}

\begin{tabular}{|c|c|c|c|c|c|c|c|c|c|c|}
\hline \multicolumn{11}{|c|}{ In --> Out, McMaster Carr bulk heads FILTER 1 - Run 1} \\
\hline Water & $\begin{array}{l}\text { Total Vol. } \\
\text { Filtered (L) }\end{array}$ & Turbidity (NTU) & $\begin{array}{l}\text { Vol. of Water } \\
\text { Discharged (L) }\end{array}$ & $\begin{array}{l}\text { Volume of } \\
\text { Water }(\mathrm{mL})\end{array}$ & Time (sec) & Time $(\mathrm{min})$ & $\begin{array}{c}\text { Flowrate } \\
\text { (L/sec) }\end{array}$ & $\begin{array}{l}\text { Flowrate } \\
(\mathrm{mL} / \mathrm{min})\end{array}$ & Ho (inch) & Hn (inch) \\
\hline \multirow[t]{6}{*}{ Raw Water } & 0 & & 0 & 0 & 0 & 0 & \#DIV/O! & 0 & & 33.50 \\
\hline & 2 & & 2 & 2000 & 168 & 2.800 & 0.01190 & 714.29 & 33.50 & 30.00 \\
\hline & 4 & & 2 & 2000 & 123 & 2.050 & 0.01626 & 975.61 & 30.00 & 27.50 \\
\hline & 6 & & 2 & 2000 & 112 & 1.867 & 0.01786 & 1071.43 & 27.50 & 23.50 \\
\hline & 8 & & 2 & 2000 & 173 & 2.883 & 0.01156 & 693.64 & 23.50 & 19.00 \\
\hline & 8.5 & & 0.5 & 500 & 49 & 0.817 & 0.01020 & 612.24 & 19.00 & 17.50 \\
\hline Notes: & & & & & & & & & & \\
\hline
\end{tabular}




\begin{tabular}{|c|c|c|c|c|c|c|c|c|c|c|}
\hline \multicolumn{11}{|c|}{ In --> Out, McMaster Carr bulk heads FILTER 1 - Run 2} \\
\hline Water & $\begin{array}{l}\text { Total Vol. } \\
\text { Filtered (L) }\end{array}$ & Turbidity (NTU) & $\begin{array}{l}\text { Vol. of Water } \\
\text { Discharged (L) }\end{array}$ & $\begin{array}{c}\text { Volume of } \\
\text { Water }(\mathrm{mL})\end{array}$ & Time (sec) & Time $(\min )$ & $\begin{array}{c}\text { Flowrate } \\
\text { (L/sec) }\end{array}$ & $\begin{array}{l}\text { Flowrate } \\
(\mathrm{mL} / \mathrm{min})\end{array}$ & Ho (inch) & $\mathrm{Hn}$ (inch) \\
\hline \multirow[t]{6}{*}{ Raw Water } & 0 & & 0 & 0 & 0 & 0 & \#DIV/O! & 0 & & 33.00 \\
\hline & 2 & & 2 & 2000 & 99 & 1.650 & 0.02020 & 1212.12 & 33.00 & 31.00 \\
\hline & 4 & & 2 & 2000 & 108 & 1.800 & 0.01852 & 1111.11 & 31.00 & 27.75 \\
\hline & 6 & & 2 & 2000 & 110 & 1.833 & 0.01818 & 1090.91 & 27.75 & 24.00 \\
\hline & 8 & & 2 & 2000 & 176 & 2.933 & 0.01136 & 681.82 & 24.00 & 19.25 \\
\hline & 9 & & 1 & 1000 & 120 & 2.000 & 0.00833 & 500.00 & 19.25 & 16.25 \\
\hline
\end{tabular}

Notes: let filter bag fill with water, closed clamp a $1 / 2$ turn before 2 nd draw out of bag to reduce flow rate

\section{EXPERIMENT C-2: Filter \#2}

\begin{tabular}{|c|c|c|c|c|c|c|c|c|c|c|}
\hline \multicolumn{11}{|c|}{ In --> Out, McMaster Carr bulk heads FILTER 2 - Run 1} \\
\hline Water & $\begin{array}{l}\text { Total Vol. } \\
\text { Filtered (L) }\end{array}$ & Turbidity (NTU) & $\begin{array}{l}\text { Vol. of Water } \\
\text { Discharged (L) }\end{array}$ & $\begin{array}{l}\text { Volume of } \\
\text { Water }(\mathrm{mL})\end{array}$ & Time $(\mathrm{sec})$ & Time $(\mathrm{min})$ & $\begin{array}{c}\text { Flowrate } \\
\text { (L/sec) }\end{array}$ & $\begin{array}{l}\text { Flowrate } \\
\text { (mL/min) }\end{array}$ & Ho (inch) & $\mathrm{Hn}$ (inch) \\
\hline \multirow[t]{5}{*}{ Raw Water } & 0 & & 0 & 0 & 0 & 0 & \#DIV/0! & 0 & & 36.50 \\
\hline & 2 & & 2 & 2000 & 124 & 2.067 & 0.01613 & 967.74 & 36.50 & 34.00 \\
\hline & 4 & & 2 & 2000 & 120 & 2.000 & 0.01667 & 1000.00 & 34.00 & 30.50 \\
\hline & 6 & & 2 & 2000 & 134 & 2.233 & 0.01493 & 895.52 & 30.50 & 28.00 \\
\hline & 8 & & 2 & 2000 & 259 & 4.317 & 0.00772 & 463.32 & 28.00 & 26.00 \\
\hline
\end{tabular}

\section{EXPERIMENT C-2: Filter \#3}

\begin{tabular}{|c|c|c|c|c|c|c|c|c|c|c|}
\hline \multicolumn{11}{|c|}{ In --> Out McMaster Carr Bulkheads FILTER 3 (Bag 1) - Run 1} \\
\hline \multicolumn{11}{|c|}{ PUR Serial \#: $0015032231 \quad$ Mfg. 1/10 Exp: $12 / 12$} \\
\hline \multicolumn{11}{|c|}{ Recipe: Chilledtap, dust, I.O., humic, pH adjustment, and spheres } \\
\hline \multicolumn{11}{|c|}{ pH: $9.08 \quad$ Temp: $7^{\circ} \mathrm{C}$} \\
\hline Water & $\begin{array}{c}\text { Total Vol. } \\
\text { Filtered (L) }\end{array}$ & Turbidity (NTU) & $\begin{array}{l}\text { Vol. of Water } \\
\text { Discharged (L) }\end{array}$ & $\begin{array}{l}\text { Volume of } \\
\text { Water }(\mathrm{mL})\end{array}$ & Time (sec) & Time $(\mathrm{min})$ & $\begin{array}{c}\text { Flowrate } \\
\text { (L/sec) }\end{array}$ & $\begin{array}{l}\text { Flowrate } \\
\text { (mL/min) }\end{array}$ & Ho (inch) & Hn (inch) \\
\hline Raw Water & 0 & 491 & 0 & 0 & 0 & 0 & \#DIV/O! & 0 & & 31.50 \\
\hline \multirow[t]{4}{*}{ Pre-Filter } & 0 & 5 & 0 & 0 & 0 & of & \#DIV/O! & 0 & & 31.50 \\
\hline & 2 & 4.89 & 2 & 2000 & 164 & 2.733 & 0.01220 & 731.71 & 31.50 & 28.50 \\
\hline & 4 & 4.22 & 2 & 2000 & 200 & 3.333 & 0.01000 & 600.00 & 28.50 & 26.00 \\
\hline & 6 & 4.37 & 2 & 2000 & 175 & 2.917 & 0.01143 & 685.71 & 26.00 & 21.50 \\
\hline
\end{tabular}

\section{EXPERIMENT C-2: Filter \#4}

\begin{tabular}{|c|c|c|c|c|c|c|c|c|c|c|}
\hline \multicolumn{11}{|c|}{ In --> Out McMaster Carr Bulkheads FILTER 4 (Bag 2) - Run 1} \\
\hline PUR Serial & \#: 001503223 & 1 Mfg. 1/10 & Exp: 12/12 & & & & & & & \\
\hline \multicolumn{11}{|c|}{ Recipe: Chilledtap, dust, I.O., humic, pH adjustment, and spheres } \\
\hline \multicolumn{11}{|c|}{$\mathrm{pH}: 7.02$ Temp: $9^{\circ} \mathrm{C}$} \\
\hline Water & \begin{tabular}{|c|c|} 
Total Vol. \\
Filtered (L)
\end{tabular} & Turbidity (NTU) & $\begin{array}{l}\text { Vol. of Water } \\
\text { Discharged (L) } \\
\end{array}$ & $\begin{array}{c}\text { Volume of } \\
\text { Water }(\mathrm{mL})\end{array}$ & Time (sec) & Time $(\mathrm{min})$ & $\begin{array}{c}\begin{array}{c}\text { Flowrate } \\
(\mathrm{L} / \mathrm{sec})\end{array} \\
\end{array}$ & $\begin{array}{l}\begin{array}{l}\text { Flowrate } \\
(\mathrm{mL} / \mathrm{min})\end{array} \\
\end{array}$ & Ho (inch) & Hn (inch) \\
\hline Raw Water & 0 & 434 & 0 & 0 & 0 & 0 & \#DIV/O! & 0 & & 29.50 \\
\hline \multirow[t]{3}{*}{ Pre-Filter } & 0 & 6.98 & 0 & 0 & 0 & 0 & \#DIV/O! & 0 & & 29.50 \\
\hline & 2 & 3.31 & 2 & 2000 & 200 & 3.333 & 0.01000 & 600.00 & 29.50 & 27.00 \\
\hline & 4 & 3.00 & 2 & 2000 & 284 & 4.733 & 0.00704 & 422.54 & 27.00 & 24.00 \\
\hline
\end{tabular}




\section{EXPERIMENT C-2: Filter \#5}

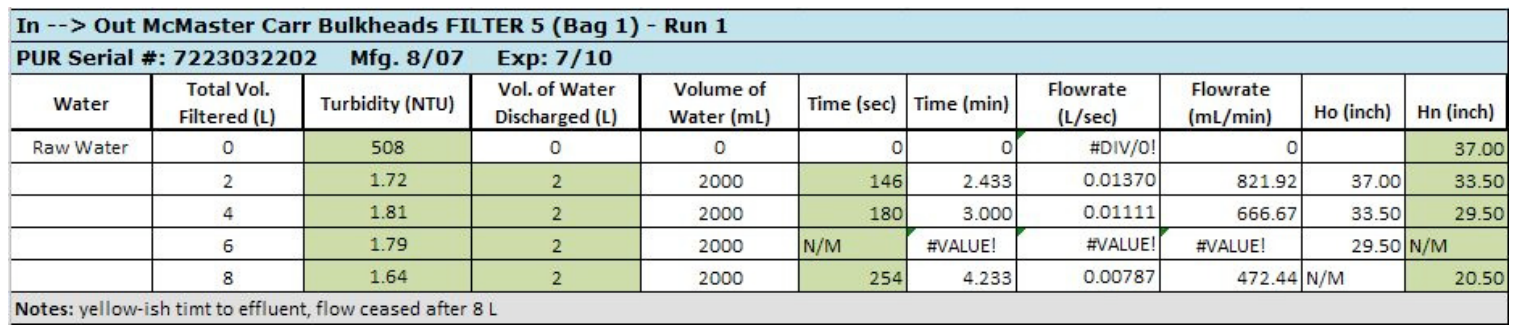

\begin{tabular}{|c|c|c|c|c|c|c|c|c|c|c|}
\hline \multicolumn{11}{|c|}{ In $-->$ Out McMaster Carr Bulkheads FILTER 5 (Bag 1) - Run 2} \\
\hline \multicolumn{3}{|c|}{ PUR Serial \#: 7223032202 Mfg. 8/07 } & \multicolumn{8}{|c|}{ Exp: $7 / 10$} \\
\hline Water & $\begin{array}{l}\text { Total Vol. } \\
\text { Filtered (L) }\end{array}$ & Turbidity (NTU) & $\begin{array}{l}\text { Vol. of Water } \\
\text { Discharged (L) }\end{array}$ & $\begin{array}{l}\text { Volume of } \\
\text { Water }(\mathrm{mL})\end{array}$ & Time $(\mathrm{sec})$ & Time $(\mathrm{min})$ & $\begin{array}{c}\text { Flowrate } \\
\text { (L/sec) }\end{array}$ & $\begin{array}{l}\text { Flowrate } \\
\text { (mL/min) }\end{array}$ & Ho (inch) & $\mathrm{Hn}$ (inch) \\
\hline \multirow[t]{6}{*}{ Raw Water } & 0 & 464 & 0 & 0 & 0 & 0 & \#DIV/O! & 0 & & 37.00 \\
\hline & 2 & 2.97 & 2 & 2000 & 96 & 1.600 & 0.02083 & 1250.00 & 37.00 & 33.50 \\
\hline & 4 & 2.98 & 2 & 2000 & 93 & 1.550 & 0.02151 & 1290.32 & 33.50 & 30.50 \\
\hline & 6 & 2.66 & 2 & 2000 & 155 & 2.583 & 0.01290 & 774.19 & 30.50 & 27.00 \\
\hline & 8 & 2.53 & 2 & 2000 & 125 & 2.083 & 0.01600 & 960.00 & 27.00 & 24.00 \\
\hline & 8.8 & 2.58 & 0.8 & 800 & 61 & 1.017 & 0.01311 & 786.89 & 24.00 & 21.25 \\
\hline
\end{tabular}

\begin{tabular}{|c|c|c|c|c|c|c|c|c|c|c|}
\hline \multicolumn{11}{|c|}{ In --> Out McMaster Carr Bulkheads FILTER 5 (Bag 1) - Run 3} \\
\hline \multicolumn{11}{|c|}{ PUR Serial \#: 7223032202 Mfg. 8/07 Exp: 7/10 } \\
\hline Water & $\begin{array}{c}\text { Total Vol. } \\
\text { Filtered (L) }\end{array}$ & Turbidity (NTU) & $\begin{array}{l}\text { Vol. of Water } \\
\text { Discharged (L) }\end{array}$ & $\begin{array}{c}\text { Volume of } \\
\text { Water }(\mathrm{mL})\end{array}$ & Time $(\mathrm{sec})$ & Time (min) & $\begin{array}{c}\text { Flowrate } \\
\text { (L/sec) }\end{array}$ & $\begin{array}{l}\text { Flowrate } \\
(\mathrm{mL} / \mathrm{min})\end{array}$ & Ho (inch) & Hn (inch) \\
\hline \multirow[t]{5}{*}{ Raw Water } & 0 & 430 & 0 & 0 & 0 & 0 & \#DIV/O! & 0 & & 35.00 \\
\hline & 2 & 1.95 & 2 & 2000 & 98 & 1.633 & 0.02041 & 1224.49 & 35.00 & 32.50 \\
\hline & 4 & 3.25 & 2 & 2000 & 106 & 1.767 & 0.01887 & 1132.08 & 32.50 & 31.00 \\
\hline & 6 & 1.89 & 2 & 2000 & 123 & 2.050 & 0.01626 & 975.61 & 31.00 & 26.50 \\
\hline & 7.8 & 1.92 & 1.8 & 1800 & 172 & 2.867 & 0.01047 & 627.91 & 26.50 & 20.00 \\
\hline
\end{tabular}

\section{EXPERIMENT C-2: Filter \#6}

\begin{tabular}{|c|c|c|c|c|c|c|c|c|c|c|}
\hline \multicolumn{11}{|c|}{ In --> Out McMaster Carr Bulkheads FILTER 6 (Bag 2) - Run 1} \\
\hline \multicolumn{3}{|c|}{ PUR Serial \#: 7223032202 Mfg. 8/07 } & \multicolumn{8}{|c|}{ Exp: $7 / 10$} \\
\hline Water & $\begin{array}{l}\text { Total Vol. } \\
\text { Filtered (L) }\end{array}$ & Turbidity (NTU) & $\begin{array}{l}\text { Vol. of Water } \\
\text { Discharged (L) }\end{array}$ & $\begin{array}{l}\text { Volume of } \\
\text { Water }(\mathrm{mL})\end{array}$ & Time $(\mathrm{sec})$ & Time $(\mathrm{min})$ & $\begin{array}{c}\text { Flowrate } \\
\text { (L/sec) }\end{array}$ & $\begin{array}{l}\text { Flowrate } \\
\text { (mL/min) }\end{array}$ & Ho (inch) & Hn (inch) \\
\hline \multirow[t]{5}{*}{ Raw Water } & 0 & 476 & 0 & 0 & 0 & 0 & \#DIV/0! & 0 & & 35.00 \\
\hline & 2 & 2.51 & 2 & 2000 & 102 & 1.700 & 0.01961 & 1176.47 & 35.00 & 32.50 \\
\hline & 4 & 2.62 & 2 & 2000 & 80 & 1.333 & 0.02500 & 1500.00 & 32.50 & 29.50 \\
\hline & 6 & 2.58 & 2 & 2000 & 120 & 2.000 & 0.01667 & 1000.00 & 29.50 & 25.50 \\
\hline & 8 & 2.59 & 2 & 2000 & 103 & 1.717 & 0.01942 & 1165.05 & 25.50 & 21.00 \\
\hline
\end{tabular}

\begin{tabular}{|c|c|c|c|c|c|c|c|c|c|c|}
\hline \multicolumn{11}{|c|}{ In --> Out McMaster Carr Bulkheads FILTER 6 (Bag 2) - Run 2} \\
\hline \multicolumn{11}{|c|}{ PUR Serial \#: $7223032202 \quad$ Mfg. 8/07 $\quad$ Exp: 7/10 } \\
\hline Water & $\begin{array}{l}\text { Total Vol. } \\
\text { Filtered (L) }\end{array}$ & Turbidity (NTU) & $\begin{array}{l}\text { Vol. of Water } \\
\text { Discharged (L) }\end{array}$ & $\begin{array}{l}\text { Volume of } \\
\text { Water }(\mathrm{mL})\end{array}$ & Time (sec) & Time $(\min )$ & $\begin{array}{c}\text { Flowrate } \\
\text { (L/sec) }\end{array}$ & $\begin{array}{l}\text { Flowrate } \\
\text { (mL/min) }\end{array}$ & Ho (inch) & Hn (inch) \\
\hline \multirow[t]{5}{*}{ Raw Water } & 0 & 464 & 0 & 0 & 0 & 0 & \#DIV/O! & 0 & & 36.25 \\
\hline & 2 & 2.21 & 2 & 2000 & 93 & 1.550 & 0.02151 & 1290.32 & 36.25 & 34.50 \\
\hline & 4 & 2.29 & 2 & 2000 & 78 & 1.300 & 0.02564 & 1538.46 & 34.50 & 29.25 \\
\hline & 6 & 2.31 & 2 & 2000 & 103 & 1.717 & 0.01942 & 1165.05 & 29.25 & 26.00 \\
\hline & 8 & 2.19 & 2 & 2000 & 99 & 1.650 & 0.02020 & 1212.12 & 26.00 & 21.50 \\
\hline
\end{tabular}




\begin{tabular}{|c|c|c|c|c|c|c|c|c|c|c|}
\hline \multicolumn{11}{|c|}{ In --> Out McMaster Carr Bulkheads FILTER 6 (Bag 2) - Run 3} \\
\hline \multicolumn{3}{|c|}{ PUR Serial \#: 7223032202 Mfg. 8/07 } & \multicolumn{8}{|l|}{ Exp: 7/10 } \\
\hline Water & $\begin{array}{c}\text { Total Vol. } \\
\text { Filtered (L) } \\
\end{array}$ & Turbidity (NTU) & $\begin{array}{l}\text { Vol. of Water } \\
\text { Discharged (L) }\end{array}$ & $\begin{array}{c}\text { Volume of } \\
\text { Water }(\mathrm{mL})\end{array}$ & Time (sec) & Time $(\min )$ & $\begin{array}{c}\text { Flowrate } \\
(\mathrm{L} / \mathrm{sec})\end{array}$ & $\begin{array}{l}\text { Flowrate } \\
(\mathrm{mL} / \mathrm{min})\end{array}$ & Ho (inch) & Hn (inch) \\
\hline \multirow[t]{5}{*}{ Raw Water } & 0 & 430 & 0 & 0 & 0 & of & \#DIV/0! & 0 & & 35.00 \\
\hline & 2 & 1.99 & 2 & 2000 & 94 & 1.567 & 0.02128 & 1276.60 & 35.00 & 33.00 \\
\hline & 4 & 2.12 & 2 & 2000 & 130 & 2.167 & 0.01538 & 923.08 & 33.00 & 30.50 \\
\hline & 6 & 1.94 & 2 & 2000 & 125 & 2.083 & 0.01600 & 960.00 & 30.50 & 26.50 \\
\hline & 8 & 2.06 & 2 & 2000 & 125 & 2.083 & 0.01600 & 960.00 & 26.50 & 22.00 \\
\hline
\end{tabular}

\section{EXPERIMENT E-1}

In --> Out McMaster Carr Bulkheads FILTER (Bag 1) - Run 1 PUR Serial \#: 0015032231 Mfg. 1/10 Exp: 12/12

\begin{tabular}{|c|c|c|c|c|c|c|c|c|c|c|c|}
\hline Water & $\begin{array}{l}\text { Total Vol. } \\
\text { Filtered (L) }\end{array}$ & $\begin{array}{l}\text { Turbidity } \\
\text { (NTU) }\end{array}$ & $\begin{array}{l}\text { Vol. of Water } \\
\text { Discharged (L) }\end{array}$ & $\begin{array}{l}\text { Volume of } \\
\text { Water }(\mathrm{mL})\end{array}$ & Time (sec) & Time $(\mathrm{min})$ & $\begin{array}{l}\text { Flowrate } \\
\text { (L/sec) }\end{array}$ & $\begin{array}{l}\text { Flowrate } \\
(\mathrm{mL} / \mathrm{min})\end{array}$ & Ho (inch) & $\mathrm{Hn}$ (inch) & Cyst Count \\
\hline \multirow[t]{5}{*}{ Raw Water } & 0 & 499 & 0 & 0 & 0 & 0 & \#DIV/O! & 0 & & 39.00 & TNTC \\
\hline & 2 & 4.36 & 2 & 2000 & 100 & 1.667 & 0.02000 & 1200.00 & 39.00 & 35.00 & \\
\hline & 4 & 4.42 & 2 & 2000 & 93 & 1.550 & 0.02151 & 1290.32 & 35.00 & 30.75 & 440 \\
\hline & 6 & 4.05 & 2 & 2000 & 114 & 1.900 & 0.01754 & 1052.63 & 30.75 & 27.00 & \\
\hline & 8 & 3.91 & 2 & 2000 & 121 & 2.017 & 0.01653 & 991.74 & 27.00 & 23.50 & \\
\hline
\end{tabular}

\section{EXPERIMENT F-1}

\begin{tabular}{|c|c|c|c|c|c|c|c|c|c|c|}
\hline \multicolumn{11}{|c|}{ In --> Out 1 Ply Absolute FILTER - Run 1} \\
\hline PUR Serial & 00150322 & I Mfg. 1/10 & Exp: $12 / 12$ & & & & & & & \\
\hline \multicolumn{11}{|c|}{ Recipe: tap water, dust, I.O., humic, and spheres ( 15 L made) } \\
\hline Water & $\begin{array}{c}\text { Total Vol. } \\
\text { Filtered (L) }\end{array}$ & Turbidity (NTU) & $\begin{array}{l}\text { Vol. of Water } \\
\text { Discharged (L) }\end{array}$ & $\begin{array}{c}\begin{array}{c}\text { Volume of } \\
\text { Water }(\mathrm{mL})\end{array} \\
\end{array}$ & Time $(\mathrm{sec})$ & Time $(\min )$ & $\begin{array}{c}\text { Flowrate } \\
\text { (L/sec) }\end{array}$ & $\begin{array}{l}\text { Flowrate } \\
(\mathrm{mL} / \mathrm{min})\end{array}$ & Ho (inch) & Hn (inch) \\
\hline \multirow[t]{3}{*}{ Raw Water } & 0 & 53.9 & 0 & 0 & 0 & of & \#DIV/O! & 0 & & 37.50 \\
\hline & 2 & 1.90 & 2 & 2000 & 1560 & 26 & 0.00128 & 76.92 & 37.50 & 35.00 \\
\hline & 3.15 & 1.63 & 1.15 & 1150 & 1200 & 20 & 0.00096 & 57.50 & 35.00 & 33.50 \\
\hline
\end{tabular}

Notes: during $2 \mathrm{~L}$ pull: red-tab valve closed after $2 \mathrm{~min}$. b/c flow too slow, filter needed to wet and water needed to build up in the filter pouch for flow, had to open both red-tab valves all the way.

\begin{tabular}{|c|c|c|c|c|c|c|c|c|c|c|c|}
\hline \multicolumn{12}{|c|}{ PUR Serial \#: 0015032231} \\
\hline \multicolumn{12}{|c|}{ Recipe: tap water, dust, I.o., humic, and spheres ( $15 \mathrm{~L}$ made) } \\
\hline Water & $\begin{array}{l}\text { Total Vol. } \\
\text { Filtered (L) }\end{array}$ & $\begin{array}{c}\text { Turbidity } \\
\text { (NTU) }\end{array}$ & $\begin{array}{l}\text { Vol. of Water } \\
\text { Discharged (L) }\end{array}$ & $\begin{array}{l}\text { Volume of } \\
\text { Water }(\mathrm{mL})\end{array}$ & Time $(\mathrm{sec})$ & Time (min) & $\begin{array}{c}\text { Flowrate } \\
\text { (L/sec) }\end{array}$ & $\begin{array}{l}\text { Flowrate } \\
\text { (mL/min) }\end{array}$ & Ho (inch) & Hn (inch) & Cyst Count \\
\hline \multirow[t]{3}{*}{ Raw Water } & 0 & 58.1 & 0 & 0 & 0 & 0 & \#DIV/O! & 0 & & $\mathrm{~N} / \mathrm{M}$ & TNTC \\
\hline & 2 & 2.44 & 2 & 2000 & 591 & 9.850 & 0.00338 & 203.05 & TNTC & 62.00 & \\
\hline & 4 & 1.77 & 2 & 2000 & 1590 & 26.500 & 0.00126 & 75.47 & 0.00 & 59.50 & 162.00 \\
\hline
\end{tabular}




\section{EXPERIMENT F-3}

\begin{tabular}{|c|c|c|c|c|c|c|c|c|c|c|c|}
\hline \multicolumn{12}{|c|}{ In --> Out 2 Ply Nominal inside Absolute FILTER } \\
\hline \multicolumn{12}{|c|}{ Recipe: tap water (for flow curve) } \\
\hline Water & $\begin{array}{l}\text { Total Vol. } \\
\text { Filtered (L) }\end{array}$ & $\begin{array}{c}\text { Turbidity } \\
\text { (NTU) }\end{array}$ & $\begin{array}{l}\text { Vol. of Water } \\
\text { Discharged (L) }\end{array}$ & $\begin{array}{l}\text { Volume of } \\
\text { Water }(\mathrm{mL})\end{array}$ & Time (sec) & Time $(\min )$ & $\begin{array}{c}\text { Flowrate } \\
(\mathrm{L} / \mathrm{sec})\end{array}$ & $\begin{array}{l}\text { Flowrate } \\
\text { (mL/min) }\end{array}$ & Ho (inch) & $\mathrm{Hn}$ (inch) & Cyst Count \\
\hline \multirow[t]{6}{*}{ Raw Water } & 0 & & 0 & 0 & 0 & of & \#DIV/O! & 0 & & 64.00 & \\
\hline & 2 & & 2 & 2000 & 163 & 2.717 & 0.01227 & 736.20 & 64.00 & 60.75 & \\
\hline & 4 & & 2 & 2000 & 119 & 1.983 & 0.01681 & 1008.40 & & 58.00 & \\
\hline & 6 & & 2 & 2000 & 129 & 2.150 & 0.01550 & 930.23 & & 53.50 & \\
\hline & 8 & & 2 & 2000 & 138 & 2.300 & 0.01449 & 869.57 & & 49.00 & \\
\hline & 8.925 & & 0.925 & 925 & 79 & 1.317 & 0.01171 & 702.53 & 60.75 & 49.00 & \\
\hline
\end{tabular}

\begin{tabular}{|c|c|c|c|c|c|c|c|c|c|c|c|c|}
\hline \multicolumn{13}{|c|}{ In --> Out 2 Ply Nominal inside Absolute FILTER - Run 1} \\
\hline PUR Serial & 00150322 & Mfg. & 10 & Exp: 12 & & & & & & & & \\
\hline \multicolumn{13}{|c|}{ Recipe: tap water, dust, I.O., humic, and spheres ( $15 \mathrm{~L}$ made) } \\
\hline Water & $\begin{array}{l}\text { Total Vol. } \\
\text { Filtered (L) }\end{array}$ & $\begin{array}{c}\text { Turbidity } \\
\text { (NTU) }\end{array}$ & & $\begin{array}{l}\text { of Water } \\
\text { harged (L) }\end{array}$ & $\begin{array}{c}\text { Volume of } \\
\text { Water }(\mathrm{mL})\end{array}$ & Time (sec) & Time $(\mathrm{min})$ & $\begin{array}{c}\text { Flowrate } \\
(\mathrm{L} / \mathrm{sec})\end{array}$ & $\begin{array}{l}\text { Flowrate } \\
(\mathrm{mL} / \mathrm{min})\end{array}$ & Ho (inch) & $\mathrm{Hn}$ (inch) & Cyst Count \\
\hline \multirow[t]{5}{*}{ Raw Water } & 0 & 59 & & 0 & 0 & 0 & of & \#DIV/0! & 0 & & 65.50 & TNTC \\
\hline & 2 & 2.24 & & 2 & 2000 & 174 & 2.900 & 0.01149 & 689.66 & 65.50 & 63.00 & \\
\hline & 4 & 2.04 & & 2 & 2000 & 173 & 2.883 & 0.01156 & 693.64 & 63.00 & 60.75 & 54 \\
\hline & 6 & 1.82 & & 2 & 2000 & 323 & 5.383 & 0.00619 & 371.52 & 60.75 & 58.25 & \\
\hline & 8 & 1.37 & & 2 & 2000 & 1029 & 17.150 & 0.00194 & 116.62 & 58.25 & 54.00 & \\
\hline
\end{tabular}

\section{EXPERIMENT G-1}

In $-\rightarrow$ Out 2 Ply Nominal Filter, 5 Min. Mix - Run 1 PUR Serial \#: $0015032231 \quad$ Mfg. 1/10 Exp: 12/12 Recipe: tap water, dust, I.0., humic, and spheres (70 L made in trash can with sump pump)

\begin{tabular}{|c|c|c|c|c|c|c|c|c|c|c|c|}
\hline Water & $\begin{array}{l}\text { Total Vol. } \\
\text { Filtered (L) }\end{array}$ & Turbidity (NTU) & $\begin{array}{l}\text { Vol. of Water } \\
\text { Discharged (L) }\end{array}$ & $\begin{array}{l}\text { Volume of } \\
\text { Water }(\mathrm{mL})\end{array}$ & Time (sec) & Time $(\mathrm{min})$ & $\begin{array}{c}\text { Flowrate } \\
\text { [L/sec) }\end{array}$ & $\begin{array}{l}\text { Flowrate } \\
\text { (mL/min) }\end{array}$ & Ho (inch) & Hn (inch) & Cyst Count \\
\hline \multirow[t]{5}{*}{ Raw Water } & 0 & 60.6 & 0 & 0 & 0 & of & \#DIV/O! & 0 & & 37.00 & TNTC \\
\hline & 2 & 5.33 & 2 & 2000 & 211 & 3.517 & 0.00948 & 568.72 & 37.00 & 34.00 & \\
\hline & 4 & 5.77 & 2 & 2000 & 216 & 3.600 & 0.00926 & 555.56 & 34.00 & 30.50 & $>1000$ \\
\hline & 6 & 5.62 & 2 & 2000 & 330 & 5.500 & 0.00606 & 363.64 & 30.50 & 27.00 & \\
\hline & 8 & 4.78 & 2 & 2000 & 564 & 9.400 & 0.00355 & 212.77 & 27.00 & 21.50 & \\
\hline
\end{tabular}

Notes: turbidimeter was correctly calibrated, confirmed with tap water (read $0.72 \mathrm{NTU}$ ), during $6 \mathrm{~L}$ pull the filter plastic suctioned to the filter pouch outlet bulkhead; reduced flow, possible that sump pump heated up water too much; resulting in higher than normal treated water turbidity

In --> Out 2 Ply Nominal Filter, 5 Min. Mix - Run 2

PUR Serial \#: $0015032231 \quad$ Mfg. 1/10 $\quad$ Exp: 12/12

Recipe: tap water, dust, I.0., humic, and spheres (15 L)

\begin{tabular}{|c|c|c|c|c|c|c|c|c|c|c|c|}
\hline Water & $\begin{array}{l}\text { Total Vol. } \\
\text { Filtered (Lᄂ) }\end{array}$ & Turbidity (NTU) & $\begin{array}{l}\text { Vol. of Water } \\
\text { Discharged (Lᄂ) }\end{array}$ & $\begin{array}{l}\text { Volume of } \\
\text { Water }(\mathrm{mL})\end{array}$ & Time (sec) & Time (min) & $\begin{array}{c}\text { Flowrate } \\
(\mathrm{L} / \mathrm{sec})\end{array}$ & $\begin{array}{l}\text { Flowrate } \\
(\mathrm{mL} / \mathrm{min}) \\
\end{array}$ & Ho (inch) & Hn (inch) & Cyst Count \\
\hline \multirow[t]{5}{*}{ Raw Water } & 0 & 46.5 & 0 & 0 & 0 & 의 & \#DIV/0! & 0 & & 37.00 & TNTC \\
\hline & 2 & 3.99 & 2 & 2000 & 163 & 2.717 & 0.01227 & 736.20 & 37.00 & 34.00 & \\
\hline & 4 & 3.79 & 2 & 2000 & 263 & 4.383 & 0.00760 & 456.27 & 34.00 & 30.50 & 170 \\
\hline & 6 & 3.80 & 2 & 2000 & 189 & 3.150 & 0.01058 & 634.92 & 30.50 & 27.00 & \\
\hline & 8 & 3.72 & 2 & 2000 & 240 & 4.000 & 0.00833 & 500.00 & 27.00 & 21.50 & \\
\hline
\end{tabular}


In --> Out 2 Ply Nominal Filter, 5 Min. Mix - Run 3 PUR Serial \#: $0015032231 \quad$ Mfg. 1/10 $\quad$ Exp: 12/12 Recipe: tap water, dust, I.O., humic, and spheres (15 L)

\begin{tabular}{|c|c|c|c|c|c|c|c|c|c|c|c|}
\hline Water & $\begin{array}{l}\text { Total Vol. } \\
\text { Filtered (L) }\end{array}$ & Turbidity (NTU) & $\begin{array}{l}\text { Vol. of Water } \\
\text { Discharged (L) }\end{array}$ & $\begin{array}{l}\text { Volume of } \\
\text { Water }(\mathrm{mL})\end{array}$ & Time $(\mathrm{sec})$ & Time (min) & $\begin{array}{c}\text { Flowrate } \\
\text { (L/sec) }\end{array}$ & $\begin{array}{l}\text { Flowrate } \\
\text { (mL/min) }\end{array}$ & Ho (inch) & $\mathrm{Hn}$ (inch) & Cyst Count \\
\hline \multirow[t]{5}{*}{ Raw Water } & 0 & 47.4 & 0 & 0 & 0 & 이 & $\#$ DIV/O! & 0 & & 39.50 & TNTC \\
\hline & 2 & 2.95 & 2 & 2000 & 232 & 3.867 & 0.00862 & 517.24 & 39.50 & 37.00 & \\
\hline & 4 & 2.72 & 2 & 2000 & 235 & 3.917 & 0.00851 & 510.64 & 37.00 & 35.25 & $>1000$ \\
\hline & 6 & 2.77 & 2 & 2000 & 225 & 3.750 & 0.00889 & 533.33 & 35.25 & 32.50 & \\
\hline & 8 & 2.59 & 2 & 2000 & 260 & 4.333 & 0.00769 & 461.54 & 32.50 & 29.25 & \\
\hline
\end{tabular}

In --> Out 2 Ply Nominal Filter, 5 Min. Mix - Run 4 PUR Serial \#: $0015032231 \quad$ Mfg. 1/10 $\quad$ Exp: 12/12 Recipe: tap water, dust, I.O., humic, and spheres (15 L) Water Temp: N/M

\begin{tabular}{|c|c|c|c|c|c|c|c|c|c|c|c|}
\hline Water & $\begin{array}{l}\text { Total Vol. } \\
\text { Filtered (L) }\end{array}$ & Turbidity (NTU) & $\begin{array}{l}\text { Vol. of Water } \\
\text { Discharged (L) }\end{array}$ & $\begin{array}{l}\text { Volume of } \\
\text { Water }(\mathrm{mL})\end{array}$ & Time $(\mathrm{sec})$ & Time (min) & $\begin{array}{c}\text { Flowrate } \\
\text { (L/sec) }\end{array}$ & $\begin{array}{l}\text { Flowrate } \\
\text { (mL/min) }\end{array}$ & Ho (inch) & Hn (inch) & Cyst Count \\
\hline Raw Water & 0 & 59.3 & 0 & 0 & 0 & 0 & \#DIV/O! & 0 & & 39.00 & TNTC \\
\hline \multirow[t]{2}{*}{ Pre-Filter } & 0 & 6.14 & 0 & & & & & & & & \\
\hline & 2 & 4.86 & 2 & 2000 & 200 & 3.333 & 0.01000 & 600.00 & 39.00 & 35.00 & \\
\hline \multirow[t]{4}{*}{ Pre-Filter } & 4 & 5.39 & & & & & & & & & TNTC \\
\hline & 4 & 4.66 & 2 & 2000 & 185 & 3.083 & 0.01081 & 648.65 & 35.00 & 32.25 & 3121 \\
\hline & 6 & 4.80 & 2 & 2000 & 256 & 4.267 & 0.00781 & 468.75 & 32.25 & 27.75 & \\
\hline & 8 & $\mathrm{~N} / \mathrm{M}$ & 2 & 2000 & 208 & 3.467 & 0.00962 & 576.92 & 27.75 & $\mathrm{~N} / \mathrm{M}$ & \\
\hline
\end{tabular}

In $\rightarrow$ Out 2 Ply Nominal Filter, 5 Min. Mix - Run 5

PUR Serial \#: $0015032231 \quad$ Mfg. 1/10 $\quad$ Exp: 12/12

Recipe: tap water, dust, I.0., humic, and spheres (15 L)

Water Temp: $210 \mathrm{C}$

\begin{tabular}{|c|c|c|c|c|c|c|c|c|c|c|c|}
\hline Water & $\begin{array}{l}\text { Total Vol. } \\
\text { Filtered (L) }\end{array}$ & Turbidity (NTU) & $\begin{array}{l}\text { Vol. of Water } \\
\text { Discharged (L) }\end{array}$ & $\begin{array}{l}\text { Volume of } \\
\text { Water }(\mathrm{mL})\end{array}$ & Time (sec) & Time (min) & $\begin{array}{c}\text { Flowrate } \\
\text { (L/sec) }\end{array}$ & $\begin{array}{l}\text { Flowrate } \\
\text { (mL/min) }\end{array}$ & Ho (inch) & $\mathrm{Hn}$ (inch) & Cyst Count \\
\hline Raw Water & 0 & 46.4 & 0 & 0 & 0 & 0 & \#DIV/0! & 0 & & 37.25 & $\mathrm{~N} / \mathrm{M}$ \\
\hline \multirow[t]{2}{*}{ Pre-Filter } & 0 & $\mathrm{~N} / \mathrm{M}$ & 0 & & & & & & & & \\
\hline & 2 & 2.71 & 2 & 2000 & 225 & 3.750 & 0.00889 & 533.33 & 37.25 & 33.75 & \\
\hline \multirow[t]{4}{*}{ Pre-Filter } & 4 & $\mathrm{~N} / \mathrm{M}$ & & & & & & & & & $\mathrm{N} / \mathrm{M}$ \\
\hline & 4 & 3.17 & 2 & 2000 & 146 & 2.433 & 0.01370 & 821.92 & 33.75 & 30.00 & $\mathrm{~N} / \mathrm{M}$ \\
\hline & 6 & 2.87 & 2 & 2000 & 187 & 3.117 & 0.01070 & 641.71 & 30.00 & 27.50 & \\
\hline & 8 & 2.60 & 2 & 2000 & 260 & 4.333 & 0.00769 & 461.54 & 27.50 & 21.50 & \\
\hline
\end{tabular}

\section{EXPERIMENT G-2}

In --> Out 2 Ply Nominal Filter, 10 Min. Mix - Run 1 PUR Serial \#: 0015032231 Mfg. 1/10 Exp: 12/12 Recipe: tap water, dust, I.0., humic, and spheres (70 L made in trash can with sump pump)

\begin{tabular}{|c|c|c|c|c|c|c|c|c|c|c|c|}
\hline Water & $\begin{array}{l}\text { Total Vol. } \\
\text { Filtered (ㄴ) }\end{array}$ & $\begin{array}{c}\text { Turbidity } \\
\text { (NTU) }\end{array}$ & $\begin{array}{l}\text { Vol. of Water } \\
\text { Discharged (L) }\end{array}$ & $\begin{array}{l}\text { Volume of } \\
\text { Water }(\mathrm{mL})\end{array}$ & Time (sec) & Time (min) & $\begin{array}{c}\text { Flowrate } \\
\text { [L/sec) }\end{array}$ & $\begin{array}{l}\text { Flowrate } \\
(\mathrm{mL} / \mathrm{min})\end{array}$ & Ho (inch) & $\mathrm{Hn}$ (inch) & Cyst Count \\
\hline \multirow[t]{5}{*}{$\begin{array}{c}\text { Raw } \\
\text { Water }\end{array}$} & 0 & 60.6 & 0 & 0 & 0 & 0 & \#DIV $/ 0$ ! & 0 & & 37.50 & TNTC \\
\hline & 2 & 6.24 & 2 & 2000 & 345 & 5.750 & 0.00580 & 347.83 & 37.50 & 35.00 & \\
\hline & 4 & 6.49 & 2 & 2000 & 316 & 5.267 & 0.00633 & 379.75 & 35.00 & 32.50 & 54 \\
\hline & 6 & 6.31 & 2 & 2000 & 308 & 5.133 & 0.00649 & 389.61 & 32.50 & 28.00 & \\
\hline & 8 & 6.06 & 2 & 2000 & 645 & 10.750 & 0.00310 & 186.05 & 28.00 & 24.00 & \\
\hline
\end{tabular}

Notes: turbidimeter was correctly calibrated, confirmed with tap water (read $0.72 \mathrm{NTU}$ ), during $6 \mathrm{~L}$ pull the filter plastic suctioned to the filter pouch outlet bulkhead; reduced flow, possible that sump pump heated up water too much; resulting in higher than normal treated water turbidity 
In --> Out 2 Ply Nominal Filter, 10 Min. Mix - Run 2

PUR Serial \#: 0015032231 Mfg. 1/10 Exp: 12/12

Recipe: tap water, dust, I.O., humic, and spheres (15 L)

\begin{tabular}{|c|c|c|c|r|r|r|r|r|r|r|r|}
\hline Water & $\begin{array}{c}\text { Total Vol. } \\
\text { Filtered (L) }\end{array}$ & $\begin{array}{c}\text { Turbidity } \\
\text { (NTU) }\end{array}$ & $\begin{array}{c}\text { Vol. of Water } \\
\text { Discharged (L) }\end{array}$ & $\begin{array}{c}\text { Volume of } \\
\text { Water (mL) }\end{array}$ & Time (sec) & Time (min) & $\begin{array}{c}\text { Flowrate } \\
\text { (L/sec) }\end{array}$ & $\begin{array}{c}\text { Flowrate } \\
\text { (mL/min) }\end{array}$ & Ho (inch) & Hn (inch) & Cyst Count \\
\hline $\begin{array}{c}\text { Raw } \\
\text { Water }\end{array}$ & 0 & 51.3 & 0 & 0 & 0 & 0 & \#DIV/O! & 0 & & N/M & TNTC \\
\hline & 2 & 4.62 & 2 & 2000 & 298 & 4.967 & 0.00671 & 402.68 & N/M & 35.75 & \\
\hline & 4 & 4.67 & 2 & 2000 & 337 & 5.617 & 0.00593 & 356.08 & 35.75 & 33.25 & $>1000$ \\
\hline & 6 & 4.25 & 2 & 2000 & 174 & 2.900 & 0.01149 & 689.66 & 33.25 & 28.50 & \\
\hline
\end{tabular}

In --> Out 2 Ply Nominal Filter, 10 Min. Mix - Run 3

PUR Serial \#: $0015032231 \quad$ Mfg. 1/10 $\quad$ Exp: 12/12

Recipe: tap water, dust, I.O., humic, and spheres (15 L)

\begin{tabular}{|c|c|c|c|r|r|r|r|r|r|r|r|}
\hline Water & $\begin{array}{c}\text { Total Vol. } \\
\text { Filtered (L) }\end{array}$ & $\begin{array}{c}\text { Turbidity } \\
\text { (NTU) }\end{array}$ & $\begin{array}{c}\text { Vol. of Water } \\
\text { Discharged (L) }\end{array}$ & $\begin{array}{c}\text { Volume of } \\
\text { Water (mL) }\end{array}$ & Time (sec) & Time (min) & $\begin{array}{c}\text { Flowrrate } \\
\text { (L/sec) }\end{array}$ & $\begin{array}{c}\text { Flowrate } \\
\text { (mL/min) }\end{array}$ & Ho (inch) & Hn (inch) & Cyst Count \\
\hline $\begin{array}{c}\text { Raw } \\
\text { Water }\end{array}$ & 0 & 52.8 & 0 & 0 & 0 & 0 & \#DIV/0! & 0 & & 37.50 & TNTC \\
\hline & 2 & 4.02 & 2 & 2000 & 221 & 3.683 & 0.00905 & 542.99 & 37.50 & 36.25 & \\
\hline & 4 & 3.96 & 2 & 2000 & 129 & 2.150 & 0.01550 & 930.23 & 36.25 & 33.00 & $>1000$ \\
\hline & 6 & 3.96 & 2 & 2000 & 175 & 2.917 & 0.01143 & 685.71 & 33.00 & 30.25 & \\
\hline
\end{tabular}

In --> Out 2 Ply Nominal Filter, 10 Min. Mix - Run 4

\begin{tabular}{lll}
\hline PUR Serial \#: 0015032231 & Mfg. 1/10 & Exp: 12/12
\end{tabular}

Recipe: tap water, dust, I.0., humic, and spheres (15 L)

Water Temp: $210 \mathrm{C}$

\begin{tabular}{|c|c|c|c|r|r|r|r|r|r|r|r|}
\hline Water & $\begin{array}{c}\text { Total Vol. } \\
\text { Filtered (L) }\end{array}$ & $\begin{array}{c}\text { Turbidity } \\
\text { (NTU) }\end{array}$ & $\begin{array}{c}\text { Vol. of Water } \\
\text { Discharged (L) }\end{array}$ & $\begin{array}{c}\text { Volume of } \\
\text { Water (mL) }\end{array}$ & Time (sec) & Time (min) & $\begin{array}{c}\text { Flowrate } \\
\text { (L/sec) }\end{array}$ & $\begin{array}{c}\text { Flowrate } \\
\text { (mL/min) }\end{array}$ & Ho (inch) & Hn (inch) & Cyst Count \\
\hline $\begin{array}{c}\text { Raw } \\
\text { Water }\end{array}$ & 0 & 53.6 & 0 & 0 & 0 & 0 & \#DIV/0! & 0 & & 38.50 & TNTC \\
\hline Pre-Filter & 0 & 6.76 & 0 & & & & & & & & \\
\hline & 2 & 5.90 & 2 & 2000 & 209 & 3.483 & 0.00957 & 574.16 & 38.50 & 36.50 & \\
\hline Pre-Filter & 4 & 6.58 & & & & & & & & & TNTC \\
\hline & 4 & 5.92 & 2 & 2000 & 217 & 3.617 & 0.00922 & 553.00 & 36.50 & 34.75 & 3074 \\
\hline & 6 & 5.87 & 2 & 2000 & 144 & 2.400 & 0.01389 & 833.33 & 34.75 & 31.50 & \\
\hline & 8 & 5.70 & 2 & 2000 & 190 & 3.167 & 0.01053 & 631.58 & 31.50 & 26.00 & \\
\hline
\end{tabular}

\section{EXPERIMENT G-3}


In --> Out 2 Ply Nominal Filter, 15 Min. Mix in 5 Min. Bag - Run 1 PUR Serial \#: $0015032231 \quad$ Mfg. 1/10 Exp: 12/12

Recipe: tap water, dust, I.0., humic, and spheres (15 L)

Water Temp: 22oC

\begin{tabular}{|c|c|c|c|c|c|c|c|c|c|c|c|}
\hline Water & $\begin{array}{l}\text { Total Vol. } \\
\text { Filtered (L) }\end{array}$ & $\begin{array}{c}\text { Turbidity } \\
\text { (NTU) }\end{array}$ & $\begin{array}{l}\text { Vol. of Water } \\
\text { Discharged (L) }\end{array}$ & $\begin{array}{l}\text { Volume of } \\
\text { Water }(\mathrm{mL})\end{array}$ & Time (sec) & Time (min) & $\begin{array}{l}\text { Flowrate } \\
\text { (L/sec) }\end{array}$ & $\begin{array}{l}\text { Flowrate } \\
\text { (mL/min) }\end{array}$ & Ho (inch) & Hn (inch) & Cyst Count \\
\hline $\begin{array}{c}\text { Raw } \\
\text { Water }\end{array}$ & 0 & 55.1 & 0 & 0 & 0 & 0 & $\# D I V / O$ ! & 0 & & 39.25 & $\mathrm{~N} / \mathrm{M}$ \\
\hline \multirow[t]{2}{*}{ Pre-Filter } & 0 & 5.45 & 0 & & & & & & & & \\
\hline & 2 & 4.32 & 2 & 2000 & 163 & 2.717 & 0.01227 & 736.20 & 39.25 & 37.50 & \\
\hline \multirow[t]{4}{*}{ Pre-Filter } & 4 & 5.26 & & & & & & & & & $N / M$ \\
\hline & 4 & 4.18 & 2 & 2000 & 189 & 3.150 & 0.01058 & 634.92 & 37.50 & 35.75 & $\mathrm{~N} / \mathrm{M}$ \\
\hline & 6 & 3.97 & 2 & 2000 & 165 & 2.750 & 0.01212 & 727.27 & 35.75 & 29.50 & \\
\hline & 8 & 4.11 & 2 & 2000 & 259 & 4.317 & 0.00772 & 463.32 & 29.50 & 31.75 & \\
\hline
\end{tabular}

In --> Out 2 Ply Nominal Filter, 15 Min. Mix in 10 Min. Bag - Run 2

PUR Serial \#: 0015032231 Mfg. 1/10 Exp: 12/12

Recipe: tap water, dust, I.0., humic, and spheres (15 L)

Water Temp: 21.5oC

\begin{tabular}{|c|c|c|c|c|c|c|c|c|c|c|c|}
\hline Water & $\begin{array}{l}\text { Total Vol. } \\
\text { Filtered (L) }\end{array}$ & $\begin{array}{l}\text { Turbidity } \\
\text { (NTU) }\end{array}$ & $\begin{array}{l}\text { Vol. of Water } \\
\text { Discharged (L) }\end{array}$ & $\begin{array}{l}\text { Volume of } \\
\text { Water }(\mathrm{mL})\end{array}$ & Time $(\mathrm{sec})$ & Time (min) & $\begin{array}{c}\text { Flowrate } \\
\text { (L/sec) }\end{array}$ & $\begin{array}{l}\text { Flowrate } \\
\text { (mL/min) }\end{array}$ & Ho (inch) & Hn (inch) & Cyst Count \\
\hline $\begin{array}{c}\text { Raw } \\
\text { Water }\end{array}$ & 0 & 52.1 & 0 & 0 & 0 & 0 & \#DIV/O! & 0 & & 37.50 & $\mathrm{~N} / \mathrm{M}$ \\
\hline \multirow[t]{2}{*}{ Pre-Filter } & 0 & 5.11 & 0 & & & & & & & & \\
\hline & 2 & 4.53 & 2 & 2000 & 186 & 3.100 & 0.01075 & 645.16 & 37.50 & 34.00 & \\
\hline \multirow[t]{4}{*}{ Pre-Filter } & 4 & 5.09 & & & & & & & & & $\mathrm{~N} / \mathrm{M}$ \\
\hline & 4 & 4.58 & 2 & 2000 & 258 & 4.300 & 0.00775 & 465.12 & 34.00 & 31.00 & $\mathrm{~N} / \mathrm{M}$ \\
\hline & 6 & 1.56 & 2 & 2000 & 213 & 3.550 & 0.00939 & 563.38 & 31.00 & 27.50 & \\
\hline & 8 & 4.61 & 2 & 2000 & 174 & 2.900 & 0.01149 & 689.66 & 27.50 & 23.25 & \\
\hline
\end{tabular}

\section{EXPERIMENT H-1}

\begin{tabular}{|c|c|c|c|c|c|c|c|c|c|c|}
\hline \multicolumn{11}{|c|}{ In $-->$ Out 1 Ply Nominal Filter, 5 Min. Mix - Run 1} \\
\hline PUR Serial & 0015032 & 31 Mfg. 1/ & Exp: 12 & & & & & & & \\
\hline \multicolumn{11}{|c|}{ Recipe: tap water, dust, I.O., humic, and spheres (15 L) } \\
\hline \multicolumn{11}{|c|}{ Water Temp: $230 \mathrm{C}$} \\
\hline Water & $\begin{array}{l}\text { Total Vol. } \\
\text { Filtered (ㄴ) }\end{array}$ & Turbidity (NTU) & $\begin{array}{l}\text { Vol. of Water } \\
\text { Discharged (ㄴ) }\end{array}$ & $\begin{array}{l}\text { Volume of } \\
\text { Water }(\mathrm{mL})\end{array}$ & Time $[\mathrm{sec}]$ & Time $(\min )$ & $\begin{array}{l}\text { Flowrate } \\
\text { (L/sec) }\end{array}$ & $\begin{array}{l}\text { Flowrate } \\
\text { (mL/min) }\end{array}$ & Ho (inch) & Hn (inch) \\
\hline Raw Water & 0 & 51.3 & 0 & 0 & 0 & 0 & \#DIV/0! & 0 & & 37.75 \\
\hline \multirow[t]{2}{*}{ Pre-Filter } & 0 & 7.59 & 0 & & & & & & & \\
\hline & 2 & 3.80 & 2 & 2000 & 175 & 2.917 & 0.01143 & 685.71 & 37.75 & 33.25 \\
\hline \multirow[t]{4}{*}{ Pre-Filter } & 4 & 3.70 & & & & & & & & \\
\hline & 4 & 3.68 & 2 & 2000 & 155 & 2.583 & 0.01290 & 774.19 & 33.25 & $\mathrm{~N} / \mathrm{M}$ \\
\hline & 6 & 3.39 & 2 & 2000 & 207 & 3.450 & 0.00966 & 579.71 & $\mathrm{~N} / \mathrm{M}$ & \begin{tabular}{|r|}
27.50 \\
\end{tabular} \\
\hline & 8 & 3.51 & 2 & 2000 & 216 & 3.600 & 0.00926 & 555.56 & $\begin{array}{r}27.50 \\
\end{array}$ & 23.50 \\
\hline Notes: & & & & & & & & & & \\
\hline
\end{tabular}




\section{EXPERIMENT H-2}

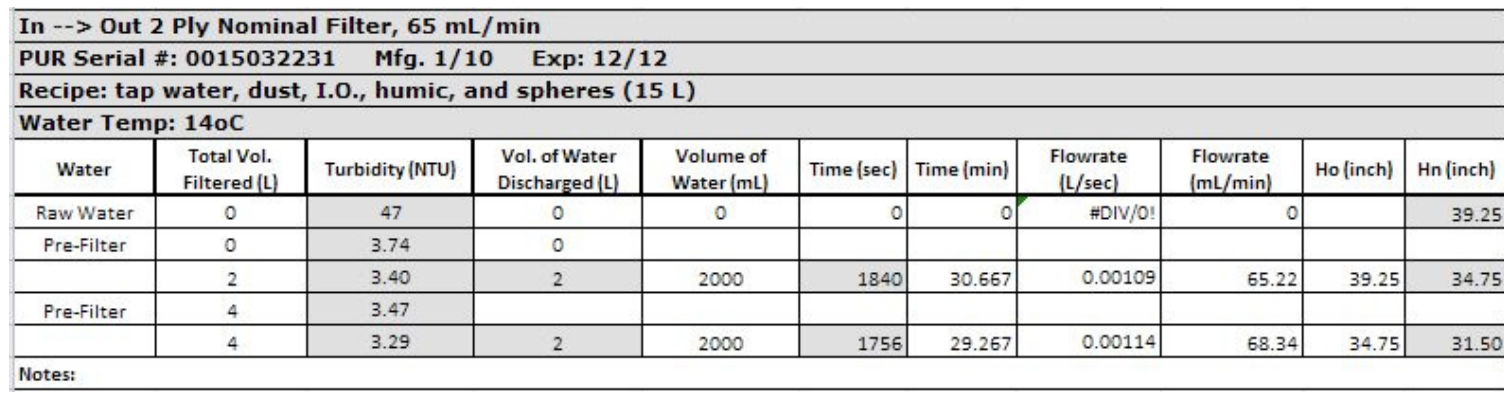

\section{EXPERIMENT H-3 (50 mL/min)}

\begin{tabular}{|c|c|c|c|c|c|c|c|c|c|c|c|}
\hline \multicolumn{12}{|c|}{ In $-\rightarrow$ Out 2 Ply Nom.-Abs. Filter, 50-mL/min } \\
\hline \multicolumn{12}{|c|}{ Recipe: tap water, dust, I.0., humic, and spheres (15 L) } \\
\hline \multicolumn{12}{|c|}{ Water Temp: $140 \mathrm{C}$} \\
\hline Water & $\begin{array}{l}\text { Total Vol. } \\
\text { Filtered (L) }\end{array}$ & & bidity (NTU) & $\begin{array}{l}\text { Vol. of Water } \\
\text { Discharged (L) }\end{array}$ & $\begin{array}{l}\text { Volume of } \\
\text { Water }(\mathrm{mL})\end{array}$ & Time $(\mathrm{sec})$ & Time (min) & $\begin{array}{c}\text { Flowrate } \\
\text { (L/sec) }\end{array}$ & $\begin{array}{l}\text { Flowrate } \\
(\mathrm{mL} / \mathrm{min})\end{array}$ & Ho (inch) & Hn (inch) \\
\hline Raw Water & 0 & & 49.4 & 0 & 0 & 0 & 0 & \#DIV/O! & 0 & & 64.50 \\
\hline \multirow[t]{2}{*}{ Pre-Filter } & 0 & & 2.11 & 0 & & & & & & & \\
\hline & 2 & & 0.88 & 2 & 2000 & 1386 & 23.100 & 0.00144 & 86.58 & 64.50 & 61.25 \\
\hline \multirow[t]{2}{*}{ Pre-Filter } & 4 & & 1.95 & & & & & & & & \\
\hline & 4 & & 0.85 & 2 & 2000 & 3009 & 50.150 & 0.00066 & 39.88 & 61.25 & 58.00 \\
\hline
\end{tabular}

\begin{tabular}{|c|c|c|c|c|c|c|c|c|c|c|c|}
\hline \multicolumn{12}{|c|}{ In $-\rightarrow$ Out 2 Ply Nom.-Abs. Filter, $50-\mathrm{mL} / \mathrm{min}$} \\
\hline PUR Serial & 9289032 & & Mfg. & xp: & & & & & & & \\
\hline \multicolumn{12}{|c|}{ Recipe: tap water, dust, I.O., humic, and spheres (15 L) } \\
\hline \multicolumn{12}{|c|}{ Water Temp: $110 \mathrm{C}$} \\
\hline Water & $\begin{array}{l}\text { Total Vol. } \\
\text { Filtered (L) }\end{array}$ & & bidity (NTU) & $\begin{array}{l}\text { Vol. of Water } \\
\text { Discharged (Lᄂ) }\end{array}$ & $\begin{array}{l}\text { Volume of } \\
\text { Water }(\mathrm{mL})\end{array}$ & Time $(\mathrm{sec})$ & Time (min) & $\begin{array}{c}\text { Flowrate } \\
\text { (L/sec) }\end{array}$ & $\begin{array}{l}\text { Flowrate } \\
(\mathrm{mL} / \mathrm{min})\end{array}$ & Ho (inch) & Hn (inch) \\
\hline Raw Water & 0 & & 48.9 & 0 & 0 & 0 & 0 & \#DIV/O! & 0 & & 65.00 \\
\hline \multirow[t]{2}{*}{ Pre-Filter } & 0 & & 4.66 & 0 & & & & & & & \\
\hline & 2 & & 2.70 & 2 & 2000 & 2378 & 39.633 & 0.00084 & 50.46 & 65.00 & 62.00 \\
\hline \multirow[t]{2}{*}{ Pre-Filter } & 4 & & 3.88 & & & & & & & & \\
\hline & 4 & & 2.90 & 2 & 2000 & 2383 & 39.717 & 0.00084 & 50.36 & 62.00 & 59.00 \\
\hline
\end{tabular}

\section{EXPERIMENT H-3 (20 mL/min)}

\begin{tabular}{|c|c|c|c|c|c|c|c|c|c|c|c|}
\hline \multicolumn{12}{|c|}{ In $-\rightarrow$ Out 2 Ply Nom.-Abs. Filter, 20- $\mathrm{mL} / \mathrm{min}$ and port screen } \\
\hline PUR Serial & 9289032 & & Mfg. & Exp: & & & & & & & \\
\hline \multicolumn{12}{|c|}{ Recipe: tap water, dust, I.O., humic, and spheres (15 L) } \\
\hline \multicolumn{12}{|c|}{ Water Temp: $9 \mathrm{oC}$} \\
\hline Water & $\begin{array}{l}\text { Total Vol. } \\
\text { Filtered (니 }\end{array}$ & & bidity (NTU) & $\begin{array}{l}\text { Vol. of Water } \\
\text { Discharged (니) }\end{array}$ & $\begin{array}{l}\text { Volume of } \\
\text { Water }(\mathrm{mL})\end{array}$ & Time $(\mathrm{sec})$ & Time $(\mathrm{min})$ & $\begin{array}{c}\begin{array}{c}\text { Flowrate } \\
\text { (L/sec) }\end{array} \\
\end{array}$ & $\begin{array}{l}\text { Flowrate } \\
\text { (mL/min) }\end{array}$ & Ho (inch) & Hn (inch) \\
\hline Raw Water & 0 & & 46.5 & 0 & 0 & 0 & 0 & \#DIV/0! & 0 & & 65.00 \\
\hline \multirow[t]{2}{*}{ Pre-Filter } & 0.1 & & 2.64 & 0 & & & & & & & \\
\hline & 2 & & 1.17 & 2 & 2000 & 5700 & 95.000 & 0.00035 & 21.05 & 65.00 & 63.00 \\
\hline \multirow[t]{2}{*}{ Pre-Filter } & 4 & & 2.28 & & & & & & & & \\
\hline & 4.1 & & 1.13 & 2 & 2000 & 5940 & 99.000 & 0.00034 & 20.20 & 63.00 & 61.00 \\
\hline
\end{tabular}


In $\rightarrow$ Out 2 Ply Nom.-Abs. Filter, $20-\mathrm{mL} / \mathrm{min}$ and port screen

PUR Serial \#: 9289032230 Mfg. Exp:

Recipe: tap water, dust, I.0., humic, and spheres (15 L)

Water Temp: 9.5oC

\begin{tabular}{|c|c|c|c|c|c|c|c|c|c|c|}
\hline Water & $\begin{array}{l}\text { Total Vol. } \\
\text { Filtered (L) }\end{array}$ & Turbidity (NTU) & $\begin{array}{l}\text { Vol. of Water } \\
\text { Discharged (L) }\end{array}$ & $\begin{array}{l}\text { Volume of } \\
\text { Water }(\mathrm{mL})\end{array}$ & Time $(\mathrm{sec})$ & Time (min) & $\begin{array}{c}\text { Flowrate } \\
\text { (L/sec) }\end{array}$ & $\begin{array}{l}\text { Flowrate } \\
\text { [mL/min) }\end{array}$ & Ho (inch) & Hn (inch) \\
\hline Raw Water & 0 & 48.9 & 0 & 0 & 0 & 0 & \#DIV/O! & 0 & & 65.25 \\
\hline \multirow[t]{2}{*}{ Pre-Filter } & 0.1 & 2.31 & 0 & & & & & & & \\
\hline & 2 & 1.38 & 2 & 2000 & 5970 & 99.500 & 0.00034 & 20.10 & 65.25 & 62.00 \\
\hline \multirow[t]{2}{*}{ Pre-Filter } & 4 & 2.18 & & & & & & & & \\
\hline & 4.1 & 1.31 & 2 & 2000 & 5740 & 95.667 & 0.00035 & 20.91 & 62.00 & 59.50 \\
\hline
\end{tabular}




\section{APPENDIX D: BIOVIR REPORT (2012)}

Test report from BioVir Laboratories, Inc. for experiment I-1, performed August 17, 2012. 
BioVir Laboratories, Inc.

685 Stone Road, Unit $6 \bullet$ Benicia, CA $94510 \bullet$ (707) 747-5906 •1-800-GIARDIA • FAX (707) 747-1751 • WEB: www.biovir.com

TEST REPORT

\begin{tabular}{|l|l|}
\hline Project Title & Polytech Waterbag Challenge \\
\hline Project No. & 121132 \\
\hline Sponsor: & Cal Poly Corporation \\
\hline C/O: & $\begin{array}{l}\text { Prof. Tryg Lundquist } \\
\text { California Polytechnic State University } \\
\text { Civil \& Environmental Engineering Department } \\
\text { San Luis Obispo, CA 93407 }\end{array}$ \\
\hline Date: & September 6, 2012 \\
\hline From: & Robert C. Cooper, VP \\
\hline
\end{tabular}

Introduction: The Cal Poly Corp contracted with BioVir Laboratories to perform microbiological challenges of the Polytech Waterbag device being developed by Professor Lundquist and his students. Three bags were challenged with the bacterium Esherichia coli (ATCC11229), two coliphage types (MS2 ATCC 15597-B1) and fr (ATCC15767-B1) and with 3.1 $\mu \mathrm{m}$ diameter fluorescent microspheres as a surrogate for Cryptosporidium oocysts (Duke Scientific Corp, Palo Alto, CA.) On August 17, 2012 Professor Lundquist and two graduate students arrived at BioVir Labs with three test bags and the necessary ancillary equipment needed to operate the treatment units.

The challenge water (40L of Test water \#2) was prepared by BioVir staff and had the quality shown in Table 1 below:

\begin{tabular}{|l|l|}
\hline \multicolumn{2}{|l|}{ Table 1. Challenge Water \#2 } \\
\hline \hline Parameter & Value- \\
\hline \hline Volume & $40 \mathrm{~L}$ \\
\hline $\mathrm{pH}$ & 9.1 \\
\hline Chlorine & ND Non Detect \\
\hline TDS & $1450 \mathrm{mg} / \mathrm{L}$ \\
\hline NTU & $33^{*}$ \\
\hline TOC & $12.6 \mathrm{mg} / \mathrm{L}$ \\
\hline Temperature & $4^{\circ} \mathrm{C}$ \\
\hline *Before Humic acid added \\
\hline
\end{tabular}

Just prior to the challenge the test water was inoculated with the challenge microorganisms and 
microspheres. The seed microorganisms were prepared as per standard BioVir protocols. The test water was constantly mixed using a magnetic stirring device. Each bag was filled with $10 \mathrm{~L}$ of the seeded test water at which point the Cal Poly group performed the treatment operation. The product water from each unit. produced over time, was collected into10L cubitainers and a sub-sample of one $L$ taken from each of the cubitainers at the end of the test run. The one liter sample was collected in sterile bottles containing enough sterile sodium thiosulfate to neutralize any residual disinfectant that might be present in the sample. A one liter influent sample) was collected from the $40 \mathrm{~L}$ seed reservoir.

The influent and product water samples were kept refrigerated until assayed, with the exceptio of the micrspheres, a period of no more than 3 hours. The E.coli assays were performed using the membrane filter method and employing mFC agar incubated for 20 to 24 hours at $45^{\circ} \mathrm{C}$; the results being reported a colony forming units (Cfu) per $\mathrm{mL}$. The combined bacterophage were assayed using the Adams double agar overlay method and reported as plaque forming units $(\mathrm{Pfu})$ per $\mathrm{mL}$. The microspheres were enumerated by direct microscopic count using epi-fluorescent microscopy and reported as spheres per $\mathrm{L}$.

Results: The results of the challenged are shown in the following Tables.

\begin{tabular}{|l|l|l|l|l|l|l|}
\hline \multicolumn{3}{|l|}{ Table 2. E.coli Results Cfu/ $100 \mathrm{~mL}$} \\
\hline \multirow{3}{*}{ Influent } & \multicolumn{2}{|l|}{ Test Unit \#1 } & \multicolumn{2}{|l|}{ Test Unit \#2 } & \multicolumn{2}{l|}{ Test Unit \#3 } \\
\cline { 2 - 7 } & $\begin{array}{l}\text { Bag } \\
\text { Effluent }\end{array}$ & $\begin{array}{l}\text { Post Filter } \\
\text { Effluent }\end{array}$ & $\begin{array}{l}\text { Bag } \\
\text { Effluent }\end{array}$ & $\begin{array}{l}\text { Post Filter } \\
\text { Effluent }\end{array}$ & $\begin{array}{l}\text { Bag } \\
\text { Effluent }\end{array}$ & $\begin{array}{l}\text { Post Filter } \\
\text { Effluent }\end{array}$ \\
\hline $7.3 \times 10^{6}$ & $<1$ & $<1$ & $<1$ & $<1$ & $1.5 \times 10^{4}$ & $2.2 \times 10^{2}$ \\
\hline $\begin{array}{l}\text { Log } \\
\text { Reduction } \\
:\end{array}$ & \multicolumn{2}{|c|}{$>6.7$} & 2.6 & 4.5 \\
\hline
\end{tabular}

Table 3. Coliphage Results Pfu/ $\mathrm{mL}$

\begin{tabular}{|l|l|l|l|l|l|l|}
\hline \multirow{2}{*}{ Influent } & \multicolumn{2}{|l|}{ Test Unit \#1 } & \multicolumn{2}{l|}{ Test Unit \#2 } & \multicolumn{2}{l|}{ Test Unit \#3 } \\
\cline { 2 - 7 } & $\begin{array}{l}\text { Bag } \\
\text { Effluent }\end{array}$ & $\begin{array}{l}\text { Post Filter } \\
\text { Effluent }\end{array}$ & $\begin{array}{l}\text { Bag } \\
\text { Effluent }\end{array}$ & $\begin{array}{l}\text { Post Filter } \\
\text { Effluent }\end{array}$ & $\begin{array}{l}\text { Bag } \\
\text { Effluent }\end{array}$ & $\begin{array}{l}\text { Post Filter } \\
\text { Effluent }\end{array}$ \\
\hline $1.3 \times 10^{5}$ & $<1$ & $<1$ & $<1$ & $<1$ & 9 & 4 \\
\hline $\begin{array}{l}\text { Log } \\
\text { Reduction: }\end{array}$ & \multicolumn{2}{|c|}{$>5.1$} & \multicolumn{2}{|c}{$\geq 4.3$} \\
\hline
\end{tabular}

\begin{tabular}{|c|c|c|c|c|c|c|}
\hline \multirow{2}{*}{ Influent } & \multicolumn{2}{|c|}{ Test Unit \#1 } & \multicolumn{2}{|c|}{ Test Unit \#2 } & \multicolumn{2}{|c|}{ Test Unit \#3 } \\
\hline & $\begin{array}{l}\text { Bag } \\
\text { Effluent }\end{array}$ & $\begin{array}{l}\text { Post Filter } \\
\text { Effluent }\end{array}$ & $\begin{array}{l}\text { Bag } \\
\text { Effluent }\end{array}$ & $\begin{array}{l}\text { Post Filter } \\
\text { Effluent }\end{array}$ & $\begin{array}{l}\text { Bag } \\
\text { Effluent }\end{array}$ & $\begin{array}{l}\text { Post Filter } \\
\text { Effluent }\end{array}$ \\
\hline $5.6 \times 10^{5}$ & $7.7 \times 10^{3}$ & $<50 / \mathrm{L}$ & $7.0 \times 10^{3}$ & $1.2 \times 10^{2}$ & $4.4 \times 10^{3}$ & $2.2 \times 10^{3}$ \\
\hline $\begin{array}{l}\text { Log } \\
\text { Reduction: }\end{array}$ & 1.9 & $>4.1$ & 1.9 & 3.7 & 2.1 & 2.4 \\
\hline
\end{tabular}

